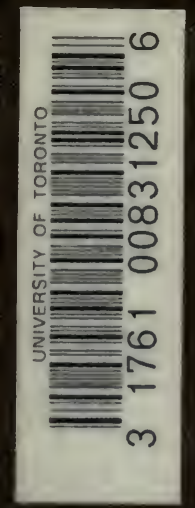

THE

GAELIC NAMES

OF PLANTS

CAMERON 


[arly exthir
25t 
GAELIC NAMES OF PLANTS 
"I study to bring forth some acceptable work: not striving to shew any rare invention that passeth a man's capacity, but to utter and receive matter of some monent known and talked of long ago, yet over long hath been buried, and, as it seemed, lain dead, for any fruit it hath shewed in the memory of man."-Churchward, 588. 


\title{
GAELIC NAMES OF PLANTS
}

\author{
(SCOTTISH AND IRISH)
}

COLLECTED AND ARRANGED IN SCIENTIFIC ORDER, WITH NOTES ON THEIR ETYMOLOGY, THEIR USES, PLANT SUPERSTITIONS, ETC., AMONG THE CELTS, WITH COPIOUS GAELIC, ENGLISH, AND SCIENTIFIC INDICES

\section{JOHN $\underset{\substack{\text { CII } \\ \text { SUNDERLAND }}}{\text { CAMORON }}$}

"What's IN a NAME? That Which WE CALl A ROSE By ANY OTHER NAME WOULd SMELl AS SWEet."

-Shakespeare.

WILLIAM BLACKWOOD AND SONS EDINBURGH AND LONDON MDCCCLXXXIII 
3149 :1

gislielirili

llislit.1960? $\frac{636578}{4.6 .56}$

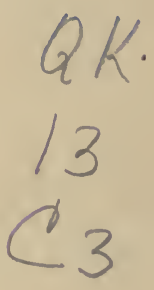

13

$C_{3}$ 
To

\section{J. BUCHANAN WHITE, M.D., F.L.S.}

WHOSE LIFE HAS BEEN DEVOTED TO

NATURAL SCIENCE,

AT WHOSE SUGGESTION THIS

COllection of GaEliC NAMES OF Plants

WAS UNDERTAKEN,

\section{This Tark}

IS RESPECTFULLY INSCRIBED BY

THE AUTHOR. 
Digitized by the Internet Archive in 2008 with funding from Microsoft Corporation 


\section{P R E F A C E.}

THE Gaelic Names of Plants, reprinted from a series of articles in the 'Scottish Naturalist,' which have appeared during the last four years, are published at the request of many who wish to have them in a more convenient form. There might, perhaps, be grounds for hesitation in obtruding on the public a work of this description, which can only be of use to comparatively few ; but the fact that no book exists containing a complete catalogue of Gaelic names of plants is at least some excuse for their publication in this separate form. Moreover, it seemed to many able botanists that, both for scientific and philological reasons, it would be very desirable that an attempt should be made to collect such names as are still used in the spoken Gaelic of Scotland and Ireland, before it became too late by the gradual disappearance of the language. Accordingly the author undertook this task at the request of the Editor of the 'Scottish Naturalist,' Dr Buchanan White, F.L.S. If the difficulties of its accomplishment had been foreseen, he would have hesitated to make the attempt; as it is, nearly ten years of his life have been occupied in searching through vocabularies, reading Irish and Scottish Gaelic, and generally trying to bring into order the confusion to which these names have been reduced partly by the carelessness of the compilers of Dictionaries, and frequently by their botanical ignorance. To accomplish this, numerous journeys had to be undertaken among 
the Gaelic-speaking populations, in order, if possible, to settle disputed names, to fix the plant to which the name was applied, and to collect others previousiy unrecorded.

In studying the Gaelic nomenclature of plants, it soon became evident that no collection would be of any value unless the Irish-Gaelic names were incorporated. Indeed, when the lists supplied by Alexander M'Donald (MacMhaighister-Alastair), published in his vocabulary in I74I, are examined, they are found to correspond with those in much older vocabularies published in Ireland. The same remark applies, with a few exceptions, to the names of plants in Gaelic supplied by the Rev. Mr Stewart of Killin, given in Lightfoot's 'Flora Scotica.' Undoubtedly, the older names have been preserved in the more copious Celtic literature of Ireland; it is certainly true that "In vetustâ Hibernicâ fundamentum luabet." The investigations of Professor O'Curry, O'Donovan, and others, have thrown much light on this as well as upon many other Celtic topics. The Irish names are therefore included, and spelt according to the various methods adopted by the different authorities; this gives the appearance of a want of uniformity to the spelling not altogether agreeable to Gaelic scholars, but which, under the circumstances, was unavoidable.

It was absolutely essential that the existing Gaelic names should be assigned correctly. The difficulty of the ordinary botanical student was here reversed: he has the plant but cannot tell the name-here the name existed, but the plant required to be found to which the name applied. Again, names had been altered from their original form by transcription and pronunciation; it became a matter of difficulty to determine the root word. However, the recent progress of philology, the knowledge of the laws that govern the modifications of words in the brotherhood of European languages, when applied to these names, rendered the explanation given not altogether improbable. Celts named plants often from (I), their uses ; (2), their appearance ; (3), their habitats ; (4), 
their superstitious associations, \&c. The knowledge of this habit of naming was the key that opened many a difficulty.

For the sake of comparison a number of Welsh names is given, selected from the oldest list of names obtainable, - those appended to Gerard's 'Herbalist,' 1597.

The author cannot sufficiently express his obligation to numerous correspondents in the Highlands and in Ireland for assistance in gathering local names; without such help it would have been impossible to make a complete collection. Notably the Rev. A. Stewart, Nether Lochaber, whose knowledge of natural history is unsurpassed in his own sphere; the Very Rev. Canon Bourke, Claremorris, who gave most valuable assistance in the Irish names, particularly in the etymology of many abstruse terms, his accurate scholarship, Celtic and classical, helping him over many a difficulty; $\mathrm{Mr}$ W. Brockie, an excellent botanist and philologist, who some years ago made a collection of Gaelic names of plants which was unfortunately destroyed, placed at the author's disposal valuable notes and information relative to this subject; and lastly, the accomplished Editor of the 'Scottish Naturalist,' who, from its commencement, edited the sheets and secured the correct scientific order of the whole.

With every desire to make this work as free from errors as possible, yet, doubtless, some have escaped attention; therefore, any names omitted, any mistake in the naming of the plants, or any other fact tending towards the further elucidation of this subject will be thankfully received for future addition, correction, or amendment.

\section{JOHN CAMERON.}

SUNDERLAND, Fanuary 1883. 



\section{THE GAELIC NAMES OF PLANTS.}

\section{Ranunculacee.}

Thalictrum-( $\theta a \lambda \lambda \omega$, thallo, to grow green). Gaelic: rugh, riu, ruigh,
Irish : ruib, graveolens). See Gerard.

T. alpinum.-Rí ailpeach: Alpine meadow-rue.

T. minus. - R $\imath$ beg: Lesser meadow-rue. RUE is nearly the same in most of the ancient languages; said to be from $\rho v \omega$, to flow; Gaelic - ruith, flow, rush; their roots, especially T. flavum, possessing powerful cathartic qualities like rhubarb. Compare also ru, run, a secret, mystery, love, desire, grace. Welsh : runa, hieroglyphics (Runic). The Thalictrum of Pliny is supposed to be the meadoze-rue. (See Freund's Lexicon.)

"I'll set a bank of rue, sour herb of grace"-Shakespeare.

"Mo rim geal og !"-My fair young beloved one !

"Oir a ta sibh a toirt deachaimh 'a mionnt, agus a rì, agùs gach uile ghnè luibhean."-For ye tithe mint and rue, and all manner of herbs.

The Rue of Shakespeare is generally supposed to be Ruta graveolens ( $R$ i gharaidh), a plant belonging to another order, and not indigenous.

Anemone nemorosa-Wind-flower. Gaelic : plìr na gaoithe, wind-flower (Armstrong). Welsh : llysiau'r gzoynt, wind-flower, because some of the species prefer windy habitats. Irish : nead chailleach, old woman's nest.

Ranunculus.-From Gaelic, ran; Egyptian, ranah; Latin, rana, a frog, because some of the species inhabit humid places frequented by that animal, or because some of the plants have leaves resembling in shape a frog's foot. Ranunculus is also 
sometimes called crowfoot. Gaelic: cearban, raggy, from its divided leaves. Gair-cean,-from gair, a smile ; cean, love, elegance. Welsh : crafrange y frân, crows' claws.

R. aquatilis-Water crowfoot. Gaelic: fleann uisge, probably from lean, to follow, and uisge, water, follower of the water. Lion na l'aibhne, the river-flax. Irish : neul uisge,-neul, a star, and uisge, water. Tuir chis,-tuir, a lord; chis, purse (from its numerous achenes).

R. ficaria-Lesser celandine. Gaelic : grain-aigein, that which produces loathing. Searraiche, a little bottle, from the form of the roots. Welsh : toddedig zeen, fire dissolvent; toddi, melt, dissolve.

R. flammula - Spearwort. Gaelic: glas-leun,-glas, green; leun, a swamp. Lasair-leana,-lasair, a flame, and leana or leun, a swamp, a spear. Welsh : blaer y guaez, lance-point.

R. auricomus - Goldilocks. Gaelic: follasgain; probably from follais, conspicuous. Irish: foloscain, a tadpole. The Gaelic may be a corruption from the Irish, or vice versa; also gruag Mhuire, Mary's locks.

R. repens-Creeping crowfoot. Gaelic: buigheag, the yellow one. Irish: bairgin, more frequently bairghin, a pilgrim's habit. Fearban,-fearba, killing, destroying.

R. acris-Upright meadow crowfoot. Gaelic : cearban feoir, the grass rag. Irish: the same name. This plant and $R$. flammula are used in the Highlands, applied in rags (cearban), for raising blisters.

R. bulbosus-Bulbous crowfoot. Gaelic: fuile thalmhainn, blood of the earth (it exhausts the soil). Welsh: crafange $y$ frân, crows' claws.

R. sceleratus - Celery-leaved crowfoot. Gaelic and Irish: torachas biadhain; probably means food of which one would be afraid.

Caltha palustris-Marsh-marigold. Gaelic : a chorrach shod, the clumsy one of the marsh. Lus bhuidhe bealtuinn, the yellow plant of Beltane or May,-Bel or Baal, the sun-god, and teine, fire. The name survives in many Gaelic names-e.g., Tullibeltane, the high place of the fire of Baal.

\footnotetext{
"Beath a's calltuinn latha-bealthuinn."-M'KAY.

Birch and hazel first day of May.
}

Irish: plubairsin from plubrach, plunging. Lus Mairi, Marywort, Marygold. 
Helleborus viridis - Green hellebore. Gaelic : elebor, a corruption of helleborus (from the Greek $\epsilon^{\lambda} \epsilon \omega \mathrm{v}$, helein, to cause death; and $\beta$ opa, bora, food-poisonous food).

"Mo shròn tha stocpt à dh'elebor."-M'DonalD.

My nose is stopped with hellebore.

H. fœetidus - Stinking hellebore. Meacan sleibhe, the hillplant.

Aquilegia vulgaris-Columbine. Gaelic: lus a cholamain, the dove's plant. Irish : cruba-leisin,-from cruba, crouching, and leise, thigh or haunch; suggested by the form of the flower. Lusan cholam (O'Reilly), pigeon's flower. Welsh: troed $y$ glomen, naked woman's foot.

Aconitum napellus-Monkshood. Gaelic: fuath mhadhaidh (Shaw), the wolf's aversion. Curaichd mhannaich (Armstrong), monkshood. Welsh: bleiddag,-from bleidd, a wolf, and $\mathrm{tag}$, choke.

Nigella damascena-Chase-the-devil. Gaelic: lus an fhograidh, the pursued plant. Irish : lus mhic Raonail, MacRonald's wort. Not indigenous, but common in gardens.

Pæonia officinalis-Peony. Gaelic: lus a phione. A corruption of Pcon, the physician who first used it in medicine, and cured Plato of a wound inflicted by Hercules. Welsh : bladeu'r brenin, the king's flower. Irish : lus phoinc.

\section{BERBERIDACE $Æ$.}

Berberis vulgaris-Barberry. Gaelic : barbrag (a corruption from Phoenician word barar), the brilliancy of a shell; alluding to their shining leaves. Greek $\beta \epsilon \rho \beta \epsilon \rho$, berberi, a shell. Preas nan gear dhearc, the sour berry-bush. Preas deilgneach, the prickly bush. Irish : barbrog.

\section{NYMPHÆACE.⿻.}

(From $v v \mu \phi \eta, n y m p h e$, a water-nymph, referring to their habitats.)

Nymphæa alba-White water-lily. Gaelic: duileag bhaite $b h a n$, the drowned white leaf.

"Feur lochain is tachair,

An cinn an duileag bhaite."-M'INTYRE.

Water, grass, and algre,

Where the water-lily grows.

"O lili, righ nam fleuran."-M'Donaln.

O lily, king of flowers. 
Rabhagach, giving caution or warning; a beacon. Lili bhàn, white lily. Welsh : Lili-r-drefr, water-lily. Irish : buillite. (Shaw.)

Nuphar luteum -Yellow water-lily. Gaelic: duileag bhaite bhuidhe, the yellow drowned leaf. Lili bhuidhe n'uisge, yellow water-lily. Irish : liach laghor, the bright flag. Cabhan abhain,cabhan, a hollow plain, and abhain, of the river.

\section{Papaveracee.}

Papaver rhœas - Poppy. Gaelic : meilbheag, sometimes beilbheag, a little pestle (to which the capsule has some resemblance).

"Le meillheag, le noinean, 's le slan-lus."-M'LeOD.

With a poppy, daisy, and rib-grass.

Fothros, corn-rose,--from ioth (Irish), corn; ros, rose. Cromlus, bent weed. Paipean ruadh, - ruadh, red, and paipean a corruption of papaver, from $p a p a$, pap, or pappo, to eat of pap. The juice was formerly put into children's food to make them sleep. Welsh : pabi.

P. somniferum-Common opium poppy. Gaelic: codalian, from codal or cadal, sleep.

Chelidonium majus. Common celandine (a corruption of $\chi \epsilon \lambda \iota \delta \omega v$, chelidon, a swallow). Gaelic: an ceann ruadh, ${ }^{1}$ the red head. Irish : lacha cheann ruadh, the red-headed duck. Welsh : llysic y wennol, swallow-wort. The flower is yellow, not red. Aonsgoch is another Gaelic name for swallow-wort, meaning the lonely flower,-aon, one or alone, and sgoth, a flower.

Glaucium luteum - Yellow horned poppy. Gaelic: barrag ruadh (?), the valiant or strong head. The flower is yellow, not red.

\section{FumARIACEE.}

(From fumus, smoke. "The smoke of these plants being said by the ancient exorcists to have the power of expelling evil spirits" (Jones). French : fume terre.)

Fumaria officinalis - Fumitory. Gaelic: lus deathach thatmhainn (Armstrong), the earth-smoke plant. Irish: deatach thalmhuin (O'Reilly), earth-smoke. Welsh: meg y ddaer, earth-smoke. Another Irish name is caman scarraigh (O'Reilly), - caman, crooked, and scaradh, to scatter.

1 Ruadh does not mean absolutely red, but reddish. Welsh : Rhydh. It means also power, virtue, strong, valiant. 


\section{CRUCIFERE.}

(From Latin crux, crucis, a cross, and fero, to bear, the petals being arranged crosswise.)

Crambe maritima-Seakale. Gaelic: praiseag tragha, the shore pot-herb,-from the Irish praiseach, Gaelic praiseag, a little pot (a common name for pot-herbs). Càl na màra, seakale (from Greek, xavios; Latin, caulis; German, kohl; Saxon, canvl; English, cole or kale; Irish, call; Welsh, cawl.)

Isatis tinctoria - Woad. The ancient Celts used to stain their bodies with a preparation from this plant. Its pale-blue hue was supposed to enhance their beauty, according to the fashion of the time. Gaelic: guirmean, the blue one. Irish and Gaelic: glas lus, pale-blue weed. Welsh : glas lys. Formerly called Glastum.

"Is glas mo luibh."-Ossiax.

Pale-blue is the subject of my praise.

On account of the brightness of its manufactured colours the Celts called it gzoed (griede in French to this day), whence the Saxon wad and the English woad.

Thlaspi arvense-Penny-cress. Gaelic: praiseach feidh, deer's pot-herb. Irish : preaseach fadh, a deer's pot-herb.

Capsella Bursa-pastoris-Shepherd's purse. Gaelic: his na fola, the blood-weed; an sporran, the purse. Irish : sraidin, a lane, a walk. Welsh: purs y bugail, shepherd's purse (bugail, from Greek ßvко入оs, a shepherd).

Cochlearia officinalis - Scurvy-grass. Gaelic: a maraich, sailor; carran, the thing for scurvy, possessing antiscorbutic properties. "Plaigh na carra," the plague of leprosy (Stuart). "Duine aig am bheil carr," a man who has the scurvy (Stuart in Lev.) Welsh: mor luyau, sea-spoons; llysie'r blueg, scurvygrass (from blueg, scurvy). Irish : biolair tràgha,-biolair, dainty, and trigha, shore or seaside.

Armoracia rusticana (armoracia, a name of Celtic origin,-from ar, land; mor or mar, the sea; ris, near to,-a plant growing near the sea). English: horse-radish. Gaelic: meacan-each, the horse-plant. Irish : racadal, perhaps from an old word rac, a king, a prince, and adhal, desire-i.e., the king's desire.

Raphanus raphanistrum-Radish. Gaelic: meacan ruadh, the reddish plant, from the colour of the root. Irish : fiadh roidis, wild radish. 
Cardamine pratensis-Cuckoo flower, ladies' smock. Gaelic : plur na cubhaig, the cuckoo-flower. Gleoran, from gleote, handsome, pretty. The name is given to other cresses as well. Biolair-ghriagain, the bright sunny dainty.

Cakile maritimum-Sea gilly-flower rocket. Gaelic: fearsaideag; meaning uncertain, but probably from Irish saide, a seat (Latin, sedes), the sitting individual-from its procumbent habit.

Nasturtium officinalis-Water-cress. Gaelic, biolair, a dainty, or that which causes the nose to smart, hence agreeing with nasturtium (Latin: nasus, the nose, and tortus, tormented). Durlus,-dur, water, and lus, plant. Dobhar-lus,-dobhar, water. Welsh : berzeyr dzeffr, water-cress. The Gaelic and Irish bards used these names indefinitely for all cresses.

"Sa bhiolair luidneach, shliòm-chluasach.

Glas, chruinn-cheannach, chaoin ghorm-nealach;;

Is i fàs glan, uchd-ard, gilmeineach,

Fuidh barr geal iomlan, sonraichte."-M'INTYRE.

Its drooping, smooth, green, round-leaved water-cress growing so radiantly, breast-high, trimly; under its remarkably perfect white flower.

"Dobhrach bhallach mhìn."-M'INTYRE.

Smooth-spotted water-cress.

Sisymbrium sophia-Flixweed. Gaelic: fineal Mhuire, the Virgin Mary's fennel. Welsh : piblys, pipe-weed.

Erysimum alliaria-Garlic mustard, sauce alone. Gaelic: garbhraitheach, rough, threatening.

Cheiranthus cheiri-Wallfower, gilly-flower. Gaelic: lus leth an samhraidh, half the summer plant. Irish: the same. Welsh : bloden gorphenaf, July flower or gilly-flower. Wedgwood says gilly-flower is from the French girofié.

Brassica rapa-Common turnip. Gaelic, neup; Irish, ncip; Welsh, maipen; Scotch, neep (and naveze, French, navet); corruptions from Latin napus.

B. campestris-Wild navew. Gaelic: neup fadhain, wild turnip.

B. oleracea-Seakale or cabbage. Gaelic and Irish : praiseach bhaidhe, the pot-herb of the wave (baidhe, in Irish, a wave. Morran,-mor (Welsh), the sea, its habitat the seaside. Cal colbhairt-the kale with stout fleshy stalks (from colbh, a stalk of a plant, and art, flesh), cal or cadhal. Welsh: carel, kale. Gaelic : cal-cearslach (cearslach, globular), cabbage ; cdl gruidhean (with grain like flowers), cauliflower; colag (a little cabbage), cauliflower; garadh càil, a kitchen-garden. 
" Dh' itheadh biolair an fhuarain

'S air bu shuarach an cal." -M 'DonalD.

I would eat the cress of the wells.

Compared to it, kale is contemptible.

Sinapis arvensis-Charlock, wild mustard. Gaelic: marag bhuidhe, the yellow sausage (to which the pod is supposed to bear some resemblance). Sceallan,_sceall, a shield. Sgealag (Shaw),-sgealpach, biting. Mustard, from the English.

"Mar ghrainne de shiol mustaird."-STUART.

Like a grain of mustard-seed.

Gaelic: praiseach garbh, the rough pot-herb.

\section{RESEDACE}

Reseda luteola_Weld, yellow weed. Gaelic: lus buidhe mòr, the large yellow weed. Irish: buidhe mòr, the large yellow. Welsh : llysie lliu, dye-wort. Reseda, from Latin resedo. Gaelic: reidh, to calm, to appease.

\section{Cistacee.}

(From Greek $\kappa \iota \sigma \tau \eta, k i s t e$, a box or capsule, from their peculiar capsules. Latin, cista ; Gaelic, ciste; Danish, kiste.)

Helianthemum vulgare-Rock-rose. Gaelic: grian ròs, sunrose; plìr na gréine, flower of the sun (also heliotrope). Welsh : blodaw'r haul, sun-flower.

\section{VIOLACEE.}

(From Greek lov, ion, a violet,- the food given to the cow Io, one of Jupiter's mistresses.)

Viola odorata-Sweet violet. Gaelic: fail chuach, scented bowl; fail, scent, and cuach, a bowl hollow as a nest. Scotch: quaich, cogie (dim.), a drinking-cup.

"Fail chuachaig ar uachdar a fheoir."-M'FARLANE.

Scented violet on the top of the grass.

V. canina-Dog-violet. Gaelic: dail chuach, field-bowl (dail, a field). Danish : dal, a valley.

\footnotetext{
"Gun sobhrach gun dail chuach, Gun lus uasal air càrnn."-M'INTYRE.

Without primrose or violet, Or a gay flower on the heap.
} 
Sail chuach,-sail, a heel (from its spur).

"Coille is guirme sàil chuach."-Old Song.

A wood where violets are bluest.

Irish : biodh a leithid, the world's paragon; also fanaisge, probably from fan, weak, faint, agreeing in meaning with the Welsh name, crinllyns, a fragile weed.

\section{Droserace.e.}

(From Greek $\delta \rho \sigma \epsilon \rho o s$, droseros, dewy, because the plants appear as if covered with dew.)

Drosera rotundifolia - Round-leaved sundew. Gaelic: ròs an ' 'solais, sun-rose or flower; geald-ruidhe or dealt ruaidhe, very red dew; lus na fearnaich, the plant with shields (its leaves have some resemblance to shields). Irish : eil druich (eil, to rob, and druich, dew), the one that robs the dew; druichdin mona, the dew of the hill. Welsh : doddedig rudd,-dod, twisted thread, and rudd, red, the plant being covered with red hairs.

\section{POLygalace}

(From Greek $\pi \circ \lambda v$, poly, much, and $\gamma \alpha \lambda \alpha$, gala, milk.)

Polygala vulgaris-Milkwort. Gaelic: lus a bhaine, milkwort. Irish: lusan baine, the same meaning, alluding to the reputed effects of the plants on cows that feed upon it.

\section{CaryophyllaceÆ.}

Saponaria officinalis-Soapwort, bruisewort. Gaelic: gairgeancregach. Irish: gairbhin creugach, the bitter one of the rocks; garbhion, bitterness, and creugach, rocky. The whole plant is bitter, and was formerly used to cure cutaneous diseases. Lus an shiabunn, the soapwort. Welsh: sebonllys, the same meaning (sebon, soap), Latin sapo, so called probably because the bruised leaves produce lather like soap. Soap was a Celtic invention.

"Prodest et sapo. Gallorum hoc inventum,

Rutilandis capillis, ex sevo et cinere."-PLINy.

Lychnis flos-cuculi-Ragged robin. Gaelic: plur na cubhaig, the cuckoo flower; curachd na cubhaig, the cuckoo's hood.

L. diurna-Red campion. Gaelic: cirean coileach, cockscomb ; in some places corcan coille, red woodland flower.

L. githago-Corn-cockle. Gaelic: brog na cubhaig, the cuckoo's 
shoe. Luibh laoibheach, -laoi, day, and beachd, to observe-ie,, the plant observed for a day. Irish : cogall, from coch (Welsh), red; hence cockle. French : coquille. Welsh : gith, cockle or its seed, a corruption from githago, or vice versâ.

Spergula arvensis-Spurrey. Gaelic: cluain lin,-cluain, fraud, and lin, flax-i.e., fraudulous flax. Carran, twisted or knotted. Scotch : yarr. Irish : cabrois,-cab, a head; rois, polished.

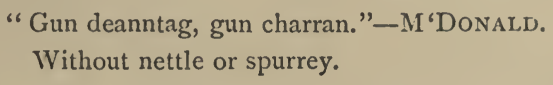

Arenaria alsine-Sandwort. Gaelic : flige, perhaps from fiche, water, growing in watery or sandy places.

Stellaria media-Chickweed. Gaelic: fiodh, an excrescence (Armstrong), sometimes written fluth. Irish: lia, wetting (Gaelic: fluich, wet); compare also floch, soft (Latin : flaccus). Welsh : gzelydd, the soft or tender plant.

S. Holostea-The greater stitchwort. Gaelic: tuirseach, sad, dejected. Irish : tursarrain, the same meaning; and Stellaria graminea, tursarranin, the lesser stitchwort. Welsh: $y$ zennwlydd, the fair soft-stemmed plant, from gzenn and gwlydd, soft tender stem.

Cherleria sedoides-Mossy cyphel, found plentifully on Ben Lawers. No Gaelic name, but seorsa coinich, a kind of moss.

Cerastium alpinum-Mouse-ear chickweed. Gaelic : cluas an luch, mouse-ear.

\section{LINACEE.}

Linum usitatissimum-Flax. Gaelic: lion, gen. singular lin.

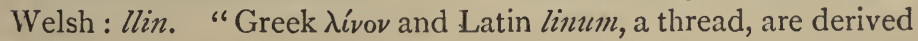
from the Celtic."-Loudon.

\section{"Iarraidh i olan agus lion." -STUART (Job). She will desire wool and flax.}

L. catharticum-Fairy flax. Gaelic: lion na bean sith, fairy woman's flax; miosach, monthly, from a medicinal virtue it was supposed to possess; mionach, bowels; lics caolach, slender weed: compare also caolan, intestine (Latin: colon, the large intestine). Both names probably allude to its cathartic effects. Stuart, in Lightfoot's 'Flora,' gives these names in a combined form,-an caol miosachan, the slender monthly one. Irish : ceolagh.

1 This plant is sometimes called Curach na Cubhaig, and Cochal-(hood or cowl). Latin : cucullus. 


\section{MalvaCeÆ.}

Latin: malva, mallows. Gaelic: maloimh, from Greek $\mu a \lambda a ́ \chi \eta$, malache, soft, in allusion to the soft mucilaginous properties of the plants.

"A' gearradh sios maloimh laimh ris na preasaibh, agus freımhan aiteil mar bhiadh."-STUART (Job xxx. 4).

"Who cut up mallons by the bushes, and juniper roots for their meat."

Welsh: meddalai, what softens. Gaelic: mil mheacan, honeyplant ; gropais or grobais (M'Donald) from Gothic, grob, English, grub, to dig. The roots were dug, and boiled to obtain mucilage.

Malva rotundifolia_Dwarf mallow. Gaelic and Irish : ucas frangach,-ucas from Irish uc, need, whence uchd, a breast (Greek, o้ $\chi \theta \eta$ - the mucilage being used as an emollient for breastsand frangach, French-i.e., the French mallow.

M. sylvestris-Common mallow. Gaelic: ucas fheadhair, wild mallow.

Althæa officinalis-Marsh-mallow. Gaelic and Irish : leamhad, perhaps from leamhach, insipid ; fochas, itch, a remedy for the itch (ochas, itch). Welsh : morhocys, - mor, the sea, and hocys, phlegmproducer, it being used for various pulmonary complaints.

\section{TILIACEÆ.}

Tilia europea-Lime-tree, linden. Gaelic: craobh theile. Irish : crann teile,-tcile, a corruption from tilia. Welsh : pis greydden.

\section{HYPERICACEÆ.}

Hypericum perforatum - The perforated St John's wort. Gaelic and Irish : eala bhuidhe (sometimes written eala bhi), probably from eal (for neul), aspect, appearance, and bhuidhe or bhi, yellow.

\section{"An eala bhuidhe s'an noinean bàn}

S'an t'sobhrach an gleann fàs, nan luibh

Anns am faigheadh an leighe liath

Furtach fiach, do chreuch a's leòn."-Collath.

In the glen where the St Fohn's wort, the white daisy, and the primrose grow, the grey doctor will find a valuable remedy for every disense and wound.

"The belief was common among the Caledonians that for all the diseases to which mankind is liable there grows an herb somewhere, and not far from the locality where the particular disease prevails, the proper application of which would cure it."M'KFNZIE. 
"Sobhrach a's eala bhi 's barra neoinean."-M'INTYRE.

Primrose, St Fohn's wort, and daisies.

Allas Mhuire (Mhuire, the Virgin Mary; allas, perhaps another form of the preceding names)-Mary's image, which would agree with the word hypericum. According to Linnaeus it is derived from Greek iviép, uper, over, and $\epsilon i \kappa \omega v$, eikon, an image-that is to say, the superior part of the flower represents an image.

Caod aslachan Cholum chille, from Colum and cill (church, cell), St Columba's flower, the saint of Iona, who reverenced it and carried it in his arms (caod,-(Irish) caodam, to come, and aslachan, arms), it being dedicated to his favourite evangelist St John." "Formerly it was carried about by the people of Scotland as a charm against witchcraft and enchantment " (Don). Welsh : y fendigaid, the blessed plant. French: la toute-saine. English: tutsan.

'The badge of Clan M'Kinnon.

\section{ACERACE}

("Acer, in Latin meaning sharp, from ac, a point, in Celtic."Du Theis.)

Acer campestris-Common maple. Gaelic and Irish : craobh mhalip or malpais; origin of name uncertain, but very likely from $m a l$, a satchel or a husk, from the form of its samara. Some think the name is only a corruption of maple-Anglo-Saxon, mapal. Welsh: masarnen. Gothic: masloenn (from mas, fat), from its abundance of saccharine juice.

A. pseudo-platanus-Sycamore. Gaelic and Irish : craoblh sice, a corruption from Greek sycaminos. The old botanists erroneously believed it to be identical with the sycamine or mulberry-fig of Palestine.

"Nam biodh agaidh creidimh, theiradh sibh ris a chrasbh shicamin so, bi air do spionadh as do fhreumhaibh."-STUART.

If ye had faith ye might say to this sycamore tree, Be thou plucked up by the root.-St Luke xvii. 6 .

Craobh pleantrinn, corruption of platanus or plane-tree. Irish : crann bàn, white tree. Fir chrann, same meaning.

The badge of Clan Oliphant.

\section{VINIFERE.}

Vitis (from the Celtic gzey'd, a tree, a shrub. Spanish : vid. French : vigne).

${ }^{1}$ Similar ideas occur in other Irish names respecting this plant : Beachnuadh Columcille, beachnuadh beinionn, beachnuadh firionn,-beach, to embrace; nuadh, new ; beinionn a little woman ; firion $n_{2}$ a little man. 
Vitis vinifera-Vine. Gaelic: crann fiona, fionan. Irish: fion, wine. Greek : Fouv-ov. Latin : vin-um. Fion dearc, a grape.

\section{Geraniaceq.}

(From Greek répavos, geranos, a crane. The long beak that terminates the carpel resembles the bill of a crane ; English : cranebill. Gaelic: crob priachain (Armstrong), the claw of any rapacious bird.) Lüs-gnà-ghorm. (M'Kenzie.) Evergreen plant.

Geranium Robertianum-Herb Robert. Gaelic and Irish: righeal cuil (from righe, reproof, and cuil, fly, gnat, insect), the fly reprover. Riaghal cuil, also rial chuil, that which rules insects; Earbull righ (earbull, a tail).

\section{"Insects are said to avoid it." - Don.}

Ruidel, the red-haired. Lus an Eallan, the cancer weed. Righeal righ. Irish : righean righ, that which reproves a king (righ, a king), on account of its strong disagreeable smell. Welsh : troedrydd, redfoot. Llysie Robert, herb Robert.

G. sanguineum-Bloody cranesbill. Gaelic : creachlach dearg, the red wound-healer (creach, a wound). Gcranium Robertianum and Geranium sanguineum have been and are held in great repute by the Highlanders, on account of their astringent and vulnerary properties.

\section{OXALIDACEÆ.}

(From Greek $\dot{\jmath}^{\xi} \dot{v}$ s, oxys, acid, from the acid taste of the leaves.)

Oxalis acetosella_Wood-sorrel. Gaelic : samh, shelter. It grows in sheltered spots. Also the name given to its capsules. Also summer. It may simply be the summer flower.

\footnotetext{
"Aig itheach saimh," eating sorrel.
}

Seamrag. Irish: seamrog (shamrock) (seam, mild and gentle), little gentle one. Referring to its appearance.

"Le-seamragan's le neonainean,

'S'gach lus a dh'fheudain ainmeachadh

Cuir anbharra dhreach boidhchead air." -M'INTYRE.

With wood-sorrel and with daisies,

And plants that I could name,

Giving the place a most beautiful appearance.

Surag, the sour one; Scotch: sourock (from the Armoric sur, Teutonic suer, sour). Welsh: suran y gog, cuckoo's sorrel. 
Gaelic : biadh nan eoinean, birds' food. Irish : billeog nan eun, the leaf of the birds.

\footnotetext{
"Timcheall thulmanan diàmhair

Ma 'm bi'm biadh-ionain fàs." - M'Donal.D.

Around sheltered hillocks

Where the wood-sorrel grows.
}

Feada coille, candle of the woods, name given to the flower; feadh, a candle or rush.

\footnotetext{
"Mar sin is leasachan soilleir,

Do dh' fheada-coille na'n còs."-M'Donald.

Like the flaming light

Of the wood-sorrel of the caverns.
}

\section{Celastracee.}

Euonymus europæus - Common spindle-tree. Gaelic and Irish : oir, feoras, - oir, the east point, east. "A tir an oir," from the land of the East (Oirip, Europe), being rare in Scotland and Ireland, but common on the Continent. Oir and feoir also mean a border, edge, limit, it being commonly planted in hedges. Whether the narne has any reference to these significations it is very difficult to determine with certainty. Oir, the name of the thirteenth letter, $\mathrm{O}$, of the Gaelic and Irish alphabet. It is worthy of notice that all the letters were called after trees or plants :-

\begin{tabular}{|c|c|c|c|c|c|c|c|}
\hline A & . & $\begin{array}{l}\text { Gaelic. } \\
\text { Ailm. }\end{array}$ & $\begin{array}{l}\text { English. } \\
\text { Elm. }\end{array}$ & I & & $\begin{array}{l}\text { Gaelic. } \\
\text { Luis. }\end{array}$ & $\begin{array}{l}\text { English. } \\
\text { Quicken. }\end{array}$ \\
\hline B & 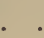 & Beite. & Birch. & MI & & Muir. & Vine. \\
\hline c & . & - Coll. & Hazel. & $\mathrm{N}$ & & Nuin. & Ash. \\
\hline D & . & . Dur. & Oak. & 0 & & Oir. & Spindle-tree. \\
\hline$E$ & . & Eagh. & Aspen. & $\mathbf{P}$ & • & Peith. & Pine. \\
\hline $\mathbf{F}$ & . & - Fearn. & Alder. & $\mathrm{R}$ & & Ruis. & Elder. \\
\hline G & 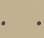 & Gath. & Ivy. & $\mathbf{s}$ & • & Suil. & Willow. \\
\hline H & & Huath. & White-thorn. & $\mathbf{T}$ & & Tin. & Heath. \\
\hline $\mathrm{T}$ & & Iogh. & Yew. & U & & Uir. & Whitethorn. \\
\hline
\end{tabular}

\section{RHAMNACEÆ.}

Rhamnus (from Gaelic ramh, Celtic ram, a branch, wood).

"Talamh nan ramh."-Ossian.

The country of woods.

The Greeks changed the word to $\rho$ á $\mu \nu$ os and the Latins to ramus.

R. catharticus-Prickly buckthorn. Gaelic : ramh droighionn, prickly wood. Welsh : rhafnzwydden,-rhaf, to spread; woydd, tree. 
Juglans regia-The Walnut. Gaelic: craobh-ghallchno-gall, a foreigner, a stranger; cno, a nut.

\section{LEGUMINIFERÆ.}

Gaelic: luis feidhleagach, pod-bearing plants. Bar guc, papilionaceous flowers (Armstrong). Por-cochullach, leguminous.

"Bar guc air mheuraibh nosara."-M'INTYRE.

Blossoms on sappy branches.

Sarothamnus scoparius-Broom. Gaelic: bealaidh or bealwidh (probably from bcal, Baal, and widh, favour), the plant that Belus favoured, it being yellow-flowered (see Caltha palustris). Yellow was the favourite colour of the Druids (who were worshippers of Belus), and also of the bards. Ossian describes the sun "grian bhuidhe," the yellow sun; M'Intyre, his Isabel, as

"Iseabel og

An òr fhuilt bhuidh."

Young Isabel with the golden-yellow hair.

Irish : brum; and Welsh : ysgrub. Gaelic: sguab, a brush made from the broom. Latin: scoparius. Giolcach sleibhe (giolc, a reed, a cane, a leafless twig; sleibhe, of the hill).

The badge of the Clan Forbes.

Cytisus laburnum - Laburnum. Gaelic: bealuidh frangach (in Breadalbane), in some parts sasunach, French or English broom (Ferguson). Frangach is very often affixed to names of plants of foreign origin. This tree was introduced from Switzerland in 1596 . Craobh obrun, a corruption of laburnum.

Ulex-Name from the Celtic $e c$ or $a c$, a prickle (Jones).

U. europæus-Furze, whin, gorse. Gaelic and Irish : conasg, from Irish conas, war, because of its armed or prickly appearance. Welsh : eithin, prickles.

\section{"Lan conasg is phreasaibh."-OLD SONG.}

Full of furze and bushes.

Not common in the Highlands, but plentiful about Fortingall, Perthshire.

Ononis arvensis-Rest-harrow. Gaelic and Irish : srcang bogha, bowstring. Welsh : tagadr, stop the plough ; eithin yr eir, ground prickles. Scotch : cammock, from Gaelic cam, crooked.

Trigonella ornithopodioides-Fenugreek, Greek hay. Gaelic : ionntag-greugach (Armstrong), Greek nettle; crubh-eoin, Birds' shoe. Welsh : y grog-zeryan.

Trifolium repens-White or Dutch clover. Gaelic and Irish: 
seamar bhan, the fair gentle one (see Oxalis); written also sameir, siomrag, seamrag, seamrog. Wood-sorrel and clover are often confounded, but seamar bhan is invariable for white clover, and for Trifolium procumbens, hop trefoil, samhrag bhuidhe, yellow clover.

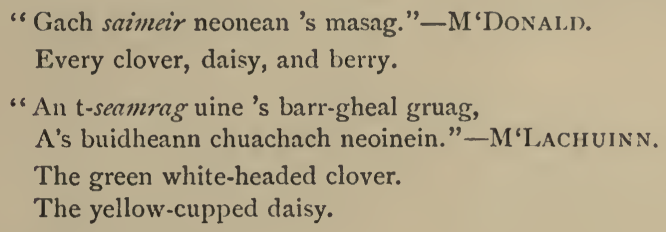

The badge of Clan Sinclair.

T. pratense-Red clover. Gaelic : seamar chapuill, the mare's

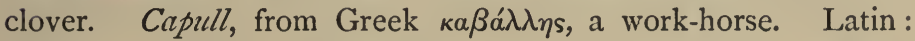
caballus, a horse. Tri-bilean, trefoil, three-leaved. Welsh: tairdalen, the same meaning. Meillonem, honeywort, from mêl, honey. Gaelic: siigrg, Scotch sookie, the bloom of clover, so called because it contains honey, and children suck it.

T. minus - Small yellow clover. Gaelic: seangan, small, slender.

T. arvense-Hare's-foot clover. Gaelic : cas maidhiche (Armstrong), hare's foot.

Lotus corniculata-Bird's-foot trefoil. Gaelic : barra mhislean,-barra, top or flower; mislean, anything that springs or grows.

"Glacag misleanach."-MACFARLANE.

A grassy dell.

Anthyllis vulneraria - Kidney vetch, or Lady's Fingers. Gaelic: meoir Mhuire, Mary's fingers ; cas an uain, lamb's foot.

Vicia ${ }^{1}$ sativa-Vetch. Gaelic and Irish : fatghal, nutritious (from Irish faadh, now written biadh, food); peasair fadhain, wild pease; peasair chapuill, mares' pease. Welsh: idbys, edible pease. Irish : pis feadhain, wild pease ; pis dubh, black peas.

v. cracca - Tufted vetch. Gaelic: pesair nan luch, mice pease ; pesair (Latin, pisum; Welsh, pys ; French, pois, pease), are all from the Celtic root pis, a pea.

v. sepium-Bush vetch. Gaelic : peasair nam preas, the bush peas.

Lathyrus pratensis - Yellow vetchling. Gaelic: peasair bhuidhe, yellow peas. Irish : pis bhiidhe, yellow peas.

1 Vicia (from grvig, Celtic, whence Greek Bıkıv, Latin vicia, French vesce, English velch).-LOUDON. 
Ervum hirsutum-Hairy vetch or tare (from erv, Celtic-arv, Latin, tilled land). Gaelic: peasair an arbhar, corn peas. Welsh : pysen y ceirch,_ceirch, oats. Gaelic: gall pheasair, a name for lentils or vetch. Gall, sometimes prefixed to names of plants having lowland habitats, or strangers.

"Lan do ghall pheasair."-STUART, 2 Sam.

Full of lentils.

Faba vulgaris-Bean. Gaelic : ponair. Irish : poneir. Cornish : ponar (from the Hebrew hi:, pul, a bean (Levi). Gaelic: ponair frangach, French beans; ponair airneach, kidney beans; ponair chapuill, buckbean (Menyanthes trifoliata).

"Gabh thugad fòs cruithneachd agus eorna, agus pònair, agus peasair, agus meanbh-pheasair, agus peasair fhiadhain, agus cuir iad ann an aon soitheach, agus dean duit fèin aran duibh."-STUART, Ezekiel iv. 9.

"Take thou also unto thee wheat, and barley, and beans, and lentiles, and millet, and fitches, and put them in one vessel, and make thee bread thereof."

Orobus tuberosus-Tuberous bitter vetch (from Greek, op $\rho \omega$, oro, to excite, to strengthen, and $\beta$ ov̂s, an ox). Gaelic and Irish : cairmeal (Armstrong),-cair, dig; meal, enjoy; also mall; Welsh : moel, a knob, a tuber-i.e., the tuberous root that is dug; corrameille (M'Leod and Dewar).

"Is clann bheag a trusa leolaicheann ${ }^{1}$

Buain corr an co's nam bruachagan." -M'INTYRE.

Little children gathering . . .

And digging the bitter vetch from the holes in the bank.

Corra, a crane, and meillg, a pod, the crane's pod or peas. Welsh: py's y garanod, crane's peas; garan, a crane. "The Highlanders have a great esteem for the tubercles of the roots; they dry and chew them to give a better relish to their whisky. They also affirm that they are good against most diseases of the thorax, and that by the use of them they are enabled to repel hunger and thirst for a long time. In Breadalbane and Ross-shire they sometimes bruise and steep them in water, and make an agreeable fermented liquor with them, called cairm. They have a sweet taste, something like the roots of liquorice, and when boiled are well flavoured and nutritive, and in times of scarcity have served as a substitute for bread" (Lightfoot).

1 Leolaicheann, probably Trollius europaus (the globe flower), from Òl, olachan, drink, drinking. Children frequently use the globe flower as a drinking-cup. Scotch : Iuggie gowan. Luggie, a small wooden dish; or it may be a corruption from trol or trollen, an old German word signifying round, in allusion to the form of the flower, hence Trollius. 


\section{ROSACE $\approx$.}

(From the Celtic. Gaelic, ros; Welsh, rhos; Armoric, rosen; Greek, podov: Latin, rosa.)

Prunus spinosa-Blackthorn, sloe. Gaelic: preas nan airneag, the sloe bush. Irish : airne, a sloe.

"Sùilean air lidh airneag." - Ross.

Eyes the colour of slues.

Sgitheach dibh,-the word sgith ordinarily means weary, but it means also (in Irish) fear; $d u b h$, black, the fearful black one, but probably in this case it is a form of sgeach, ${ }^{1}$ a haw (the fruit of the white thorn), the black haw. Welsh: eirinen $d d u$, the black plum ; eiryn, a plum.

"Crùn sgitheach an aite crùn righ. $-M$ 'Ellar.

A crown of thorns instead of a royal crown.

Droighionn dibh, the black penetrator (from druid, to penetrate, pierce, bore). Compare Gothic, thruita; Sanscrit, trut; Latin, trit; Welsh, draen; German, dorn; English, thom.

"Croin droignich 'on ear's o'niar."-OLD POEM.

Thorn-trees on either side.

P. damascena-Damson. Gaelic and Irish : daimsin (corruption).

P. insititia - Bullace. Gaelic and Irish : bulastair. Compare Breton, bolos; Welsh, biolas, sloes.

P. domestica_Wild plum. Gaelic : plumbais fiadhaimn, wild plum; plumbais seargta, prunes. Latin : prumum.

P. armeniaca-A pricot. Gaelic: apricoc. Welsh : bricyllen. Regnier supposes from the Arabic berkoch, whence the Italian albicocco, and the English apricot; or, as Professor Martyn observes, a tree when first introduced might have been called a "præcox," or early fruit, and gardeners taking the article " $a$ " for the first syllable of the word, might easily have corrupted it to apricots.

P. cerasus-Cherry-tree. Gaelic: craobh shiris, a corruption of Cerasus, a town in Pontus in Asia, from whence the tree was first brought.

" Do bheul mar t' siris."

Thy mouth like the cherry.

Welsh : ceiriosen.

1 Sgeach, also a bush. 
P. padus-Bird cherry. Gaelic: craobh fliodhag, from fiodh, wood, timber; fodhach, a shrubbery.

P. avium-Wild cherry. Gaelic: geanais, the gean. French : guigne, from a German root.

Amydalus communis-Almond. Gaelic: amon, cno ghrengach, Greek nut.

A. persica-Peach. Gaelic: peitseag, from the English.

Spiræa ulmaria - Meadow-sweet, queen of the meadow. Gaelic: crios (or cneas) Chu-chulainn.1 The plant called "My lady's belt" (M'Kenzie). "A flower mentioned by M'Donald in his poem 'Alt an t-siucair,' with the English of which I am not acquainted" (Armstrong).

It is not mentioned in the poem referred to, but in "Oran an't Samliraidh" - The Summer Song.

"S"curraidh faileadh do mhuineil A chrios-Chì-Chulainn nan càrn!

$\mathrm{Na}$ d' chruinn bhabaidean riabhach,

Lòineach, fhad luirgneach, sgiamhach.

$\mathrm{Na}$ d' thuim ghiobagach, dreach mhin,

Bharr-bhùidhe, chasurlaich, àird ;

Timcheall thulmanan diamhair

Ma'm bi 'm biadh-ionain a fàs."-M'DoNaL.D.

Sweetly scented thy wreath, Meadow-szeet of the cairns! In round brindled clusters, And softly fringed tresses, Beautiful, tall, and graceful, Creamy flowered, ringleted, high ;

Around sheltered hillocks

Where the wood-sorrel grows.

Welsh : llysiu'r forzoyn, the maiden's flower.

S. filipendula-Dropwort. Gaelic and Irish : greaban-probably from greadh, to prepare food.

"A gread na cuilm."-Ossian.

Preparing the feast.

Linnæus informs us that, "in a scarcity of corn the tubers have been eaten by men instead of food." Or from greach, a nut. Welsh : crogedyf,-crogi, to suspend. The tuberous roots are suspended on filaments; hence the names filipendula and dropzert.

1 Cù chullin's belt. Cùchullin was the most famous champion of the Ulster militia in the old Milesian times. He lived at the dawn of the Christian era. He was so called from $C u$, a hound, and Ullin, the name of the province. Many stories are still extant regarding him. 
Geum rivale-Water avens. ${ }^{1}$ Gaelic : machall wisge; in Irish : macha, a head, and all, all-i.e., allhead-the flower being large in proportion to the plant. Uisge, water. It grows in moist places only.

G. urbanum-Common avens. Gaelic: machall coille,-coille, wood, where it generally grows.

Dryas octopetala - White dryas. Gaelic: machall monaidh, the large-flowered mountain plant. (The name was given by an old man in Killin from a specimen from Ben Lawers in 1870.)

Potentilla anserina-Silverweed, white tansy. Gaelic: brisgean (written also briosylan, brislean), from briosg or brisg, brittle. Brisgean milis, sweet bread. "The brisgean, or wild skirret, is a succulent root not unfrequently used by the poorer people in some parts of the Highlands for bread" (Armstrong).

The skirret (see Sium sisarum) is not native. The plant here alluded to is Potentilla anserina. Bar bhrisgean, the flower. Welsh : torllieydd, from tori, to break.

P. reptans - Cinquefoil. Gaelic: meangach, branched or twigged, - meang, a branch; because of its runners, its long leaf, and flower-stalks. Cuig bhileach, five-leaved. Irish : cuig mhear Mhuire, Mary's five fingers. Welsh: blysiu'r pump, same meaning.

P. tormentilla - Common potentil, or tormentil. Gaelic : leanartach (from leanar, passive of verb lean, to follow). So common on the hills that it seems to follow one everywhere. Bàr braonan-nan-con, the dogs' briar bud. Braonan fraoch (fraoch, heather). Braonan, the bud of a briar (Armstrong). Braonan bachlag, the earth-nut (Bunium flexuosum) (M'Donald), from braon, a drop.

"Min-fheur chaorach is bàra-bhraonan."-M'INTYRE.

Soft sheep grass and the flower of the tormentil.

Irish : neamhnaid, a pearl (in Gaelic : neonaid). Welsh : tresgl y moch.

Comarum palustre-Marsh cinquefoil. Gaelic : cuig bhileach uisge, the water five-leaved plant.

Fragaria vesca - Wood strawberry. Gaelic: subh (or sitth)

1 Avens, a river, from the Celtic an. Welsh : avon. Gaelic : abhainn. Many river names in Europe and Asia are derived from this root-e.g., Rhenus, the Rhine-reidh-an, the placid water. Garumnus, Garonnegarbh-an, the rough water. Marne-marbh-an, the dead water. Seine, a contraction of seimh-an, the smooth water, \&c. 
thalmhain, the earth's sap, the earth's delight (from sibh or siggh, sap, juice; also delight, pleasure, joy, mirth) ; thalmhain, of the earth.

"Theirig subh-thalmhain nam bruach."-M'DONALD.

The wild strawberries of the bank are done.

Subhan laire, the ground sap; tlachd subh, pleasant fruit.

"Subhain laire s'faile ghroiseidean."-M'INTYRE.

Wild strawberries and the odour of gooseberries.

Suthag, a strawberry or raspberry.

"Gur deirge n'ant suthag an ruthodh tha'd ghruidb."

Thy cheeks are ruddier than the strawberry.

Irish : catog, the strawberry bush. Cath, seeds (the seedy fruit). Welsh : mefussen.

Rubus (from $r u b$, red in Celtic), in reference to the colour of the fruit in some species.

Rubus chamæmorus-Cloudberry. Gaelic: oireag, variously written,-oighreag, foighreag, fcireag. Irish : cireag (from circachd, beauty).

"Breac le feireagan is cruin dearg ceann."-M'INTYRE.

Checkered with cloudberries with round red heads.

"The cloudberry is the most grateful fruit gathered by the Scotch Highlanders" (Neill).

The badge of Clan M'Farlane.

Cruban-na saona, "the dwarf mountain bramble." (O'Reilly, Armstrong, and others). Probably this is another name for the cloudberry, but its peculiar and untranslatable name furnishes no certain clue to what plant it was formerly applied.

R. saxatilis-Stone bramble. Gaelic: caora bad miann, the berry of the desirable cluster. Ruiteaga, redness, a slight tinge of red.

R. idæus-Raspberry. Gaelic: preas sibh chraobh (craobh, a tree, a sprout, a bud), the bush with sappy sprouts.

"Fàile nan siuth-chraobh

A's nan ròsann." - M'INTYRE.

The odour of rasps and roses.

Welsh: mafon,-maf, what is clustering. Gaelic: preas shiidheag, the sappy bush. Siighag, the fruit (from sigh, juice, sap).

$\boldsymbol{R}$. fruticosus - Common bramble. Irish and Gaelic: dreas, plural dris. Welsh: dyrys, - the root rys, entangle, with prefix 
$d y$, force, irritation. In Gaelic and Welsh the words dris and drysien are applied to the bramble and briar indiscriminately.

"An dreas a fàs gu h-urar."-Ossian.

The bramble (or briar) freshly growing.

"Am fear theid san droighionn domh Theid me san dris dà."-Proverb.

If one pass through thorns to me,

I'll pass through brambles (or briars) to him.

Grian mluwine, the thorn (bush) that basks in the sun. Dris muine,-muine, a thorn, prickle, sting. Smear phreas (Irish : smeur), the bush that smears; smearag, that which smears (the fruit). Welsh: miar, the bramble. (Miar or meur in Gaelic means a finger.) Smearachd, fingering, greasing, smearing. (Compare Dutch, smeeren; German, schmieren, to smear or daub.) Dris-smear, another combination of the preceding names.

This plant is the badge of the Clan M'Lean.

R. cæsius-Blue bramble; dewberry bush. Gaelic: preasnan-gorm dhearc, the blueberry bush.

"Bar gach tolmain fo bhrat gorm dhearc."-M'DonalD.

Every knoll under a mantle of blueberries (dewberries).

The blue bramble is the badge of the Clan $\mathrm{M}$ ' Nab.

Rosa canina-Dog-rose. Gaelic: coin ròs, dogs' rose (coin, gen. plural of cì, a dog). Greek : $\chi v-\omega v$. Latin : canis. Sanscrit : cunas. Irish : cil. Welsh: ki.

Gaelic: coin droignionn, dogs' thorn. Earrdhreas or fearradhris, earrad, armour; suggested by its being armed with prickles.

"Mar mhucaig na fearra-dhris."-M'ElLAR.

Like hips on the briar.

Preas-nam-mucaig, the hip-bush - from muc (Welsh: moch), a pig, from the fancied resemblance of the seeds to pigs, being bristly. Irish : sgeach mhadra, the dogs' haw or bush. Welsh : merddrain. Gaelic: ros, rose ; cultivated rose, ros gharaidh.

"Bé sid an sealladh eibhinn!

Do bhruachan glè-dhearg ròs."

That was a joyful sight!

Thy banks so rosy red.

R. rubiginosa-Sweet-briar (briar, Gaelic : a bodkin or pin). Gaelic: dris chubhraidh, the fragrant bramble. Irish : syeachchumhra, the fragrant haw or bush. Cuirdris, the twisting briar, - cuir, gen. sing. of car, to twist or wind. 
Agrimonia eupatoria-Agrimony. Gaelic: mur-dhraidhean, - mur, sorrow, grief, affliction; draidhean, another form of dhroighionn (see Prunus spinosa). Draidh, or druidh, also means a magician, which may refer to its supposed magical effects on troubles as well as diseases. A noted plant in olden times for the cure of various complaints. Irish: marbh dhroighionn,marbh-dhruidh, a necromancer, or magician. Geur bhileach,geur, sharp, sour, rigid; bhileach, leaved;-on account of its leaves being sharply serrated, or because of its bitter taste. Mirean nam magh, the merry one of the field. Welsh : $y$ dorllwyd, the way to good luck.

Sanguisorba-Burnet. A bhileach losgain. The leaves good for burns and inflammations (losgadh, burning).

Alchemilla vulgaris-Common Lady's Mantle. Gaelic : copan an druichd, the dew-cup ; falluing mhuire, Mary's mantle. Irish: dhearna mhuire, Mary's palm. Gaelic: crub leomhainn, lion's paw; cota preasach nighean an righ, the princesses' plaited garment. Irish : leathach bhuidhe (leathach, livided).

Alchemilla alpina-Alpine Lady's Mantle. Gaelic: trusgan, mantle. The satiny under-side of the leaves of this and the other species has given rise to the names trusyan, falluing, cota, and the English name, I ady's Mantle.

"Tha trusgan faoilidh air cruit an aonich."-M'INTYRE.

The mantle-grass on the ridge of the mountain.

The hills about Coire-cheathaich and Ben Doran (the district described by the poet) are covered with this beautiful plant. 'The word trusgan, mantle, may be used in this instance in its poetic sense.

Mespilus germanica-Medlar. Gaelic : cran meidil (M'Donald), said to be a corruption of Mespilus. Greek : $\mu \epsilon \sigma o s$, half, and $\pi \iota \lambda \circ$ s, a bullet. The fruit resembles half a bullet.

Cratægus oxyacantha-Whitethorn, hawthorn. Gaelic: sgithcach geal, drioghionn geal (see Prumus spinosa), geal, white; preas nan syeachag; sgeach, a haw. Welsh : draenen wen, white thorn.

"Miòs bog nan ubhlan breac-mheallachd!

Gu peurach plumbach sgeachagach,

A' luisreadh sios le dearcagaibh,

Cir, mhealach, beachach, groiseideach."-M'LACHUinN.

Soft month of the spotted bossy apples !

Producing pears, plums, and haws,

Abounding in berries, wax,

Honey, wasps, and gooseberries. 
Uath or huath - the ancient Gaelic and Irish name-has several significations; but the root seems to be $h u$ (Celtic), that which pervades. Welsh: huad, that which smells or has a scent (huadgu, a hound that scents). "The name hawthorn is supposed to be a corruption of the Dutch hoeg, a hedge-thorn. Although the fruit is generally called a haw, that name is derived from the tree which produces it, and does not, as is frequently supposed, take its name from the fruit it bears."-Jones. Hawthorn may only be a corruption of Iuad-draen, scented thorns. The badge of the Clan Ogilvie.

Pyrus (from peren, Celtic for pear). Latin: pyrum. Armoric : pêr. Welsh: peren. French : poire.

Pyrus communis-Wild pear. Gaelic: craobh phenurain fadhain (peur, the fruit), the wild pear-tree.

Pyrus malus-" $\mathrm{Mel}$ or mal, Celtic for the apple, which the Greeks have rendered $\mu \eta \lambda o v$, and the Latins malus."-Don. Welsh : afal. Anglo-Saxon: apl. Norse : apal, apple. Gaelic: ubhal; craobh wbhal fadhain, the wild apple-tree.

"Do mheasan milis cubhraidh

Nan ubhlan's 'nam peur."-M'Donal.D.

Thy sweet and fragrant fruits, Apples and pears.

The old form of the word was adhul or abhul. The culture of apples must have been largely carried on in the Highlands in olden times, as appears from lines by Merlin, who flourished in A.D. 470 , of which the following is a translation:-

"Sweet apple-tree loaded with the sweetest fruit, growing in the lonely wilds of the woods of Celyddon (Dunkeld), all seek thee for the sake of thy produce, but in vain ; until Cadwaldr comes to the conference of the ford of Rheon, and Conan advances to oppose the Saxons in their career."

This poem is given under the name of Afallanau, or Orchard, by which Merlin perhaps means Athol-ie., Abhal or Adhulwhich is believed by etymologists to acquire its name from its fruitfulness in apple-trees. Goirteag (from goirt, bitter), the sour or bitter one (the crab-apple). Cuairtagan (the fruit); cuairt, round, the roundies. Irish : cueirt.

" 'San m'an Ruadh-aisriglı ah'fhas na cuairtagan."-M'INTYRE.

It was near the red path where the crab-apples grew.

This plant is the badge of the Clan Lamont. 
Pyrus aucuparia-Mountain-ash, rowan-tree. Old Irish and Gaelic: luis, drink (luisreog, a charm). The Highlanders formerly used to distil the fruit into a very good spirit. They also believed "that any part of this tree carried about with them would prove a sovereign charm against all the dire effects of enchantment or witchcraft." - Lightfoot ( 1772 ). Fuinseag coille, the wood enchantress, or the wood-ash (see Circea); craobh chaoran, the berry-tree (caor, a berry). Irish: pairtainn dearg, the red crab.

"Bu dh'eirge a ghruidh na caoran."-Ossian.

His cheeks were ruddier than the rowan.

" Sùil chorrach mar an dearcag,

Fo rosg a dh-iathas dlù,

Gruidhean mar na caoran

Fo n' aodann tha leam cùin."-AN CAILIN DILEAS DONN.

Thine eyes are like the blaeberry,

Full and fresh upon the brae,

Thy cheeks shall blush like the rowans

On a mellow autumn day.

(Translated by Professor J. S. Blackie.)

This plant is the badge of the Clan M'Lachlan.

Pyrus cydonia-Quince-tree. Gaelic: craobh chuinnse, corruption of quince, from French coignassa, pear-quince. Originally from Cydon in Candia.

\section{AURAnTIACE居.}

Citrus aurantium-The orange. Gaelic: or wbhal, golden apple; or mheas, golden fruit; oraisd, ${ }^{1}$ from Latin aurum. Irish : or. Welsh : oyr, gold.

" 'S Phœbus dàth na'n tonn

Air fiamh drensin."-M'DonalD.

And Phobus colouring the waves

With an orange tint.

Citrus medica-Citron. Gaelic: craobh shitroin.

Citrus limonum-Lemon. Gaelic: crann limoin. French: limon. Italian: limone.

1 Spelt by M'Donald properly orainis. His spelling generally is far from correct, and the same word often spelt different ways. He is also much given to translating a name from the English.-Fergusson. 


\section{MyRTACEe.}

Punica granatum-Pomegranate. Gaelic: gràn ubhal (gràn, Latin, granum), grain-apple.

"Tha do gheuga mar lios grìn ublan, leis a'mlıeas a's taitniche."-SoNG of Solomon.

Thy plants are an orchard of pomegranates with pleasant fruits. (Now generally written pomgranat in recent editions.)

Myrtus communis-Myrtle. Gaelic: miortal.

"An ait droighne fàsaidh an guithas, agus an ait drise fàsaidh am miortal." -Isaiail lv. 13 .

Instead of the thorn shall grow the fir, and instead of the briar, the myrtle.

\section{ONAGRACEE.}

Epilobium montanum-Mountain willow-herb. Gaelic: an seileachan, diminutive of seileach (Latin : salix, a willow), from the resemblance of its leaves to the willow. Welsh: helyglys, same meaning.

E. angustifolium - Rosebay. Gaelic: seileachan frangach, French willow. Feamainn (in Breadalbane), a common name for plants growing near water, especially if they have long stalks.

Circæa lutetiana and alpina - Enchantress's nightshade. Gaelic and Irish : fuinnseach. Not improbably from Irish uinnseach, playing the wanton-the reference being to the fruit, which lays hold of the clothes of passengers, from being covered with hooked prickles (as Circe is fabled to have done with her enchantments); or fuinn, a veil, a covering. The genus grows in shady places, where shrubs fit for incantations may be found. "Fuinn (a word of various significations), also means the earth; and seach, dry - i.e., the earth-dryer. Fuinnseagal (another Irish name), from seagal (Latin, secale), rye-i.e., ground-rye" (Brockie). Lus na h'oidhnan, the maiden's or enchantress's weed.

\section{LYTHRACEE.}

Lythrum salicaria - Spiked lythrum, purple loosestrife. Gaelic': lus an sith chainnt, the peace-speaking plant.

"Chuir Dia oirnn craobh sith chainnt, Bha da'r dionadh gu leoir."-IAN Lom.

God put the peace-speaking plant over us, Which sheltered us completely.

The name also applies to the common loosestrife, suggested probably by the Greek $\lambda v \sigma \iota s \mu a \chi \eta$, of which the English name 
"loosestrife" is a translation. Irish : breallan leana. Breal, a knob, a gland. It was employed as a remedy for glandular diseases, or from the appearance of the plant when in seed. Breallan means also a vessel. The capsule is enclosed in the tube of the calyx, as if it were in a vessel. Lean, a swamp. Generally growing in watery places.

\section{HALORAGEÆ.}

Myriophyllum spicatum and alterniflorum.-Water-milfoil. Gaelic and Irish: snaithe bhatheadh (from snaith, a thread, a filament; and bàth, drown), the drowned thread.

\section{Grossulariace.e.}

Ribes, said to be the name of an acid plant. (Rhèum ribes, mentioned by the Arabian physicians, a different plant). More probably from the Celtic riob, rib, or reub, to ensnare or entangle, to tear-many of the species being prickly. Latin : ribes. Gaelic: spiontag, currant, gooseberry. Irish: spiontog, spin. Latin : spina, a thorn; also spion, pull, pluck, tear away. Welsh : yspinem.

Ribes nigrum-Black currant. Gaelic: raosar dubh, the black currant. Raosar (Scotch, rizzar-from French, raisin; Welsh, rhyfion; Old English, raisin tree), for red currant.

R. rubrum-Red or white currants. Gaelic : raosar dearg or geal, red or white currants; dearc frangach, French berry.

R. grossularia - Gooseberry-bush. Gaelic: preas ghrosaid (written also groseag, grosaid), the gooseberry-from grossulus, diminutive of grossus, an unripe fig, - "so called because its berries resemble little half-ripe figs, grossi" (Loudon). French : groseille. Welsh : grwysen. Scotch : grozet, grozel.

"Suthan-lair's faile ghroseidean." -M'INTYRE.

Wild strawberry and the odour of gooseberries.

Crassulaceer.

(From Latin, crassus, thick-in reference to the fleshy leaves and stem. Gaelic: crasag, corpulent.)

Sedum rhodiola-Rose-root. Gaelic and Irish : hus nan laoch, the heroes' plant; laoch, from the Irish, meaning a hero, a champion, a term of approbation for a young man.

The badge of the Clan Gunn.

S. acre-Stonecrop, wall-pepper. Gaelic and Irish : grafan nan clach, the stone's pickaxe. Welsh : flyddarlys, prick madam. 
Also in Gaelic: glus-lann and glas lean, a green spot. IVelsh: manion y cerg.

S. telephium-Orpine. Scotch : orpie. Gaelic : orp (from the French, orpin). Lus nan laogh, the calf or fawn's plant; laogh, a calf, a fawn, or young deer, a term of endearment for a young child. Irish : laogh. Welsh: lho. Manx: leigh. Armoric: lue. Welsh: telefin (from Latin, telephium).

Sempervirum tectorum-House-leek. Gaelic: hus nan cluas, ${ }^{1}$ the ear-plant (the juice of the plant applied by itself, or mixed with cream, is used as a remedy for the ear-ache); lus glaraidh, the garden-wort; oirp, sometimes written norp (French, orpin); tin gealach, tineas na gealaich, lunacy - tinn, sick, and gealach, the moon (geal, white, from Greek, $\gamma a \lambda a$, milk);-it being employed as a remedy for various diseases, particularly those of women and children, and head complaints. Irish : sinicin, the little round hill; tir-pin, the ground-pine. Welsh : llysie pen-ty, house-top plant.

Cotyledon umbilicus-Navel-wort, wall-pennywort. Gaelic: lamha cat leacain, the hill-cat's glove. Irish : corn caisiol, the wall drinking-horn (from corn, a cup, a convex surface; from its peltate round convex leaves). Latin: cornu, a horn. Welsh : corn. French : corne; and caisiol, a wall (or any stone building), where it frequently grows.

\section{SAXIFRAGACEÆ.}

Saxifraga - Saxifrage. Gaelic : cloch-bhriseach (Armstrong), stone-breaker-on account of its supposed medical virtue for that disease. Welsh : cromil yr englyn.

S. granulata-Meadow saxifrage. Gaelic and Irish : moran, which means many, a large number-probably referring to its many granular roots.

Chryosplenium oppositifolium - Golden saxifrage. Gaelic: lus nan laogh (the same for Sedum telephium). Irish: clabrus, from clabar, mud, growing in muddy places; gloiris, from gloire, glory, radiance,-another name given by the authorities for the "golden saxifrage;" but they probably mean Saxifraga aizoides, a more handsome plant, and extremely common beside the brooks and rivulets among the hills.

1 This is what I always heard it called; but M'Donald gives norn, and in the Highland Society's Dictionary it is given creamh-garaidh, evidently a translation by the compilers, as they give the same name to the Leek.FERGUSSON. 
Parnassia palustris - Grass of Parnassus. Shaw gives the name fionnsgoth (fionn, white, pleasant, and sgoth, a flower), "a flower," but he does not specify which. Finonan geal has also been given as the name in certain districts, which seems to indicate that fionnsgoth is the true Celtic name.

\section{Araliacee.}

Hedera- "Has been derived from hedra, a cord, in Celtic" (Loudon).

Hedera helix-Ivy. Gaelic : eidheann, that which clothes or covers (from eid, to clothe, to cover); written also eigheann (eige, a web), eidhne, eitheann.

"Spionn an eitheann o'craobh."-OLD PoEM.

Tear the ivy from the tree.

"Eitheann nan crag."-Ossian.

The rock-ivy.

"Briseadh tro chreag nan eidheann dlu"

Am fuaran ùr le torraman trom."-MIANN A BHARD AOSDA.

Let the new-born gurgling fountain gush from the ivy-covered rock.

Faithleadgh, Irish : faithlah, that which takes hold or possession. Welsh : iiddere (from eiddiaze, to appropriate). Irish : aighneann (from aighne, affection), that which is symbolic of affection, from its clinging habit. Gort, sour, bitter-the berries being unpalatable to human beings, though eaten by birds. Ialluin (from iall, a thong, or that which surrounds); perhaps from the same root as helix. Greek: $\epsilon_{\imath} \lambda \lambda^{\prime} \omega$ (eileo, to encompass); also iadhshlat, the twig that surrounds, - a name likewise given to the honeysuckle (Lonicera periclymenum), because it twines like the ivy-

"Mar iadh-shlat ri stoc aosda."

Like an ivy to an old trunk.

An gàth, a spear, a dart.

The badge of the Clan Gordon.

\section{CORNACEe.}

Cornus (from Latin : cornu, a horn). Gaelic: corn. French : corvie. "The wood being thought to be hard and durable as horn."

Cornus sanguinea-Dogwood, cornel-tree. Gaelic: coin-bhil, dogwood; conbhaiscne, dog-tree (baiscne, Irish, a tree). Irish: crann coirnel, cornel-tree. 
C. suecica-Dwarf cornel,-literally, Swedish cornel. Gaelic and Irish : lus-a-chraois, plant of gluttony (craos, a wide mouth; gluttony, appetite). "The berries have a sweet, waterish taste, and are supposed by the Highlanders to create a great appetite,-whence the Erse name of the plant" (Stuart of Killin).

\section{UMBELLIFER尤.}

Hydrocotyle vulgaris-Marsh pennywort. Gaelic: lus na peighinn, the pennywort. Irish: lus na pinghine (O'Reilly), from the resemblance of its peltate leaf to a peighinn,-a Scotch penny, or the fourth part of a shilling sterling.

Eryngium maritimum-Sea-holly. Gaelic and Irish : cuileann tràgha, sea-shore holly. (See Ilex aquifolium). Welsh: y môr gelyn, sea-holly (celynen, holly).

Sanicula europæa-Wood sanicle. Gaelic : bodan coille, woodtail,-the little old man of the wood. Irish : caogma,-caog, to wink. Buine, an ulcer,-a noted herb, "to heal all green wounds speedily, or any ulcers. This is one of Venus, her herbs, to cure either wounds or what other mischief Mars inflicteth upon the body of man" (Culpepper). Welsh : clust yr arth, bear's-ear.

Conium maculatum-Hemlock. Gaelic: minmhear (Shaw), - smooth or small fingered, or branched, in reference to its foliage; mongach mhear, and muinmhear, - mong and muing, a mane, from its smooth, glossy, pinnatifid leaves. Minbhar, softtopped or soft-foliaged. Iteodha, iteotha,-ite, feathers, plumage. The appearance of the foliage has evidently suggested these names, and not the qualities of the plant, although it is looked upon still with much antipathy.

"Is coslach e measg chaich

Ri iteodha an garadh."-M'INTYRE.

Among other people he is like a hemlock in a garden.

" Mar so tha breitheanas a' fàs a nìos, mar an iteotha ann claisibh na machrach."-Hos. x. 4 .

Thus judgment springeth up like a hemlock in the furrows of the field.

Welsh : gzoin dillad, pain-killer. Manx : aghue.

"Ta'n aghue veg shuyr da'n aghue vooar."-MANX Proverb.

The little hemlock is sister to the big hemlock.

(A small sin is akin to the great one.)

Cicuta virosa - Water-hemlock. "The hemlock given to prisoners as poison" (Pliny); and that with which Socrates was poisoned. Gaelic and Irish : fealla bog, the soft deceiver; feall, 
treason, falsehood; and feallair (feall flear), a deceiver,-from the some root (Latin, fallo, to deceive). Welsh : cegid. Latin : cicuta.

Smyrnium olusatrum - Alexanders. Gaelic: lus nan grìn dubh, the plant with black seeds, - on account of its large black. seeds. It was formerly eaten as a salad or pot-herb, whence, and from its blackness, the name olusatrum (Latin : olus, a vegetable, and ater, black). " "Alexanders,' because it was supposed to have been brought from Alexandria " (Ray).

Apium (from Celtic root, $a b h$, a fluid or water, Latinised into apium).

Apium graveolens - Smallage, wild celery. Gaelic: lus na smalaig, a corruption of smallage. Pearsal mhor, the large parsley. Irish : meirse. Greek : $\mu \epsilon \iota \rho a$, to divide ; or Anglo-Saxon : merse, a lake, sea. Latin : mare,-marshy ground being its habitat. Welsh : persli frengig, French parsley.

Petroselinum sativum-Parsley. Gaelic : pearsal (corruption from the Greek, $\pi \epsilon \tau \rho o s$, petros, a rock, and $\sigma \epsilon \lambda \iota v o v$, sclinon, parsley). Muinean Mhuire, Mary's sprouts. Welsh : persli.

Heliosciadium inundatum - Marshwort. Gaelic : fualactar (from fual, water). The plant grows in ditches, among water.

Carum carui-Caraway. Scotch : carvie; Gaelic: carbhaidh (a corruption from the generic name), from Caria, in Asia Minor, because it was originally found there;-also written carblizin.

"Cathair thalmhanta's carbhinn chroc cheannach."-M 'INTYRE.

The yarrow and the horny-headed caraway.

Lus Mhic Chuimein, M'Cumin's wort. The name is derived from the Arabic gamoun, the seeds of the plant Cuminum cyminum (cumin), which are used like those of caraway.

Bunium flexuosum-The earth-nut. Gaelic: braonan bluachail, the shepherd's drop (or nut); braonan bachlaig (Shaw); cno thalmhainn,-cno, a nut, thalmhainn, earth,-ploughed land, ground. (Hebrew : תל, talam, tilim, ridges, heaps; as into ridges or furrows, -heap up. I atin : tellus. Arabic: tèl). Irish: caor thalmhainn, earth-berry; coirearan muic, pigberries, or pig-nuts. Cutharlan, a plant with a bulbous root.

Fœniculum vulgare-Fennel. Gaelic: lus an t'saiodh, the hayweed. Fineal, from Latin, fonum, hay, - the smell of the plant resembling that of hay. Irish : funeal chumhthra (cumhra, sweet, fragrant). Welsh: ffenigl.

Ligusticum, from Liguria, where one species is common. 
Ligusticum scoticum-Lovage. Gaelic: siunas, from sion, a blast, a storm,- - growing in exposed situations. In the Western Isles, where it is frequent on the rocks at the sea-side, it is sometimes eaten raw as a salad, or boiled as greens.

Levisticum officinale ${ }^{1}$-Common lovage. Gaelic: luibh an lingair, the cajoler's weed. It was supposed to soothe patients subject to hysterics and other complaints. Irish: lus an liagaire, the physician's plant, from which the Gaelic name is a corruption. Welsh : dulys, the dusky plant.

Meum athamanticum-Meu, spignel, baldmoney. Gaelic: muilceann. Scotch: micken, -muilceann ${ }^{2}$ possibly from muil, a scent; muleideachd, a bad smell (Shaw); ceam, a head or top. The whole plant is highly aromatic, with a hot flavour like lovage. Highlanders are very fond of chewing its roots.

Angelica-(So named from the supposed angelic virtues of some of the species).

A. sylvestris-Wood angelica. Gaelic: lus nam buadha, the plant having virtues or powers. Cuinneog mhighe, the whey bucket. Galluran, perhaps from gall (Greek: gala), milk, from its power of curdling milk; for this reason, hay containing it is considered unsuitable for cattle. Irish : contran. Aingcalag: angelica.

Crithmum maritimum-Samphire. Gaelic: saimbhir, a corruption of the French name St Pierre (St Peter), from Greek, $\pi$ té $p a$, a rock or crag. (The samphire grows on cliffs on the shore). Gaelic: lus nan cnàmh, the digesting weed; niàmh (from Greek: $\chi v a \omega ;$ Welsh : cnoi; Irish : cnaioi), chew, digest. The herb makes a good salad, and is used medicinally. Irish : grioloigin,-_griol, to slap, to strike.

Peucedanum ostruthium-Great masterwort. Gaelic: mor flitiodh (Armstrong), the large excrescence, or the large chickweed.

P. officinale-Hog-fennel or sow-fennel. Gaelic: fineal sraide (Shaw),-sraide, a lane, a walk, a street. This plant is not found in Scotland, but was cultivated in olden times for the stimulating qualities attributed to the root.

${ }^{1}$ Levisticum, from Latin, levo, I assuage.

2 In Invernesshire, bricin or bricin dubh, perhaps from bri, juice; or, as mentioned in Lightfoot, vol. i. p. 158, as Sibbald says it grows on the banks of the Breick Water in West Lothian, may not some native of the banks of the Breick have given it this local name in remembrance of seeing it growing on the banks of his native Breick?-FERGUSSON. 
Anethum graveolens - Strong-scented or common dill. Gaelic and Irish : dile (M'Donald) (Latin: diligo), 一 dile, a word in Gaelic meaning love, affection, friendship. The whole plant is very aromatic, and is used for medicinal preparations.

Sium (from siu, "water in Celtic," I.oudon), perhaps from sjo (Gothic), water, lake, sea.

S. sisarum-Skirrets. Gaelic : crumagan (Shaw), from crom, bent, crooked, from the form of its tubers. The tubers were boiled and served up with butter, and were declared by Worlridge, in 1682 , to be "the sweetest, whitest, and most pleasant of roots;" formerly cultivated in Scotland under the name of "crummock," a corruption of the Gaelic name.

S. angustifolium-Water-parsnip. Gaelic : folachdan (Armstrong), from folachd, luxuriant vegetation; an, water. Irish : cosadh dubhadh, the great water-parsnip (O'Reilly), (cos, a foot, stalk, shaft, and dubh, great, prodigious).

Pastinaca sativa - Parsnip. Gaelic: meacan-an-righ, the king's root, royal root. Curran geal (from cur, to sow, geal, white). Irish: cuiridin ban, the same meaning (cuirim, I plant or sow). Welsh : moron gze'ynion, field-carrot.

Ægopodium podagraria - Goat-, gout-, or bishop-weed. Gaelic: lus an easbuig,-easbuig, a bishop. A name also given to Chrysanthemum leucanthemum, but with a different signification.

Heracleum sphondylium - Cow-parsnip. Gaelic : odharan, from odhar (Greek: wxpos; English: ochre), pale, dun, yellowish, in reference to the colour of the flower. Meacan-a-chruidh, the cow's plant: The plant is wholesome and nourishing for cattle. Gunnachan sputachain, squirt-guns. Children's name for the plant, because they make squirt-guns from its hollow stems.

Daucus carota-Carrot. Gaelic : curran (from cur, to sow), a root like that of the carrot. Carrait, corruption from carota, which is said to be derived from the Celtic root car, red, from the colour of the root. Muran-(Welsh: moron), a plant with tapering roots. Irish : curran bhuidhe, the yellow root.

"Muran brioghar 's an grunnasg lionmhar."-M'INTYRE.

The sappy carrot and the plentiful groundsel.

Irish: mugoman,-mugan, a mug, from the hollow bird's-nestlike flower.

Anthriscus

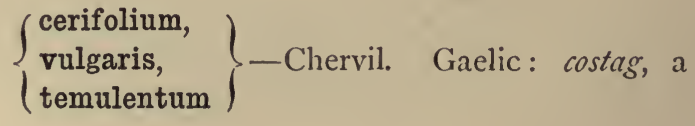


common name for the chervils (from cost, an aromatic plant; Greek: кóoros, kostos, same meaning). Costag a bhaile gheamhraidh (bhaile gheamhraidh, cultivated ground). "A. i'ulgaris was formerly cultivated as a pot herb" (Dr Hooker).

Myrrhis (from Greek: $\mu v \rho o v$, myron, perfume; Gaelic: mirr, -tus agus mirr, frankincense and myrrh).

M. odorata-Sweet cicely or great chervil. Gaelic : cos wisge (Shaw), the scented water-plant." "Sweet chervil, gathered while young, and put among other herbs in a sallet, addeth a marvellous good relish to all the rest" (Parkinson).

Coriandrum (a name used by Pliny, derived from корьs, coris, a bug, from the fetid smell of the leaves).

C. sativum-Coriander. Gaelic : coireiman,-lus a choire, corruptions from the Greek. It is still used by druggists for various purposes, and by distillers for flavouring spirits.

\section{LORANTHACEE.}

Viscum album - Mistletoe. Gaelic and Irish: uilé-ice (uile, Welsh: hall or all; Goth.: alls; German : aller; A. S.: eal ; English : all; ice, Welsh : iarc, a cure or remedy), a nostrum, a panacea (M'Donald), all-heal. Armoric: all-yiach. Welsh : oll-iach. Irish : wile iceach. This is the ancient Druidical name for this plant. Pliny tells us, "The Druids (so they call their Magi) hold nothing in such sacred respect as the mistletoe, and the tree upon which it grows, provided it be an oak. ' Omnia sanantem appellantes suo vocabulo.' (They call it by a word signifying in their own language All-heal.) And having prepared sacrifices, and feast under the tree, they bring up two white bulls, whose horns are then first bound; the priest, in a white robe, ascends the tree, and cuts it off with a golden knife; it is received in a white sheet. Then, and not till then, they sacrifice the victims, praying that God would render $\mathrm{His}$ gift prosperous to those on whom $\mathrm{He}$ had bestowed it. When mistletoe is given as a potion, they are of opinion that it can remove animal barrenness, and that it is a remedy against all poisons." Druidh-lus, the Druid's weed. "The proper etymology is the ancient Celtic vocable $d r u$, an oak, from which $\delta \rho v s$ is taken" (Armstrong). Siigh dharaich, the sap or substance of the oak, because it derives its substance from the oak, it being a parasite on that and other trees. (Siigh, juice, sub-

${ }^{1}$ In Braemar it is commonly called mirr.-ED. 'Scottish Naturalist.' 
stance, sap; Latin : succus). Irish : guis, viscous, sticky, on account of the sticky nature of the berries. French : gui.

\section{CAPRIFOLIACEE.}

Sambucus nigra - Common elder. Gaelic and Irish: ruis, meaning "wood." "The ancient name of the tree, which in the vulgar Irish is called trom" (O'Reilly); druman or droman (Sanscrit: dru, wood, tree ; drumas, wood). Welsh: ysgazen, elder.

S. ebulus-Dwarf elder. Gaelic and Irish: fliodh a bhalla, the wall excrescence. Mulart "seems to be the same as the Welsh word mieyllartaith (meyll, emollient, and artaith, torment ") (Brockie). It was esteemed a powerful remedy for the innumerable ills that flesh is heir to. Mulabhar (mu?, a multitude, and bar, top) may only be a corruption of mulart. The specific name is from $\epsilon v \beta o \lambda \eta$, eubiole, an eruption. Welsh: ysgazen Mair, Mary's elder.

Viburnum opulus - Guelder - rose, Water-elder. Gaelic :

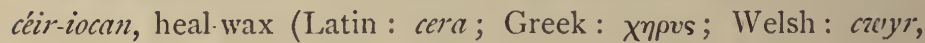
wax), the healing, wax like plant, from the waxy appearance of the flowers.

V. lantana - Wayfaring tree. Gaelic : craobh fiadhain (Armstrong), the wild or uncultivated tree.

Lonicera periclymenum-Woodbine, honeysuckle. Gaelic: uillean (elbows, arms, joints) elbow-like plant; feith, feithlean. Irish : feathlog, fethlen, from feith, a sinew, tendon, suggested by its twisting, sinewy stems. Lus na meala, the honey-plant, from mil (Greek: $\mu \epsilon \lambda_{\iota}$; Latin: mel), honey. Deolag, or deoghalag, from deothail, to suck. Irish : cas fa chrann, ${ }^{1}$ that which twists round the tree. Baine gamhnach (O'Reilly), the yearling's milk. A somewhat satirical name, implying that the sucking will produce scanty results. In Gaelic, iadh shlat is frequently applied both to this plant and to the ivy (see Hedera helix). Welsh : gz'yddfid, tree-climber or hedge-climber.

\section{RUBIACEE.}

Rubia tinctorum-Madder. Gaelic : madar (Armstrong).

Galium aparine-Goose-grass; cleavers. Gaelic: garbh lus,

1 In Strathardle and many other districts, leum-a-chrann (leum, jump, crann, a tree) alluding to its jumping or spreading from tree to tree. High. Soc. Dict. gives duilliur-fìthlean, probably from its darkening whatever grew under it.-FERGUSSON. 
the rough weed. Irish : airmeirg, from airm, arms, weapons, from its stem being so profusely armed with retrograde prickles.

G. saxatile (Armstrong) - Heath bedstraw. Madar fraoch, heath madder. It grows abundantly among heather. O'Reilly gives this name also to $G$. verum.

G. verum-Yellow bedstraw. Ruin, manh, from madh, red. "The Highlanders use the roots to dye red colour. 'Their manner of doing so is this: The bark is stripped off the roots, in which bark the virtue principally lies. They then boil the roots thus stripped in water, to extract what little virtue remains in them; and after taking them out, they last of all put the bark into the liquor, and boil that and the yarn they intend to dye together, adding alum to fix the colour" (Lightfoot).

Lus an leasaich (in Glen Lyon) the rennet-weed. "The rennet is made as already mentioned, with the decoction of this herb. The Highlanders commonly added the leaves of the Urtica dioica or stinging-nettle, with a little salt" (Lightfoot). Irish: baladh chnis (O'Reilly), the scented form (baladh, odour, scent, cneas, form).

Asperula odorata-Woodruff. Gaelic: lusa-caitheamh. ${ }^{1}$ Probably the Irish name baladh chnis, the scented form, is the woodruff, and not the lady's bedstraw; it is more appropriate to the former than to the latter.

\section{VALERIANACE\&.}

Valeriana officinalis-Great wild valerian. Gaelic: an tribhileach (M'Kenzie); lus na tri bhilean (Armstrong), the three-leaved plant, from the pinnate leaves and an odd terminal one, forming three prominent leaflets. Irish : lus na tri ballan, the plant with three teats (ballan, a teat); perhaps from its three prominent stamens (Brockie); carthan curaigh (carthan, useful, curaigh, a hero, a giant)-i.e., the useful tall plant. Welsh: $y$ llysiezeyn, the beautiful plant; y dri-aglog (dri, three, aglog, burning; from its hot bitter taste).

V. dioica-Marsh or dwarf valerian. Irish : curthan arraigh, from arrach, dwarf; caoirin leana, that which gleans in the marsh (caoir, gleams, sparks, flames, flashes; leana, a swamp, a marsh). Although this plant is not recorded from Ireland, yet the names only occur in the Irish Gaelic.

1 Lusa-caitheamh, the consumption herb, as it was much used for that disease. -FERGUSSON. 


\section{DIPSACEE.}

Dipsacus sylvestris ( Teasel,

fullonum $\}$ Teasel, or fuller's teasel. Gaelic: leadan,-liodan; liodan an fhucadair (leadan or liodan, a head of hair, fucadair, a fuller of cloth); used for raising the nap upon woollen cloth, by means of the hooked scales upon the heads of the fuller's teasel. Irish : taga. Welsh : llysie y cribef, carding plant, from crib, a comb, card.

Scabiosa succisa - Devil's bit scabious. Gaelic and Irish : ura bhallach (ur, fresh, new ; ballach, from ball, a globular body, from its globular-shaped flower-heads, or ballach, spotted. This old Celtic word is found in many languages. Greek: $\beta a \lambda \lambda \omega$. German: ball.) Urach mhullaich, bottle-topped (urach, a bottle, from the form of the flower-head; mullach, top). Odharach mhullaich, a corruption of urach. (Odhar means dun or yellowish, but the flower is blue). Greim an diabhail (O'Reilly), devil's bit, from its præmorse root, the roots appearing as if bitten off. According to the old superstition, the devil, envying the benefits this plant might confer on mankind, bit away a part of the root, hence the name. Welsh : y glafrllys, from clafr, clazer, scab, mange, itch; translation of scabiosa, from scabies, the itch, which disorder it is said to cure.

Knautia arvensis-Corn-field knautia (so named in honour of C. Knaut, a German botanist) or field scabious. Gaelic: gille guimein, the blue lad. Irish: caba deasain, the elegant cap; caba, a cap or hood; and dects, neat, pretty, elegant. Bodach gorm, the blue old man.

\section{CoMposite.}

Helminthia echioides - Ox-tongue. Gaelic: boglus (Armstrong), a corruption from the Irish; bolglus, ox-weed, from bolg, a cow, an ox. A name also given to Lycopsis arvensis. Bog luibh, same meaning.

Lactuca sativa-Lettuce. Gaelic and Irish : liatus, lettuce, a corruption from lactuca (Latin : lac, milk), on account of the milky sap which flows copiously when the plant is cut; luibh inite, the eatable plant. Irish: billeog math, the good leaf. Welsh : gzoylath, guyfluid, lacth, wilk.

Sonchus oleraceus - Common sow - thistle, milk - thistle. Gaelic and Irish: bog ghioghan, the soft thistle. Irish: giogan, a thistle. Baine muic, sow's milk. 
S. arvensis-Gaelic : blioch fochain, the corn milk-plant; blioch, milky; fochan, young corn. IVelsh : llaeth ysgallen, milk-thistle (ysgallen, a thistle).

Hieracium pilosella-Mouse-ear hawkweed. Gaelic: cluas luch, mouse-ear; cluas liath, the grey ear.

H. murorum-Wall hawkweed. Irish : srubhan na muc, the pig's snout (srubli, a snout).

Taraxacum dens-leonis-Dandelion. Gaelic : bearnan bride.

"Am bearnan bride s'a pheighinn rioghil."-M'INTYRE.

The dandelion and the penny-royal.

Bearn, a notch, from its notched leaf; bride, ${ }^{1}$ from brigh, sap, juice, with which the plant abounds; bior nam bride (bior, sharp, tooth-like); facal leomhain, lion's teeth. Welsh : dant y llew, the same meaning as dandelion (dent de lion) and leontodon $(\lambda \epsilon \omega \nu$, a lion ; and odovs, a tooth), from the tooth like formation of the leaf. Castearbhan nam muc (Shaw)-The pig's sour-stemmed plant. Irish : caisearbhan, cais-t'searbhain, castearbhan (cais, a word of many significations, but here from cas, a foot; caiseas, the stem of a plant; searbh, bitter, sour).

Cichorium intybus-Succory or Chicory. Gaelic: lus an tsuicair, a corruption from cichorium, which was so named from the Egyptian word chikoiryeh. Pliny remarks that the Egyptians made their chicory of much consequence, as it or a similar plant constituted half the food of the common people. It is also called in Gaelic castearbhan, the sour-stemmed plant.

C. endiva-Endive. Gaelic : enach ghàraidh (enach, corruption of endiva, "from the Arabic name hendibeh" (Du Théis), gàradh, a garden). Welsh : ysgali y meirch, horse-thistle.

Lapsana communis-Nipple-wort. Gaelic: duilleag mhaith, the good leaf; duilleag mhin, the smooth leaf. Irish: duilleog bhrighid, the efficacious leaf, or perhaps St Bridget's leaf, the saint who, according to Celtic superstition, had the power of revealing to girls their future husbands. French: herbe aux mamelles, having been formerly applied to the breasts of women. to allay irritation caused by nursing. Duilleog bhraghad, or braighe, the breast-leaf.

1 "Most certainly bride comes from its being in flower plentifully on latha flieill-bricte."-FERGUSSON.

Bride is also a corruption of Bbrighit, St Bridget. Latha Fheill-Brighte, Candlemas, St Bridget's Day. 
"Tha do phòg mar ùbhlan garaidh,

's tha do bhraighe mar an neoinean." - M'INTYRE, Oran Gaoil.

Thy kiss is like the apples of the garden,

And thy bosom like the daisy.

"If it was used by the French for rubbing the breasts, nothing seems more likely than that it would be also so used by the Celts of Ireland and Scotland, which would at once give it the name of dulleog braghad" (Fergusson).

Arctium-Celtic: art, a bear. Greek : арктоs, from the rough bristly hair of the fruit.

A. lappa-Burdock. Gaelic and Irish : suirichean suirich, the foolish wooer (suiriche, a fool ; suirich, a lover or wooer); seirceun suirich, affectionate wooer (seirc, affection). Mac-an-dogha, 1 the mischievous plant (mac-an for meacan, a plant); doghadh, mischievous (Shaw). Meacan-tobhach-dubh, the plant that seizes (tobhach, wrestling, seizing, inducing; $d u b h$, black, or large). Leadan liosda (leadan, a head of hair ; liosda, stiff). Irish : copag tuaithil, the ungainly docken; ccosan, the bur, or fruit.

"Mar cheosan air sgiathan fhirein."-Ossian.

Like bur clinging to the eagle's wing.

Welsh : cynyhau, closely packed. Cribe y bleidd, wolf's comb. Caca muci, puck's dung. Lappa, from Celtic, llap (Loudon). Gaelic (for hand) limh. Welsh: llamh.

Carduus heterophyllus-Melancholy thistle. Gaelic: cluas an fheidh, the deer's ear.

C. palustris-Marsh-thistle. Gaelic : chuaran leana (cluaran, a thistle; lean, a swamp);

"Lubadh cluaran mu Lora nan sion."-Ossian.

Bending the thistle round Lora of the storms.

Charan, a general name for all the thistles. Welsh: y's gallen.

C. lanceolatus-Spear-thistle. Gaelic: an cluaran deilgneach, the prickly thistle (deilgne, prickle-thorn).

C. arvensis-Corn-thistle. Gaelic: aigheannach, the valiant one (from aighe, stout, valiant).

C. marianus-Mary's thist'e. Gaelic: fothannan beannuichte. Irish : fothannan beandicighte (Latin: benedictus), the blessed thistle (so called from the superstition that its leaves are stained with the Virgin Mary's milk); fothannan, foghnan, fonndan, a thistle. Danish : fön, thistle-down.

I Dogha also means burnt or singed. It was formerly burned to procure from its ashes a wbite alkaline salt, as good as the best potash. 
"Leannaibh am foghnan."-Ossian.

Pursue the thistle-down.

"'Feadh nan raointean lom ud, Far nach cinn na fotl'nain."

Among these bare hillsides,

Where the thistles will not grow.

M'Donald has another name, cluaran oir, the gold thistle.

"Gaoir bheachainn bhùi 's ruadha

Ri deoghladh chluaran oir."

The buzzing of yellow and red wasps

Sucking the golden thistle.

It is uncertain to which thistle, if any, the reference is made, unless it be to Carlina vulgaris, the carline thistle. Cluaran, occasionally means a daisy, Chrysanthemum segetum, one of its names being liathan.

"Liath chluaran nam magh."-OSsiAN.

The hoary thistle (or daisy) of the field.

Here the reference is evidently to the corn-marigold; in all probability M'Donald refers to the same flower, and not to any thistle (see Chrysanthemum segetum).

The thistle, the badge of the Clan Stewart.

Cynara scolymus-Artichoke. Gaelic : farusgag, from farusg, the inner rind, the part used being the lower part of the receptacle of the flower, freed from the bristles and seed-down, and the lower part of the leaves of the involucre. Bliosan, not unlikely to be a contraction from bli-liosan,-bli (bligh), milk (with its florets milk was formerly coagulated); and lios, a garden. These names apply also to Helianthus tuberosus, Jerusalem artichoke, especially to the tubers; and plur na greine, to the flower, from the popular error that the flower turns with the sun.

Centaurea nigra-Knapweed. Gaelic: cnapan dubh, the black knob (from cnap, a knob; Welsh, Armoric, and Irish : cnap; Saxon: cnap; Danish cnap.) Mullach dubh, the black top. Irish: niansgoth, the daughter's flower (nian, a daughter; sgoth, a flower).

C. cyanus-Blue-bottle. Gaelic: gorman, the blue one. In some places, gille-guirmean, the blue lad. Curachd chubhaig, the cuckoo's cap or hood. Irish : curac na cuig, the same meaning. Welsh: penlas zeen, blue headed beauty.

Artemisia vulgaris-Mugwort. Gaelic: liath lus, the grey weed. Mor manta (Shaw), the large demure-looking plant (mor, 
large ; manta, demure, bashful). Mughard, Mugwort (mugan, in Irish, a mug, or mugart, a hog). Irish: bofulan ban, or buafannan bdn, the white toad, or serpent (buaf, a toad; buafa, a serpent ; Latin: bufo, a toad); buafannan liath, the grey toad or serpent. Welsh : llweydlys, grey weed:

A absinthium-Common wormwood. Gaelic: buramaide. Irish : borramotor, also burbun (burrais, a worm or caterpillar; maide, wond)-i.e., wormwood. Searbh luibh, bitter plant.

"Chuir e air mhisg ma le searbh-luibhean."-STUART.

He hath made me drunk with wormwood.

"Mar a bhurmaid."

Like the wormwond.

It was formerly used instead of hops to increase the intoxicating quality of malt liquor. Roide, gall, bitterness. Graban (from Gothic, grub, dig). ${ }^{1} \quad$ Welsh: bermod chwernelys, bitter weed.

A. abrotanum - Southernwood. Gaelic: meath chaltuinn. (Meath, Latin mitis, faint, weary, effeminate. Its strong smell is said to prevent faintness and weariness. Caltuinn, from call, Latin : cald; Italian: cala; French : cale, a bay, sea-shore, a harbour.) It grows in similar situations to $A$. maritima. Irish : surabhan, suramont, and Welsh, sizedrmat. The sour one (sirr, sour), and "southernwood," also from the same root. Welsh: llysier cyrff, ale-wort (cyrff, Latin, cervisia, ale), it being fre"quently used instead of hops to give a bitter taste to malt liquors.

Gnaphalium dioicum, G. sylvaticum - Cudweed. Gaelic: cat luibh, the cat's weed. Gnibh, or cnamh lus, the weed that wastes slowly (from rvaфádıov), a word with which Dioscorides describes a plant with white soft leaves, which served the purpose of cotton. This well describes these plants. They have all beautifully soft woolly leaves; and, on account of the permanence of the form and colour of their dry flowers, are called "Everlasting."

Filago germanica-Common cotton rose. Gaelic and Irish : liath lus roid, the gall (or wormwood) grey weed.

1 The occasional occurrence of Gothic roots in plants' names in the Western Highlands and Isles, is accounted for by the conquest of these parts by the Norwegians in the ninth century, and the fact of their rule existing there for at least two centuries under the sway of the Norwegian kings of Man and the Isles. 
Petasites vulgaris-Butter-bur, pestilence-wort. Gaelic and Irish : gallan mor, the big branch, possibly referring to its large leaf. Greek: yadavos, mast. Danish: galan, a stripling. Pobal, more correctly pubal. Welsh : pabel, a tent, a covering.

\section{"Shidhich iad am pubuill."-Ossian. \\ They pitched their tents.}

The Greek name, $\pi \epsilon \tau a \sigma o s$, a broad covering, in allusion to its large leaves, which are larger than that of any other British plant, and form an excellent shelter for small animals.

Tussilago farfara-Colt's foot. Gaelic: chuas liath, grey ear; gorm liath, greyish green; duilliur spuing, the tinder-leaf.

"Cho tioram ri spuing."

As dry as tinder.

The leaf, dipped in saltpetre and then dried, made excellent tinder or touchwood. Gaelic and Irish : fathan or athan, meaning fire. It was used for lighting fire. The leaves were smoked before the introduction of tobacco, and still form the principal ingredient in the British herb tobacco. Gallan-greannchair (gallan, see "Petasites;" greann, hair standing on end, a beard), probably referring to its pappus. Irish : cassachdaighe (O'Reilly), a remedy for a cough (casachd, a cough; aighe or ice, a remedy). "The leaves snoked, or a syrup or decoction of them and the flowers, stand recommended in coughs and other disorders of the breast and lungs" (Lightfoot). Welsh : carn y ebol (carn, hoof, and ebol, foal or colt), colt's-foot.

Senecio vulgaris-Groundsel. Gaelic: am bualan, from bual, a remedy. Lus Phàra liath, ${ }^{1}$ grey Peter's-weed, a name suggested by its aged appearance, even in the spring-time. Latin: senecio. Welsh : ben-felan, sly woman. Sail bhuinn (sail, a heel; buinn, an ulcer). "The Highlanders use it externally in cataplasms as a cooler, and to bring on suppurations" (Lightfoot). Grunnasg (from grunnd, ground; German : grund). Welish : grunsel.

"Muran brioghar s'an grunnasg lionmhor."-M'INTYRE.

The sappy carrot and the plentiful gioundsel.

Irish: crann lus, the plough-weed. Buafanan na h' easgaran

1 In Breadalbane, Glenlyon, and other places, the plant is called Lus Phàra liath-

"Lus Phara liath cuiridh e ghoimh as a chraimh."

The groundsel will extinguish acute pain in the boneit being frequently applied as a cure for rheumatic pains. 
(buaf, a toad, a serpent, but in this name evidently a corruption from bualan, a remedy, or buadh, to overcome; easgaran, the plague), a remedy for the plague. A name given also to the ragwort.

S. Jacobæa-Ragwort. Gaelic and Irish : buadhlan buidhe (from buadh, to overcome; buidhe, yellow); buadhghallan, the stripling or branch that overcomes; guiseag bhuidhe, or cuiseag, the yellow-stalked plant; cuiseag, a stalk. Welsh : llysiu'r ysgyfarnog, the hare's plant; llysiu'r nedir, the serpent's weed -agreeing with one of its Irish names, buafanan,-buaf, a serpent or toad.

Inula Helenium - Elecampane, said to be from the officinal name, inula campana, but probably a corruption of Helénula, Little Helen (Jones). Greek : $\dot{\epsilon} \lambda \epsilon \nu$ s, the elecampane. Gaelic: àillean, from àille, beautiful, handsome. Irish : Ellea (Gaelic, Eilidh), Helen. The famous Helen of Troy, who is said to have availed herself of the cosmetic properties of the plant. Creamh, sometimes, but more generally applied to Allium ursinum (which see).

Bellis perennis-Daisy. Gaelic and Irish: neoinan, or noinean, the noon-flower (from noin, noon; Welsh : nazon; Latin: nona, the ninth hour, from novem, ninth. The ninth hour, or three in the afternoon, was the noon of the ancients).

"'San neinean beag's mo lamh air cluin."-Mian A BHARd AOSDA. And the little daisy surrounding my hillock.

Buidheag (in Perthshire), the little yellow one.

"Geibh sinn a bhuidheag san lòn."-OLD Song.

We shall find the daisy in the meadow.

Gugan (Armstrong), a daisy, a bud, a flower.

Chrysanthemum segetum - Corn-marigold. Gaelic: bile buidhe, the yellow blossom. Bileach choigreach, the stranger or foreigner. Liathan, Irish, lia, the hoary grey one (from Greek $\lambda \epsilon \hat{\imath}$ os; Welsh: llwoyd), on account of the light-grey appearance of the plant, expressed botanically by the term glaucous. $A n$ dithean oir, the golden flower, or chrysanthemum ( $\chi \rho v \sigma o s$, gold;

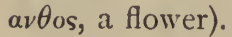

"Mar mhin-chioch nan ò dhithean beag."

Like the tender breast of the little marigold.

"Do dhithean lurach luaineach

Mar thuarneagan de'n 'òr."-M'Donald.

Thy lovely marigolds like waving cups of gold. 
Dithcan is frequently used in a general sense for "flower," also for "darnel."

$$
\begin{aligned}
& \text { "Tir nan dithean miadar daite." } \\
& \text { Land of flowers, meadow dyed. } \\
& \text { "Dithein nan gleann." } \\
& \text { The flowers of the valley. }
\end{aligned}
$$

Welsh : gold mair, marigold. Irish : buafanan buidhe, the yellow toad.

C. leucanthemum-Ox-eye. Gaelic: an neonan mor, the big daisy. Am bréinean-brothach ${ }^{1}$ (bréine, stench; brothach, scabby). Easbuigban, from Irish easbudh, silly, idle (easbudh brothach, the King's-evil). This plant was esteemed an excellent remedy for that complaint. Irish : easbuig speain (Speain or Easbain, Spain).

Anthemis nobilis-Common chamomile. Camomhil, from the Greek $\chi a \mu \alpha \iota \mu \eta \lambda o s$, which Pliny informs us was applied to the plant on account of its smelling like apples. (Spanish : mancinilla, a little apple.) Lus-nan-cam-bhil (M'Kenzie), the plant with drooping flowers. The plant is well distinguished by its flowers, which droop, or are bent dozen, before expansion; but though the name is thus applicable, it is only a corruption from the Greek.

\footnotetext{
"Bi'dh mionntain, camomhil s'sobhraichean

Geur bhileach, lonach, luasganach."-M'INTYRE.

There will be mints, chamomile, and primroses, Sharp-leaved, prattling, restless.
}

Luibh-leighis, the healing plant. This plant is held in considerable repute, both in the popular and scientific Materia Medica.

A. pyrethrum-Pellitory of Spain. Gaelic: lus na Spaine, the Spanish weed.

A. arvensis-Field chamomile. Irish: coman mionla (coman, a common; mionla, fine-foliaged. Gaelic: min lach).

Matricaria inodora_-Scentless May-weed. Gaelic: buidheag an arbhair, the corn daisy. Camomhil feadhain, wild chamomile. Welsh : llygad yr ych, ox-eye.

Tanacetum vulgare - Tansy. Gaelic: lus na Fraing, the French weed. (French, tanaisie.) Irish : tamhsae, corruptions from Athanasia. (Greek: a, privative, and Oavaros, death, i.e., a plant which does not perish-a name far from applicable to this species).

Eupatorium cannabinum - Hemp agrimony. Gaelic and

1 Breinean-brothach was probably also applied to $A$. cotula, for which there is no Gaelic name recorded. 
Irish: cnaib uisge or caineab uisge, water-hemp (from Greek кavvaßıs; Latin, cannabis, hemp; the root can, white).

Bidens cernua-Bur marigold. Irish : sceachog Mhuire, Mary's haw.

Achillea ptarmica-Sneezewort. Gaelic: cruaidh lus, hard weed. (Latin : crudus, hard, inflexible). Meacan ragaim, the stiff plant. Roibhe, moppy.

A. millefolium-Yarrow. Gaelic: lus chosgadh na fola, the plant that stops bleeding. Lus na fola, the blood-weed. Earr thalmhainn, that which clothes the earth (earr, clothe, array). Athair thalmhainn, the ground father. Cathair thalmhainn, the ground seat or chair. Probably alterations of earr (for thalmhainn see Bunium flexuosum).

"Cathair thalmhainn's carbhin chroc-cheannach."-M'INTYRE'.

The yarrow and the horny-headed caraway.

Solidago virgaurea-Golden rod. Gaelic: fuinseag coille? A name given by Shaw to the herb called "Virgo pastoris." Also one of the names of the mountain-ash (Pyrus aucuparia, which see).

Jasione montana-Sheep-bit. Gaelic: dubhan nan caora (O'Reilly). Dubhan, a kidney; caora, sheep.

\section{Campanulacee.}

Campanula_Gaelic : barr-chiigeannach, bell-flowered.

"Barr-cluigeannach-sinnteach gorm-bhileach." Bell-flowered extended, blue-petalled.

C. rotundifolia-Round-leaved bell-flower. Gaelic: bròg na cubhaig, the cuckoo's shoe. Am pluran cluigeannach, the belllike flower. Welsh : bysedd ellyilon, imp's fingers. Scotch : witch's thimbles.

Lobelia dortmanna-Water-lobelia. Pliir an lochain, the lakeflower.

\section{ERICACE※.}

Erica tetralix-Cross-leaved heath. Gaelic : fraoch frangach, French heath. Fraoch an ruinnse, rinsing heath; a bunch of its stems tied together makes an excellent scouring.brush, the other kinds being too coarse. (Fraoch, anciently frach.) Welsh:

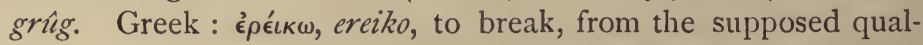
ity of some of the species in breaking the stone (medicinally). The primary meaning seems to be to burst, to break, and appears to be cognate with the Latin, fractum. Fraoch also means 
wrath, fury, hunger. "Laoch bu gharg fraoch" (Ull.), a hero of the fiercest wrath. "Fraoch!" fury, the war-cry of the M'Donalds.

E. vagans-Cornish heath. Celtic: gooneleg (Dr Hooker), the bee's resort.

E. cinerea-Smooth-leaved heath. Gaelic : fraoch bhadain, the tufted heath.

"Barr an fhraoch bhadanaich."-OLD SONG.

The top of the tufted heath.

"Gur badanach caoineil mileanta

Cruinn mopach, min cruth, mongoineach

Literally-

Fraoch groganach, dù dlıonn gris dearg." -M“INTYRE.

That heath so tufty, mellow, sweet-lipped,

Round, moppy, delicate, ruddy,

Stumpy, brown, and purple.

Fraoch an dearrasain, the heath that makes a rustling or buzzing sound.

The badge of Clan M'Donald.

Calluna vulgaris-Ling heather. Gaelic: fraoch. Heath or heather is still applied to many important domestic purposes, thatching houses, \&c., and "the hardy Highlanders frequently make their beds with it - the roots down and the tops upwards -and formerly tanned leather, dyed yarn, and even made a kind of ale from its tender tops." Langa (M'Kenzie), ling.

Arbutus uva-ursi-Red bearberry. Gaelic: grainnseag, small, grain-like. It has small red berries, which are a favourite food for moorfowl. Braoileag nan con, the dogs' berry.

A. alpina-The black bearberry. Gaelic: grainnseag dhubh, the black grain-like berry.

A. unedo - Strawberry - tree. Irish : caithne (O'Donovan). Caithim, I eat or consume.

Vaccinium myrtillus-Whortleberry. Gaelic: lus nan dearc, the berry plant (dearc, ${ }^{1}$ a berry). Gearr-dhearc, sour berry. Fraochan, that which grows among the heather. The berries are used medicinally by the Highlanders, and made into tarts and jellies, which last is mixed with whisky to give it a relish for strangers. Dearcan-fithich, the raven's berries.

V. vitis - idæa - Cowberry ; red whortleberry; cranberry.

${ }^{1}$ Originally from dearc, the eye; Sansk., darç, to see. The dark fruit resembling the pupil of the eye-hence the frequent comparisons of the eye (sisil) to this fruit (dearcag) in Grelic poetry. 
Gaelic: hus nam broighleag. Irish : braighleog (from braigh, top, summit, a mountain), the mountain-plant ; ordinary signification, a berry. Bó-dhearc, cowberry. ("Bó, a cow, from which the Greeks derived Boos, an ox"-Armstrong.) Latin: vacca and vaccinium.

"Do leacan chaoimhneil gu dearcach brioghleagach."

Thy gentle slopes abounding with whortleberries and cowberries.

Badge of Clan M'Leod.

V. oxycoccos-Cranberry. Gaelic and Irish : muileag, a word meaning a little frog; the frogberry. It flourishes best in boggy situations. Fraochag, because it grows among the heather. Monog, bog or peat berry. Mionag, the small berry.

V. uliginosum-The bogberry. Gaelic: dearc roide, the gall or bitter berry. The fruit abounds with an acid juice; when the ripe fruit is eaten, it occasions headache and giddiness.

\section{ILEACEE.}

Ilex aquifolium-Holly. Gaelic and Irish : cuileann. Welsh : celyn. A.-S. : holegn. ( $C$ in Gaelic corresponds with $h$ in the Germanic languages.) Ciil, guard, defence; ciill, that which prohibits. Compare also cuilg, gen. of colg, a prickle, or any sharp.pointed thing. The lower leaves of this tree are very prickly, and thus guard against cattle eating the young shoots. Welsh : celyn, tree, shelterer or protector; cel, conceal, shelter, cover.

"Ma theid thu ruisgte troimh thom droighinn

'S coiseachd cas-lom air preas cuileann

Cadal gun lein' air an eanntaig,

'S racadal itheadh gumn draing ort," \&c. - BLAR SHUNADAIL.

If you go naked through a thorn thicket,

And walk barefooted on the holly,

Sleep without a shirt on the nettle,

And eat horse-radish without a grin, \&c.

\section{OleaceÆ.}

Olea europæa-European olive. Gaelic and Irish : crann oladh or ola (Greek: $\epsilon \lambda a \iota a$, a word, according to Du Théis, derived from the Celtic; Welsh: olent), the oil-tree.

"Sgaoilidh e gheugan, agus bithidh a mhaise mar an crann-oladh."

"He will spread his branches, and his beauty shall be as the olive tree." Hosea xiv. 6.

Syringa vulgaris-Lilac-tree. Gaelic: craobh liath ghorm, the lilac-tree.

Ligustrum vulgare-Privet. Gaelic : ras chrann sir uine, the 
evergreen shrubbery-tree. Priobaid (M'Donald). (Latin : prizatus; Irish: priobhaid, secrecy, privacy). Its chief use is to form hedges that are required for shelter, ornament, and privacy.

Fraxinus excelsior-Ash. Gael and Irish: craobh winnseann. Irish : uinseann, uimhseann, altered into fuinse, fuinsean, fuinseog.

"Gabhaidh an t' uinnseann as an àllt

'S a chàlltuinn as a phreas."-ProverB.

The ash will kindle out of the burn,

And the hazel out of the bush.

Welsh : onen, corresponding to another Irish name, nion. Gaelic: nuin, and also oinsean. The names refer principally to the wood, and the primary idea seems to be lasting, longcontinuing, on (in Welsh), that which is in continuity. Uimh, number; seann, ancient, old ; iine, time, season. Nuin, also the letter N. Heb., nun. Fuinnseann (see Circoca), though from the same root, may have been suggested by its frequent use in the charms and enchantments so common in olden times, especially against the bites of serpents, and the influence of the "Old Serpent." Pennant, in I 772, mentions : "In many parts of the Highlands, at the birth of a child, the nurse puts the end of a green stick of ash into the fire, and while it is burning, receives into a spoon the sap or juice which oozes cut at the other end, and administers this to the new-born babe." Serpents were supposed to have a special horror of its leaves.

"Theid an nathair troimh an teine dhearg

Mu'n teid i troimh dhuilleach an ùinnsinn."

The serpent will go through fire, rather than through the leaves of the ash.

The same superstition was equally common in other countries, and the name "ash," which is said to be from the Celtic word asc, a pike, is more likely to be from the word asc, a snake, an adder. ${ }^{1}$ German : die esche.

The badge of Clan Menzies.

\section{Gentianaceæ.}

Gentiana campestris-Field gentian. Gaelic: lus a chribain, the crouching plant, or the plant good for the disease called cribain, "which attacks cows, and is supposed to be produced

1 In Scandinavian mythology the first man was called $A s k$, and the first woman Ambla - ash and elm. The court of the gods is represented in the Edda as held under an ash-Yggdrasil. Connected with these circumstances probably arose the superstitions. - ChAMBERs's ENCYCLOPÆDIA. 
by hard grass, scanty pasture, or other causes. The cows become lean and weak, with their hind-legs contracted towards the forefeet, as if pulled by a rope" (Armstrong). This plant, in common with others of this genus, acts as an excellent tonic; its qualities were well known in olden times. Welsh : cruoynllys, bent-weed; cryn, bend, curve. Gaelic : creamh, is given also as a name for gentian.

$$
\begin{aligned}
& \text { " 'N creamh na charaichean, } \\
& \text { Am bac nan staidhrachean." }-\mathrm{M} \text { 'INTYRE. }
\end{aligned}
$$

Which Dr Armstrong translates, "gentian in beds or plots." The name creamh also applies to the leek. Creamh, hart's-tongue fern, garlic, and elecampane. Welsh: craf, garlic.

Erythræa, from $\epsilon \rho v \theta \rho o s$, erythros, red flowers.

E. centaurium-Centuary; red gentian. Irish : ceadharlach (O'Reilly), the centaur. It is said that with this plant Chiron cured the wound caused by the arrows of Hercules in the Centaur's foot. Gaelic, according to Armstrong: celd bhileach, meaning hundred-leaved, a corruption of the Irish name (Cend, Irish : ceadh; Latin : centum, a hundred), - the origin of the name being probably misunderstood.

E. littoralis-Dwarf-tufted centuary. Gaelic and Irish : dreimire muire, the sea-side scrambler. Dreim, climb, clamber, scramble: muire; Latin : mare; German : meer, the sea.

Chlora perfoliata-Yellow-wort. Gaelic and Irish : dreimire buidhe, the yellow scrambler. Not in the Highlands, but found in Ireland, whence the name.

Menyanthes trifoliata-Bog-bean, buck-bean, marsh trefoil. Gaelic and Irish : poncair chapull, the mare's bean. (See Faba.) Pacharan chapull, the mare's packs or wallets, from pac, a pack, a wallet, a bundle. Tri-bhileach, the three-leaved plant. Millsean monaidh, the sweet plant of the hill.

"Millseineach, biolaireach sobhrảch."-M'LACHuin.

Abounding in bog-beans, cresses, primroses.

"The Highlanders esteem an infusion or tea of the leaves as good to strengthen a weak stomach" (Stuart).

\section{Convolvulaceæ.}

Convolvulus arvensis-Field bindweed. Gaelic: indh lus, the plant that surrounds. (See Hedera helix.)

C. sepium-Great bindweed. Gaelic and Irish : diiil mhial (Shaw), from diil, catch with a loop; and mial, a louse,-realiy signifying the plant that creeps and holds by twining. 
Cuscuta epilinum-Flax dodder. Irish : clamhainin lin, the flax kites. It is parasitical on flax, to the crops of which it is sometimes very destructive. Cunach or (Gaelic) conach, that which covers, as a shirt, a disease. A general name applicable to all the species. Welsh : llindag, the flax choker.

\section{SOLANACEe.}

Solanum dulcamara-Bitter-sweet ; woody nightshade. Gaelic and Irish : searbhag mhilis, bitter-sweet (Highland Society's Dictionary). Fuath gorm, the blue demon (fuath, hate, aversion, a demon). Miotag bhuidhe. Irish: miathog buidhe, the yellow nipper, pincher, or biter. Slat ghorm (slat, a wand, a switch ; gorm, blue).

S. tuberosum-Potato. Gaelic: bun-tata, adaptation of the Spanish batata. Sir John M'Gregor has ingeniously rendered the word bun-taghta, a choice root!

Atropa belladona - Deadly nightshade; dwale banewort. Gaelic and Irish : lus na l'oidhche, the nightweed, on account of its large black berries and its somniferous qualities. Buchanan relates the destruction of the army of Sweno, the Dane, when he invaded Scotland, by the berries of this plant, which were mixed with the drink with which, by their truce, they were to supply the Danes, which so intoxicated them that the Scots killed the greater part of the Danish army while they were asleep. IVelsh : $y$ gysiadur, the putter to sleep.

Hyoscyamus niger - Henbane. Gaelic and Irish: gafann (gabhann), the dangerous one. Detheogha, deodha, deo, breath, that which is destructive to life. Caoch-nan-cearc, that which blinds the hens. Its seeds are exceedingly obnoxious to poultry, hence the English name henbane. The whole plant is a dangerous narcotic. Welsh: slezeyg yr iâr, preventing or curing faintness.

\section{SCROPHUlaRiaCE.}

Verbascum thapsus-Mullein; hag's taper; cow's lungwort. Gaelic and Irish : cuineal Mhuire, or cuingeal Mhuire(from cuing, asthma, or shortness of breath. In pulmonary diseases of cattle it is found to be of great use, hence the name, cow's lungwort, or cuinge, narrowness, straightness, from its high, tapering stem; Mhuire, Mary's).

Veronica beccabunga-Brooklime. Gaelic: lochal, from loch, a lake, a pool, the pool-weed or lake-weed, being a water-plant. Lothal (lo, water). Irish: biolar mhiin, the contemptible cress; mùn, urine. Welsh: llychlys $y$ du'fr, squatter in the water. 
V. officinale-Common speedwell. Gaelic and Irish : lus cré, the dust-weed. Seamar chre (see Oxalis).

V. anagallis-IVater-speedwell. Irish : fualachtar, fual, water, the one that grows in the water.

Euphrasia officinalis-Eyebright. Gaelic: lus nan leac, the hillside plant; leac, a declivity. Soillseachd nan siill, soillse na sill (M'Donald), that which brightens the eye. Rein an ruisg (Stuart), water for the eye. Glan ruis, the eye-cleaner. Lightfoot mentions that the Highlanders of Scotland make an infusion of it in milk, and anoint the patient's eyes with a feather dipped in it, as a cure for sore eyes. Irish: radharcain (radhairc), sense of sight. Lin radharc (lin, the eye, wet), the eye wetter or washer. Racimin-radhairc(reim, power, authority), that which has power over the sight. Roisnin, rosg, the eye, eyesight. Caoimin (caoimh), clean. Welsh : gloywlys, the bright plant. 'Llysieuyn eufras, the herb Euphrasia (from $\epsilon \nu \phi \rho a \iota v \omega$, cuphraino, to delight, from the supposition of the plant curing blindness). Arnoldus de Villa saith, "It has restored sight to them that have been blind a long time before; and if it were but as much used as it is neglected, it would half spoil the spectacle trade" (Culpepper).

Pedicularis sylvatica-Dwarf red rattle. Irish : lusan grolla.

P. palustris-Louse-wort; red rattle. Gaelic : lus riabhach, the brindled plant, possibly a contraction of riablhdheargach (Irish), red-streaked, a name which well describes the appearance of the plant. Modhalan dearg, the red modest one. Lus na mial, louse-wort, from the supposition that sheep that feed upon it become covered with vermin. Bainne ghabhar, goat's milk, from the idea that when goats feed on it they yield more milk. Its beautiful pink flowers were used as a cosmetic.

"Sail-chuach 's bainne ghabhar, . Suadh ri t' aghaidh,

'S cha n' neil mac righ air an domhain, Nach bi air do dheidh."

Rub thy face with violet and goat's milk, And there is no prince in the world

Who will not follow thee.

Rhinanthus crista-galli-The yellow rattle. Gaelic: modhalan bhuidhe, the yellow modest one. Bodach na claiginn. Irish : bodan na cloigin, the old man with the skulls. Claigeann or (Irish) cloigoin, a skull, from the skull-like appearance of its inflated calyces.

Scrophularia nodosa-Figwort. Gaelic: lus nan cnapan, the 
knobbed plant, from its knobbed roots. Old English: kernelwort. Donn-lus, brown-wort, from the brown tinge of the leaves. Farach dubh (faracha, Irish), a beetle or mallet; dubh, dark. Wasps and beetles resort greatly to its small mallet-like flowers. Irish : fotrum ( fot, fothach), glandered-from the resemblance of its roots to tumours. In conseruence of this resemblance it was esteemed a remedy for all scrofulous diseases; hence the generic name Scrophularia.

Digitalis purpurea-Foxglove. Gaelic: lus-nam-ban-sith, the fairy women's plant. Meuran sith (Stuart), the fairy thimble. Irish: an siothan (sioth, Gaelic: sith) means peace. Sithich, a fairy, the most active sprite in Highland and Irish mythology. Meuran ${ }^{1}$ nan daoine marbh, dead men's thimbles. Meuran nan caillich mharbha, dead women's thimbles. In Skye it is called ciochan nan cailleachan marblia (Nicolson), the dead old women's paps. Irish: sian sleibhe. (Sian, a charm or spell, a wise one, a fox ; sleibhe, a hill). Welsh : menyg ellyllon, fairy's glove. O'Reilly gives another Irish name, bolgan beic (diminutive of bolg, a sack, a bag. Greek, Boגyos, bcic, bobbing, curtseying). And frequently in the Highlands the plant is known by the familiar name, an lus morr, the big plant. Lus a bhalgair (Aberfeldy), the fox-weed.

\section{OROBANCHACEÆ.}

(From Greek, opoßos, orobos, a vetch, and $a \gamma \chi \epsilon \iota v$, to strangle, in allusion to the effect of these parasites in smothering and destroying the plants on which they grow.) 'The name michog (from mich smother, extinguish, suffocate) is applied to all the species.

0. major and minor-Broom-rape. Irish and Gaelic : siorralach, (Shaw) - sior, vetches, being frequently parasitical on leguminous plants; or siorrachd, rape.

\section{VERBENACEÆ.}

Verbena officinalis-Vervain. Gaelic and Irish : trombliod,trom, a corruption of $d r u m$, from Sanscrit $d r u$, wood; hence Latin, drus, an oak, and bod or boid, a vow. Welsh : dderwen fendigaid, literally, blessed oak, - the "lherba sacra" of the ancients. Vervain was employed in the religious ceremonies of the Druids. Vows were made and treaties were ratified by its means. "Afterwards all sacred evergreens, and aromatic herbs, such as holly,

1 Meuran and digitalis (digitabulum), a thimble, in allusion to the form of the flower. 
rosemary, \&c., used to adorn the altars, were included under the term verbena" (Brockie). This will account for the name trombhod being given by O'Reilly as "vervain mallow ;" M'Kenzie, "ladies' mantle;" and Armstrong, "vervain."

\section{I_ABIATA.}

(From Latin, labium, a lip, plants with lipped corollæ.) Gaelic: lusan lipeach, or bileach.

Mentha-(From Greek M $\iota \theta \eta$, minthe. A nymph of that name who was changed into mint by Prosperine, in a fit of jealousy, from whom the Gaelic name mionnt has been derived.) Welsh: inyntys.

Mentha sylvestris-Horse-mint. Gaelic: mionnt each, horsemint; mionnt facthain, wild mint; and if growing in woods, mionnt choille, wood-mint.

M. arvensis-Corn-mint. Gaelic: mionnt an arbhair, cornmint.

M. aquatica - IVater - mint. Gaelic : cairteal. Irish : cartal, cartloin, probably meaning the water-purifier, from the verb cartam, to cleanse, and loin, a rivulet, or lon, a marsh or swampy ground. Misimean dearg (Armstrong), the rough red mint. The whole plant has a reddish appearance when young.

M. viridis - Garden-mint, spear-mint. Gaelic : mionnt ghìraidh, the same meaning; and meanntas, another form of the same name, but not commonly used.

"Oir a ta sibh a toirt an deachaimh as a mhionnt."-STUART.

For ye take tithe of mint.

M. pulegium - Pennyroyal. Gaelic: peighinn rioghail, the same meaning.

"Am bearnan bride 's a pheighinn-rioghail." - M'INTYRE.

The dandelion and the pennyroyal.

Welsh : coluddlys, herb good for the bowels. Dail y gwaed, blood leaf.

Calamintha-Basil-thyme, calamint. Gaelic : calameilt (from Greek, $\kappa a \lambda o s$, beautiful ; and $\mu \nu v \theta \eta$, minthe, mint), beautiful mint. Welsh : Llysie y gâth, cat-wort.

Rosmarinus officinalis - Common rosemary. Gaelic: ròs Mhuire. Irish : ros-mar - nar-ros, sea-dew, corruptions from the Latin (ros, dew, and marinus), the sea-dew. Ros Mhairi, Mary's rose, or rosemary. Welsh : ròs Mair. Among Celtic tribes rosemary was the symbol of fidelity with lovers. It was frequently 
worn at weddings. In Wales it is still distributed among friends at funerals, who throw the sprigs into the grave over the coffin.

Lavendula spica - Common lavender. Gaelic: lus-na-tuiise, the incense plant, on account of its fragrant odour. An lus liath, the grey weed. Lothail, " wisge an lothail," lavender-water.

Satureia hortensis-Garden savory. Gaelic: garbhag ghàraidh, the coarse or rough garden plant, from garbh, rough, \&c.

Salvia verbenacea-Clary. The Gaelic and Irish name, torman, applies to the genus as well as to this plant; it simply means "the shrubby one" (tor, a bush or shrub). The genus consists of herbs or undershrubs, which have generally a rugose appearance. A mucilage was produced from the seeds of this plant, which, applied to the eye, had the reputation of clearing it of dust; hence the English name, "clear-eye," clary (Gaelic: clearc, bright).

S. officinalis-Garden-sage (of which there are many varieties). Gaelic: athair liati, the grey father. Sàisde (from sage). Slàn lus, the healing plant, corresponding with salvia (Latin: salvere, to save). It was formerly of great repute in medicine. Armstrong remarks: "Bha barail ro mhòr aig na sean Eadalltich do 'n lus so, mar a chithear o'n rann a leanas,-

"Cur moriatur homo cui salvia crescit in horto?"

$C^{\prime}$ arson a gheibheadh duine bàs,

Aig am bheil sàisde fàs na gharaidh?

Why should the man die who has sage growing in his garden?

Teucrium scorodonia - Wood-sage. Gaelic: saisde coille, wood-sage. Sàisde fiadhain, wild sage. O'Reilly gives the name ebeirsluaigh, perhaps from obar, shall be refused, and sluagh, people, multitude, because it did not possess the virtues attributed to the other species, and even cattle refuse to eat it.

Thymus serpyllum-Thyme, wild thyme. Gaelic and Irish : lus mhic righ Bhreatainn, the plant belonging to the king of Britain's son. Lus an righ, the king's plant. This plant had the reputation of giving courage and strength through its smell; hence the English thyme (from Greek: $\theta v \mu$ os, thymos, courage, strength,- virtues which were essential to kings and princes in olden times). Highlanders take an infusion of it to prevent disagreeable dreams. Welsh : teim.

Origanum $\left\{\begin{array}{l}\text { marjorana } \\ \text { vulgare }\end{array}\right\}$-Marjoram. Gaelic and Irish : oragan, the delight of the mountain. Greek : opos, oros. Gaelic : ord, a mountain; and Greek, yavos, ganos, joy. Gaelic : gain, clapping 
of hands. Lus mharsalaidh, the merchant's weed, may only be a corrupted form of marjoram, from an Arabic word (maryamych). Seathbhog, the skin or hide softener (seathadh, a skin, a hide, and $b \circ g$, soft). " The dried leaves are used in fomentations, the essential oil is so acrid that it may be considered as a caustic, and was formerly used as such by farriers" (Don). Welsh : $y$ benrudd, ruddy-headed.

0. dictamnus-Dittany. The Gaelic and Irish name, lus a phiobaire-given in the dictionaries for "dittany"-is simply a corruption of lus a pheubair, the pepperwort, and was in all probability applied to varieties of Lepidium as well as to Origanum dictamni creti, whose fabulous qualities are described in Virgil's I 2 th ' Aneid,' and in Cicero's 'De Natura Deorum.'

Hyssopus officinalis-Common hyssop. Gaelic: isop. French: hysope. German : isop. Italian : isopo (from the Hebrew name, בז:., ezob, or Arabian, c:zzof).

"Glan mi le $h$ ' isop, agus bithidh me glan."

Purge me with hyssop, and I shall be clean.

Ajuga reptans-Bugle. Gaelic: meacan dubh fiadhain (Armstrong), the dusky wild plant. Welsh : glesyn y coed, wood-blue.

Nepeta glechoma - Ground-ivy. Gaelic: iadh shlat thalmhainn, the ground-ivy. (See Hedera helix, and Bunium flexuosum). Nathair lus, the serpent-weed,-it being supposed to be efficacious against the bites of serpents; hence the generic name, Nepeta, from nepa, a scorpion. Irish: aignean thalmhuin (aigne, affection, thalmhuin, the ground); eidhnean thalmhuin (see Hedera helix).

Ballota niger-Stinking horehound. Irish and Gaelic : gràfan or grabhan dubh, the dark opposer (grab, to hinder or obstruct). It was a favourite medicine for obstructions of the viscera: or it may refer to grab, a notch, from its indented leaves.

Lycopus europæus-Water-horehound. Irish : feoran curraidh, the green marsh-plant (currach, a marsh).

Marrubium vulgare-White horehound. Gaelic and Irish : gràfan or gräbhan bàn, the white indented, \&c. (See Ballota niger).

Lamium album - White dead-nettle; archangel. Gaelic: teanga mhin, the smooth tongue. Ionntag bhan, white nettle. Ionntag mhàrbh, dead nettle. (For Ionntàg see Urtica.)

L. purpureum - The red dead-nettle. Gaelic: ionntag dhearg, red nettle. 
Galeopsis tetrahit-Common hemp-nettle. Gaelic: an gath $d u b h$, the dark bristly plant ( $g a t h$, a sting, a dart). It becomes black when dry, and has black seeds.

G. versicolor-Large-flowered hemp-nettle. Gaelic: an gath buidhe, - an gath mor, the yellow bristly plant-the large bristly plant. Very abundant in the Highlands, and troublesome to the reapers at harvest-time, from its bristly character. It is called yellow on account of its large yellow flower, with a purple spot on the lower lip.

Stachys betonica-Wood-betony. Gaelic: lus bheathag, the life-plant, nourishing plant (from Irish : beatha; Greek: $\beta \iota \omega \tau \alpha$; Latin : vita,-life, food). "Betonic, a Celtic word; ben, head, and ton, good, or tonic" (Sir W. J. Hooker). Biatas (from biadh, feed, nourish, maintain). "A precious herb, comfortable both in meat and medicine" (Culpepper). Glasair coille, the wood green one. The green leaves were used as a salad: any kind of salad was called glasag.

S. sylvatica-Wound-wort. Gaelic: lus nan scorr, the woundwort (scorr, a cut made by a knife or any sharp instrument). Irish : caubsadan.

Prunella vulgaris-Self-heal. Gaelic and Irish : dubhan ceann chosach, also dubhanuith. These names had probably reference to its effects as a healing plant. "It removes all obstructions of the liver, spleen, and kidneys" (dubhan, a kidney, darkness; ceann, head, and cosach, spongy or porous). Slàn lus, healing plant. Lus a chridh, the heart-weed. Irish : ceanabhan-beg, the little fond dame; cean, fond, elegant, and ban, woman, wife, dame.

\section{BORAGINACEÆ.}

Borago officinalis-Borage. Gaelic and Irish : borrach, borraist, borraigh, all these forms are evidently derived from borago, altered from the Latin, cor, the heart, and ago, to act or effect. The plant was supposed to give courage, and to strengthen the action of the heart; "it was one of the four great cordials." Borr in Gaelic means to bully or swagger ; and borrach, a haughty man, a man of courage. Welsh: llawenllys (llawen, merry, joyful), the joyful or glad plant.

Lycopsis arvensis-Bugloss. Gaelic: lus-teang' an daimh, ox-tongue. Boglus, corruption of bolg, an ox; lus, a plant. Welsh: tafod yr ych, the same meaning. Bugloss, fron 1 Greek $\beta$ ovs, bous, an ox, and $\gamma \lambda \omega \sigma \sigma \alpha$, gloss $a$, a tongue, in reference to the roughness and shape of the leaves. 
Myosotis palustris-Marsh scorpion-grass or forget-me-not. Gaelic and Irish : cotharach, the protector (cothadh, protection); perhaps the form of the racemes of flowers, which, when young, bend over the plant as if protecting it. Lus nam mial, the louseplant,-probably a corruption from miagh, esteem. Lus midhe (O'Reilly), a sentimental plant that has always been held in high esteem.

Symphytum officinale-Comfrey. Gaelic: meacan dubh, the large or dark plant. Irish: lus na conamh briste, the plant for broken bones. The root of comfrey abounds in mucilage, and was considered an excellent remedy for uniting broken bones. "Yea, it is said to be so powerful to consolidate and knit together, that if they be boiled with dissevered pieces of flesh in a pot, it will join them together again " (Culpepper).

Echium vulgare-Viper's bugloss. Boglus (see Lycopsis) and us na nathrach, the viper's plant.

Cynoglossum officinale - Common hound's - tongue. Gaelic and Irish : teanga con (O'Reilly). Teanga chii, dog's-tongue.

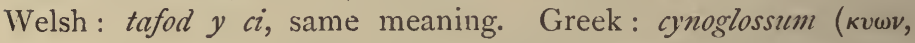
kyon, a dog, and $\gamma \lambda \omega \sigma \sigma a$, glossa, a tongue), name suggested from the form of the leaves.

\section{Pinguiculacer.}

Pinguicula vulgaris-Bog-violet. Gaelic: brog na cubhaig, the cuckoo's shoe, from its violet-like flower. Badan measgan, the butter mixer; badan, a little tuft, and measgan, a little butter-dish; or measg, to mix, to stir about. On cows' milk it acts like rennet. Lus a bhainne, the milk-wort. It is believed it gives consistence to milk by straining it through the leaves. Uachdar, surface, top, cream, - a name given because it was supposed to thicken the cream.

\section{Primulace.e.}

Primula vulgaris-Primrose. Gaelic: sobhrach, sobhrag.

"A shobhrach, geal-bhui nam bruachag,

Gur fan-gheal, snughar, do ghnùis !

Chinneas badanach, cluasach,

Maoth-mhin, baganta luaineach.

Bi'dh tu t-eideadh sa'n earrach

'S 'càch ri falach an sìl." -M'DonaLD.

Pale yellow primrose of the bank, So pure and beautiful thine appearance !

Growing in clumps, round-leaved, 
Tender, soft, clustered, waving ;

Thou wilt be dressed in the spring

When the rest are hiding in the bud.

The Irish name soghradhach (Shaw), means amiable, lovely, acceptable. The Gaelic names have the same meaning. Sobh or subh, pleasure, delight, joy. Soradh, soirigh, are contractions ; also samharcan. Irish : samharcain (samhas, delight, pleasure).

"Am bi na samhraichean s' neoinean fann."-OLD Song.

"Gu tric anns' na bhuinn sinn a t' sòrach."-Munro.

Often we gathered there the primrose.

Welsh: briollu,_briol, dignified; allneedd, key. "The queenly flower that opens the lock to let in summer" (Brockie).

P. veris-Cowslip. Gaelic: muisean, the low rascal, the devil. "A choire mhuiseanaich," a dell full of cowslips. Cattle refuse to eat it, therefore farmers dislike it. Brog na cubhaig (M'Kenzie), the cuckoo's shoe. Irish : seichearlan, seicheirghin, seicheirghlan, from seiche, hide or skin. It was formerly boiled, and " an ointment or distilled water was made from it, which addeth much to beauty, and taketh away spots and wrinkles of the skin, sun-burnings and freckles, and adds beauty exceedingly." The name means the "skin-purifier." Baine bo bhuie, the yellow cow's milk. Baine bo bleacht, the milk-cow's milk.

P. auricula-Auricula. Gaelic: lus na bann-righ, the queen's flower.

P. Polyanthus-Winter primrose. Gaelic: Sobhrach gheamhraidh.

Cyclamen hederæfolia_Sow-bread. Gaelic : culurin (perhaps from cul or cullach, a boar, and aran, bread), the boar's bread.

Lysimachia (from Greek $\lambda v \sigma \omega$ and $\mu \alpha \chi \hat{o} \mu a \iota$, I fight).

L. vulgaris-Loose-strife. Gaelic and Irish: lus na sithchaine, the herb of peace (sith, peace, rest, ease ; cáin, state of). Conaire, the keeper of friendship. The termination "aire" denotes an agent; and conall, friendship, love. An seileachan buidhe, the yellow willow herb.

L. nemorum-Wood loose-strife; yellow pimpernel. Gaelic and Irish: seamhair Mhuire (seamhair, seamh, gentle, sweet, and feur, grass; seamhrog (shamrock), generally applied to the trefoils and wood-sorrel. (See Oxalis.) Mhuire of Mary ; Maire, Mary. This form is especially applied to the Blessed Virgin Mary. In the Mid-Highlands more frequently called Samman (Stewart). Lus. Cholum-cille, the wort of St Columba, the apostle 
of Scotland. Columb, a dove; cille, of the church. This name is given in the Highlands to Hypericum, which see. Rosor (O'Reilly). Ros is sometimes used for lus. Ros-or, yellow or golden rose. "From the Sanskrit, ruksha or rusha, meaning tree, becomes in Gaelic ros, a tree or treelet, just as daksha, the right hand, becomes dexter in Latin and deas in Gaelic. Ros, therefore, means a tree or small tree, or a place where such trees grow-hence the names of places that are marshy or enclosed by rivers, as Roslin, Ross-shire, Roscommon," \&c.-CANON BOURKE.

Anagallis arvensis - Pimpernel, poor man's weather-glass. Gaelic : falcair. Irish : falcaire fodhain, the wild cleanser ( fal$c a d h$, to cleanse). The name expressing the medicinal qualities of the plant, which, by its purgative and cleansing power, removes obstructions of the liver, kidneys, \&c. Falcaire fuair, - falcaire also means a reaper, and fuair, cold; fuaradh, to cool, a weather-gauge. The reaper's weather-gauge, because it points out the decrease of temperature by its hygrometrical properties -when there is moisture the flower does not open. Loisgean (M'Donald), from loisg, to put in flame, on account of its fiery appearance. Ruinn ruise (O'Reilly). Ruinn means sex, and by pre-eminence the "male;" ruise is the genitive case of ros. It is still called the male pimpernel in some places. The distilled water or juice of this plant was much esteemed formerly for cleansing the skin.

\section{Plumbaginace}

Armeria maritima-Thrift. Gaelic: tonn a chladaich (Armstrong), the "beach-wave," frequent on the sea-shore, banks of rivers, and even on the Grampian tops. Bàr-dearg, red-top, from its pink flower. Neoinean chladaich, the beach daisy, from clàdach, shore, beach, sandy plain.

\section{PlantaginaceÆ.}

Plantago major-Greater plaintain. Gaelic and Irish : cuach Phàdraig, Patrick's bowl or cup,-in some płaces cruach Phàdraig, Patrick's heap or hill. Welsh : llydain y fford, spread on the way.

P. lanceolata-Rib-wort. Gaelic and Irish : slàn lus, the healing plant.

"Le meilbheig, le neòinean 's le slàn-lus." -M‘LEOD. With poppy, daisy, and rib-zort. 
Lus an 't' slanuchaidh (lus, a wort, a plant-herb, chiefly used for plant ; it signifies also power, force, efficacy ; slanuchaidh, a participial noun from slan; Latin, sanus), the herb of the healing, or healing power; a famous healing plant in olden times. Deideag. Irish : deideog ( $a g$ and $\partial g$, young, diminutive terminations; deid, literally deud or deid, a tuoth), applied to the row of teeth, and also to the nipple (Gaelic, diddi; English, titty), because like a tooth, hence to a plaything,-play, gerugare, bo-peep, a common word with nurses.

\footnotetext{
" 1 'iad sid an geiltre glé ghrinn.

Cinn deideagan measg feoir," \&c.-M'Donald.

Scenes of startling beauty,

Plantain-heads among the grass, \&c.
}

Armstrong translates it "gewgaws" amongst the grass; but the editor of 'Sar-obair nam Bard Gaelach'- see his vocabularygives deideagan, rib-grass, which renders the line intelligible. Bodaich dhubha, the black men,-children's name in Perthshire. Welsh : llwoynhidydl-penairr.

\section{PARONYCHIACEE.}

Herniaria glabra-Rupture-wort; burst-wort. Gaelic and Irish: lus an t' sicnich ( $\left.\mathrm{M}^{\prime} \mathrm{Kenzie}\right)$, from sic, the inner skin that is next the viscera in animals. "Bhrist an $t$ sic," the inner skin broke. "Mam-sic," rupture, hernia. Not growing naturally in Scotland, but was formerly cultivated by herbalists as a cure for hernia.

\section{Chenopodiace⿸.}

Amaranthus caudatus - Love-lies-bleeding. Gaelic: lus a ghràidh, the love plant. Gràdh, love.

Spinacia oleracea - Spinage. Gaelic : bloinigean gàraidh. Blonag, fat (Welsh, bloneg; Irish, blanag); gàradh, a garden. Slàp chàil (M'Alpin); slàp, to flap; càl, cabbage. Welsh : yspisoglys.

Beta maritima-Beet, mangel-wurzel. Gaelic: betis, biotas. Irish : biatas. Welsh : beatzes (evidently on account of its feeding or life-giving qualities). Greek: Bíos. Latin: vita, life, food; and the Gaelic: biadh, feed, nourish, fatten. Cornish: boet.

Suæda maritima-Sea-side goose grass. $\}$ Gaelic and Irish : Salicornia herbacea-Glass-wort. $\quad$ praiseach na màra, the sea pot-herb. Name applied to both plants. For praiseach, see Crambe maritima. 
Atriplex hastata and patula-Common orache. Gaelic and Irish : praiseach mhin. Min, meal, ground fine, small. Still used by poor people as a pot-herb. Ceathramha-luain-griollog (O'Reilly), loin-quarters. Ceathramadh caorach (Bourke), sheep's quarters. The name griollog is applied also to the samphire.

A. portulacoides - Purslane-like orache. Gaelic and Irish: purpaidh, purple. A name also given to the poppy. Name given on account of the purple appearance of the plant, it being streaked with red in the autumn.

Chenopodium vulvaria (or olidum) - Stinking goosefoot. Irish : elefleog. El or ela, a swan; and flè or flèdh, a feast. It was said to be the favourite food of swans. Scotch: olour (Latin, olor, a swan).

C. album - White goosefoot. Gaelic and Irish: praiseach fiadhain, wild pot-herb. The people of the Western Highlands, and poor people in Ireland, still eat it as greens. Praiseach glàs, green pot-herb, a name given to the fig-leaved goosefoot (ficifolium).

C. Bonus-Henricus-Good King Henry, wild spinage, English Mercury. Gaelic and Irish : praiseach bratthair, the friar's potherb. (Bràthair means brother, also friar-frìre). Its leaves are still used as spinage or spinach, in defect of better.

\section{LAURACE正.}

Laurus (from Sanskrit labhasa, abundance of foliage; root $l a b h$, to take, to desire, to possess-akin to Greek, $\lambda \alpha \mu \beta a v \omega$, lambano).-Gaelic : lamh, a hand (Canon Bourke).

L. nobilis - The laurel, the bay-tree (which must not be confounded with our common garden laurel, Prunus lauro-cerasus and P. lusitanicus). Gaelic and Irish : labhras. Crann laoibhreil, the tree possessing richness of foliage. With its leaves poets and victorious generals were decorated. The symbol of triumph and victory. It became also the symbol of massacre and slaughter, hence another Gaelic name, casgair, to slaughter, to hit right and left. Ur uaine, the green bay-tree.

"Agus e' ga sgaoileadh fèin a mach mar ür chraoibh uaine."

And spreading himself like a green bay-tree.-PSALM xxxvii. 35 .

$U r=$ bay or palm tree, from the Sanskrit, ïrh, to grow up. Palm Sunday is styled "Doinhnach an iuir," the Lord's day of the palm.

L. cinnamomum-Cinnamon. Gaelic and Irish : caineal. 
" 'Se 's millse na 'n caineal."-BeINN-Dorain.

It is sweeter than cinnamon.

Canal (Welsh : canel).

"Rinn mi mo leabadh cùbhraidh le mirr, aloe, agus canal."-Proveris vii. 17.

I have perfumed my bed with myrrh, aloes, and cinnamon.

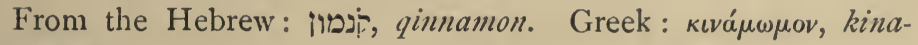
monmon.

\section{Polygonaceæ.}

Polygonum (from $\pi 0 \lambda v s$, many, and yovv, knee, many knees or joints).-Gaelic: lusan gluineach, kneed or jointed plants.

Polygonum bistorta-Bistort, snakeweed. Gaelic and Irish: bilur (O'Reilly). Seems to mean the same as biolair, a watercress. The young shoots were formerly eaten. Welsh: lysiau'r neidr, adder's plant.

P. amphibium-Amphibious persicaria. Gaelic and Irish: gluineach an wisge, the water-kneed plant. It is often floating in water. Ghineach dhearg, the red-kneed plant. Its spikes of flowers are rose-coloured and handsome. Armstrong gives this name to $P$. convolzulus; which is evidently wrong.

P. aviculare-Knot-grass. Gaelic and Irish : ghineach bheag (O'Reilly), the small-jointed plant.

P. convolvulus - Climbing persicaria; black bindweed; climbing buckwheat. Gaelic and Irish: gluineach dhubh, the dark-jointed plant.

P. persicaria-The spotted persicaria. Gaelic and Irish: gluineach mhor, the large-jointed plant. Am boinne-fola (Fergusson), the blood-spot. Lus chrann ceusaidh (M'Lellan), herb of the tree (of) crucifixion. The legend being that this plant grew at the foot of the Cross, and drops of blood fell on the leaves, and so they are to this day spotted.

P. hydropiper - Water - pepper. Gaelic: lus an fhògair (M'Kenzie), the plant that drives, expels, or banishes. It had the reputation of driving away pain, flies, \&c. "If a good handful of the hot biting arssmart be put under the horse's saddle, it will make him travel the better though he were half tired before "-Culpepper. Gluineach tèth, the hot-kneed plant.

\section{Rumex obtusifolius}

$"$ crispus " conglomeratus

\} -Dock. Gaelic and Irish : copagcopagach, copach, bossy. Welsh : copa, tuft, a top. 
R: sanguineus-Bloody-veined dock. Gaelic: a chopagach dhèrg, the red dock. The stem and veins of leaves are bloodred.

R. alpinus-Monk's rhubarb. Gaelic: lus na purgaid, the purgative weed. A naturalised plant. The roots were formerly used medicinally, and the leaves as a pot-herb. Welsh : arianllys. The same name is given for rue.

R. acetosa-Common sorrel. Gaelic: samh, sorrel. Irish : samhadh bo, cow-sorrel (for samh see Oxalis). Puinneag (M'Donald). Irish : puineoga. Name given possibly for its efficacy in healing sores and bruises (a pugilist, puinneanach). Sealbhag, not from sealbh, possession, more likely from searbh, sour, bitter, from its acid taste.

\footnotetext{
"Do shealbhag ghlàn 's do luachair A bòrcadh suas ma d' choir."-M'DoNALD.

Thy pure sorrel and thy rushes Springing up beside thee.
}

Sealgag (Irish, sealgan), are other forms of the same name. Copog shraide, the roadside or lane dock. Sobh (Shaw), the herb sorrel.

R. acetosella-Sheep's sorrel. Gaelic and Irish : ruanaidh, the reddish-coloured. It is often bright red in autumn. Pluirin seangan (O'Reilly), the small-flowered plant (pluran, a small flower; seangan, slender). Samhadh caora (O'Reilly), sheep's sorrel.

Oxyria reniformis - Mountain-sorrel. Gaelic and Irish: sealbhaig nan fiadh, the deer's sorrel.

\section{ARistolochiacex.}

Aristolochia clematitis-Birth-wort. Culurin (see Cyclamen). Asarum europæum - Common asarum. Gaelic : asair (M'Donald), from the generic name, said to be derived from Greek- $a$, privative, and $\sigma \epsilon \iota \rho$, bandage. The leaves are emetic, cathartic, and diuretic. The plant was formerly employed to correct the effects of excessive drinking, hence the French, cabaret.

\section{EMPETRACE⿸⿻}

Empetrum nigrum-Crow-berry. Gaelic and Irish : lus nut fionnag (fionnag, a crow). Sometimes written fiannag, fiadhag (dearc fithich, raven's berry ; caor fionnaig, crow-berry), the ber- 
ries which the Highland children are very fond of eating, though rather bitter. Taken in large quantities, they cause headache. Grouse are fond of them. Boiled with alum they are used to produce a dark-purple dye. Lus na stalog (O'Reilly), the starling's plant.

\section{EUPHORBIACEÆ.}

\section{$\left.\begin{array}{c}\text { Euphorbia exigua } \\ , \quad \text { helioscopia }\end{array}\right\}$-Spurge. Gaelic and Irish : spuirse = spurge. Foinneamh hus, wart-wort.}

E. peplus-Petty spurge. Gaelic and Irish : lus leusaidh, healing plant. The plants of this genus possess powerful cathartic and emetic properties. E. helioscopia has a particularly acrid juice, which is often applied for destroying warts, hence it is called foinneamh lus. Irish : gear neimh (gear or geur, severe, and neimh, poison, the milky juice being poisonous.)

E. paralias-Sea-spurge. Irish : buidhe na ningean (O'Reilly), the yellow plant of the waves (nin, a wave), its habitat being maritime sands. Not found in Scotland, but in Ireland, on the coast as far north as Dublin. This and the preceding species are extensively used by the peasantry of Kerry for poisoning, or rather stupefying, fish.

Buxus sempervirens - Box, Gaelic and Irish: bocsa, an alteration of $\beta v \xi o s$, the Greek name.

"Suidhichidh mi anns an fhàsach an giuthas, an gall ghiúthas, agus am bocsa le cheile."-IsAiah.

I will set in the desert the fir-tree and the pine and the box together.

The badge of Clan M'Pherson and Clan M'Intosh.

Mercurialis perennis-Wood mercury. Gaelic: lus ghlinnebhracadail. Lus ghlinne, the cleansing wort ; bracadh, suppuration, corruption, \&c. It was formerly much used for the cure of wounds.

\section{Cucurbitace..}

Cucumis sativus-Cucumber. Gaelic and Irish : cularan, perhaps from culair, the palate, or culear, a bag.

"Is cuimhne leinne an t-iasg a dh 'ith sinn san Ephit gu saor; na-cularain agus na mealbhucain." -NuMBERS xi. 5 .

We remember the fish that we did eat in Egypt freely, and the cucumber and the melons.

"'Sa thorc nimhe ri sgath a chularan." - M'DonaLD.

The wild boar destroying his cucumbers. 
Irish : cucumhar (O'Reilly), cucumber, said to be derived from the Celtic word cuc (Gaelic, cuach), a hollow thing. In some species the rind becomes hard when dried, and is used as a cup. Latin: cucurbita, a derivative from the Celtic. (See Loudon.) Welsh : chroerwe ddreff $=$ water-sour.

Cucumis melo-Melon. Gaelic and Irish: meal-bhuc, from mel or mal (Greek, $\mu \in \lambda o v$, an apple), and buc, size, bulk. According to Brockie, "mealbhucain (plural), round fruit covered with warts or pimples." Mileog, a small melon.

\section{URTICACEE.}

Urtica-A word formed from Latin : uro, to burn.

$\left.\begin{array}{l}\text { U. urens } \\ \text { dioica }\end{array}\right\}$-Nettle (Anglo-Saxon, nedl, a needle). Gaelic and Irish: feanntag, neandog, ${ }^{1}$ deanntag, iontag, iuntag (from feannta, flayed, pierced, pinched-feann, to flay, on account of its blistering effects on the skin; ang, a sting; iongna, nails). Latin : ungues.

\section{"Sealbhaichidh an t' ionntagach."-HosEA. \\ The nettles shall possess them.}

To this day it is boiled in the Highlands and in Ireland by the country people in the spring-time. Till tea became the fashion, nettles were boiled in meal, and made capital food. Caol-fail-caol, slender; fàl, spite, malice. In the Hebrides often called sradag (a spark), from the sensation (like that from a fiery spark) consequent upon touching. (Stuart.)

Cannabis sativa-Hemp. Gaelic and Irish: caineab, the same as cannabis, and said to be originally derived from Celtic, can, white; but the plant has been known to the Arabs from time immemorial under the name of quaneb. Corcach, hemp.

\footnotetext{
"Buill do' n chaol chdrcaidh."-M 'DONALD.

Tackling of hempen ropes.
}

Welsh : cynarch.

Parietaria officinalis - Wall pellitory. Gaelic and Irish : lus a bhallaillh, from balladh (Latin, vallum; Irish, balla), a wall. A weed which is frequently found on or beside old walls or rubbish heaps, hence the generic name "parietaria," from

1 "Neandog, the common name for it in Ireland. In feminine nouns, the " first consonant (letter) after the article $a n$ (the) is softened in sound. 'An feanntag' - ' $f$ ' when affected loses its sound, and ' $N$ ' is sounded instead: ' $\mathrm{N}$ (f)eantog.'"-CANON BOURKE. 
paries, a wall. Irish : mionntas chàisil (caisiol, any stone building), the wall-mint. For mionntas, see Mentia.

Humulus lupulus-Hop. Gaelic and Irish: lus an leannalionn luibh, the ale or beer plant. Lionn, leann (Welsh, Ihyn) beer, ale.

Ulmus-Elm. Celtic: ailm. The same in Anglo-Saxon, Teutonic, Gothic, and nearly all the Celtic dialects. Hebrew: הלs, elah, translated oak, terebinth, and elm.

U. campestris-Gaelic and Irish : leamhan, slamhan (Shaw), liobhan. Welsh: llweyfen. According to Pictet, in his work, 'Les Origines Indo-Europeennes ou les Aryas Primitifs,' p. $22 \mathrm{I}$, "'To the Latin: 'Ulmus' the following bear an affinity (respond)-Sax.: ellm. Scand.: almr. Old German: elm. Rus.: ilemu. Polish : ilma. Irish : ailm, uilm, and by inversion, 'leamh,' or 'leamhan." He says the root is ul, meaning to burn. The tree is called from the finality of it, "to be burned." That is his opinion, and he is probably right. The common idea of leamhan is that it is from leamh, tasteless, insipid, from the taste of its inner bark; and liobh means smooth, slippery. And the tree in Gaelic poetry is associated with or symbolic of slipperiness of character, indecision. Cicely M'Donald, who lived in the reign of Charles II., describing her husband, wrote as follows :-

"Bu tu' n t-iubhair as a choille,

$B u$ tu' $n$ darach daingean làidir,

Bu tu' $n$ cùileann, bu tu 'n droighionn,

$\mathrm{Bu}$ tu' $\mathrm{n}$ t' abhall molach, blàth-mhor,

Cha robh meur annad do' $n$ chritheann,

Cha robh do dhlighe ri feàrna,

Cha robh do chàirdeas ri leamhan,

"Bu tu leannan nam ban àluinn."

Thou wast the yew from the wood,

Thou wast the firm strong oak,

Thou wast the holly and the thorn,

Thou wast the rough, pleasant apple,

Thou had'st not a twig of the aspen,

Under no obligation to the alder,

And hadst no friendship with the elm,

Thou wast the beloved of the fair.

Ficus-Nearly the same in most of the European languages. Greek: $\sigma v \chi \eta$. Latin : ficus. Celtic: fige.

F. carica-Common fig-tree. Gaelic and Irish : crann fige or fighis. 
"Ach fòghlumaibh cosamhlach do'n chrann fhìge."

Learn a parable from the fig-tree.

Morus-Greek : $\mu$ opos, moros. Latin: morus, a mulberry. Loudon, in his 'Encyclopedia of Plants,' says it is from the Celtic mor, dark-coloured. There is no such Celtic root; it may be from the Sanskrit, murch, Scotch, mirk, darkness, obscurity; and the Greek name has also this meaning. The fruit being of a darkish red colour. Old Ger. and Danish : mur-ber.

M. nigra - Common mulberry. Gaelic and Irish : crànnmaol-dhearc, tree of the mild aspect, or if dearc here be a berry, the mild-berry tree. Maol (Latin, mollis) has many significations. Bald, applied to monks without hair, as Maol Cholum, St Columba; Maol Iosa, Maol Brighid, St Bridget, \&c. A promontory, cape, or knoll, as Maol Chinntire, Mull of Cantyre. Malvern, maol, and bearna, a gap. To soften, by making it less bitter, as "dean maol é," make it mild. Hence mulberry, mildberry (Canon Bourke).

\section{Amentifere and CUPUlifere.}

Catkin-bearers-Gaelic : caitcan, the blossom of osiers.

" 'Nis treigidh coileach á ghucag

'S caitean brucach nan craobh." - M 'Donal.1).

Now the cock will forsake the buds

And the spotted catkins of the trees.

Quercus-Said in botanical works to be from the Celtic, quer, fine. There is no such word in any Celtic dialect, and even Pictet has failed, after expending two pages on it, to explain it.

Q. robur-("Robur comes from the Celtic, ro, excelling, and bur, development"-Canon BOURKE). The oak. Gaelic and Irish : dair, genitive dàrach, sometimes written dàrag, dìr, drù. Sanskrit : dru, druma, druta, a tree, the tree; daru, a wood.

"Sàmhach' us mòr a bha 'n triath, Mar dharaig 's i liath air Lubar,

A chaill a dlu-dheug o shean Le dealan glan nan spéur, Tha 'h-aomadh thar srùth o shliabh, A còinneach mar chiabh a fuaim."-Ossian.

Silent and great was the prince

Like an oak-tree hoary on Lubar,

Stripped of its thick and aged boughs

By the keen lightning of the sky,

It bends across the stream from the hill, Its moss sounds in the wind like hair. 
Om, omna, the oak (O'Reilly). "Cormac, King of Cashel, Ireland, A.D. 903 , says of omna that it equals fuamna, sounds, or noises, because the winds resound when the branches of the oak resist its passage. According to Varro, it is from os, mouth, and men, mind, thinking - that is, telling out what one thinks is likely to come. Cicero agrees with this, 'Osmen voces hominum' "-Canon Bourke. Compare-Latin : omen, a sign, a prognostication, - it being much used in the ceremonies of the Druids. Omna, a lance, or a spear, these implements being marle from the wood of the oak. Greek: $\delta o p v$, a spear, because made of wood or oak. Eitheach, oak, from eithim, to eat, an old form of ith. Latin : ed-ere, as "oak" is derived from $a k$ (Old German) to eat (the acorn). The "oak" was called Quercus esculus by the Latins. Rail, railaidh, oak.

\section{" Ni bhiodh achd, aon dhearc ar an ralaidh."}

There used to be only one acorn on the oak.

Canon Bourke thinks it is derived from ro, exceeding, and ail, growth ; or $r i$, a king, and al or ail-that is, king of the growing plants. The Highlanders still call it righ na coille, king of the wood. The Spanish name roble seems to be cognate with robur.

Q. ilex-Holm-tree. Gaelic and Irish: craobh thuilm, genitive of tolm, a knoll, may here be only an alteration of "holm." Darach sior-uàine, ever-green oak.

Q. suber-The cork-tree. Gaelic: crànn àirceain. Irish : crann àirc. Airc, a cork.

Fagus sylvatica-Beech. Gaelic and Irish: craobh fhaibhile. Welsh : ffareydd. Fai, from $\phi a \gamma \omega$, to eat. $\phi \eta \gamma o$ s, the beech-tree. This name was first applied to the oak, and as we have no Quercus esculus, the name Fagus is applied to the beech and not to the oak. Oruin (O'Reilly), see Thuja articulata. Beith na measa, the fruiting birch. Meas, a fruit, as of oak or beech-like "mess," "munch." French : manger, to eat.

F. sylvatica var. atrorubens-Black beech. Gaelic: faibhile dubh (Fergusson), black beech, from the sombre appearance of its branches. "The "mast" of the beech was used as food, and

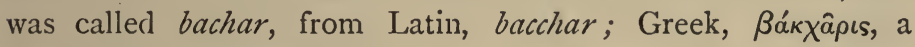
plant having a fragrant root. A name also given to Valeriana celtica (Sprengel), Celtic nard.

Carpinus-Celtic: car, wood; and pin, a head. It having been used to make the yokes of oxen. 
C. betulus-Hornbeam. Gaelic : leamhan bog, the soft elm. (See Ulmus campestris).

Corylus avellana-Hazel. Gaelic and Irish : càlltuinn, càlldainn, callduinn, cailtin, colluinn. Welsh : callen. Cornish : colwiden. Perhaps from Armoric: call. Gaelic: coill. Irish : coill, a wood, a grove. New Year's time is called in Gaelic, coill; " oidhche coille," the first night of January, then the hazel is in bloom. The first night in the new year, when the wind blows from the west, they call dair na coille, the night of the fecundation of trees ("Statistics," par. Kirkmichael). In Celtic superstition the hazel was considered unlucky, and associated with loss or damage. The words call, coll, collen, have also this signification; but if two nuts were found together (cnò chomhlaich), good luck was certain. The Bards, however, did not coincide with these ideas. By it they were inspired with poetic fancies. "They believed that there were fountains in which the principal rivers had their sources; over each fountain grew nine hazel trees, caill crinmon (crina, wise), which produced beautiful red nuts, which fell into the fountain, and floated on its surface, that the salmon of the river came up and swallowed the nuts. It was believed that the eating of the nuts caused the red spots on the salmon's belly, and whoever took and ate one of these salmon was inspired with the sublimest poetical ideas. Hence the expressions, 'the nuts of science,' 'the salmon of knowledge." " O'Curry's 'Manners and Customs of the Ancient Irish.'

The badge of Clan Colquhoun.

Alnus-Name derived from Celtic. $A l$, a growth; and lan, full. According to Pictet, it is from alka, Sanskrit for a tree.

A. glutinosa-Common alder. Gaelic and Irish : feàrnfeàrn, same origin as varâna (Sanskrit), a tree. Welsh : gwernen - gzern, a swamp. It grows best in swampy places, and beside streams and rivers. Many places have derived their names from this tree, Gleann Fearnaite. Fearnan, near Loch Tay; Fearn, Ross-shire, \&c. Ruaim (O'Reilly) (ruadh, red), it dyes red. When peeled it is white, but it turns red in a short time. The bark boiled with copperas makes a beautiful black colour. The wood has the peculiarity of splitting best from the root, hence the saying

"Gach fiodh o'n bhàrr, 's am feìrna o'n bhun."

Every wood splits best from the top, but the alder from the root.

Betula alba-Birch. Gaelic and Irish: beatha. IVelsh: 
bedlu, seemingly from beath. Greek: $\beta \iota \omega \tau \eta$. Latin : vita, life. Also the name of the letter $B$ in Celtic languages, corresponding to Hebrew Beth (meaning a house). Greek : Beta. Generally written beith.

\author{
"Sa bheith chubhraidh."-Ossian. \\ In the fragrant birch.
}

The Highlanders formerly made many economical uses of this tree. Its bark (meilleag), they burned for light, and the smooth inner bark was used, before the invention of paper, for writing upon, and the wood for various purposes.

The badge of the Clan Buchanan.

B. verrucosa-Knotty birch. Gaelic: beatha carraigeach, the rugged birch; beatha dubh-chasach, the dark-stemmed birch.

B. pendula-Gaelic: beatha dubhach, the sorrowful birch (dubhach, dark, gloomy, sorrowful, mourning, frowning). In Rannoch and Breadalbane: Beatha cluasach, the many (drooping) ear birch. (Stuart.)

B. nana.-Dwarf birch. Gaelic : beatha beag (Fergusson), the small birch.

Castanea vesca-Common chestnut. Gaelic and Irish : chraobh geanm-chno.

"No na craobha geann-chno cosmhuil r'a gheugaibh."-EzEkIEL xxxi. 8.

Nor the chestnut-tree like his branches.

Geanm or geann, natural love, pure love, such as exists between relatives, - the tree of chaste love, and cno, a nut. The Celts evidently credited this tree with the same virtues as the chaste tree, Vitex agnus castus (Greek, ảyvòs; and Latin, castus, chaste). Hence the Athenian matrons, in the sacred rites of Ceres, used to strew their couches with its leaves. Castanea is said to be derived from Castana, a town in Pontus, and that the tree is so called because of its abundance there. But the

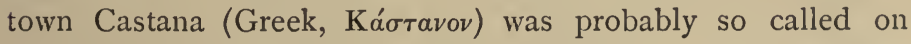
account of the virtues of its female population. If so, the English name chestnut would mean chaste-nut, as it is in the Gaelic. Welsh : castan (from Latin, caste), chastely, modestly. The chestnut-tree of Scripture is now supposed to be Platanus orien. talis, the Chenar plane-tree.

[Asculus hippocastanum - The horse-chestnut. Gaelic: geanm chno feadhaich (Fergusson). Belongs to the order Aceracea. Was introduced to Scotland in 1 709.] 
Populus alba - Poplar. Gaelic: pobhuill. Irish : poibleag. German : pappel. Welsh and Armoric: pobl. Latin : populus. This name has an Asiatic origin, and became a common name to all Europe through the Aryan family from the East. ${ }^{1}$ Pictet explains it thus: "Ce nom est sans doute une reduplication de la racine Sanskrit pul, magnum, altum." Pul pul, great, great, or big, big, as in the Hebrew construction, very big. We still say in Gaelic mor mor, big, big, for very big. Pul pul is the Persian for poplar, and pullah for salix. This tree is quite common in Persia and Asia Minor, hence it was as well known there as in Europe. The name has become associated with populus, the people, by the fact that the streets of ancient Rome were decorated with rows of this tree, whence it was called Arbor populi. Again, it is asserted that the name is derived from the constant movement of the leaves, which are in perpetual motion, like the populace- " fickle, like the multitude, that are accursed."

P. tremula-Aspen. Gaelic and Irish : critheann, trembling.

"Mar chritheach san t' sine."-UI.L.

Like an aspen in the blast.

With the slightest breeze the leaves tremble, the poetic belief being that the wood of the Cross was made from this tree, and that ever since the leaves cannot cease from trembling. Eadhadh. Welsh : aethnen (athiad, smarting). The mulberry tree of Scripture is supposed to be the aspen (Balfour), and in Gaelic is rendered craobh nan smèur. (See Morus and Rubus fruticosus.)

"Agus an uair a chluineas tu fuim siubhail an mullach chroblu nan smiur, an sin gluaisidh tu thu féin." -2 SAMUEL v. 24.

And when thou hearest a sound of marching on the tops of the mulberry trees, that then thou shalt bestir thyself.

The badge of Clan Fergusson.

Salix-According to Pictet, from Sanskrit, sâla, a tree.

"Il a passe au suale dans plusieurs langues

. . Ces noms derivent de sâla."

Gaelic and Irish : seileach, saileog, sal, suil. Cognate with Latin: salix. Fin.: salarea. Anglo-Saxon: salig, salh, from which

'See Canon Bourke's work on 'The Aryan Origin of the Gaelic Race and Language.' London : Longman. 
sallow (white willow) is derived. Welsh: helyg, willow. (See S. viminalis.)

S. viminalis - Osier willow; cooper's willow. Gaelic and Irish: fineamhain (from fin, vine; and muin, a neck), a long twig-a name also applied to the vine. ${ }^{1}$ Vimen in Latin means also a pliant twig, a switch osier. One of the seven hills of Rome (Viminalis Collis) was so named from a willow copse that stood there ; and Jupiter, who was worshipped among these willows, was called "Viminius;" and his priests, and those of Mars, were called Salii for the same reason. The worship was frequently of a sensual character, and thus the willow has become associated with lust, filthiness. Priapus was sarcastically called "Salacissimus Jupiter," hence salax, lustful, salacious; and in Gaelic, salach (from sal); German, sal, polluted, defiled. The osier is also called bunsag, bun, a stump, a stock. Maothan, from maoth, smooth, tender. Gall sheileach, the foreign willow.

S. caprea, and S. aquatica-Common sallow. Gaelic and Irish : suilleag, probably the same as Irish, saileog (Anglo-Saxon, salig, sallow). Siìl-the old Irish name-(in Turkish su means water) in Irish and Gaelic, the eye, look, aspect, and sometimes tackle (Armstrong). The various species of willow were extensively used for tackle of every sort. Ropes, bridles, \&c., were made from twisted willows. "In the Hebrides, where there is so great a scarcity of the tree kind, there is not a twig, even of the meanest willow, but what is turned by the inhabitants to some useful purpose."-WaLKeR's 'Hebrides.' And in Ireland to this day "gads," or willow ropes, are made. Gealsheileach (Armstrong), the white willow or sallow tree. Irish: crann sailigh fhrancaigh, the French willow.

S. babylonica-The Babylonian willow. Gaelic: seileach an $t^{\prime}$ srutha (sruth, a brook, stream, or rivulet), the willow of the brook.

" Agus gabhaidh sibh dhuibh féin air a' cheud là meas chraobh àluinn, agus seileach an $t$ ' srutha."-LEv. xxiii. 40 .

And take unto yourselves on the first day fruit of lovely trees, and willows of the brook.

\section{MYRICACE}

Myrica gale-Bog myrtle, sweet myrtle, sweet gale. Gaelic: rideag. Irish : rideog, rileog (changing sound of $d$ to $l$ being

1 "Finemhain fa m' chomhair" (in Genesis)-a vine opposite to me. 
easier). Rod or roid is the common name in the Highlands, perhaps from the Hebrew, רתמ, rothem, a fragrant shrub. It is used for numerous purposes by the Highlanders, e.g., as a substitute for hops; for tanning; and from its supposed efficacy in destroying insects, beds were strewed with it, and even made of the twigs of gale, which is there called nodha. "And to this day it is employed by the Irish for the same purpose by those who know its efficacy. The rideog is boiled and the tea or juice drank by children to kill 'the worms.' I think children educated in our national schools should be taught to know these plants and their value."-Canon BOURKE.

Badge of the Clan Campbell.

\section{CONIFERE.}

Pinus-French : le pin. German : pyn-baum. Italian: il pino. Spanish : el pino. Irish : pinn chrann. Gaelic: pin-chrann. Anglo-Saxon: pinu. All these forms of the same name are derived, according to Pictet, from the Sanskrit verb pina, the past participle of pita, to be fat, juicy. From pina, comes Latin, pinus, and the Gaelic, pin.

P. sylvestris - Scotch pine, Scots fir. Gaelic: giithas, giiubhas.

"Mar giübhas a lùb an doinionn."-Ossian.

Like a pine bent by the storm.

Givithas, probably from the same root as picea, pitch pine. Sanskrit: pish, soft, juicy. Gaelic : givibhas, a juicy tree,-from the abundance of pitch or resin its wood contains; Con or cona (O'Reilly), from Greek : $\chi \omega \nu o s, k o n o s$, a cone, a pine. Hence conadh, fire-wood. Fir in English, from Greek, $\pi \hat{v} \rho$, fire, because good for fire.

Badge of the Macgregors-Clan Alpin.

P. picea-Silver pine. Gaelic: giubhas geal (Fergusson), white pine. First planted at Inveraray Castle in I682.

Abies communis-Spruce-fir. Gaelic: guithas Lochlannach, Scandinavian pine.

"Nuair theirgeadh giubhas Lochlainneach."-M 'CODRUM.

When the spruce fir is done.

Lochlannach, from loch, lake, and lann, a Germano-Celtic word meaning land-i.e., the lake-lander, a Scandinavian. 
" Giubhas glàn na Lòchlainn,

Fuaight' le copar ruadh."

Polished fir of Norway,

Bound with reddish copper.

P. larix-Larch. Gaelic and Irish : laireag. Scotch : larick. Latin: larix, from the Celtic, làr, fat, fron the abundance of resin the wood contains. Welsh: larswydden, fat wood.

P. strobus-(Strobus, a name employed by Pliny for an eastern tree used in perfumery) Weymouth pine. Gaelic : giiuthas Sasunnach (Fergusson), the English pine. It is not English, however; it is a North American tree, but was introduced from England to Dunkeld in 1725 .

Cupressus-Cypress. Irish and Gaelic: cuphair, an alteration of Cyprus, where the tree is abundant.

C. sempervirens-Common cypress. Gaelic: craobh bhroin, the tree of sorrow. Bròn, grief, sorrow, weeping. Craobh uaine ginthais, the green fir-tree.

"Is cosmhuil mi ri crann uaine giuthais."-HoseA xiv. 8. I am like a green fir-tree.

The fir-tree of Scripture (Hebrew berosh and beroth are translated fir-trees) most commentators agree is the cypress.

Thuja articulata-Thyine wood. Gaelic : fodh-thine.

"Agus gach uile ghnè fhiodha thine."-REv. xviii. I2.

And all kinds of thyine wood.

Alteration of thya, from $\theta v \omega$, to sacrifice. Another kind of pine, Hebrew, oren (Irish and Gaelic, oruin), is translated ash in Isaiah xliv. I4, and beech by O'Reilly.

Cedar-(So called from its firmness.) Hebrew : ארץ, crez. Cedrus Libani, cedar of Lebanon. Gaelic and Irish: crann sheudar, cedar-tree.

"Agus air uile sheudaraibh Lebanoin."-IsaiaH ii. I3.

And upon all the cedars of Lebanon.

The cedar wood mentioned in Lev. xiv. 4, was probably Juniperus oxycedrus, which was a very fragrant wood, and furnished an oil

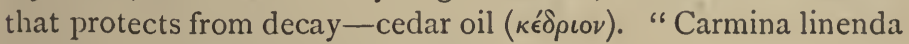
cedro "-i.e., worthy of immortality.

"Agus fiodh sheudar, agus scàrlaid, agus hiosop." And cedar wood, scarlet, and hyssop. 
Juniperus-Said to be "from the Celtic jeneprus, which signifies rough or rude" (Loudon), a word not occurring in any Celtic vocabularies that I have consulted. It seems to be the Latinised form of the Celtic root iu, iubh, iurr, yw (see Taxus). From the same root comes yew in English. Irish: iubharbeinne (O'Reilly), the hill yew; iubhar-talamh, the ground yew; ubhar-chraige, the rock yew; all given as names for the juniper. Juniperus is mentioned by both Virgil and Pliny. Both the Greeks and Romans reluctantly admitted that they were indebted to the Celts for many of their useful sciences, and even their philosophy (see Diogenes Laertius), as they certainly were for their plant and geographical names.

J. communis-Juniper. Gaelic and Irish : aiteil, aitinn, aitiol.

"Ach chaidh e fèin astar làtha do"n fhasach agus thàinaig e agus shuidh e fuidh craobh aiteil." -1 KINGS xix. 4.

And he went a day's journey into the desert, and he sat under a juniper tree.

The juniper of Scripture, Genista monosperma, was a kind of broom. Aiteil, from ait. Welsh: aeth, a point, furze. Irish: aiteann, furze, from its pointed leaves. Bior leacain (in Arran), the pointed hill-side plant. Staoin (in the North Highlands), caoran staoin, juniper berries (staoin, a little drinking-cup).

The badge of Clans Murray, Ross, M'Leod, and the Athole Highlanders.

J. sabina-Savin. Gaelic : samhan (Armstrong), alteration of "sabina" the "sabina herba" of Pliny. Common in Southern Europe, and frequently cultivated in gardens, and used medicinally as a stimulant, and in ointments, lotions, \&c.

Taxus-According to Benfey is derived from the Sanskrit, taksh, to spread out, to cut a figure, to fashion. Persian tak. Greek : $\tau o \xi o s$, an arrow. Irish and Gaelic : tuagh, a bow made of the taxos or yew, now applied to the hatchet used in place of the old bow.

T. baccata - Common yew. Gaelic and Irish : iuthar, iubhar, iughar, from iui. Greek: iós, an arrow, or anything pointed. Arrows were poisoned with its juice; hence in old Gaelic it was called $i o g h$, a severe pain, and ioghar (Greek, ‘ $\chi \omega \rho$, ichor) pus, matter. The yew was the wood from which ancient bows and arrows were made, and that it might be ready at hand, it was planted in every burial-ground. 
"' $\mathrm{N}$ so fein, a Chuchullin, tha' $\mathrm{n}$ ùir,

'S caoin iuthar 'tha 'fàs o'n uaigh." 1 -Ossian.

In this same spot Chuchullin, is their dust,

And fresh the yew tree grows upon their grave.

Hence another form of the name eo, a grave. Sinsior, sinnsior (O'Reilly), long standing, antiquity, ancestry. The yew is remarkable for its long life. The famous yew of Fortingall in Perthshire, which once had a circumference of $5^{61 / 2}$ feet, is supposed to be 3500 years old. Sineadhfeadha (O'Reilly), protracting, extending.

The badge of Clan Fraser.

\section{E N D O G E N S.}

\section{ORCHIDACE}

Orchis-Greek: ö $\rho \chi \iota s$, a plant with roots in the shape of testicles. "Mirabilis est orchis herba, sive serapias, gemina radice testiculis simili"-PLINY.

0. maculata-The spotted orchis. Gaelic and Irish : irrach bhallach, from iir, fresh ; irach, a bottle ; uradh, apparel, and ballach, spotted.

0. mascula-Early orchis. Gaelic: moth-ìrach, from mòth, the rnale of any animal.

"Lointeann far an cinn

I'na moth'raichean." -M'INTYRE in 'Ben Doran.'

Meadows where the early orchis grow.

Irish: magairlin meireach, (magairle, the testicles; meireach (Greek, meiro), joyful, glad). Clachan gadhair (gadhar a hound, clach, a stone). The name, cuigeal an losgain, the frog's spindle, is applied to many of the orchis; and frequently the various names are given to both maculata and mascula.

o. conopsea - Fragrant orchis. Gaelic: lus tòghta, the chosen or select weed.

Ophrys-Greek : oфpús (Gaelic, abhra), the eyelash, to which the delicate fringe of the inner sepals may be well compared. "A plant with two leaves"-FreUnd.

1 Laing is not correct when, in attacking the genuineness of the poems of Ossian, he asserts that the yew, so often mentioned in these poems, is not indigenous. There are various places, such as Gleniur, Duniur, \&c., that have been so named from time immemorial, which prove that the yew was abundant in these places at least many centuries ago. 
0. or Listera ovata-Tway blade. Gaelic: dà-dhuilleach, two-leaved; dà-bhileach, same meaning.

Epipactis latifolia-White helleborine. Gaelic : 'elebor-geal. ${ }^{1}$ A plant used formerly for making snuff. "The root of hellebor cut in small pieces, the pouder drawne vp into the nose causeth sneezing, and purgeth the brain from grosse and slimie humors" -GERARD, 1597. This is probably the plant referred to in "Morag," when M'Donald describes the buzzing in his head, for even his nose he had to stop with hellebore, since he parted from her endearments.

\section{" Mo cheann tha làn do sheilleanaibh \\ O dheilich mi ri d'bhriodal \\ Mo shròn tha stoipt' á dh-elebor. \\ $\mathrm{Na}$ deil, le teine dimbis."}

\section{IRIDACEE.}

Iris-Signifying, according to Plutarch, the "eye." Canon . Bourke maintains "it is derived from '́ $\iota \omega$, to settle. And as a name it was by the pagan priests applied to the imaginary messenger, sent by gods and goddesses to others of their class, to announce tidings of goodwill. At times they imagined her sent to mortals, as in Homer, to settle matters, or to say they were destined to be settled. Such was the duty of IRIs. Now amongst Jews and Christians, the rainbow was the harbinger of peace to man, hence it was called 'Iris;' and the circle of blue, grey, or variegated tints around the pupil of the eye is not unlike the rainbow-therefore this circlet was so called by optic scientists, simply because they had no other word; and botanists have, by comparison, applied it to the fleur-de-lis, because it is varied in hue, like the iris of the eye, or the rainbow. Iris does not and did not convey the idea of eye."

I. pseudacorus - The yellow flag. Gaelic : bog-uisge-bog, soft, but here a corruption of bogha-uisge, the rainbow. Gaelic and Irish: seilisdear, often seileasdear, and siolastar. The termination, tar, dear, or astar, in these names, means one of a kind, having a settled form or position. One finds this ending common in names of plants-as, oleaster, cotoneaster, \&c., like " $\eta \eta \rho "$ in Greek, "fear" in Gaelic. Scil (the first syllable), from sol, the sun; solus, light; sol and leus, i.e., lux, light. Greek : "H $\mathrm{\lambda} \cos$ ( $\eta$ or $e$ long), hence seìl, $e$ and $i$ to give a lengthened sound,

${ }^{1}$ See Helleborus viridis. 
as in Greek. Seileastar, therefore, means the plant of lightFleur de luce. Other forms of the word occur. Siol instead of seil, as siolstrach; siol or sil, to distil, to drop-an alteration probably suggested by the medicinal use made of the roots of the plant, which were dried, and made into powder or snuff, to produce salivation by its action on the mucous membrane. "Feileastrom, feleastrom, feleastar. Here $f$ is the affected or digammated form. When eleastar (another form of the word) lost the ' $s$,' then, for sound's sake, it took the digammated form (f)eleastar. Strom (the last syllable) is a diminutive termination. Seilistear, diminutive form seilistrin, and corrupted into seilistrom"-BOURKE.

Crocus-Greek : кро́коs. Much employed amongst the ancients for seasonings, essences, and for dyeing purposes.

$\left.\begin{array}{l}\text { C. sativus } \\ \text { Colchicum autumnale }\end{array}\right\}$-Saffron crocus, meadow saffron. Gaelic and Irish : crò, cròdh, cròch-cròdh chorcar. ${ }^{1}$

"'Se labhair Fionn nan chrò-shnuaidh."-Conn MAC DEARG.

Thus spake Fingal the saffron-hued.

" Spiocnard agus croch."-DaNa Sholhim, iv. I4.

Spikenard and saffron.

Saffron was much cultivated anciently for various purposes, but above all for dyeing. "The first habit worn by persons of distinction in the Hebrides was the lein croich, or saffron shirt, so called from its being dyed with saffron." - WALKER. The Romans had their crocota, and the Greeks o крокшто́s, a saffron-coloured court dress. Welsh: saffrwm, saffron, from the Arabic name, $z^{\prime}$ afarân, which indicates that the name of the plant is of Asiatic origin.

\section{AMARYLLIDACEÆ.}

Narcissus pseudo-narcissus " jonquilla

-Daffodil. Gaelic : lus a chròmchinn, the plant having a bent or drooping head.

Galanthus nivalis - Snowdrop. Gaelic and Irish : gealag lair,_-gealag, white as milk; làr, the ground. Galanthus.

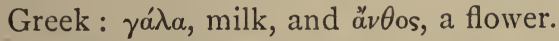

Aloe-Hebrew, אהלות, ahaloth. Gaelic and Irish: aloe.

"Leis na h-uile chraobhaibh tuise, mirr agus aloe."

With all trees of frankincense; myrrh, and aloes.-SoNG of Solomon, iv. 14 .

${ }^{1}$ For corcur, see Lecanora tartarea. 
The aloe of Scripture ${ }^{1}$ must not be confounded with the bitter herb well known in medicine.

\section{LILIACEA.}

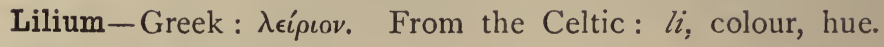
Welsh : lliu. Gaelic: li.

"A mhaise-mhna is ailidh $l i$ !"-Fingalian Poems.

Thou fair-faced beauty.

"Lily seems to signify a flower in general." - WEDGEWOOD. Gaelic and Irish : lilidh or lili.

Convallaria majalis-I.ily of the valley. Gaelic: lili nan lòn. Lili nan gleann.

"Air ghilead, mar lili nan lointean."-M 'Donald.

White as the lily of the valley.

"Is ròs Sharon mise lili nan gleann."-STUART.

I am the rose of Sharon, the lily of the glen.

"The lily of Scripture was probably Lilium chalcedonicum."BALFOUR.

Allium-The derivation of this word is said to be from all (Celtic), hot, burning. There is no such word. The only word that resembles it in sound, and with that signification, is sgallta, burned, scalded; hence, perhaps, "scallion," the English for a young onion. Latin : calor.

A. cepa (cep, Gaelic: ceap, a head) - The onion. Gaelic : uinnean. Irish: oinninn. Welsh: wynwyn. French: oignon. German : önjön. Latin : unio. Gaelic: siobaid, siobann. WVelsh: sibol. Scotch: sybo. German: zuiebel, scallions or young onions. Cutharlan, a bulbous plant. In Lorne, and elsewhere along the W. Highlands, frequently called Sroniamh (probably from Sron and amh, rawe in the nose, or pungent in the nose).

A. porrum ${ }^{2}$-Garden leek. Gaelic and Irish: leigis, leiceas, leicis. German : lauch, leek.

"Agus na leicis agus na h'uinneinean."-NumBers, xi. 5.

And the leeks and the onions.

Irish : bugha (Shaw), leeks, fear. O'Clery, in his 'Vocabulary,' published A.D. 1643 , describes it thus: "Bugh, i.e., luibh gorm nó glàs ris a samhailtean sùile bhios gorm no glàs." That is, a blue or grey plant, to which the eye is compared if it be blue or

1 Aquilaria agallochum.

2 "Porrum" from the Celtic, pori, to eat, to graze, to browse. 
grey. The resemblance between a leek and the eye is not very apparent, as the following quotation shows :-

"Dhearca mar dhlaoi don bhugha,

Is a dha bhraoi cearta caol-dhubha."-O'Brien.

His eyes like a bunch of leeks,

And his two eyebrows straight, dark, narrow.

Although Shaw gives the name to leek, probably the plant referred to is the harebell (see Scilla non-scripta). Irish: coindid, coinne, cainnen. Welsh : cenin (cen, a skin, peel, scales, given to onions, garlic, leeks).

"Do roidh, no do coindid, no do ablaibh."

Thy gale, nor thy onions, nor thy apples.

Coindid, though applied to leeks, onions, \&c., means seasoning, condiments, Latin : condo.

A. ursinum-Wild garlic. From the Celtic. Gaelic and Irish : gurleag. Welsh: garlleg, from gar, gairce, bitter, most bitter. Gairgean. Creamh (Welsh, craf), cream, to gnaw, chew. Lurachan, the flower of garlic.

"Le d' lurachain chreamhach fhàson

" 'Sam buicein bhàn orr' shuas." -M‘DoNALD.

The feast of garlic, "Fèisd chreamh," was an important occasion for gatherings and social enjoyment to the ancient Celts.

"Ann's bidh creamh agus sealgan, agus luibhe iomdha uile fhorreas, re a $\mathrm{n}$-itheadh úrghlas feadh na bleadhna ma roibhe ar teitheadh ó chaidreath na n-daoine, do 'n gleann dà loch." - IRISH.

Where garlic and sorrel, and many other kinds, of which I ate fresh throughout the year before I fled from the company of men to the glen of the Two Lochs. ${ }^{1}$

A. scorodoprasum-Rocambole. Gaelic and Irish : creamh nan crag (M'Kenzie), the rock garlic.

A. ascalonicum-Shallot. Gaelic: sgalaid (Armstrong). (See Allium).

A. schœnoprasum-Chives. Gaelic: feuran. Irish : fearan, the grass-like plant. Saidse. Creamh ghàralh, the garden garlic. Welsh : cenin Pedr, Peter's leek.

A. vineale-Crow garlic. Gaelic: garleag Mhuire (Armstrong), Mary's garlic.

1 A most gloomy and romantic spot in the County of Wicklow.

"Glen da lough! thy gloomy wave,

Soon was gentle Kathleen's grave."--Moore. 
Narthecium ossifragum-Bog asphodel. Gaelic and Irish : blioch, bliochan, from blioch, milk. Welsh : gweaew'r trenin, king's lance.

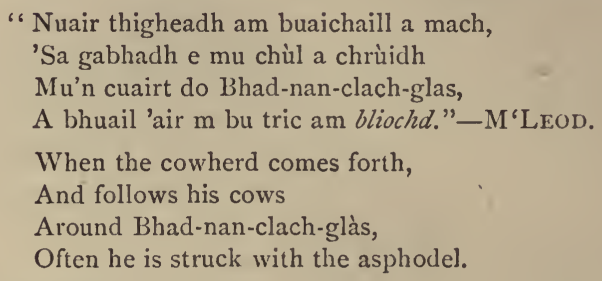

"Nuair thigheadh am buaichaill a mach,

'Sa gabhadh e mu chùl a chrùidh

Mu'n cuairt do Bhad-nan-clach-glas,

A bhuail 'air $m$ bu tric am bliochd."-M'LEOD.

When the cowherd comes forth,

And follows his cows

Around Bhad-nan-clach-glàs,

Often he is struck with the asphodel.

Scilla non-scripta_Bluebell; wild hyacinth. Gaelic: fuath mhuic, the pig's fear or aversion, the bulbs being very obnoxious to swine. Brog na cubhaig, cuckoo's shoe. Irish : buth a muc. Probably buth is the same as bugha (see Allium porrum), fear, the pig's fear. M'Lauchainn called it lili gucagach.

\section{" Lili gucagach nan cluigean." \\ The bell-flowered lily.}

S. verna - Squill (and the Latin, scilla, from the Arabic, assyl). Gaelic: lear uineann, the sea-onion. Lcar, the sea, the surface of the sea.

"Clos na min-lear uaine."-Ossian.

The repose of the smooth green sea.

Welsh : winzeyn y mor, sea-onion.

Tulipa sylvestris-Tulip. Gaelic: tuiliop. The same name in almost all European and even Asiatic countries. Persian : thouilybân (De Souza).

Asparagus officinalis-Common asparagus. Gaelic : cream/ mac-fiadh. Irish : creamh-miic fadh, wild boar's leek or garlic. The same name is given to hart's tongue fern. Aspàrag, from the generic name $\sigma \pi \alpha \rho a \sigma \sigma \omega$, to tear, on account of the strong prickles with which some of the species are armed.

Ruscus-Latinised form of Celtic root rus, wood, husk; rusgach, holly. Welsh: rhy'sgiad, an over-growing. Also bruscus, from Celtic, brus, bruis, small branches, brushwood.

R. aculeatus - Butcher's broom. Gaelic: calg-bhrudhaimn (Armstrong). Irish : calg-bhrudhan (Shaw)--calg, a prickle, from its prickly leaves; and bruth, bruid, a thorn, anything pointed; brudhan, generally spelled brughian, a faggot. Or it may only be a corruption from brum, broom. Calg bhealaidh, the prickly broom. It was formerly used by butchers to clean their blocks, hence the English name "butchers' broom." 


\section{NAIADACE.}

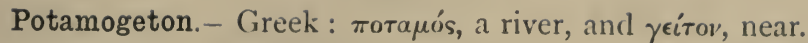

P. natans - Broad-leaved pondweed. Gaelic: duiliasg na l'aiblne, the river leaf. Most of the species grow immersed in ponds and rivers, but flower above its surface. Liobhag, from liobh, smooth, polish, from the smooth pellucid texture of the leaves, their surface being destitute of down or hair of any kind. Irish : liachroda,-liach, a spoon, rod, a water-weed, sea-weed; liach-Brighide, Bridget's spoon. Probably these names were also given to the other species of pondweeds (such as $P$. polygonifolius) as well as to $P$. natans.

Zostera marina-The sweet sea-grass. Gaelic and Irish : bilearach (in Argyle, bileanach), from bileag, a blade of grass. The sea-grass was much used for thatching purposes, and it was supposed to last longer than straw.

\section{Alismace瓜.}

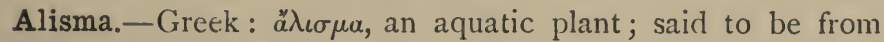
a Celtic root, alis, water. If ever this was a Celtic vocable it has ceased to have this signification: in Welsh alis means the lowest point, hell.

A. Plantago-Water-plantain. Gaelic and Irish : cor-chopaig (cor or cora, a weir, a dam, and copag, a dock, or any large leaf of a plant). It grows in watery places. Welsh: llyren, a duct, a brink or shore.

Triglochin palustre-Arrow-grass. Gaelic : bàrr a' mhilltich,-

"Bun na cipe is birrr a' mhilltich."-M'INTYre.

bìrr, top, and milltich (Irish), "good grass," and milneach, a thorn or bodkin-hence the English name arrow-grass. Generic name from $\tau \rho \epsilon \hat{i}$, three, and $\gamma \lambda \omega \chi^{i}$ s, a point, in allusion to the three angles of the capsule. Sheep and cattle are fond of this hardy species, which afford an early bite on the sides of the Highland mountains. Milltich is commonly used in the sense of "grassy;" maghanan millteach, verdant or grassy meadows.

\section{LEMNACEÆ.}

Lemna minor-Duckweed. Gaelic : ${ }^{1}$ mac gun athair, son without a father. Irish: lus gan athair gan mhathair, fatherless motherless wort. A curious name, perhaps suggested by the

${ }^{1}$ Mac-gun-athair may have originally been meacan air,-meacun, a plant, air, gen. of $a r$, slow (hence the name of the river "Arar" in France, meaning the slow-flowing river,- "Arar dubitans qui suos cursos agat"SENECA), the plant that grows in slow or sluggish water. 
root being suspended from its small egg-shaped leaf, and not affixed to the ground. Gran-lachan,-gran, seed, grain,' and lach, a duck. The roundish leaves, and the fact that ducks are voraciously fond of feeding on them, have suggested this and the following names : Ros lachain, the ducks' rose or flower. Irish : abhran donog (O'Reilly), —abhran is the plural of abhra, an eyelid, and donog, a kind of fish, a young ling. . The fish's eyelids; more likely a corruption of aran tunnaig, duck's bread or meat.

It was used by our Celtic ancestors as a cure for headaches and inflammations.

\section{ARACEÆ.}

Arum, formerly aron, probably from the ancient Celtic root ar, land, earth; hence Latin, aro, to plough, and Gaelic, aran, bread, sustenance. The roots of many of the species are used both for food and medicine.

A. maculatum-Wake-robin, lords and ladies. Gaelic : cluas chaoin, the soft ear (caoin, soft, smooth, gentle, \&c., and chuas, ear). The ear-shaped spathe would probably suggest the name. Cuthaidh, from cuth, a head, a bulb-hence cutharlan, any bulbous-rooted plant. Cuthaidh means also wild, savage. Gachar and gaoicin cuthigh are given in O'Reilly's Dictionary as names for the Arum, from cai, a cuckoo. Old English : cuckoo's pint.

\section{ORONTIACE\&.}

Acorus calamus-Sweet-flag. Gaelic : cuilc-mhilis, sweet-rush ;

"Cuilc mhilis agus canal."

Calamus and cinnamon.

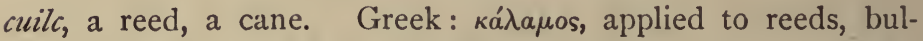
rush canes, e.g., cuile na Léig, the reeds of Lego. Cobhan cuilc, an ark of bulrushes. Cuilc-chrann, cane; milis (Greek: $\mu \in \lambda_{\iota} \sigma \sigma a$, a bee), sweet. Before the days of carpets, this plant is said to have supplied the "rushes" with which it was customary to strew the floors of houses, churches, and monasteries.

\section{TYPHACEÆ.}

Typha, from Greek, $\tau$ $\phi o s$, a marsh in which all the species naturally grow.

T. latifolia-Great reed-mace or cat's-tail. Gaelic and Irish : bodan dubh, from bod, a tail, and dubh, large, or dark. Cuigeal nam bàn-sith, the fairy-woman's spindle. It is often, but incorrectly, called bog bhuine or bulrush (see Scirpus lacustris). The downy seeds were used for stuffing pillows, and the leaves for making 
mats, chair-bottoms, thatch, and sometimes straw hats or bonnets.

T. angustifolia-Lesser reed-mace or cat's-tail. Irish : bodan (O'Reilly), dim. of bod, a tail.

Sparganium.-Name in Greek denoting a little band, from the ribbon-like leaves.

S. ramosum-Branched bur-reed. Gaelic: righ seisg, the king's sedge, from its being a large plant with sword-shaped leaves. Seisg mheirg (Stewart), - meirg, rust, a standard or banner.

S. simplex - Upright bur-reed. Gaelic: seisg madraidh. Armstrong gives this name to $S$. erectum, by which he doubtless means this plant. Seisg, sedge, and madradh, a dog, a mastiff. Name probably suggested by the plant being in perfection in the dog-days, the month of July, mios Mhadrail.

\section{JUNCACEÆ.}

Juncus, from the Latin jungo, to join. The first ropes were made from rushes, and also floor covering. Ancient Gaelic: aoin, from aon, one. Latin: unus. Greek: $\epsilon \nu$. Ger.: ein.

\footnotetext{
"A dàth amar dhàth an aeil, Coilcigh eturra agus aein. Sída eturra is brat gorm, Derg ór eturra is glan chorn."
}

(From the description of the Lady Crehé's house by Caeilté MacRonain, from the Books of Ballymote, a rare ancient poem.)

The colour [of her din] is like the colour of lime :

Within it are couches and green rushes;

Within it are silks and blue mantles;

Within it are red gold and crystal cups.

J. conglomeratus-Common rush. Gaelic and Irish : luachar, a general name for all the rushes, meaning splendour, brightness; hence luachar, a lamp. Latin: lucerna. Sanscrit: lauchanan, from the root, lauch, light. The pith of this and the next species was commonly used to make rush-lights. The rushes were stripped of their outer green skin, all except one narrow stripe, and then they were drawn through melted grease and laid across a stool to set. "The title Luachra was given to the chief Druid and magician, considered by the pagan Irish as a deity, who opposed St Patrick at Tara in the presence of the king and the nobility, who composed the convention "- 'Life of St Patrick.' Brog braidhe (O'Reilly), - bròg, a shoe; but here it should be brodh, straw ; braidhe, a mountain, the mountain straw or stem. 
J. etfusus-Soft rush. Gaelic : luachar bogr, soft rush. Irish : feath, a bog. It grows best in boggy places. Fead, which seems to be the same name, is given also to the bulrush. Fead, a whistle, a bustle.

" 'S lionmhor feadan caol,

Air an éirich gaoth." - M'INTYRE.

Doubtless suggested by the whistling of the wind among the rushes and reeds. The common rush and the soft rush were much used in ancient times as bed-stuffs; they served for strewing floors, making rough couches, \&c.

J. articulatus-Jointed rush. Gaelic: lochan nan damh. This name is given by Lightfoot in his 'Flora Scotica,' but it should have been lachan nan damh. Lachan, a reed, the ox or the hart's reed.

J. squarrosus-Heath-rush, stool-bent. Gaelic : bru-corcur (M'Alpine),-bru-chorachd, the deers' moor-grass; bru, a deer, a hind; corcach, a moor or marsh. See Scirpus.

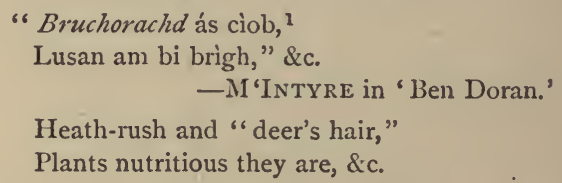

Specimens of this plant have also been supplied with the Gaelic name moran labelled thereon, and in another instance muran. These names mean the plants with tapering roots; the same signification in the Welsh, moron, a carrot. (See MuirneachAmmophila arenaria.)

J. maritimus and acutus-Sea-rush. Irish : meithan (O'Reilly). Meith, fat, corpulent. $J$. acutus (the great sea-rush) is the largest British species.

Luzula.-Name supposed to have been altered from Italian, lucciola, a glow-worm. It was called by the ancient botanists gramen luxula (Latin, lux, light).

I. sylvatica-Wood-rush. Gaelic : luachar coille, the bright grass or rush of the wood. The Italian name lucciola is said to be given from the sparkling appearance of the heads of flowers when wet with dew or rain. Learman (Stewart), possibly from lear or léir, clear, discernible; a very conspicuous plant, more of the habit of a grass than a rush, the stalk rising to the height of more that two feet, and bearing a terminal cluster of brownish flowers, with large light-yellow anthers.

\footnotetext{
${ }^{1}$ See Scirpus caspitosus.
} 


\section{CYPERACE.}

Schœnus (from xoîvos or $\sigma$ Xoivos, a cord in Greek).-From plants of this kind cords or ropes were made.

S. nigricans - Bog-rush. Gaelic: seimhean (Armstrong). Irish: seimhin (seimh, smooth, shining - the spikelets being smooth and shining; or which is more likely, from siobh or siobhag, straw,-hence sioman, a rope made of straw or rushes; the Greek name $\sigma \chi_{\text {oivos }}$ for the same reason).

Scirpus, sometimes written sirpus (Freund), seems to be cognate with the Celtic cirs, cors, a bog-plant; hence Welsh, corsfruyn, a bulrush (Gaelic, curcais). Many plants of this genus were likewise formerly used for making ropes. (Cords, Latin, chorda; Welsh, cord; Gaelic and Irish, corda; Spanish, cuerda,-all derived from cors.)

S. maritimus-Sea-scirpus. Gaelic and Irish : bròbh. Name from brò, brà, or bràdh, a quern, a hand-mill. The roots are large and very nutritious for cattle, and in times of scarcity were ground down in the muileann bràdh (French, moulin à bras), to make meal; bracan, broth,-hence bracha, malt, because prepared by manual labour (Greek, Bpaxi $\omega v$; Latin, brachium; Gaelic, braic; French, bras, the arm).

S. cæspitosus-Tufted scirpus, deer's hair, heath club-rush. Gaelic: ciob, cipe, and ciob cheann dubh (ciob $=\chi \iota$ ßos; Latin, cibus, food; ceann, head; dubh, black).

\section{" Le'n cridheacha' meara \\ Le bainne na cioba. '-M'INTYRE.}

This is the principal food of cattle and sheep in the Highlands in March, and till the end of May. Cruach luachair,-cruach, a heap, a pile, a hill, and luachair, a rush.

The badge of the Clan M'Kenzie.

S. lacustris-Bulrush, lake-scirpus. Gaelic: gobhal luachair, the forked rush (gobhal, a fork), from the forked or branched appearance of the cymes appearing from the top of tall, terete (or nearly so), leafless stems. When this tall stem is cut, it goes by the name of cuilc, ${ }^{1}$ a cane, and is used to bottom chairs. Irish : gibiun, - gib or giob, rough, and aoin, a rush. Gaelic and Irish, bog mhuine, boigean, bog luachair, bog, ${ }^{2}$ a marsh, a fen, swampy ground, to bob, to wag, -names indicating its habitat,

1 "Mu lochan nan cuilc a tha ruadh."-Tighmora.

$2 \mathrm{Bdg}$ and $b \dot{l g}$ are frequently interchanged: bolg luachair, prominent or massy rush; from bòlg, gen. builg, comes bul in bulrush. 
also its top-heavy appearance, causing it to have a bobbing or wagging motion. Curcais (curach, a marsh, a fen) is more a generic term, and equals scirpus. Min-fheur, a bulrush. (See Festuca ovina.)

Badge of Clan M'Kay.

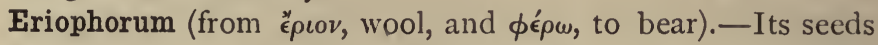
are covered with a woolly substance-hence it is called cottongrass.

E. vaginatum and E. polystachyon-Cotton-sedge. Scotch: cat's-tail. Gaelic and Irish : canach. Irish : cona (from can, white), from its hypogynous bristles forming dense tufts of white cottony down, making the plant very conspicuous in peaty bogs. The canaich in its purity and whiteness formed the object of comparison in Gaelic poetry for purity, fair complexion, \&c., especially in love-songs :-

"Do chneas mar an canach

Co cheanalta thlà." -M'INTYRE.

Thy skin white as the cotton-grass

So tender and gentle.

"Bu ghile na'n canach a crùth."-Ossian.

Her form was fairer than the down of Cana.

In Ossian the plant is also called caoin cheann (caoin, soft), the soft heads, fair heads.

\footnotetext{
"Ghlac mi'n caoin cheanna sa' bheinn

'Siad ag aomadh mu shruthaibh thall

Fo charnaibh, bu diomhaire gaoth." -TigHMora.

I seized cotton-grasses on the hill,

As they waved by their secret streams,

In places sheltered from the wind.
}

This is only the plural form of the name canach-caineichean.

"Na caineichean àluinn an t-shléibh." -M'LEOD.

O'Reilly gives the name sgathog fiadhain to $E$. polystachyon,sgath, a tail, and og (dim. termination), the little tail,- - to distinguish it from vaginatum, which is larger. Scotch : cat's-tail.

Badge of Clan Sutherland.

Carex (likely from. Welsh, cors; Caelic,càrr, a bog, a marsh, or fenny ground).- This numerous family of plants grows mostly in such situations. Seisg, sedge ; gallsheilisdear, also seilisdear amh (for Seilisdear, see Iris), - amh, raw - the raw sedge. Welsh : hesg. Seasg, barren, unfruitful. Except C. rigida, they 
are scarcely touched by cattle. According to Dr Hooker, carex is derived from Greek, кєip $\omega$, from the cutting foliage. The Sanscrit root is kar, to cut, shear, divide.

C. vulgaris, and many of the other large species-Common sedge. Gaelic: gainnisg (Stewart), - gainne, a sedge, reed, cane, arrow ; and seasg.

\section{GramineÆ.}

Agrostis alba-Fiorin-grass. Gaelic and Irish : foran, feorine, or fior-than; derived from Gaelic: feur, feoir, grass, herb. age, fodder. Latin : vireo, I grow green, -ver, spring ; fonum, fodder $-r$ and $n$ being interchangeable. This name is applied in the dictionaries to the common couch-grass, because, like it, it retains a long time its vital power, and propagates itself by extending its roots.

Alopecurus-Foxtail-grass. Gaelic : fteag,-fit, food, refreshment. Latin: vita.

A. geniculatus.-Gaelic : fiteag chàm,-

"A chuiseag dheireach's an fhiteag cham."-M'INTYRE.

cam, bent, from the knee-like bend in the stalk. A valuable grass for hay and pasture.

Arundo Phragmites-Reed-grass. Gaelic: seasgan; seasg, a reed. Lachan, the common reed. Irish : cruisgiornach, cruisigh, music, song; from its stem reeds for pipes were manufactured. Welsh : cawen wellt, cane-grass; quellt, grass.

Anthoxanthum odoratum - Sweet meadow-grass. Gaelic: mislean, from milis, sweet.

\section{"'San canach min geal 's mislean ann."-M 'INTYRE.}

The soft white cotton-grass and the sweet grass are there.

Borrach (borradh, scent, smell).-In some places this name is given to the Nardus stricta, which see. This is the grass that gives the peculiar smell to meadow hay. Though common in meadows, it grows nearly to the top of the Grampians ( 3400 feet); hence the names are given as "a species of mountain grass" in some dictionaries.

Milium effusum - Millet-grass. Gaelic : mileid. Welsh : miled. The name derived from the true millet misapplied. Millet is translated in the Gaelic Bible meanbh pheasair, small peas (see Faba vulgaris).-Ezekiel iv. 9.

Phleum pratense-Timothy grass, cat's-tail grass. Gaelic: bodan, a little tail ; the same nanie for Typha angustifolia. "This 
grass was introduced from New York and Carolina in 1780 by Timothy Hanson."-Loudon. It seems to have been unknown in the Hebrides and the Highlands before that date; for Dr Walker ('Rural Econ. Hebrides,' ii. 27) says, "that it may be introduced into the Highlands with good effect." Yet Lightfoot ( 1777 ) mentions it as "by the waysides, and in pastures, but not common." Bodan is also applied to $P$. arenarium and $P$. alpinum.

Lepturus filiformis.-Gaelic : dur fheur fairge, sea hard grass. Dur, hard (Latin, durus) ; feur, grass ; fairg, the sea, ocean, wave. It grows all round Ireland, as well as in England and South Scotland. Irish : durfher fairge (O'Reilly).

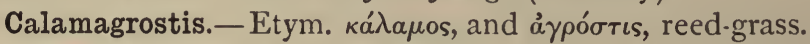

C. Epigejos-Wood small reed. Cuilc fheur, cane-grass; gainne = cane. Lachan coille, wood-rush.

Ammophila arenaria (or Psamma arenaria)-Sea-maram; seamatweed. Gaelic and Irish : muirineach, from muir (Latin mare, the sea), the ocean. It is extensively propagated to bind the sand on the sea shore; generally called miran on west coast. The same name is applied to the carrot, an alteration of moron-a plant with large tapering roots. M'Intyre alludes to "miran brighar," but whether he refers to the carrot or to this grass is a matter of controversy. Not being a seaside Highlander, he was more likely to know the carrot, wild and cultivated, far better than this seaside grass, and associating it with groundsel (a plant which usually grows rather too abundantly, wherever carrots are sown), makes it a certainty that he had not the "seamaram" in his mind. (See Daucus carota.)

Avena sativa - Oats. Gaelic and Irish: coirc. Welsh: ceirch. Armoric: querch. Probably from the Sanskrit karç, to crush.

"Is fhearr siol caol coirce fhaotuinn a droch fhearann na' bhi falamh."

Better small oats than nothing out of bad land.

The small variety, $A$. muda, the naked or hill oat, when ripe, drops the grain from the husk; it was therefore more generally cultivated two centuries ago. It was made into meal by drying it on the hearth, and bruising it in a stone-mortar, the "mileann bradh"-hand-mill or quern. Many of them may still be seen about Highland and Irish cottages.

A. fatua and pratensis-Wild oats. Gaelic : coirc fiadhain, wild oats ; coirc dubh, black oats. Also applied to the Brome grasses. 
" Do'n t-siol chruithneachd, chuireadh gu tiugh ;

Cha i' e' n fhiteng, no' ncoirc dulh." $-M$ 'DONALD.

When oats become black with blight, the name coirc dubh is applied, but especially to the variety called Avena strigosa.

Hordeum distichon-Barley; the kind which is in common cultivation. ("Barley" comes from Celtic bàr, bread, now obsolete in Gaelic, but still retained in Welsh-hence barn, and by the change of the vowel, beer.) Gaelic and Irish : eorna, orna. Irish : earn (perhaps from Latin, horreo, to bristle; Gaelic, òr, a beard)-O'Reilly. "The bearded or bristly barley;" "òrog," a sheaf of corn. Hordeum, sometimes written ordeum (Freund), is from the same root. "It was cultivated by the Romans for horses, and also for the army; and gladiators in training were fed with it, and hence called hordiarii." It is still used largely in the Highlands for bread, but was formerly made into "crowdie," properly corrody, from Low Latin, corrodium, a worry.

" Fuarag èorn ann' sàil mo bhroge,

Biadh a b' fhearr a fhuir mi riamh."

Barley-crowdie in my shoe,

The sweetest food I ever knew.

Irish : caineog, oats and barley-from cain (Greek, $\kappa \hat{\nu} \nu \sigma o s$; Latin, census), rent, tribute. Rents were frequently paid in "kind," instead of in money.

Secale cereale - Common rye. Gaelic and Irish : seagall. Greek : $\sigma \epsilon_{\chi} \alpha \lambda \eta$. Armoric: segal. French : seigle.

"An cruithneach agus an seagall."-Exonus.

The wheat and the rye.

Welsh : rhyg, rye.

Molinia cærulea - Purple melic-grass. Gaelic: bunglds (M'Donald), punglàs. (Bun, a root, a stack; glàs, blue.) The fishermen round the west coast and in Skye make ropes for their nets of this grass, which they find by experience will bear the water well without rotting. Irish : mealoigfer corcuir (O'Reilly), -mealoig=melic (from mel, honey), the pith is like honey; fer or feur, grass; corcuir, crimson or purplish. In some parts of the Highlands the plant is called braban (Stewart.)

Glyceria.-From Greek, $\gamma \lambda \nu \kappa v$ s, sweet, in allusion to the foliage.

G. fluitans-Floating sweet grass. Milsean wisge, millteach uisge, - perhaps from millse, sweetness. Horses, cattle, and swine are fond of this grass, which only grows in watery places. 
Trout (Salmo fario) eat the seeds greedily. The name millteach is frequently applied to grass generally as well as to Triglochin palustre (which see). Feur uisge, water-grass.

Briza.-Quaking-grass. Gaelic and Irish : conan,-conan, a hound, a hero, a rabbit,-may possibly be named after the celebrated "Conan Maol," who was known among the Feine for his thoughtless impetuosity. He is called "Aimlisg na Feinne," the mischief of the Fenians. This grass is also called feur gortach, hungry, starving grass. "A weakness, the result of sudden hunger, said to come on persons during a long journey or in particular places, in consequence of treading on the fairy grass" -(Irish Superstitions). Feur sithein sithe,-literally, a blast of wind; a phantom, a fairy. The oldest authority in which this word sithe occurs is Tirechan's 'Annotations on the Life of St Patrick,' in the Book of Armagh, and is translated "Dei terreni," or gods of the earth. Crith fhèr, quaking-grass. Grigleann (in Breadalbane), that which is in a cluster, a festoon; the Gaelic name given to the constellation Pleïades.

Cynosurus.-Etym. кvẃv, a dog, and ov́pá, a tail.

C. cristatus-Crested dog's-tail. Gaelic: goinear, or goin fheur, and sometimes conan (from coin, dogs, and feur, grass). Irish : feur choinein, dog's grass.

Festuca.-Gaelic: féisd. Irish : féiste. Latin : fastus and festus. French: feste, now fête. English : feast, as applied to grass, good pasture, or food for cattle.

F. ovina-Sheep's fescue-grass. Gaelic and Irish: feur chaorach.

$$
\begin{aligned}
& \text { "Min-fheur chaorach."-M'INTYRE. } \\
& \text { Soft sheep grass. }
\end{aligned}
$$

This grass has fine sweet foliage, well adapted for feeding sheep and for producing good mutton-hence the name. But Sir H. Davy has proved it to be less nutritious than was formerly supposed. Min-fheur (Armstrong), is applied to any soft grass -as Holcus mollis - to a flag, a bulrush; as "min-fheur gun uisge," a bulrush without water (in Job).

Triticum, according to Varro, was so named from the grain being originally ground down. Latin : tritus, occurring only in the ablative (tero). Greek : $\tau \epsilon i \rho \omega$, to rub, bruise, grind.

T. æstivum (and other varieties) - Wheat. Gaelic and Irish : cruithneachd-cruineachd. This name seems to be associated with the Cruithne, a tribe or tribes who, according to tradition, came from Lochlan to Frin, and from thence to Alban, where 
they founded a kingdom which lasted down till the seventh century. Another old name for wheat-breothan, may similarly be connected with another ancient tribe, "Clanna Brcogan. They occupied the territory where Ptolemy in the second century places an offshoot of British Brigantes."-SKENE. Were these tribes so called in consequence of cultivating and using wheat? or was it so called from those tribal names? are questions that are difficult to answer. It seems at least probable that they were among the first cultivators of wheat in Britain and Ireland. Breothan, that which is bruised; the same in meaning as triticum. Other forms occur, as brachtan, ${ }^{1}$ being bruised or ground by hand in the "muileann bràdh," the quern; sometimes spelled breachtan. Mann, wheat, food. Fiormann, -for, genuine, and mann, a name given to a variety called French wheat. Tuireann, perhaps from tuire, good, excellent. The flour of wheat is universally allowed to make the best bread in the world. Romhan, Roman or French wheat; "branks."

T. repens-Couch, twitch. Scotch : dog-grass, quickens, \&c. Gaelic: feur a'-phuint ( $\mathrm{M}^{\prime}$ Kenzie), the grass with points or articulations. Every joint of the root, however small, having the principle of life in it, and throwing out shoots when left in the ground, causing great annoyance to farmers. (From the root punc or pung; Latin, punctum, a point.) Goin-fheur, dogsgrass; or goin, a wound, hurt, twitch. According to Rev. Mr Stewart, Nether Lochaber, this name is also given to Cynosurus. Fiothran, the detestable. It is one of the worst weeds in arable lands on account of the propagating power of the roots. Bruim fheur, flatulent grass. Probably only a term of contempt.

T. junceum-Sea-wheat grass. Gaelic: glàs fheur, the pale green grass; a seaside grass. It helps, with other species, to bind the sand.

Lolium perenne and temulentum - Darnell, rye-grass. Gaelic : breoillean. Irish : breallan (breall or breallach, knotty), from the knotty appearances of the spikes, or from its medicinal virtues in curing glandular diseases. "And being used with quick brimstone and vinegar it dissolveth knots and kernels,

${ }^{1}$ Latin : brace or brance. Gallic, of a- particularly white kind of corn. According to Hardouin, bléblanc Dauphiné, Triticum Hibernum, Linn., var. Granis albis. Lat, sandala.

"Galliæ quoque suum genus farris dedere : quod illie brance vocant apud nos sandalum nitidissimi grani."-PLINY, 18, 7. 
and breaketh those that are hard to be dissolved"-Culpepper. Dithean, darnel; perhaps from dith, want, poverty. It may be so named from its growing on poor sterile soil, which it is said to improve. "They have lately sown ray-grass to improve cold, clayey soil "-Dr PlatT, I677. Roille. Irish : raidhleadh, from raidhe, a ray-hence the old English name ray-grass. French: ivraie, darnel. Welsh : efr-perhaps alterations of the French ivre, drunk. The seeds of darnel, when mixed with meal, cause intoxication, and are believed to produce vertigo in sheep-the disease that maketh them reel; and for this reason the grass is often called sturdan, from sturd,-hence Scotch sturdy grass. Siobhach, from siobhas, rage, fury, madness. "It is a malicious plant of sullen Saturn : as it is not without some vices, so it hath also many virtues"-Culpepper. Cuiseach (M'Alpine), rye-grass. Ruintealas (O'Reilly), the loosening, aperient, or purgative grass-from minnec, grass, and tealach, loosening.

Nardus stricta-Mat-grass, moor-grass. Gaelic: beitean (perhaps from beithe), was refused. Cattle refuse to eat it. It remains in consequence in dense tufts, till it is scorched by early frosts. In this condition it is frequently burned, in order to destroy it. Borrach (in some places), parching. Carran (Stewart), a name given also to Spergula arrensis. To this grass and other rough species, as rushes, sedges, \&c., the name riasg is given.

"Cuiseagan-a's riasg

Chinneas air an t'sliabh." -M'INTyRE.

Aira flexuosa-Waved hair-grass. Gaelic: moin-fheur, peatgrass. It grows generally in peaty soil.

\section{CRYP'TOGAMIA.}

\section{Filices.}

Filices - Ferns. Gaelic : raineach, roineach. Irish : raith, raithne, raithneach; also, reathnach. Welsh: rhedyn. Perhaps formed from reath, a revolution or turning about, or rat, motion, from the circinate evolution of the young fronds-an essential characteristic of ferns.

Polypodium vulgare-Cloch-reathneach (Armstrong), the stone-fern ; cloch, a stone. It is common on stone-walls, stones, and old stems of trees. Ceis-chrànn. Irish : céis chrainn,cis, a tax, tribute, and crànn, a tree, because it draws the substance from the trees; or from the crosier-like development of the fronds, like a shepherd's crook, "cis-cean." Sgiamh na cloch. 
Syreamh means reproach, and sgiamh or sgèimh, beauty, ornament ; "na cloch," of the stones. The second idea seems, at least in modern times, to be more appropriate than the first, especially as the term was applied to the really beautiful oakfern.

"Mu chinneas luibhean 'us an sgìimh."

How the flowers and the ferns grow.

Reidh raineach,- - reidh, smooth, plain. Raineach nan crag, the rock-fern. Mearlag (in Lochaber), perhaps from meàr or meir , a finger, from a fancied resemblance of the pinnules to fingers.

P. Dryopteris-Oak-fern. Gaelic and Irish : sgeamh dharaich (O'Reilly), the oak-fern. No Gaelic name is recorded for the beech-fern ( $P$. Phegopteris).

Blechnum spicant-Hard fern. The only Gaelic name supplied for this fern is "an raineach chruaidh," hard fern. It is impossible to say whether this is a translation or not. Being a conspicuous and well-defined fern, it must have had a Gaelic name.

Cystopteris fragilis-Bladder-fern. Gaelic: friodh raineach, or frioth fhraineach,_- "frioth," small, slender. The tufts are usually under a foot long; stalks very slender.

Polystichum aculeatum, lobatum, and angulare-Gaelic: ıbhig (Rev. A. Stewart), the name by which the shield-ferns are known in the West Highlands. This name may have reference to the medicinal drinks formerly made from the powdered roots being taken in water as a specific for worms (see L. filix-mas), from $i b h$, a drink. French: ivre. Latin : ebrius.

P. Lonchitis-Holly fern. Gaelic: raineach-chuilinn (Stewart), holly fern, known by that name in Lorne; also colg raineach, in Breadalbane and elsewhere. For cuileann and colg, see Ilex aquifolium.

Lastrea Oreopteris-Sweet mountain fern. Gaelic: crimraineach (Stewart). Most likely from creim, a scar, the stalks being covered with brown scarious scales. In some places the name fàile raineach is given, from faile, a scent, a smell. This species may be easily distinguished by the minute glandular dots on the under side of the fronds, from which a fragrant smell is imparted when the plant is bruised.

L. filix-mas-Male fern. Gaelic and Irish: marcraineach, horse-fern. Marc. Welsh : march. Old High German: marah, 
a horse. This fern has been celebrated from time immemorial as a specific for worms; the powdered roots, taken in water, were considered an excellent remedy. Irish : raineach-madra, dog-fern.

L. spinulosa, and the allied species dilatata and Fonisccii, are known by the name raineach nan rodainn, from Latin, rodo. Sanscrit : rad, to break up, split, gnaw, - the rat's fern, in Morven, Mull, and Lewis. "Dr Hooker is mistaken as to the range of this fern, as it is extremely abundant here, at least in the form of dilatata" -(Lewis Correspondent). ${ }^{1}$ The name rat's fern, from its commonness in holes, and the haunts of rats.

Athyrium filix-fœmina-Lady-fern. Gaelic and Irish: raineach Mhuire, Mary's fern,-Muire, the Virgin Mary, Our Lady; frequently occurring in plant-names in all Christian countries.

Asplenium.-From Greek: $a$, privative, and $\sigma \pi \lambda \eta \nu$, the spleen.

A. Trichomanes-Black spleenwort. Gaelic and Irish : dùbh chàsach, dark-stemmed. Lus na seilg, from sealg, the spleen. This plant was formerly held to be a sovereign remedy for all diseases of this organ, and to be so powerful as even to destroy it if employed in excess. Lus a chorrain. Urthàlmhan (O'Reilly), - ìr, green, and talamh, the earth. As dìbh chìsuch is the common name for Trichomanes-probably ir thalmhan was applied to $A$. viride. Failtean fionn, see $A$. capillusVeneris.

A. Ruta-muraria-Rue fern. Gaelic: rue bhallaidh, wall-rue.

A. Adiantum-nigrum-Gaelic: an raineach uàine, the green fern. Irish : craobh mac fiadh (O'Reilly), -craobh, a tree, a plant, and muc fiadh, wild pig or boar.

Scolopendrium vulgare-Hart's-tongue fern. Gaelic : creamh mac fiadh, or in Irish, creamh nam muc fiadh. Wild boar's wort, a name also given to Asparagus.

Pteris aquilina-Common brake. Gaelic: an raineach mhor, the large fern. Raith (see Polypodium). The brake is used for various purposes by the Gaels, such as for thatching cottages;

${ }^{1} \mathrm{My}$ well-informed correspondent also remarks : "I may mention one or two other plants, regarding which Dr Hooker's information is slightly out. His Salix repens is very common here and in Caithness, though absent in at least some parts further south. Utricularia minor can easily be found in quantities near the Butt of Lewis; and Scutellaria minor, which he allows no further than Dumbarton, grows equally far north, although all I am aware of could be covered by a table-cloth. Another interesting plant, Eryngium maritimum, grows in a single sandy bay on our west coast." 
and beds were also made of it. It is esteemed a good remedy for rickets in children, and for curing worms.

Adiantum capillus-Veneris-Maiden-hair fern. Gaelic : failtean fionn (Armstrong), from falt, hair, and fionn, fair, resplendent. This fern is only known in the Highlands by cultivation. This name is frequently given to Trichomanes (dibh chasach) improperly.

Ophioglossum-From Greek : ǒфıs, a serpent, and $\gamma \lambda \omega ́ \sigma \sigma \eta, a$ tongue. The little fertile stalk springing straight out of the grass may not inaptly be compared to a snake's tongue.

O. vulgatum-Adder's tongue. Lus na nathraith (M'Kenzie), the serpent's weed. Teanga $a$ ' nathrach, the adder's tongue. Welsh: tafad $y$ neidr, adder's tongue. In the Western Highlands, beasan or feasan (Stewart).

Osmunda-Osmunder, in Northern mythology, was one of the sons of Thor (Gaelic: Tordan, the thunderer, the Jove of the Celts ; os in Celtic, over, above, upon, and munata, a champion, in Irish), - said to have received the name on account of its potential qualities in medicine.

o. regalis - Royal fern. Gaelic: raineach rioghail, kingly fern; righ raineach, royal fern. In Ireland it is called bogonion.

Botrychium lunaria-Moonwort. Gaelic : luan lus, moonwort. Welsh : y lleîadlys,-lleuad, moon. "Luan, the moon, seems a contraction of luath-an, the swift planet"-ARMSTRONG. But rather from Sanscrit : luach, light. Latin : luna. French : lune. Déur lus and dealt lus (Stewart),- -déur, a tear, a drop of any fluid, and dealt, dew. This plant was held in superstitious reverence among Celtic and other nations. Horses were said to lose their shoes where it grew. "On Sliabh Riabhach Mountain no horse can keep its shoes; and to this day it is said that on Lord Dunsany's Irish property there is a field where it is supposed all live stock lose their nails if pastured there." "A Limerick story refers to a man in Clonmel jail who could open all the locks by means of this plant.". The same old superstition still lingers in the Highlands-

There is an herb, some say whose virtue's such

It in the pasture, only with a touch,

Unshoes the new-shod steed.

"On White-Down, in Devonshire, near Tiverton, there was found thirty horse-shoes pulled off from the feet of the Earl of Essex, his horses being there drawn up into a body, many of 
them being but newly shod, and no reason known, which caused much admiration; and the herb described usually grows upon heaths."-CULPEPPER.

Ferns frequently formed components in charms.

"Faigh naoi gasan rainaich

Air an gearradh, le tuaigh,

A's tri chnaimhean seann-duine

Air an tarruinn à uaigh," \&c.-M 'INTYRE.

Get nine branches of ferns

Cut with an axe,

And three old man's bones

Pulled from the grave.

"Fern seeds were looked upon as magical, and must be gathered on Midsummer eve."-Scottish and Irish Superstition.

\section{LYCOPODIACEE.}

Lycopodium, from $\lambda \hat{\text { ḱ }}$ s, a wolf, and $\pi \circ \hat{s}$, a foot, from a fancied resemblance to a wolf's foot.

L. Selago-Fir club-moss. Gaelic: garbhag an sleibhe, the rough one of the hill. "The Highlanders make use of this plant instead of alum to fix the colours in dying. They also take an infusion of it as an emetic and cathartic; but it operates violently, and, unless taken in a small dose, brings on giddiness and convulsions."-Lightfoot. According to De Thèis, "Selago" is derived from the Celtic, sel (sealladh), sight, and jach (ioc). Greek: iacıs, a remedy, being useful for complaints in the eyes.

Badge of Clan $\mathrm{M}^{\prime}$ Rae.

L. clavatum, annotinum, and the rest of this family are called lus bhalgaire, the fox-weed.

\section{EquiseTACEE.}

Equisetum, from equns, a horse, and seta, hair, in allusion to the fine hair-like branches of the species. Those plants of this order growing in watery places are called in Gaelic and Irish, clois, clo-uisge, the names given to fuviatile, palustre, ramosum; and those flourishing in drier places, earbuill-each, horse-tail. Clois seems a contraction of clo-uisge (O'Reilly), -clo, a nail-pen or peg, perhaps suggested by the appearance of the fruiting stems, and uisge, water.

E. hyemale-Dutch rushes, shave-grass. Gaelic: a bhiorag, -bior, a pointed small stick, anything sharp or prickly. Or water (sce Appendix). This species was at one time extensively 
used for polishing wood and metal, a quality arising from the cuticle abounding in siliceous cells-hence the use made of the plant for scouring pewter and wooden things in the kitchen. A large quantity used to be imported from Holland, hence the name "Dutch rushes." Irish: gadhar, from gad, a withe, a twig. Liobhag, from liobh, smooth, polish. It grows in marshy places and standing water. Cuiridin (O'Reilly), because growing on marshy ground.

\section{BRYACEÆ.}

Gaelic and Irish : coinneach, caoineach, from caoin, soft, lowly, \&c. The principal economic use of moss to the ancient Gaels was in making bed-stuffs, just as the Laplanders use it to this day.

" Trì coilceadha na Feinne, bàrr gheal chrann, coinneach, 'us ùr luachair."

The three Fenian bed-stuffs-fresh tree-tops, moss, and fresh rushes.

Welsh : muerug, moss.

Sphagnum-Bog-moss. Gaelic: mointeach liath (moin, peat, and liath, grey). From its roots and decayed stalks peat is formed. Fionnlach, from fionn, white. It covers wide patches of bog, and when full grown it is sometimes almost white; occasionally the plant has a reddish hue (coinneach dhearg, red moss). Martin refers to it in his 'Western Islands :' "When they are in any way fatigued by travel or otherways, they fail not to bathe their feet in warm water wherein red moss has been boiled, and rub them with it on going to bed." This seems to be the only moss having a specific name in Gaelic, the rest going by the generic term coinneach.

"Còinich uine mu 'n iomall,

A's imadach seòrsa."-M'INTYRE.

Green moss around the edges,

Many are the kinds.

\section{MarchantiaceÆ ANd Lichenes.}

Marchantia polymorpha-Liverwort. Gaelic: lus an àinean, the liverwort. Irish : ciiisle aibheach. Welsh: llysiar afu-afu, the liver. (Names derived from its medicinal effects on the liver.) Irish : duilleog na criithneachta, the leaf of (many) shapes or forms. Criith, form, shape, synonymous with Greek "polymorpha."

Peltidea canina-The dog-lichen. Gaelic: lus ghonaich (from goin, wound; goineach, agonising). This plant was formerly used for curing distemper and hydrophobia in dogs. The name "gearan, the herb dog's-ear," is given in the dictionaries. 
Probably this name was applied to this plant, meaning a complaint, a groan. Welsh : gerain, to squeak, to cry.

Lecanora.-Etymology of this word uncertain (in Celtic, lech or leac, means a stone, a flag). Greek: $\lambda i \theta$ os.

L. tartarea-Cudbear. Gaelic and Irish : corcar or corcur, meaning purple, crimson. This lichen was extensively used to dye purple and crimson. It is first dried in the sun, then pulverised and steeped, commonly in urine, and the vessel made air-tight. In this state it is suffered to remain for three weeks, when it is fit to be boiled in the yarn which it is to colour. In many Highland districts many of the peasants get their living by scraping off this lichen with an iron hoop, and sending it to the Glasgow market. M'Codrum alludes to the value of this and the next lichen in his line

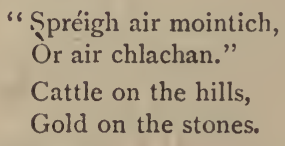

Parmelia saxatilis and omphalodes-Stone and heath parmelia. Gaelic and Irish : crotal. These lichens are much used in the Highlands for dyeing a reddish brown colour, prepared like tartarea. And so much did the Highlanders believe in the virtues of crotal that, when they were to start on a journey, they sprinkled it on their hose, as they thought it saved their feet from getting inflamed during the journey. Welsh : cen dì, black head, applied to the species Omphalodes.

Sticta pulmonacea (Pulmonaria of Lightfoot) - Lungwort lichen. Scotch: hazelraue. Gaelic and Irish: crotal coille ("coille" of the wood), upon the trunks of trees in shady woods. It was used among Celtic tribes as a cure for lung diseases, and is still used by Highland old women in their ointments and potions.

According to Shaw, the term grim was applied as a general term for lichens growing on stones. Martin, in his description of his journey to Skye, refers to the superstition "that the natives observe the decrease of the moon for scraping the scurf from the stones." The two useful lichens, corcur and crotal, gave rise to the suggestive proverb-

"Is fhearr a' chlach gharbh air am faighear rud-eigin, na 'chlach mhin air nach faighear dad idir."

Better the rough stone that yields something, than the smooth stone that yields nothing. 


\section{FUNGI.}

Agaricus-'The mushroom. Irish and Gaelic dictionaries give agairg for mushroom. Welsh : cullod.

A. campestris-Balg bhuachail (balg is an ancient Celtic word, and in most languages has the same signification-viz., a bag, wallet, pock, \&c. (Greek, $\beta$ o $\gamma$ vs; Latin, bulga; Sax. belge; Ger. bálg), buachail, a shepherd). Balg losgainn (losgann a frog, and in some places bàlg bhuachair,-buachar, dung), Leirin sugach. In Aberfeldy A. campestris is called bonaid bhuidhli smachain (Dr M'Millan).

Boletus bovinus-Brown boletus. Gaelic and Irish : bonaid an losgainn, the toad's bonnet; and also applied to other species of this genus.

Tuber cibarium-Truffle. Ballan losgaim, Dr M'Millan, from ball, a ball, a tuber. These are subterraneous ball-like bodies, something like potatoes, found in beech-woods in Glen Lyon; and probably applied to other species as well.

Lycoperdon giganteum-The large fuz-ball or devil's snuffbox. Gaelic and Irish : beac, beacan, from beach, a bee. This mushroom or puff-ball was used formerly (and is yet) for smothering bees; it grows to a large size, sometimes even two or three feet in circumference. Trioman (O'Reilly).

I. gemmatum-The puff-ball, fuz-ball. Gaelic and Irish: caochag, from caoch (Latin, cacus), blind, empty, blasting. It is a common idea that its dusty spores cause blindness. Bàlg smiid, the smoke-bag; bàlg séididh, the puff-bag. Bìlg peiteach bocan, or bochdan-bearrach (bochdan, a hobgoblin, a sprite, and bearr, brief, short), and bonaid an losgainn, are frequently applied to all the mushrooms, puff-balls, and the whole family of the larger fungi.

Polyporus.-The various forms of cork - like fungi growing on trees are called caise (Irish), meaning cheese, and in Gaelic spuing or (Irish) spuinc, sponge, from their porous spongy character.

P. fomentarius and betulinus-Soft tinder. Gaelic: cailleach spuinge, the spongy old woman,-a corruption of the Irish caisleach spuine, soft, cheese-like sponge. It is much used still by Highland shepherds for making amadou or tinder, and for sharpening razors.

Mucedo-Moulds. Gaelic : cloimh liath, grey down. Mildew, milcheo. 
Mushrooms bear a conspicuous part in Celtic mythology from their connection with the fairies, - they formed the tables for their merry feasts. Fairy rings (Marasmius oreades, other species of Agarici) were unaccountable to our Celtic ancestors save by the agency of supernatural beings.

ALGE.

The generic names assigned to sea-weeds in Gaelic are: feamainn (feam, a tail); trailleach (M'Alpine), (from tràigh, shore, sands); barra-rochd (barr, a crop), roc. Greek : ¡ó $\dot{\xi}$. French : rocke, a rock. Welsh: gweymon, sea-weed. French : varec, from Sanscrit, bharc, through the Danish vrag. All the olive-coloured sea-weeds go by the general name feamainn buidhe; the dark-green, feamainn dubh; and the red, feamainn derg.

Fucus vesiculosus - Sea-ware, kelp-ware, black tang, ladywrack. Gaelic : propach, sometimes prablach, tangled; in sone places gròbach, gròb, to dig, to grub.

This fucus forms a considerable part of the winter supply of food for cattle, sheep, and deer. In the Hebrides cheeses are dried without salt, but are covered with the ashes of this plant, which abounds in salt. It was also used as a medicinal charm. "If, after a fever, one chanced to be taken ill of a stitch, they (the inhabitants of Jura) take a quantity of ladyzorack and red fog and boil them in water; the patients sit upon the vessel and receive the fume, which by experience they find effectual against the distemper." - Martin's "Western Isles.'

F. nodosus-Knobbed sea-weed. Gaelic: feamainn bholgainn, builgach,-bolg, builg, a sack, a bag, from the vesicles that serve to buoy up the plant amidst the waves. Feamuinn buidhe, the yellow wrack. It is of an olive-green colour; the receptacles are yellow.

F. serratus-Serrated sea-weed. Gaelic: feamainn dubh, black wrack. Aon chasach, one-stemmed, applies to this plant when single in growth.

F. canaliculatus-Channelled fucus. Gaelic: feamainn chirean (cir, a comb). This plant is a favourite food for cattle, and farmers give it to counteract the injurious effects of sapless food, such as old straw and hay.

Laminaria digitata-Sea-girdles, tangle. Gaelic and Irish: stamh, slàt-mhàra, sea-wand. Duidhean, the stem, and liaghag 
or leathagan, barr stamh, and bragair, names given to the broad leaves on the top. Doire (in Skye), tangle. Though not so much used for food as formerly, it is still chewed by the Highlanders when tobacco becomes scarce. It was thought to be an effectual remedy against scorbutic and glandular diseases, even long before it was known to contain iodine. "A rod about four, six, or eight feet long, having at the end a blade slit into seven or eight pieces, and about a foot and a half long. I had an account of a young man who lost his appetite and had taken pills to no purpose, and being advised to boil the blade of the Alga, and drink the infusion boiled with butter, was restored to his former state of health "-MarTin's 'Western Isles.' By far the most important use to which this plant and the other fuci have been put was the formation of kelp; much employment and profit were derived from its manufacture : e.g., in 1812 , in the island of North Uist, the clear profits from the proceeds of kelp amounted to $£ 14,000$; but the alteration of the law regarding the duty on barilla reduced the value to almost a profitless remuneration of only $£ 3500$.

L. saccharina-Sweet tangle, sea-belt. Gaelic: smeartan (smear, greasy). The Rev. Mr M'Phail gives this name to "one of the red sea-weeds." Other correspondents give it to this plant.

I. bulbosa-Sea furbelows, bulbous-rooted tangle. Gaelic: sgrothach. This name is doubtful (sgroth, pimples, postules).

Alaria esculenta-Badderlocks, hen-ware (which may be a contraction of honey-ware, the name by which it is known in the Orkney Islands). Gaelic: mircean (one correspondent gives this name to "a red sea-weed"), seemingly the same as the Norse name Mária kjerne,-Mári, Mary, and kjerne is our word kernel, and has a like meaning. In Gaelic and Irish dictionaries, muirirean (Armstrong), muiririn (O'Reilly), "a species of edible alga, with long stalks and long narrow leaves"-Shaw. In some parts of Ireland, Dr Drummond says, it is called murlins-probably a corruption of muiririn, muirichlinn, muirlinn (M'Alpine), (from muir, mara, the sea). It is known in some parts of Ireland by the name sparain or sporain, purses, because the pinnated leaflets are thought to resemble the Highlander's sporan. Gruaigean (in Skye).

Rhodymenia palmata-Dulse. Gaelic and Irish : duiliasg, from duille, a leaf, and uisge, water-the water-leaf. The Highlanders and Irish still use duiliasg, and consider it wholesome 
when eaten fresh. Before tobacco became common, they used to prepare dulse by first washing it in fresh water, then drying it in the sun: it was then rolled up fit for chewing. It was also used medicinally to promote perspiration. Fithreach, dulse. Duiliasg stuimhe (staimh, Laminaria digitata). It grows frequently on the stems of that fucus. Duiliasg chlaiche-i.e., on the stones, the stone dulse. Duileasg is also given to Laurentia finnatifida, formerly eaten under the name of pepper dulse.

Porphyra laciniata-Laver, sloke. Gaelic and Irish : sloucan, slochdan, from sloc, a pool or slake. Slabhcean (in Lewis), slàbhagan (Shaw). Lightfoot mentions that "the inhabitants of the Western Islands gather it in the month of March, and after pounding and stewing it with a little water, eat it with pepper, vinegar, and butter; others stew it with leeks ancl onions.

Ulva latissima-Green ulva. Gaelic : glasag, also applied to other edible sea-weeds. In some places in the Western Highlands the names given to laver are also given to this plant. Glasag, from glàs, blue, or green.

Palmella montana (Ag.) - Lightfoot describes, in his 'Flora Scotica,' a plant which he calls Ulia montana, and gives it the Gaelic name duileasg nam beann-i.e., the mountain dulse. This plant is Gloeocapsa magma (Kutzing). Protococcus magma (Brebisson, Alg. Fallais). Sorospora montana (Hassall). Lightfoot was doubtless indebted to Martin (whose 'Western Isles' furnished him with many of his useful notes on the uses of plants among the Highlanders) for the information respecting such a plant. Martin describes it thus: "There is seen about the houses of Bernera, for the space of a mile, a soft substance resembling the sea-plant called slake [meaning here Ulva latissima], and grows very thick among the grass ; the natives say it is the product of a dry hot soil ; it grows likewise on the tops of several hills in the island of Harris." "It abounds in all mountainous regions as a spreading crustaceous thing on damp rocks, usually blackish-looking; but where it is thin the purplish nucleus shines through, giving it a brighter aspect."-Roy.

Chondrus crispus-Irish moss, known in the Western Highlands by the Irish name an carraceen, as the chief supply used to come from Carrageen in Ireland. At one time it was in much. repute, for from it was manufactured a gelatinous easily digested food for invalids, which used to sell for $2 \mathrm{~s}$. Gd. per lb. Mathair 
an duileasg, the mother of the dulse, as if the dulse had sprung from it.

Corallina officinalis.-Gaelic: coireall (M'Alpine). Isatin : corallium, coral. Linean. It was used as a vermifuge.

Polysiphonia fastigiata. A tuft of this sea-weed was sent to me with the Gaelic name Fraoch màra, sea-heather, written thereon.

Hemanthalia lorea. - The cup-shaped frond from which the long thongs spring is called aiomlach, or iomleach (iomleag, the navel), from the resemblance of the cup-shaped disc to the navel. Dr Neill mentions that in the north of Scotland a kind of sauce for fish or fowl, resembling ketchup, is made from the cup-like or fungus-like fronds of this sea-weed.

Halydris siliquosa.-Gaelic: roineach mhàra, the sea-fern. (In the Isle of Skye.)

Chorda filum-Sea-laces. In Shetland, Lucky Minny's lines ; Ayrshire, dead men's ropes. Gaelic: gille mu leann (or mu lion),-gille, a young man, a servant; lion, a net. Lightfoot mentions that the stalks acquire such toughness as to be used for fishing lines, and they were probably also used in the manufacture of nets. At all events it is a great obstacle when trawling with nets, as it forms extensive sea-meadows of long cords floating in every direction. In some parts langadair is given to a "sea-weed, by far the longest one." This one is frequently from twenty to forty feet in length.

Sargassum vulgare (or bacciferum)-Sea-grapes. Gaelic: tiirusgar (sometimes written trusgar, from trus, gather), from tiirus, a journey. This weed is frequently washed by the Gulf Stream across the great Atlantic, with beans, nuts, and seeds, and cast upon the western shores. These are carefully gathered, preserved, and often worn as charms. They are called uibhean sithein, fairy eggs, and it is believed that they will ward off evil-disposed fairies. The nuts are called cnothan-spuinge, and most frequently are Dolichas urens and Mimosa scandens. To Callithamnion Plocamium, \&c., and various small red sea-weeds, such as adorn ladies' albums, the Gaelic name smocan is applied.

Confervæ, such as Enteromorpha and Cladophora. Gaelic and Irish: lianach or linnearach (linne, a pool). Martin describes a plant under the name of linarich - "a very thin, small, green plant, about eight, ten, or twelve inches in length ; it grows on stones, shells, and on the bare sands. This plant is applied plasterwise to the forehead and temples to procure sleep for 
such as have a fever, and they say it is effectual for the purpose." -Martin's 'Hebrides.' Barraig uaine, the green scum on stagnant water. Feuruisge, water-grass. Lochan. Griobharsgaich, the green scum on water.

"Tha uisge sruth na dige

$\mathrm{Na}$ shrùthladh dùbh gun sioladh

Le barraig uaine, liògh ghlas,

Gu mi bhlasda grannd,

Féur lochan is tachair

An cinn an duileag bhàite."-M'INTYRE.

The water in its channel flows,

A dirty stagnant stream,

And algæ green, like filthy cream,

Its surface only shows.

With water-grass, a choking mass,

The water-lily grows. 


\section{A P P E N D I X.}

\section{ADDITIONAL GAELIC NAMES.}

These names were either unintentionally omitted, or did not come under my observation until too late for insertion in their proper botanical order.

Airgiod luachra (Spirea ulmaria)-Meadow-sweet, meaning the silvery rush. Airgiod. Latin : argentum.

Amharag (Sinapis arvensis) - Cherlock. From the root amh, raw or pungent, and probably corrupted into "Marag" bluidhe (page 7); also in Cochlearia officinalis. A'maraich (page 5), for amharaich, from the same root, on account of the pungent taste of both plants.

Barr a-bhrigean (Potentilla anserina)-Silverweed.

Bath ros (Rosmarinus officinalis) - Rosemary. From bàth, the sea; and ròs, a rose.

Bearnan bearnach (Taraxacum dens-leonis)-Dandelion.

Bearnan bealtine (Caltha palustris)-Marsh-marigold.

Billeog an spuinc (Tussilago farfara)-Coltsfoot (page 4I).

Biodh an 't sionaidh (Sedum anglicum). (Sionaidh, a prince, a lord, chief; biodh, food.) From the name it is evident that the plant was formerly eaten, and considered a delicacy.

Bior ros (Nymphaea)-Water-lily. Bior, or its aspirated form bhir or bhior, meaning water; in Arabic, bir; Hebrew, beer. From this root comes the name bhiorag, a water-plant (Equisetum hyemale, page 96), and such place and river names as ver in Inver, her in Hereford, and the river Wear in Durham.

Blath nam bodaigh (Papaver)-Poppy, meaning the rustic's flower.

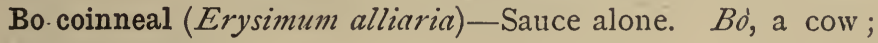
coinneal, a candle.

Buidhechan-bo-bleacht (Primula veris) - Cowslip. The milkcow's daisies (page 57 ).

Cal Phadruigh (Saxifraga umbrosa)-London pride; Peter's kale.

Cannach (Myrica gale)-Bog-myrtle. (This name must not be 
confounded with canach, the bog-cotton.) It means any fragrant shrub, pretty, beautiful, mild, soft.

Caorag leana (Lychnis flos-cuculi)-Ragged robin. Caorag, a spark; and leana, a marsh.

Caor con (Viburnum opulus)-Dogberry. Caor, a berry; con, dog.

Cerrucan (Daucus carota and Sium sisarum)-Skirrets. Name applied to the roots of these and the next plant.

Curran earraich (Potentilla anserina) - Silver-weed; wild skirret (page 19).

\section{"Mil fo thalamh, currain Earraich." \\ Unclerground honey, spring carrots.}

"Exceptional luxuries. The spring carrot is the root of the silver-weed."--Sheriff Nicolson.

Coirean coilleach (Lychnis diurna) (page 8).

Collaidin ban (Papaver)-White poppy (page 4).

Corran lin (Spergula arvensis) - Spurrey.

Cuirinin (Nymphaa)-Water-lily.

Daileag (Phonix dactylifera)-The date-tree.

Dearag thalmhainn (Fumaria officinalis)-Fumitory. From dearg, red; thalamh, earth, ground.

Dearcan dubh (Ribes nigrum)-Black currants. For dearc see page 45 .

Deochdan dearg (Trifolium pratense)-Red clover.

Driuch na muine (Drosera rotundifolia)-Sun-dew. Driuch, dew ; and na muine of the hill.

Dun, lus (Scrophularia nodosa) - Figwort, the high plant. According to Bede dìn means a height in the ancient British language; hence the terminations of names of towns, don and ton.

Eabh (Populus tremula)-Aspen. The Gaelic for Eve.

Eanach (Nardus stricta).

Easdradh (Filices)-Ferns.

Eidheann mu chrann (Hedera helix) - The ivy (page 28).

" Gach fiodh 's a' choille

Ach eidheann mu chrann a's fiodhagach."

Every tree in the wood

Except $i z y$ and bird-cherry tree.

Feathlog fa chrann (Lonicera pericly'menuml) (page 34).

Fib (Vaccinium vitis idaca)-Whortleberry.

Fineal ghreugach (Trigonella)-Greek fennel.

Fiodh almug (Santalum album)-Sandal-wood. 
"Agus mar an ceudna loingneas Hiram a ghiulain or o Ophir, agus. ro mhoran do fhiodh almuig." -(STUART) I Kings x. II:"

The navy of Hiram brought in from Ophir gold and great plenty of Almug trees.

Fionnach (Nardus stricta)-From fionn, white.

Fiuran and giuran (Heracleum spondylium)-Cow-parsnip.

Fofannan min (Sonchus oleraceus) - Sow-thistle. For fofannan, see fothannan (page 38).

Forr dris (Rubus rubiginosa)-Sweet-briar.

Fuaim an t' Siorraigh (Fumaria efficinalis) - Fumitory. Fuaim, sound; an t' Siorraigh, of the sheriff! Probably only a humorous play on the words "fumaria officinalis." ...

Furran (Quercus robur) - The oak.

Gairleach collaid (Erysimum alliaria)-Jack by the hedge; meaning hedge garlic.

Gairteog (Pyrus malıs) - Crab-apple. From garg, sour, bitter.

Gall pheasair (Lupinus)-Lupin (see page 16).

Gall uinnseann (Pyrus aria)-Quickbeam tree.

Gearr bochdan (Cakile maritima)-Sea gilly-flower.

Glaodhran (Oxalis and Rhinanthus crista-galli)_Meaning a "rattle." Dictionaries give this name to wood-sorrel; in Breadalbane it is applied generally to the yellow rattle.

Glocan (Prunus padus)-Bird-cherry. Glocan or glacan, a prong or fork.

Goirgin garaidh (Allium ursinum)-Garlic.

Goirmin searradh (Viola tricolor)-Pansy; heart's-ease.

Gran arcain (Ranunculus ficaria)-Lesser celandine. Arc, a cork, from its cork-like roots.

Leamhnach (Potentilla tormentilla) - Common tormentil. Name in Gaelic, meaning "tormenting," from which "leannartach" probably is a corruption (see page I9).

$\left.\begin{array}{l}\text { Leacan, } \\ \text { Loan cat }\end{array}\right\}$ (Cotyledon umbilicus)-Navel-wort.

Lochal mothair (Veronica beciabunga)-Brook-lime.

Lusra na geire-boirnigh (Arbutus uva-ursi)-Red bear berry, the plant of bitterness. Geire, bitterness; and boirnigh, feminine. See "meacan easa fiorine."

Lus na meala mor (Malva sylvestris) - The common mallow.

Lus mor. Also applied to Verbascum thapsus, Mullein, as well as to the foxglove (Digitalis).

Lus ros (Geranium Robertianum)-Herb Robert ; crane's-bill ; the rose-wort. 
Lus an lonaidh (Angelica sylvestris)-Wood angelica. Lonaidh is the piston or handle of the churn. The umbelliferous flower has much the appearance of that implement. The common name in Breadalbane (see page $3 \mathrm{r}$ ).

Lus an t' seann duine-The old man's plant. Name given in sonie places to "southernwood," Artemisia abrotanum.

Lus na seabhag-Hawkweed.

Meacan easa beanine (Pconia) - Female pæony.

Meacan easa fiorine (Pconia)-Male pæony. Old botanists used to distinguish between two varieties of this plant, and named them male and female. This was a mere fanciful distinction, and had no reference to the real functions of the stamens and pistils of plants; but yet there existed a vague idea, from time immemorial, that fecundation was in some degree analogous to sexual relationship, as in animals - hence such allusions as "Tarbh, coille," "Dair na coille" (see page 68).

Meilise (Sisymbrium officinale) - Hedge mustard.

Neandog chaoch (Lamium)-Dead nettle; blind nettle.

Onn. Some authorities give this name to Ulex europau, as well as to Euonymus. Welsh, chuyn-hence Scotch and English zhin.

Pea:air tuilbh (Orobus tuberosus) - Bitter vetch.

Ponair churraigh (Menyanthes)-Marsh trefoil, meaning the marsh-bean, bog-bean.

Pis phreachain (Vicia satiz $a)-\mathrm{Pis}=$ peas. Preachan, a ravenous bird.

Raibhe (Raphanus)-Radish.

Ramasg-Applied to various species of Fuci, from ram, a branch, an oar = oar-weed.

$\left.\begin{array}{l}\text { Reagha maighe, } \\ \text { Reagaim and raema }\end{array}\right\}$ (Sanicula europceus)-Wood-sanicle.

Reilige, reilteag (Geranium Robertianum)-From reil or rcul, a star.

Rian roighe (Gcranium Robertianum)-C'rane's-bill.

Ros mall (Althea rosea)-Hollyhock.

Rotheach tragha (Crambe maritima)-Seakale.

Searbhan muic (Cichorium endiva)-Endive.

Seircean mor (Arctium lappa)-Burdock.

Seud (Hypericum).

Sibhin (Scirpus lacustris)-Bulrush.

Siode, lus (Lychnis flos-cuculi)-Ragged Robin; meaning the silk-weed, from its silken petals.

Son duileag (Lapsanc communis) - Nipple-wort. Son, good; ¿luileagr, a leaf. 
Spog na cubhaig (Viola triolor) - Pansy, heart's-ease ; meaning the cuckoo's claw.

Spriunan (Ribes nigrum and rubrum)-Currants.

Straif (Prunus spinosa) - Sloe.

Sreang thrian (Ononis arvensis)-Rest-harrow.

Staoin (Nepeta glechoma)-Also applied to ground-ivy in some places, as well as to juniper.

Subh nam ban sithe (Rubus saxatilis)--Stone-bramble; the fairy-woman's strawberry.

Toir-pin (Sempervivum tectorum)-House-leek; probably the same as tir-pin (see page 27).

Traithnin (Geum urbanum)-Geum.

Treabhach (Barbarca v'ulgaris) - Winter cress: Treabh, a tribe, a village.

Truim crann (Sambucus niger) - Elder, corruption from arum (see page 34 ).

Tuile thalmhainn (Ranunculus bulbosus) - Tuile, a water-course.

Tuimpe-Turnip.

\section{NOTES.}

Page 6.

Nasturtium officinalis-Water-cress. A curious old superstition respecting the power of this plant as a charm to facilitate milk-stealing was common in Scotland and Ireland. "Not long ago, an old woman was found, on a May morning, at a springwell cutting the tops of water-cresses with a pair of scissors, muttering strange words, and the names of certain persons who had cows, also the words, "S' liomsa leath do choud sa" (half thine is mine). She repeated these words as often as she cut a sprig, which personated the individual she intended to rob of his milk and cream." "Some women make use of the root of groundsel as an amulet against such charms, by putting it amongst the cream." - MARTIN. Among the poorer classes, water-cress formed a most important auxiliary to their ordinary food. "If they found a plot of water-cresses or Shamrock, there they flocked as to a feast for the time."-Spencer.

\section{Page 8.}

Drosera rotundifolia_-Sun-dew. Lus na farnaich. "Earnach" was the name given to a distemper among cattle, caused, 
it is supposed, by eating a poisonous herb. Some say the sundew-others, again, aver the sun-dew was an effectual remedy. This plant was much employed among Celtic tribes for dyeing the hair.

\section{Page 8.}

Saponaria. The quotation from Pliny may be thus translated: "Soap is good-that invention of the Gauls-for reddening the hair, out of grease and ash."

\section{Page 9.}

Linum usitatissimum (Lion).

"Mèirle salainn 's mèirle frois, Mèirl' o nach fhaigh anam clos;

Gus an teid an t-iasg air tir,

Cha 'n fhaigh mèirleach an lin clos."

"This illustrates the great value attached to salt and lint, especially among a fishing population, at a time when the duty on salt was excessive, and lint was cultivated in the Hebrides."Sheriff Nicolson.

\section{Page ro.}

Hypericum. Martin evidently refers to this plant, and calls it "Fuga dcemonum." "John Morrison, who lives in Bernera (Harris), wears the plant called "Seud" in the neck of his coat to prevent his seeing of visions, and says he never saw any since he first carried that plant about with him." Children have a saying when they meet this plant-

"Luibh Cholum Chille, gun sireadh gun iarraidh,

'Sa dheòin Dia, cha bhàsaich mi nochd."

St Columbus-wort, unsought, unasked, and, please God, I won't die to-night.

\section{Page I 2.}

Shamrock-Wood-sorrel and white clover. The shamrock is said to be worn by the Irish mpon the anniversary of St Patrick for the following reason: When the Saint preached the Gospel to the pagan Irish, he illustrated the doctrine of the 'Trinity by showing them a trefoil, which was ever afterwards worn upon the Saint's anniversary. "Between May-day and harvest, butter, new cheese, and curds and shamrock, are the fool of the meaner sort all this season."-Piers's 'West Meath.'

\section{Page I 3 .}

Gaelic Alphabet. Antecedent to the use of the present alphabet, the ancient Celts wrote on the barks of trees. The 
writing on the bark of trees they called oglumim, and sometimes trees, feadha, and the present alphabet litri or letters.

" Cormac Casil cona churu,

Leir Mumu, cor mela ;

Tragaid im righ Ratha Bicli,

Na Litri is na Feadha."

Cormac of Cashel with his companions

Munster is his, may he long enjoy ;

Around the King of Raith Bicli are cultivated

The LETTERS and the TreFs.

The "letters" here signify, of course, our present Gaelic alphabet and writings; but the "trees" can only signify the oghuin, letters, which were named after trees indigenous to the country."-Prof. O'CuRry.

\section{Page 16.}

Orobus tuberosus (Corra meille, M'Alpin, and cairmeal, Armstrong) - Bitter vetch - and sometimes called "wild liquorice"-seems to be the same name as the French "caramel," burnt sugar; and according to Webster, Latin, "canna mellis," or sugar-cane. The fermented liquor that was formerly made from it, called cairm or cuirm, seems to be the same as the "courmi" which Dioscorides says the old Britons drank. 'The root was pounded and infused, and yeast added. It was either drunk by itself, or mixed with their ale-a liquor held in high estimation before the days of whisky; hence, the word "cuirm" signifies a feast. That their drinking gatherings cannot have had the demoralising tendencies which might be expected, is evident, as they were taken as typical of spiritual communion. In the Litany of "Aengus Céilé Dé," dating about the year 798, we have a poem ascribed to St Brigid, now preserved in the Burgundian Library, Brussels.

"Ropadh maith lem corm-lina mor, Do righ na righ,

kopadh maith lem muinnter nimhe

Acca hol tre bithe shir."

I should like a great lake of ale

For the King of kings;

I should like the family of heaven

To be drinking it through time eternal.

To prevent the inebriating effects of ale, "the natives of Mull are very careful to chew a piece of "charmel" root, finding it to be aromatic-especially when they intend to have a drinking- 
bout ; for they say this in some measure prevents drunkenness." -Martin's 'Western Isles.'

Trees, Thorns. A superstition was common among the Celtic races, that for every tree cut down in any district, one of the inhabitants in that district would die that year. Many ancient forts, and the thorns which surrounded them, were preserved by the veneration, or rather dread, with which the thorns were held ; hence, perhaps, the name sgitheach, sgith (anciently), fear ; hence also, droighionn (druidh), enchantment, witchcraft.

\section{Page 20.}

Rubus fruticosus -(Smearagan $)$ Blackberries. It was and is, I believe, still a common belief in the Highlands that each blackberry contains a poisonous worm. Another popular belief is-kept up probably to prevent children eating them when unripe-that the fairies defiled them at Michaelmas and Halloween.

\section{Page 24.}

Pyrus aucuparia-(Craobh ihaoran) Mountain-ash. The Highlanders have long believed that good or bad luck is connected with various trees. The caoran or fuinnseach coille (the wood enchantress) was considered by them as the most propitious of trees; hence, it was planted near every dwellinghouse, and even far up in the mountain-glens, still marking the spot of the old shielings. "And in fishing-boats as are rigged with sails, a piece of the tree was fastened to the haul-yard, and held as an indispensable necessity." "Cattle diseases were supposed to have been induced by fairies, or by witchcraft. It is a common belief to bind unto a cow's tail a small piece of mountain-ash, as a charm against witchcraft."-MaRTin. And when malt did not yield its due proportion of spirits, this was a sovereign remedy. In addition to its other virtues, its fruit was supposed to cause longevity. In the Dean of Lismore's Book there occurs a very old poem, ascribed to Caoch O'Cluain (Blind O'Cloan); he described the rowan-tree thus-

"Caorthainn do bhi air Loch Maoibl do chimid an traigh do dheas, Gach a ré 'us gach a mios toradh abuich do bhi air.

Seasamh bha an caora sin, fa millise no mil a bhlàth, Do chumadh a caoran dearg fear gun bhiadh gu ceann naoi tràth, Bleadhna air shaoghal gach fir do chuir sin is sgeul dearbh."

A rowan-tree stood on Loch Mai,

We see its shore there to the south;

Every quarter, every month, It bore its fair, well-ripened fruit; 
There stood the tree alone, erect, Its fruit than honey sweeter far, That precious fruit so richly red Did suffice for a man's nine meals; A year it adderl to man's life."

-Translated by Dr M'LAuchian.

\section{Page 26.}

Ribes grossularia. The prickles of the gooseberry-bush were used as charms for the cure of warts and the stye. A weddingring laid over the wart, and pricked through the ring with a gooseberry thorn, will remove the wart. Ten gooseberry thorns are plucked to cure the stye-nine are pointed at the part affected, and the tenth thrown over the left shoulder.

\section{Page $3 \mathbf{I}$.}

Meum athamanticum - Muilceann. The Inverness local name for this plant, "Bricin," is probably named after St Bricin, who flourished about the year 637. He had a great establishment at Tuaim Drecain. His reputation as a saint and "ollamh," or doctor, extended far and wide; to him Cennfaeladh, the learned, was carried to be cured after the battle of Magh Rath. He had three schools for philosophy, classics, and law. It seems very strange, however, that this local name should be confined to Inverness, and be unknown in Ireland, where St Bricin was residing.

\section{Page 32.}

Pastinaca sativa-(Curran geal) The white wild carrot, parsnip. The natives of Harris make use of the seeds of the wild white carrot, instead of hops, for brewing their beer, and they say it answers the purpose sufficiently well, and gives the drink a good relish besides.

"There is a large root growing amongst the rocks of this island-the natives call it the 'Curran petris,' the rock.carrot - of a whitish colour, and upwards of two feet in length, where the ground is deep, and in shape and size like a large carrot." - Martin.

Daucus carota-Curran buidhe. "The women present the men (on St Michaelmas Day) with a pair of fine garters, of divers colours, and they give them likewise a quantity of wild carrots."-MARTIN.

\section{Page 34 .}

Sambucus niger-(Druman $)$ The elder. "The common people [of the Highlands] keep as a great secret in curing wounds the 
leaves of the elder, which they have gathered the first day of April, for the purpose of disappointing the charms of witches. They affix them to their doors and windows."-C. DE IRYNGIN, at the Camp of Athole, June $30,165 \mathrm{r}$.

Misletoe and ivy were credited with similar powers. "The inhabitants cut withies of misletoe and ivy, make circles of them, keep them all the year, and pretend to cure hectic and other troubles by them."--See Appendix to Pennant's 'Tour.'

"The misletoe," says Valancey, in his "Grammar of the Irish Language,' "was sacred to the Druids, because not only its berries, but its leaves also, grew in clusters of three united to one stock."

\section{Page 38.}

Carduus benedictus-Fothannan beannuichte, though applied to "Marianus," is probably "Centaurea benedictus," and was so called from the many medicinal virtues it was thought to possess. It is a native of Spain and the Levant.

C. heterophyllus-Melancholy thistle. Was said to be the badge of James I. of Scotland. A most appropriate badge; but yet it had no connection with the unfortunate and melancholy history of the Stuarts, but was derived from the belief that a decoction of this plant was a sovereign remedy for madness, which, in older times, was called "melancholy."

The plant generally selected to represent the Scotch heraldic thistle is Onopordon acanthium, the cotton thistle, and, strange to say, it does not grow wild in Scotland. Achaius, king of Scotland (in the latter part of the eighth century), is said to have been the first to have adopted the thistle for his device. Favine says Achaius assumed the thistle in combination with the rue: the thistle, because it will not endure handling; and the rue, because it would drive away serpents by its smell, and cure their poisonous bites. The thistle was not received into the national arms before the fifteenth century.

Quercus robur-Darach. The age of the oak-tree was a matter of much curiosity to the old Gaels :-

"Tri aois coin, aois eich ;

Trì aois eich, aois duine ;

Trì aois duine, aois féidh ;

Trì aois féidh, aois fìrein ;

Trì aois firein, aois craoibh-dharaich."

Thrice dog's age, age of horse.

Thrice horse's age, age of man ;

Thrice man's age, age of deer ;

Thrice deer's age, age of eagle ;

Thrice eagle's age, age of oak. 
"The natives of Tiree preserve their yeast by an oaken wyth, which they twist and put into it, and for future use keep it in barley straw."-MARTin.

\section{Page 43 .}

Chrysanthemum leucanthemum - Ox eye daisy, called in Gaelic "Breinean brothach." Breinean or brainean also means a king; Welsh, brenkin. The word is now obsolete in the Highlands. The plant was a remedy for the king's-evil.

Page 44 .

Achillea millefolium-Earr thalmhainn. The yarrow, cut by moonlight by a young woman, with a black-handled knife, and certain mystic words, similar to the following, pronounced-

"Good-morrow, good-morrow, fair yarrow, And thrice good-morrow to thee ;

Cume, tell me before to-morrow,

Who my true love shall be."

The yarrow is brought home, put into the right stocking, and placed under the pillow, and the mystic dream is expected; but if she opens her lips after she has pulled the yarrow, the charm is broken. Allusion is made to this superstition in a pretty song quoted in the 'Beauties of Highland Poetry,' p. 381 , beginning-

"Gu'n dh'eirich mi moch, air madainn an dé,

'S ghearr mi'n earr-thalmhainn, do bhri mo sgéil ;

An dùil gu'm faicinn-sa rùin mo chléibh ;

Ochòin ! gu'm facas, 's a cùl rium féin."

I rose yesterday morning early,

And cut the yarrow according to my skill,

Expecting to see the beloved of my heart.

Alas : I saw him-but his back was towards me.

The superstitious customs described in Burns's "Halloween" were common among the Celtic races, and are more common on the western side of Scotland, from Galloway to Argyle, in consequence of that district having been occupied for centuries by the Dalriade Gaels.

\section{Page 47.}

Fraxinus excelsior-Craobh uinnseann (the ash-tree) was a most potent charm for cures of diseases of men and animalse.g., murrain in cattle, caused, it was supposed, by being stung in the mouth, or by being bitten by the larva of some moth. "Bore a hole in an ash-tree, and plug up the caterpillar in it, the leaves of that ash are a sure specific for that disease." 
Martin adds, "the chief remedies were 'charms' for the cure of their diseases."

\section{Page $5 \mathrm{I}$.}

Verbena officinalis-Trombhod. Borlase, in his 'Antiquities of Cornwall,' speaking of the Druids, says: "They were excessively fond of the vervain; they used it in casting lots and foretelling events. It was gathered at the rising of the dogstar."

Page 68.

Corylus avellana-Càlltuinn. Còl, càl, in Welsh, signifies loss, also hazel-wood. The Welsh have a custom of presenting a forsaken lover with a stick of hazel, probably in allusion to the double meaning of the word.

$$
\text { Page } 78 \text {. }
$$

Allium porrum - "Bugha." The explanation given by Shaw that this was a name for leek seemed improbable, especially as it was a favourite comparison to the eye "when it is blue or dark." Turning to a passage describing Cormac Mac Airt, I found-

$$
\text { "Cosmail ri bugha a shùili," }
$$

which Professor O'Curry renders-

"His eyes were like slaes,"-

a far more appropriate comparison. Narcissus, Lus a chrìmchinn (the bent head), suggests the beautiful lines of Herrick-

"When a daffodill I see

Hanging its head t'wards me,

Guesse I may what I must be :

First, I shall decline my head :

Secondly, I shall be dead ;

Lastly, safely burried."

\section{A. ursinum -Creamh.}

\section{Page 79 .}

" 'Is leigheas air gach timn

Creamh 'us im a' Mhaigh."

Garlic and May butter

Are remedies for every illness.

"Its medicinal virtues were well known; but like many other plants once valued and used by our ancestors, it is now quite superseded by pills and doses prepared by licensed practitioners."-Sheriff Nicolson. 
Page 8I.

Potamogeton natans - Duiliasg na h'aibhne. The broad-leaved pondweed is used in connection with a curious superstition in some parts of Scotland, notably in the West Highlands. "It is gathered in small bundles in summer and autumn, where it is found to be plentiful, and kept until New Year's Day (old style); it is then put for a time into a tub or other dish of hot water, and the infusion is mixed with the first drink given to milch cows on New-Year's Day morning. This is supposed to keep the cows from witchcraft and the evil eye for the remainder of the year! It is also supposed to increase the yield of milk." - Rev. A. Stewart, Nether Lochaber.

\section{Page 87 .}

Arundo phragmites-Cruisgiornach (cruisigh, in Irish, music, song). Reeds were said by the Greeks to have tended to subjugate nations by furnishing arrows for war, to soften their manners by means of music, and to lighten their understanding by supplying implements for writing. These modes of employment mark three different stages of civilisation. The great reed mace (Typha latifolia) cuigeal nam bàn sithe, is usually represented by painters in the hand of our Lord, as supposed to be the reed with which $\mathrm{He}$ was smitten by the Roman soldiers, and on which the sponge filled with vinegar was reached to Him.

Oats-Coirc. Martin mentions an ancient custom observed on the $2 \mathrm{~d}$ of February. The mistress and servant of each family take a sheaf of oats and dress it in woman's apparel, put it in a large basket, with a wooden club by it, and this they call Briid's bed. They cry three times Briid is come, and welcome. This they do before going to bed, and when they rise in the morning they look at the ashes for the impress of Briid's club there ; if seen, a prosperous year will follow.

Algæ-Feamainn. The inhabitants of the Isle of Lewis had an ancient custom of sacrificing to a sea-god called "Shony" at Hallowtide. The inhabitants round the island came to the church of St Mulvay, each person having provisions with him. One of their number was selected to wade into the sea up to the middle, and carrying a cup of ale in his hand, standing still in that position, crying out with a loud voice, "Shony, I give you this cup of ale, hoping you will be so kind as to send us plenty of sea-ware for enriching our ground the ensuing year." And he then threw the cup into the sea. This was performed 
in the night-time; they afterwards returned to spend the night in dancing and singing.

Shony (Sjoni), the Scandinavian Neptune. This offering was a relic of pagan worship introduced into the Western Isles by the Norwegians when they conquered and ruled over these islands centuries ago (see footnote, p. 40).

K'EOGH's Works. - The Rev. John K'Eogh wrote a work on the plants of Ireland, 'Botanalogica Universalis Hibernia,' and another on the animals, 'Zoologica Medicinalis Hibernia,' about the year I739, giving the Irish names as pronounced by the peasantry at that period. They are now rare works, and are of no value save for the names, for they contain no information except the supposed medicinal virtues of the plants and animals given in them.

All creatures, from the biggest mammal to the meanest worm, and all plants, were supposed to have some potent charm or virtue to cure disease. A large number of K'Eogh's prescriptions are compounds of the most disgusting ingredients. We can only now smile at the credulity that would lead any one to imagine that by merely looking at the yellow-hammer (Emberiza citrinella) "by any one who has the jaundice, the person is cured, but the bird will die." Or that "the eyes drawn entire out of the head of a hare taken in March, and dried with pepper, and worn by women, will facilitate childbirth."

He gives this singular cure for the jaundice: "A live moth, laid on the navel till it dies, is an excellent remedy! Nine grains of wheat taken up by a flea, are esteemed good to cure a chincough - that insect is banished and destroyed by elder leaves, flowers of pennyroyal, rue, mint, and fleabane, celandine, arsmart, mustard, brambles, lupin, and fern-root." For worms: "Take purslane seeds, coralina, and St John's-wort, of each an equal part; boil them in spring water. Or take of the powders of hiera picra (Picris hieracioides), of the seeds of the bitter apple, of each one dram, mixed with the oil of rue and savin, spread on leather, and apply it to the navel; this is an approved remedy." Epilepsy-"The flesh of the moor hen, with rosemary, lemons, lavender, and juniper berries, will cure it." And for children - "Take a whelp (cullane), a black sucking puppy (but a bitch whelp for a girl), strangle it, open it, and take out the gall, and give it to the child, and it will cure the falling-sickness." One more example will sufficiently illustrate the value of K'Eogh's books. "'Usnea capitis humani, or the 
moss growing on a skull that is exposed to the air, is a very good astringent, and stops bleeding if applied to the parts, or even held in the hand."

Ollamh. This was the highest degree, in the ancient Gaelic: system of learning, and before universities were established, included the study of law, medicine, poetry, classics, \&c. A succession of such an order of literati, the Beatons, existed in Mull from time immemorial, until after the middle of last century. Their writings were all in Gaelic, to the amount of a large chestful. Dr Smith says that the remains of this treasure were bought as a literary curiosity for the library of the Duke of Chandos, and perished in the wreck of that nobleman's fortune. If this lost treasure could be recovered, we would have valuable material for a more complete collection of Gaelic names of plants, and information as to the uses to which they were applied, than we now possess.

Medicinal Plants. - The common belief that a plant grew not far from the locality where the disease prevailed, that would cure that disease, led to many experiments which ultimately resulted in finding out the undoubted virtues of many plants ; but wholesale methods were frequently adopted by gathering all the herbs, or as many as possible, in that particular district and making them into a bath.

At the battle of "Magh Tuireadh," we are informed " that the chief physician prepared a healing bath or fountain with the essences of the principal herbs and plants of Erinn, gathered chiefly in Lus-Magh, or the Plain of Herbs; and on this bath they continued to pronounce incantations during the battle. Such of the men as happened to be wounded in the fight were immediately plunged into the bath, and they were instantly refreshed and made whole, so that they were able to return and fight against the enemy again and again."-Prof. O'CURRY.

Incantations with Plants.-Cures by incantations were most common. A large number of plants were thus employed. When John Roy Stewart sprained his ankle, when hiding after the battle of Culloden, he said :-

"Ni mi'n ubhaidh rinn Peadar do Phàl,

'S a lùighean air fàs leum bruaich, Seachd paidir n' ainm Sagairt a's Pàp

Ga chuir ris na phlàsel mu'n cuairt." 
I'll make the incantation that Peter made for Paul,

With the herbs that grew on the ground :

Seven paternosters in the name of priest and pope, Applied like a plaster around.

"And if the dislocated joints did not at once jump into their proper places during the recitation, the practitioner never failed to augur favourably of the comfort to the patient. There were similar incantations for all the ills that flesh is heir to: the toothache could not withstand the potency of Highland magic; dysentery, gout, \&c., had all their appropriate remedies in the never-failing incantations." $-M$ 'KenzIE. See "Beauties of Highland Poetry,' p. 268, where several of the "orations" repeated as incantations are given.

Plants and Fairy Superstitions. - A large number of plant-names in Gaelic have reference to fairy influence. At births many ceremonies were used to baffle the fairy influence over the child (see page 57), otherwise it would be carried off to fairyland. The belief in fairies as well as most of these superstitions, is traceable to the early ages of the British Druids, on whose practices they are founded. The foxglove (Meuran sithe), odhran, the cow-parsnip, and copagach, the docken, were credited with great power in breaking the fairy spell; on the other hand, some plants were supposed to facilitate the fairy spell, and would cause the individual to be fairy "struck" or "buillite." The water-lily was supposed to possess this power, hence its names, Buillite, and Rabhagach, meaning beware, warning. Rushes found a place in fairy mythology: Schonus nigricans (Seimhean) furnished the shaft of the elf arrows, which were tipped with white flint, and bathed in the dew that lies on the hemlock.

NetTLES - "They also used the roots of nettles and the roots of reeds as cures for coughs." In some parts of Ireland there is a custom on May eve and May day amongst the children, especially the girls, of running amuck with branches of nettles, stinging every one they meet. They had also a belief that steel made hot and dipped in nettle-juice made it flexible. Camden says "that the Romans cultivated nettles when in Britain in order to rub their benumbed limbs with them, on account of the intense cold they suffered when in Britain." A remedy worse than the disease. 


\section{N D E X.}

\section{GAELIC NAMES.}

Abhal, adhul, 23.

Ahhran donog, 82.

Agairg, 99

Aiglineann thalmhainn, 54 .

Aigheannach, 38 .

Aillean, 42.

Ailm, 65 .

Aingealag, 31.

Ainean, lus an, 97 .

Airc, aircean, 67.

Airmeirg, 35 .

Airneag, 17.

Aiteil, aitiol, 74 .

Allas Mhuire, 11.

Alne, 77.

Amon, 18.

A oin, 83.

Aon chàsach, 100.

Aonsgoth, 4.

Apricoe, 17.

Asair, 62 .

Asparag, 80.

Athair liath, 53.

Athair thalmhainn, 44.

Athan, 41.

Badan measgan, 56 .

Bàinne bo bhuie, 57 .

Bàinne (lus a bbaine), 56 .

Bainne gamhnach, 34

Bainne ghabhair, 50.

Bainne muic, 36 .

Bairghin, 2.

Baladh chnis, 35.

Bàlg bhuachail, 99.

Bàlg losgain, 99 .

Balg bhuachair, 99 .

Bà'g smuid, 99.

Bàlg seididh, 99.

Ballan losgainn, 99.

Bàn, crann, 11.

Barbrag, 3.

Bar-gue, 14

Bar-dearg, 58.

Bàrr braonan-nan-con, 19.

Barr cluigeannach, 44 .

Barr a inhilltich, 81 .

Barra mhislean, 15 .

Barrag ruadh, 4.

Barr-stamh, 100.

Barrag uaine, 104

Bearnan bride, 37 .

Beacan, 99.

\author{
Bearnan bearnach (Appendix). \\ Bealuidh, bealaidh, 14 \\ Bealaidh frangach, 14. \\ Bealaidh sasunach, 14. \\ Bealuidh (calg), 80. \\ Beatha, or beithe, 68 . \\ Beathag, lns, 55 . \\ Beathe beag, 69. \\ Beathe carraigeach, 69 . \\ Beathe cluàsach, 69 . \\ Beathe, dubh casach, 69 . \\ Beathe dubhach, 69 . \\ Beathe nam measa, 67. \\ Beilbheag, 4. \\ Beitean, 92. \\ Bhracadail, Ius, 63 . \\ Biodh nan eoinean, 13. \\ Biodh an sionaich (Appen. \\ dix)
}

Biatas, biatus, 55,59 .

Bile buidhe, 42 .

Bile cuige (Appendix).

Bileach choigreach, 42 .

Bileach losgain, 22.

Bileanach, bilearach, 104.

Billeog math, 36.

Billeog son (Appendix).

Bilur, 61.

Biodh a leithid, 8.

Biolair, 6, 119 .

Biolair tràgha, 5 .

Biolair mhuine, 49.

Biolair ghriaghain, 6 .

Bior leacain, 74 .

Biorag, 96

Bior na bride, 37 .

Biotas, betis, 59

Blioch, bliochan, 80 .

Blioch fochain, 37 .

Bliosan, 39.

Bloinigean gàraidh, 59.

Bo coinneal (Appendix).

$B$, chdan bearrach, 99 .

Bocsa, 63.

Bo dhearc, 46.

Bodan, 82, 87 .

Bodan dubh, 82 .

Bodan coille, 29

Bodan measgan, 56.

Bodan na cloigin, 50.

Bodach gorm, 36

Bodach na claiginn, 50 .

Bodach dủbh, 59.
Bofulan ban, 40

Bog lus, 36, 56.

Bog bhuine, 82.

Bog luachair, 85.

Big ghioghan, 36 .

Bog uisge, 76 .

Boinne fala, 61 .

Bolg lins, 36, 55 .

Bo'gan beic, 51.

Bonaid an losgain, 99

Borrach, \&7, 92

Borraist, 55 .

Burramotor, 40.

Braonan fraoch, 19.

Braonan bachlag. 19, 30 .

Braonan buachail, 30 .

Braban, 89.

Breallan leana, 26.

Breoillean, 91.

Breinean brothach, 43, 115.

Breothan, 91.

Bricin dubh, 31, 113.

Brisgean, 19, 106.

Brisglan, 19

Bròbh, 85.

Bı òighleag, 46.

Bròighleag nan con, 45

Brium fheur, 91.

Brng na cubhaig, $S, 56,57,80$

Bròg braidhe, 83 .

Bròn (craobh bhròin), 73.

Brurn, 14.

Bru-chorach, 84

Buadha, lus nain, 31.

Buadhlan buidhe, 42 .

Buadh ghallan, 42 .

Bualan, am, 41.

Buafannan, 40 .

Buafannan buidhe, 43.

Buafaunan bản, 40 .

Buafannan liatb, 40 .

Buafannan na h' easgaran, 41.

Bugha, 78, 116

Buidhe mor, 7 .

Buidhe bealtainn (Appendix).

Buidheag, 2, 42

Buidheag an arbhair, 43

Buidhe na ningean, 63 .

Buillite, 4, 12".

Bulastair, 17.

Buine, 29.

Bùnglàs, 89.

Buntata, 49 . 
Bunsag, 71.

Buramaide, 40.

Burban, 40.

Buth a muc, 80 .

Caba deasain, 36 .

Cabhan abhain, 4.

Cabros, 9.

Caineal, 60.

Caineab, 64

Caineab uisge, 44

Cairmeal, 16, 111.

Caisleach spuinc, 99.

Cairteal, 52

Caitean, 66.

Caitheainh, lus, 35 .

Caithne, 45 .

Cal na màra, 5

Cal colbhairt, 6 .

Cal cearsleach, 6.

Cal gruidhean, 6 .

Cal Phadruig (Appendix).

Calltuinn, 68, 116.

Calg bhealaidh, 80 .

Calg bhrudhan, 80 .

Calameilt, 52

Caman scarraigh, 4

Cam-bhil, 43.

Camomhil, 43.

Camomhil fiahhain, 43

Canach, 86

Canal, 60.

Cannach (Appendix).

Caoch nan cearc, 49

Caod aslachan Cholum chille 11.

Caogma, 29.

Caoimin, 50.

Caoirin leana, 35 .

Caolach, lns, 9.

Caol fail, 64.

Caol miosachan, 9.

Caoran, 24, 112

Caoran staoin, 74 .

Caor bad miann, 20.

Caor thalmhainn, 30 .

Canr fionnag, 62.

Caorag leana (Appendix).

Carbhainn, 30.

Carbhaidh, 30.

Carraceen, 102

Carran, 5, 9, 92.

Carrait, 32 .

Cartal, 52.

Carthan curaigh, 35.

Carthan arraigh, 35.

Cas fa chrann, 34 .

Cas an uain, 15

Castearban nam mue, 37 .

Cás maidhiche, 15.

Casgair, 63.

Cassachdaighe, 41 .

Cat luibl, 40.

Catog, 20

Cathair thalmhainn, 4

Caubsadan, 53 .

Ccnamh briste, lus nan, 56 .

Cearban, 2

Cearban feoir, 2

Ceanabhan beag, 55 .

Ceann ruadh, 4.

Ceathramadh - luain - caorach, 60 .

Ceadharlach, 48 .

Ceud bhileach, 48.

Ceir-iocan, 34.

Ceis chrainn, 92.

Ceosan, 38

Céusaidh, lus chraun, 61.
Cholum-cille lus, 11, 57.

Chraois, lus a, 29

Chrom chinn, lus a, 77.

Chridh, lus a, 55

Chuimein, lns Mhic, 30.

Cinb cheann dưbh, 85 .

Ciochan nan cailleachean

marbha, 51.

Cirean coileach, 8

Cirean, feamainn, 100 .

Clabrus, 27.

Clachan ghadhair, 75 .

Clamhainin lin, 49.

Cloch bhriseach, 27.

Cloch reathneach, 92 .

Clo-uisge, 96

Cloimh liath, 99.

Cluas, lus nan, 27

Cluas an fhéidh, 38 .

Cl tas chaoin, 82 .

Cluas luch, 9,37

Cluas liath, 37,41 .

Cluain Jin, 9

Cluaran, 38

Cluaran deilgneach, 38

Cluaran leaua, 38.

Cluaran oir, 39.

Cluaran liath, 42.

Cnapan, lus nan, 50.

Cnapan dubh, 39

Cnành lus, 4\%.

Cnaib uisge, 44.

Cno thalmhainn, 30 .

Cno ghreugach, 18.

Cnothan spuing, 103.

Codalian, 4.

Cogall, 9

Coindid, coinne, cainnen, 79.

Coin ros, 21.

Coin droighionn, 21.

Coin fheur, 90

Coin bhil, 28.

Coin bhaisene, 28.

Coinneach, 97.

Coinneach dhearg, 97.

Coirearan muic, 30.

Coireiman, 33.

Coirnel, 28

Coir, lus a, 33.

Coire, 88, 117.

Coirc dủblı, 89

Coireall, 102.

Colag, 6.

Colluinn, 68 .

Columeille, lus, 11, 57 .

Colg bhealaidh, 80 .

Coman mionla, 43.

Con, cona, 86 .

Conaire,

Conan, 90.

Conasg, 14.

Contran, 31

Copag, 61

Copag shraide, 62 .

Copag tuaithil, 38.

Copan an driuclid, 22.

Corcach, 64.

Corcar, 98.

Corcan coille, 8

Corn caisiol, 27.

Corrach shod, 2

Corra meille, 16, 111.

Cor-chopaig.

Cosadh dubhach, 32 .

Còs uisge, 33

Cosga na fola, 44.

Costag, 32 .

Costag a bhaile gheamhraidh,

33.
Còta preasach nighean an righ, 22.

Cotharach; 56.

Crann lus, 41.

Craobh mac fiadh, 95 .

Cré, lus, 50.

Creachlach deárg, 12.

Creamh, 42, 48, 79, 116.

Creamh gharaidh, 79 .

Creainh nan crag, 79.

Creamh mac fiadh, 80 .

Creamh nam Muic fiadh, 80 , 93.

Crios chu-chulainn, 18.

Critheann, 70.

Crò, crodh, cròch, 77.

Crob priachain, 12

Crotal, 98.

Crotal coille, 98.

Cromlus, 4.

Cruach Phadruigh, 58.

Cruaidh lus, 44.

Crùbh eoin, 14.

Crùth leomhainn, 22.

Cruach luachair, 85.

Cruba-leisin, 3.

Cruban, lus, 47.

Cruban na saona, 20.

Cruithneach, 90 .

Crumagan, 31 .

Cruach Phadruigh, 58.

Cuach Phadruigh, 58 .

Crnisgiornach, 87, 117 .

Cucumhar, 64 .

Cuig bhileach, 19.

Cuig mhear Mhuire, 19.

Cuig bhileach uisge, 19 .

Cuige, Bile (Appendix)

Cuigeal an losgain, 75 .

Cuigeal nam bàn sith, 8 ?

Cnilc fheur, 88.

Cuile, 85.

Cuilc mhilis, 82

Cuile chrann, 82 .

Cuileann, 46.

Cuilean tràgha, 29.

Cuinnse, 24.

Cuineag mhighe, 31 .

Cuirteagan, 23.

Cuir dris, 21.

Cuiseach, 92.

Cuiseag bhuidhe, 42 .

Cularan, 57, 62, 63 .

Cunach, 49.

Cunical Mhuire, 49.

Cuphair, 73.

Curach na cubhaig, 8, 39.

Curach whanaich, 3.

Curran, 32.

Curran earraich, 108.

Curran geal, 32, 113.

Curran buidhe, 32,113

Cuiridin bàn, 32 .

Cuiseag, 42.

Curcais, 85, 86.

Cuthaigh, 82 .

Cutharlan, 30, 78, 82 .

Da-bhileach, 76 .

Dail chuach, 7 .

Daimisin, 17.

Darach, 66

Darach sior-uaine, 67 .

Dealt ruadh, 8 .

Dealt lus, 95 .

Deandag, 64 .

Dearc, lus nan, 45.

Dearc frangach, 26.

Dearc roide, 46 . 
Dearean fithich, 45.

Dearcan dubh, 106.

Dearna Mhuire, 22

Deathach thalmhainn, 4.

Deideag, 59.

Deilgneach, preas, 3 .

Deolag, 34

Deoghlag, 34.

Deodha, 49.

Detheogha, 49 .

Deur lus, 95 .

Dile, 32.

Dithean, 42, 92 .

Dithean, oir, 42

Dobhar, lus, 6 . .

Doire, 100.

Donn, lus 51.

Dreas, dris, 21.

Dreas muine, 21.

Dreas smear, 21.

Dreas cubhraidl, 21.

Dreimire buidhe, 48.

Dreimire muire, 48

Droighionn, dubh, 17.

Droighionn, geal, 22.

Uroman, 34

Drumain, 34

Druichdin mona, 8 .

Druidh lus, 33.

Dubhan nan caora, 44.

Dublian ceann chosach, 55 .

Dubhannidh, 55 .

Dubh casach, 94 .

Duileag bhaite, 3

Duileag bhaite bhuidhe, 3 .

Duileag bàn, 4 .

Duileag son, mhàith, 37 .

Duileag Bhrighid, 37.

Duileag bhraghad, 37.

Duileag na cruithneachta, 97.

Duileag na h'aibhne, 81,117 .

Duileasg 101

Duileasg staimh, 102.

Duileasg claiche, 102.

Duileasg nam beann, 102 .

Duilliur-feithlean, 34.

Duilliur spuing, 41 .

Duil mhial, 48 .

Dur, drù, 66 .

Dur lns, 6

Dur-fheur-fairge, 88.

Dun lus, 106.

Eadhadh, 70.

Eela bhi, 10.

Eala bhuidhe, 10.

Eallan, lus an, 12.

Eanach, 16.

Earbull righ, 12.

Earbull each, 96.

Earr dhreas, 21.

Earr thalmhainn, 44, 115

Easbilig, lus an, 32

Easbuig bàn, 43.

Easbuig Speain, 43.

Ebersluigh, 53.

Eidheann, 28

Eidheann mu chrann, 106.

Eidheann thalmhainn, 54 .

Eigheann, 28.

Eitheann, 28.

Eil druichd, 8.

Eitheach, 67.

Elebor, 3.

Elebor geal, 76 .

Elefleog, 60 .

Ellea, 42

Enach ghàraidh, 37 .

Eo, 75 .
Eorna, 89.

Faibhile, 67.

Fail chuach, 7 .

Fàiltean fiònn, 95.

Fanaisge, 8.

Falcaire, 58

Falluing Mhuire, 22.

Faracli dubh, 51 .

Farusgag, 39 .

Fathan, 41.

Faithleadgh, 28.

Faithlah, 28.

Fead, 83.

Feada coille, 13 .

Feleastar, 77.

Fealla bog, 29 .

Feallair, 29

Feamainn, 25, 100, 117.

Feamainn bholgainn, 100 .

Feamainn buidhe, 100 .

Feamaiun duth, 100 .

Feamainn dearg, 100 .

Feamainn cirean, 100.

Feandag, 61.

Fearan, 79 .

Fearban, 2.

Fearn, 68 .

Fearnaich lus na, 8, 119.

Fearra-dhris, 21.

Fearsaideag, 6 .

Feith, feithlog, fethlen, 34 .

Feireag, foireag, eireag, 20 .

Fearau curraidh, 54 .

Feoras, 13.

Feur uisge, 90, 104

Feur gortach, 90.

Feur sithein, 90.

Feur choinein, 90

Feur chaorach, 90.

Feur phuint, 91.

Flogair, lus an, 61

Fhograidh, lus an, 3.

Fiadh roidea, 5 .

Fiadhain, eraobh, 34.

Fiacal leomhaiun, 37 .

Fiatghal, 15

Fige, fighis, 65 .

Fineal-chumhthra, 30 .

Fineal sraide, 31

Fineal Mhuire, 6 .

Finemhain, 71 .

Fiod theine, 73.

Fiod sheudar, 73 .

Fiodhag, 18

Fiona, crann, 12.

Fionnach, 107.

Fionnsgoth, 28

Fionnan geal, 28.

Fionnag, lus na, 62 .

Fionnlach, 97

Fioran, 87 .

Fiorthan, 87 .

Fiormann, 91

Fir chrann, 11.

Fiteag chàm, 87.

Fithreach, 112.

Fiuran, 107.

Fleann nisge, 2.

Flige, 9

Fliodh, 9

Fliodh buidhe, 9 .

Fliodh mòr, 31.

Fliodh bhalla, 34

Fochas, 10.

Foghnan, fothannan, 38 .

Foghnan beannuichte, 38, 114

Foinnearnh lus, 63 .

Fola, lus na 44.
Folachdan, 31.

Follasgain, 2

Fonndall, 38.

Fothannan beannuichte, 38 , 314.

Fothròs, 4.

Fotı111, 51.

Fraing, lus, 43.

Fraoch, 44, 45.

Fraoch ruinnse, 44.

Fraoch frangach, 44.

Fraoch bhadain, 45 .

Fraoch dearrasain, 45 .

Fraoch mara, 103.

Fraochan, 45.

Fualactar, 30.

Fualachdtar, 50.

Fuath muje, 80 .

Fuath gorm, 49.

Fuath mhadbairh, 3 .

Fuile thalmhainn, 2

Fuinseag coille, $24,44$.

Fuinnseann, 47 .

Fuinnseach, 25.

Fuinnseagal, 25 .

Gabhan, gafan, 49 .

Gachar, 82.

Gainnisg, 86.

Gair cean, ?

Gairleach collaid (A ppendix).

Gairbhin creugach, 8.

Gairgean creugach, 8, 110 .

Gairgean, 79 .

Gairleag, 79 .

Gairleag callaid (Appendix)

Gairleag Mhuire, 79

Galluran, 31.

Gall pheasair, 16, 107.

Gall chno, 14.

Gall sheileach, 71 .

Gall seileasdar, 86 .

Gall uinseann, 107

Gallan mòr, 41.

Gallan greannchair, 41

Gaoicin euthigh. 82

Garbhag an t' sleibhe, 95.

Garbhag garaidh, 53.

Garbh, lus, 34

Garbliraitheach, 6 .

Gàth, 28.

Gath dubh, 55 .

Gath buidhe, 5,5 .

Gàth mor, 55 .

Geald ruidhe, 8.

Geal sheileach, 71 .

Gealag lair, 77.

Geamn chno, 69

Geamn chno fiadhain, 69 .

Geanais, 17.

Geur-bhileach, 22.

Geur dhearc, 45

Geur neimh, 63.

Gille guirmein, 36 .

Gille mu lion, 103.

Giolceach sleibhe, 14.

Giubhas, 72.

Giubhas geal, 72 .

Giubhas sasunach, 73.

Giubhas Lochlanneach, 72 .

Giuhhas uaine, 73.

Giuran, 107.

Ghlinne, lus, 63.

Glan ruis, 50.

Glas, lus, 5.

Glas fheur, 91.

Glasag, 102.

Glas leun, 2.

Glas lann. 27. 
Glasair coille, 55 .

Gleoran, 6.

Gloiris, 27.

Gluineach lus an, 61 .

Gluineach uisge, 61 .

Gluineach dearg, 61 .

Gluineach bèg, 61 .

Gluineach dubh, 61 .

Gluineach mòr, 61.

Gluineach tèth, 61 .

Gna-ghorm, lus, 12.

Gnàbh, luibh, 40

Gobhal luachair, 85 .

Goin fheur, 90, 91.

Goirteag, 23.

Gorman, 39.

Gorman searraigh (Appendix).

Gorm dheare, 21.

Gorm liath, 41.

Gooneleg (Cornish), 45.

Graban, 40.

Grabhan dubh, 54.

Grabhan bàn, 54 .

Grabhan nan clach, 26.

Grainnseag, 45.

Grainnseav dubh, 45 .

Grain aigein, 2.

Gràn dubh, lus na, 30 .

Gràn lachan, 82.

Gràn ubhal, 25.

Greaban, 18.

Greim an Diabhail, 36.

Grian ròs, 7

Grigleaun, 90

Griobharsgaich, 104.

Grioloigin, 31.

Grobais, 10

Grolla, Iusan, 50.

Groseag, 26.

Gruadg Mhuire, 2.

Grunnasg, 41.

Gugan, 42.

Guis, 34 .

Gunnachan sputachain, 32 .

Guirmean, 5 .

Huath, 23.

Iadh lus, 48 .

Iadh shlat, 23, 34 .

Iadh shlat thalmhainn, 54 .

Ibhig, 93.

Iallain, 28

Inite, luibh, 36 .

Ionntag, 64

Ionntag bhàn, 54 .

Ionntag mharbha, 54 .

Ionntag dherrg, 54 .

Ionutag ghreugach, 14.

Isop, 54.

Iteodha, 29.

Inbhar, iuthar, 74.

Iubhar thalmhainn, 74

Iubhar nan craig, 74 .

I ubhar beinne, 74 .

Iabhras, 60 .

Laoibhrail, 60 .

Lach cheann ruadh, 4.

Lachan, 87.

Lachan nan damh, 84.

Laireag, 73

Lamhan càt leacain, 27.

Langa, 45.

Langadair, 103.

Laoch, lus nan, 26.

Laogh, lus nan, 27

Lroibheach, luibh, 9.

Lasair leana, 2.
Leac, lus an, 50.

Leadan, liodan an fhucadair, 36

Leadan liosda, 38.

Leamhad, 10.

Leamhneach (Appendix).

Leainhan, 65.

Leamhan bog, 68

Leanartach, 19,107 .

Leanna, lus an, 65 .

Learmann, 81.

Lear uinnean, 80 .

Leasaich, lus an, 35 .

Leathach bhuidhe, 22

Leicis, 78 .

Leigis, 78 .

Leolaicheann, 16

Leum a chrann, 34 .

Leusaidh, lus an, 35, 63.

Lia, 42.

Liathan, 42.

Liatus, 36 .

Liach laghor, 4.

Liach roda, 81.

Liach Brighide, 81 .

Liath, lns, 39, 53.

Liath gòrul, craobh, 46.

Liath-lus-roid, 40

Lili, lilidh, 78 .

Lili bhuidhe an uisge, 4 .

Lili na gleann, 78 .

Lili an lòn, 78 .

Limoin, erann, 24.

Linnearach, 103.

Lin radhare, 50 .

Liobhag, 81, 97.

Liobhan, 65 .

Lion, 9, 110.

Liton a bhean sith, 9 .

Lion na h'aibhne, 2.

Lionn, luibh, 65 .

Liugair, luibh an, 31

Liagaire, luibh an, 31.

Lnchal, 49.

Lochan, plur an, 44, 104.

Lothal, 49, 53 .

Luachar, 83.

Luachar bòg, 83.

Luachar coille, 84.

Luan lus, 95.

Luibh laoibheach, 9.

Luis, 24.

Lurachainn, 79

Lus nam bàn sith, 51.

Lus na ban righ, 57 .

Lis nam buadha, 30 .

Lus bhainne, 8 .

Lus bheathag, 55

Lus a bhallaidh, 64 .

Lus bhalgaire, $51,96$.

Lus buidhe mòr, 7 .

Lus buidhe bealtuinn, 2 .

Lus caitheamh, 35 .

Lis a cholamain, 3 .

Lus na cam-bhil, 43.

Lus caolach, 9 .

Lus nan cenamh briste, 56 .

Lus nan cluas, 27.

Lus a choire, 33 .

Lus a chraois, 29

Lus chrann ceusaidh, 61 .

Lus a chrom-chinn, 77

Lus cré, 50.

Lus chosgadh na fòla, 44

Lus a ehridhe, 55 .

Las a chrubain, 47 .

Lins nan cnajan, 50 .

Lus a chorrain, 94 .

Lus an eallan, 12.
Lus na fearnaich, 8, 109

Lus a ghàraid, 27 .

Lus a ghlinne, 63 .

Lus a ghradidh, 59 .

Lus an t' seann duine, $1 \mathrm{CS}$.

Lus na fionnag, 62 .

Lus na fòla, 5 .

Lus na Fraing, 43.

Lus gna-ghorm, 12.

Lus ghonaich, 97.

Lus na h'oidhche, 49.

Lus na h'oidhnan, 25 .

Lus nan laoch, 26.

Lus nan laogh, $2 \bar{T}$.

Lus nan leac, 50 .

Lus an leasaich, 35 .

Lus nan mial, 50,56 .

Lus midhe, 56.

Lus mor, 51.

Lus Mhic Chuimein, 30.

Lus Ihic righ Bhreatainn, 53

Lus Mhic Raonail, 3.

Lus mharsahlidh, 54

Lus na meala, 34.

Lus na nathraich, 56 .

Lis na meall mòr (Appendix)

Lus na cnamb, 31 .

Lus Pharliath, 41

Lus na purgaid, 62.

Lus a phiobair, 54 .

Lus a pheubair, 54

Lus na peighinn, 29.

Lus phione, 3 .

Lus an righ, 53 .

Lus riabhach, 50 .

Lus leth an samhraidh, 6 .

Lus an t'saoidh, 30 .

Lus nan 8corr, 55 .

Lus siode (Appendix).

Lus an t'siabuinn, 8 .

Lus an t'sicnich, 59.

Lus an sith chainnt, 25, 27.

Lus tàghta, 75 .

Lus an tùise, 55 .

Lus na Spaine, 43.

Lus a cholamain, 3 .

Mac gun athair gun mhathair, 81.

Mac-an-dogha, 38

Machall uisge, 19.

Machall coille, 19.

Machall monaidh, 19 .

Madar, 34.

Madar fraoch, 35.

Magairlinn meireach, 75 .

Malip, 11.

Maloimh 10.

Mann, 91 .

Maol dhearc, 66 .

Maothan, 71

Màrag bhuidhe, 7 .

Maraich, am, 5 .

Marbh droighionn, 22

Marbh dhruidh, 22 .

Mathair an duileasg, 102.

Meacan dubh fiadhainn, 54

Meacan each, 5 .

Meacan a chruidh, 32 .

Meacan easa tiorine, 108.

Meacan ragaim, 44.

Meacan dübh, 56 .

Meacan an righ, 32 .

Meacan sleibhe, 3 .

Meacan tobhach dubh, 38.

Meacan ruadh, 5 .

Meal-bhuic, 64 .

Meala, lus na, 34

Meàloigfer corcuir, 89. 
Meangach, 19.

Meanbh pheasair 87.

Meantas, 52.

Mearlag, 95.

Meath chaltuinn, 40

Meidil, crann, 22

Meilbheag, 4.

Meirse, 30 .

Meithan, 84 .

Meoir Mhuire, 15.

Meuran sith, 51 .

Meuran nan daoine màrbha, 51.

Mreuran na càillich mhàrbha, 51.

Mharsalaidh, lus, 54 .

Mial, lus na, 56

Midhe, lus, 56.

Mil mheacan, 10.

Mileid, 87.

Millsean monaidh, 48 .

Millteach, milneach, 81 .

Millteach, uisge, 89 .

Minbhar, 29.

Minmliear, 29.

Min fheur, 90.

Mionag, 46.

Mionnt gliàraidh, 52 .

Mionnt arbhair, 52.

Mionnt each, 52

Mionnt fiadhain, 52 .

Mionnt coille, 52

Mionntas chaisiol, 65.

Miosach, 9.

Miortal, 25

Miothag bhuidhe, 49 .

Mircean, 101.

Mirean nam magh, 22.

Mirr, 33

Mislean, 87.

Mislean uisge, 89.

Misimean dearg, 52 .

Modhalan dearg, 50 .

Modhalan buidhe, 50 .

Moin fheur, 92.

Mointeach liath, 97 .

Mongach mhear, 29.

Mònog. 46.

Mòr fhiliodh, 31.

Mòr, lus, 51.

Mòran, 27, 84.

Mormanta, 39.

Morran, 6.

Moth-uraich, 75 .

Mucaig, preas nam, 21.

Mùchog, 51.

Mughard, 40.

Mugoman, 32

Muilceann, 31, 113.

Muileog, 46 .

Muinmhear, 29.

Muirlinn, 101.

Muisean, 57 .

Mulabhar, 34 .

Mulart, 34

Mullach dubl, 39.

Muran, 32, 84, 88 .

Mur droighionn, 22

Mur dhraidhean, 22.

Mustard, 7.

Nathair lus, 54 .

Nathraich, lus na, 56, 95.

Nead chailleach, 1 .

Neainhnaid, 19.

Neandog, 64, 107.

Neip, neup fiadhain, 6 .

Neul nisge, 2.

Niansgoth, 39.
Nion, 47.

Noinean, 42

Noinean mòr, 43.

Noinean chladaich, 58.

Norn, 27.

Norp, 27

Nuin 47.

Obrun, craobh, 14.

Odharacl mhuillach, 36 .

Odharan, 32

Oidliche, lus an, 49.

Oidhnan, lus na h', 25.

Oighreag, Oireag, 20

Oinsean, 47.

Oir, 13.

Ola, oladh, 46.

Orn, omna, 67.

Onen, 47.

Or mheas, ubhal, 24.

Oraisd, orainis, 24

Oragan, 53.

Orua, 89.

Orp, 27

Oruin, 73.

Pacharan chapuill, 48.

Paipean ruadh, 4.

Partainn dearg, 24.

Pearsail, 30.

Pearsail mhòr, 30.

Peighinn lus na, 29.

Peighinn rioghail, 52.

Peitseag, 18 .

Pesair, 15.

Pesair an arbhair, 16.

Pesair chapuill, 15.

Pesair dubh, 15.

Pesair buidhe, 15.

Pesair nan luch, 15.

Pesair nam preas, 15.

Peur, 23

Pharliath, lus, 41.

Phiobaire, lus, 54.

Phione, lus a, 3.

Pın chrann, 72.

Pis fiadhain, 15.

Pleanntrin, 11.

Plubairsin, 2.

Plumbas, 17.

Plumbas seargta, 17.

Plùr na gaoithe, 1 .

Plùr na gréine, 7,39

Plùr na cubhaig, 6,8 .

Plùr an lochain, 44.

Plùran eluigeannach, 44.

Pobliuill, 70.

Pobul, 41.

Ponair, 16.

Ponair àirneach, 16.

Ponair chapuill, 16, 48 .

Ponair churraigh, 108.

Ponair frangach, 16.

Por-cochullach, 14.

Praiseach bhaidhe, 6 .

Praiseach bhràthair, 60.

Praiseach féidh, 5 .

Praiseach tiadhain, 60.

Praiseach glas, 60 .

Praiseach garbh, 7 .

Praiseach mhin, 60 .

Praiseach nam màra, 59.

Praiseach tràgha, 5 .

Preas deilgneach, 3.

Priobaid, 47.

Probach, 100

Puinneag, 62.

Purgaid, lus na, 62.

Purpaidh, 60.
Rablıagach, 4, 120.

Ragaim, meacan, 44

Racadal, 5.

Radbareain, 50

Raeimin radhairc, 50 .

laidhleadh, 92.

Rail, railaidb, 67 .

Raineach, 92.

Raineach nan erag, 93.

Raineach cruaidh, 93.

Raineach, frioth, 93.

Raineach chuilinn, 93.

Raineach, fảile, 93 .

Raineach, mare, 93.

Raiveach madra, 94.

Raineach Mhuire, 94.

Raineach nan rodainn, 94.

Raineach mhor, 94.

Raineach rioghuil, 95 .

Raineach uaine, 94 .

Raith, 94 .

Ramasg (Appendix).

Ramhdroighionr, 13.

Raonal, lus Mhic, 3 .

Raosar dubl, 26.

Raosar dearg, 26.

Ràs chrann sior uaine, 46.

Reagha maighe (Appendix

Reana, reagam (Appendix

Raeimin-radhairc, 50.

Rein an ruisg, 50 .

Riabhach, lus, 50 .

Riaghal cuil, 12 .

Rial chuil, 12.

Rideog, rileog, 71 .

Righ na coille, 67.

Righeal cuil, 12.

Righean righ, 12 .

Rod, roide, 40,72 .

Roibhe, 44.

Roille, 92 .

Roisnin, 50

Romlian, 91.

Ròs, 17.

Ròs lachan, 82.

Ròs màr, 52

Ròs Mhuire, 52

Ròs Mhairie, 52.

Ròs ant'solais, 8 .

Roineach màra, 103.

Rosòr, 58.

Ruamh, ruain, 35 .

Rne, rugh, ruibh, 1.

Rue ail peach, 1

Rue bèg, 1.

Rue gharaidh, 1.

Ruidel, 12

Ruinn ruise, 58 .

Rnintealas, 92.

Ruis, 34.

Ruiteagan, 20.

Saidse, 53.

Saidse coille, 53 .

Saidse fiadhain, 53 .

Saileog, 70 .

Sail bhuinne, 41 .

Sail chuach, 8 .

Sailigh fhrancaigh, 71.

Saileog, 17.

Saimbhir, 31 .

Samb, 12, 62 .

Samh bo, 12, 62

Samhan, 74.

Samharcan, 57.

Samman, 57.

Saoidh lus an t' 30

Sceallan, 7.

Sealbhag, 62. 
Sealbhag nam fiarh, 62 . Seagall, 89 .

Sealgag, sealgan, 62 .

Seamar, 15.

Seamar cré, 50.

Seamar chapuill, 15.

Seamhair Mhuire, 57 .

Seamrag, 12.

Seamray bhuidhe, 15.

Seangan, 15.

Searbh lìs, 40 .

Searbhag inhilis, 49 .

Searraiche, 2.

Seasg, 86.

Seasgan, 87.

Seathbhog, 54 .

Seichearlan, 57.

Seileach, 70 .

Seileach geal, 71 .

Seileach an t' srutha, 71 .

Seileachan, 25

Seileachan buidhe, 57 .

Seileachan frangach, 25.

Seileastar, 76.

$\mathrm{S}$ sileavtar gall, 86 .

Seileastar amh, $80^{\circ}$.

Seimhan, 85.

Seircean suirich, 38 .

Seisg, mheirg, righ, 83 .

Seisg madraidh, 83 .

Seomar bhan, 14.

Send, 110.

Scathog fiadhain, 86.

Syeachag preas nan, 22.

Sgeachag Mhuire, 44

Sgeach chubhraidh, 21.

Sgeach mhadra, 21.

Sgealag, 7 .

Syeamh na eloch, 92.

Syeamh dharaich, 93.

Syitheach dủhh, 17.

Sgitheach geal, 22 .

Sheudar, 73

Sheudar, fiodh, 73.

Siabuin, lus an, $8,110$.

Sian sleibhe, 57.

Sice, crann, 11.

Sicnich lns an $t^{\prime}, 59$.

Sineamfheadha, 75 .

Sinicin, 27.

Sinnsior, 75 .

Siobaid, 78 .

Siobhas 92
Siothan, an, 51.

Siorralach, 51 .

Siris, 17.

Sitron, 24.

Sith, lus nam ban, 51 .

Sitl cainnt, 25.

Sitl cainne, 57 .

Siunas, 3 L.

Slablicean, slabhagan, 102.

Slan lus, 55, 58.

Slap ehàil, 59 .

Slàt mhàra, 100.

Slàt gòrm, 49.

Sleamhan, 65 .

Slochdan, 102.

Sloucan, 102.

Sinalaig, lus na, 3 )

Smearag, 21.

Smeartan, 101

Smòcan, 103.

Snaithe bhatheadh, 26 .

Sobh, 62.

Sobhrach, soghrach, 56

Sobhrach geamhraidh, 57 .

Soillse nan sùil, 50 .

Soirigh, soradh, 57.

Spaine, lus na, 43.

Sparain, 101.

Spinach, 60.

Spiontag, 26.

Sporran, an, 5, 161.

Spuirse, 63

Sradag, 64.

Sraidin, 5

Sreang bogha, 14.

Sronamh, 78.

Srubhan na múr, 37.

Stalog, lus na, 63 .

Stamh, 100.

Sturdan, 92.

Sùbhag

Subh craobh, 20.

subh thalmhainn, 20.

Subhan laire, 20.

Sủbh, or sùgh dharaich, 33.

Subh nam ban sithe, 109 .

Sugag, 15, 2".

Suicair, lus an $t^{\prime}, 37$.

snidheag, 20.

Suileog, 71.

Suirichean suirich, 3 s.

Surag, 12.
Surabhan, 47 .

Suramont, 40 .

Suthag, 20.

Taga, 36.

Tàghta, lus, 75 .

Tamshae, 43.

Teanga mhin, 54 .

Teanga a nathraich, 95 .

Teanga chù, con, 56 .

Teile, craon, 10.

Tin gealach, 27.

Tir pin, 27.

Tiachd subh, 20

Tonn a chladaich, 58

Torachas biadhain, 2 .

Turman, 53.

Traileach, 100.

Treabhach, 109

Tri bhilean, 15.

Tri bhileach, $35,48$.

Tri ballan, 35

Trioman, 99 .

Trom, 34.

Trombhoid, 51, 113.

Trusgan, 22.

Trusyar, 103.

Tuili(,p, 80.

Tnilm, 67.

Tuir chis, 2.

Tuiremann, 91.

Tuirseach, 9 .

Tuise, 34,53

Tursarrain, 9.

Tursarranin, 9.

Turusgar, 103.

Uachdar, 56.

Uath, 23

Ubhal, 23.

Ucus, 10.

Ucus frangach, 10.

Urus fheadhair, 10.

Uile ioc, 33.

Uillean, 34 .

Uinnean, 78.

Uinnsean, 4i, 115.

Ur ùine, 60

Ur thalmhainn, 94.

Ura bhallach, 36 .

Urach bhallach, 75 .

Urach inhullaich, 36 .

\section{ENGLISH AND SCIENTIFIC.}

Acer, 11

Aceraceæ, 11.

Achillea, 44.

Aconitum, 3.

Acorus, 82

Adders' tongue, 95.

Adiantum, 95.

Egopodium, 32

Agaricus, 99.

Agrimony, 22

Agrostis, 87 .

Aira, 92 .

Ajuga, 54.

Alaria, 101.

Alchemilla, 22.

Alder, 68.

Alexanders, 30.

Algæ, 100 .
Alisnıa, 81.

All-heal, 33.

Alliaria (Appendix).

Allium, 78.

Almond, 18.

Alnus, 68 .

Aloe, 77.

Alopecurus, 87.

Alpine Ladies' Mantle, 22.

Althæa, 10.

Amaranthus, 59.

A maryllidaceæ, 77 .

Amentiferæ, 66 .

Ammophila, 88.

Amygdalus, 18.

Anagallis, 58 .

Anemone, 1.

Anethum, 32 .
Angelica, 31, 107.

Anthemis, 43 .

Authoxanthum, 87.

Anthriscus, 32.

Anthyllis, 15.

Apium, 30.

Apple, 23.

Apricot, 17.

Aqnilegia, 3.

A raliaceæ, 28

Arbutus, 45, 107 .

Archangel, 54

Arctium, 38.

Areuaria 9.

Aristolochia, 62

Aristolochia fam., 62.

Armoracia rusticana, 5 .

Armeria, 58. 
Arrow-grass, 81

Artemisia, 39.

Artichoke, 39.

Arum, 82.

Alundo, 8\%.

Asarum, 62

Ash, 47.

Ash (mountain), 24

Asparagus, 80.

Aspen, 70 .

Asperula, 35 .

Asphodel bog. 8?.

Asplenium, 94

Athyrium, 94.

Atriplex, 60 .

A нrantiacex, 24.

Auricula, 57.

Avena, 88.

Avens, 19 ; water, 22.

Baldmoney, 31.

Ballota, 54.

Barbarea, 109.

Barberry, 3.

Barley, 89

Bay-tree, 60.

Beam-tree quick, (Appendix).

Bean, 16

Bearberry (black), 45.

Beech, 67 .

Beet, 59 .

Belladona, 49 .

Bellis, 42.

Berberidaceæ, 3.

Beta, 59.

Betonica, Stachys, 55.

Betony, 55.

Betula, 68 .

Bidens, 44.

Bilberry (whortleberry), 45.

Bindweed, 18.

Birch, 68

Bird cherry, 18.

Bird's-foot trefoil, 15.

Bishop-weed, 32.

Bistort, 61.

Bitter-sweet, 49.

Bitter vetch, 16.

Blackberry (bramble), 21.

Black bind weed, 61 .

Black horehound, 54.

Blackthorn, 17.

Bladder-fern, 93.

Blechnum, 93.

Bluebell, 44, 80 .

Bluebottle, 39.

Bog-asphodel, 80 .

Bog-berry, 46 .

Bog-moss, 97

Bog-myrtle, 71, 105.

Bog-violet, 56.

Boletus, 99 .

Borage, 55.

Borago, 55 .

Botrychium, 95

Box, 63.

Brakes, 94

Bramble, 20.

Brassica, 6.

Briar (sweet), 21.

Briza, 9'.

Brome grass, 88 .

Brook-lime, 49.

Broom, 14.

Broonl-rape, 51.

Bruise-wort, 8.

Bryaceæ, 97.

Buckbean, 48

Buckthorn, 13.
Buckwlieat (climbing), 61.

Bugle, 54.

Bugloss, 55 .

Bullace, 17.

Bulrush, 85.

Bunium, 30.

Burdock, 38 .

Bur marigold, 44.

Burnet, 22.

Bur-reed, 83.

Rutcher's broom, 80 .

Bntterbur, 4l.

Buttercups, 2.

Butterwort, 56.

Buxus, 63.

Cabbage, 6 .

Cakile, 6.

Calamagrostis, 88

Calamint, 52 .

Calluna, 45.

Caltha palustris, 2.

Camomile, 43

Campanulacere, 44.

Campion (red), 8.

Cane-grass, 88.

Capsella, 5

Caraway, 30.

Cardamine, 6

Carduus, 38, 114.

Carex, 86

Carpinus, 67.

Carrot, 32.

Carum, 30.

Caryophyllacese, 8 .

Castanea 69.

Cat's-tail, 82.

Cauliflower, 6.

Cedar, 73.

Celandine (common), 4.

Celandine (lesser), 2, 107.

Celastracea:, 12.

Celery (wild), 30.

Centaurea, 39.

Centaury, 48.

Cerastium, 9 .

Charlock, 7 .

Chase-the-devil, 3.

Cheiranthus, 6.

Chelidonium, 4.

Chenopodiaceæ, 59.

Chenopodium vulvaria, 60 .

Cherleria, 9.

Cherry, 17; wild, 18.

Chervil, 32

Chestnut, 69.

Chick weed, 9.

Chicory, 37.

Chives, 79.

Chlora, 48.

Chondrus, 102

Chorda, 1u3

Chrysanthemum, 42.

Chrysosplenium, 27.

Cicely (sweet), 33

Cicuta, 29.

Cinquefoil, 19.

Cinnamon 60.

Circaa, 25.

Cistacex, 7.

Citrus, 24.

Citron, 24.

Clary, 53.

Cleavers, 34

Cloudberry, 20.

Clover, 14 ; red, 15

Clubmoss, 96.

Cochlearia, 5.

Colchicum, 77.
Colt's-foot, 41.

Columbine, 3 .

Comarum, 19.

Comfrey, 56

Common cotton rose, 40 .

Compositæ, 36 .

Conferva, 103.

Coniferæ, 72.

Conium, 29.

Convallaria, 78

Convolvulaceæ, 48 .

Convolvulus, $4 \AA$.

Corallina, 102.

Coriander, 33.

Cork-tree, 67.

Curnaceæ, 28.

('orn-cockle, 8.

Cornel, 28.

Corn-marigold, 42.

Corn-sow thistle, 37.

Corn-thistle, 38 .

Cornus, 28.

Cotton-grass, 86.

Cotton sedge, 86 .

Cotyledon, 27, 107.

Couch grass, 91.

Cow. berry, 45.

Cow-parsnip, 32

Cowslip, 57, 105.

Crab-tree, 23.

Crambe, 5, 108.

Cranberry, 46.

Cranesbill, 12.

Crassulaceæ, 26.

Crategus, 22.

Cress (water), 6.

Crithmum, 31.

Crocus, 77.

Crowberry, 62.

Crowfoot farn., 2.

Cruciferæ, 5.

Cryptogams 92.

Cuckno-flower, 6 .

Cuckoo-pint, 82 .

Cucumber, 63.

Cucurbitaceæ, 63.

Cudbear, 98.

Cudweed, 40.

Cupuliferæ, 66

Currant. 26.

Cuscuta, 49

Cyclamen, 57.

Cynoglossum, 56

Cynosurus, 90.

Cyperaceæ, 84.

Cypress, 73.

Cystopteris, 93.

Cytisus, 14.

Daffodil, 77.

Daffy-down-dilly, 77 .

Daisy, 42.

Damson, 17

Dandelion, 37.

Danewort, 34.

Darnel, 91.

Dancus, 32.

Deadly nightshade (atropa), 49

Dead nettle, 54, 108.

Devil-in-the-bush, 3 .

Devil's hit, 36 .

Dewberry, 21.

Dictamnus, 54.

Digitalis, 51.

Dill, 32.

Dipsaceæ, 36.

Dipsacus, 36 .

Dittany, 54. 
Dock, 61.

Dodder, 49.

Dog lichen, 97.

Dog's - mercury (wood mercury). 63.

Dog-tail, 90 .

Dog-rose, 21.

Dog-violet, 7 .

Dog-wood, 28.

Dropwort, 18.

Drosera, 8, 106.

Dryas, 19.

Duckweed, 81.

Dulse, 101.

Dwale, 49.

Dwarf beech, 69 .

Dwarf elder, 34.

Dwarf mallow, 10.

Earth-nut, 30.

Echium, 56 .

Elder, 34.

Elecampane, 42.

Elm, 65 .

Empetrum, 62

Enchantress nightshade, 25 .

Eadive, 37.

Epilobium, 25.

Epipactis, 76.

Equisetaceæ, 96

Equisetum, 96.

Erica, 44

Ericaceæ, 44

Eriophorum, 85.

Ervium, 16

Eryngium, 29, 94.

Erysinum, 6, 107.

Erythræa, 4S.

Fuonymus, 13.

Eupatorium, 43.

Euphorbiacea, 63 .

Euphorbia, 63.

Euphrasia, 50.

Everlasting, 40.

Eyebright, 50.

Faba, 16.

Fairy flax, 9.

Fagus, 67.

Fennel, 30.

Feningreek, 14.

Fern family, 92.

Fescue grass, 90.

Festuca, 90

Ficus, 65 .

Field madder, 34 . .

Fig, 65.

Figwort, 50 .

Filago, 40

Filices, 92, 106.

Fiorin grass, 87.

Fir, 72.

Flag (yellow), 76

Flax, 9.

Flixweed, 6.

Foniculuin, 30

Forget-me-not, 56 .

Foxglove, 51.

Fuxtail grass, 87.

Fragaria, 19

Fraxinus, $4 \%$.

French bean, 16

French willow, 71 .

Fucus, 1 0 .

Fumaria, 4, 106, 107.

Fnmariaceæ, 4.

Fumitory, 4.

Fungi, 99 .

Furze, 14.
Galanthus, 77.

Gale, 71

Galeopsis, 55.

Galium, 34 .

Garlic, 79.

Garlic mustard, 6 .

Gentian, 47.

Gentiana, 47 .

Gentianaceæ, 47.

Geraniaceæ, 12.

Geranium, 12.

Geum, 19 .

Gilliflower, 6 .

Glasswort, 59

Glancium, 4.

Globeflower, 6 .

Glyceria, 89.

Gnaphalium, 40 .

Golden rod, 44.

Golden saxifrage, 27.

Goldilocks, 2

Good King Henry, 60.

Gooseberry, 26 .

Goosefoot, 60 .

Goosegrass (seaside), 59.

Gorse, 14

Goutweed, 32

Gramineæ, 87.

Grape vine, 12

Grass family, 87 .

Grass of-Parnassus, 28.

Grassrack (sea-grass), 81.

Ground ivy, 54.

Groundsel, 41

Guelder rose, 34 .

Harebell, 44.

Hare's-foot clover, 15.

Hart's-tonque fern, 94.

Halydris, 103.

Hawkweed, 37, 108.

Hawkweed (mouse-ear), 37.

Hawthorn, 22.

Hazel, 68

Heartsease (Appendix)

Heath, 44

Heath bedstraw, 35 .

Heath, Cornish, 45.

Hedera, 28, 106

Hedge mustard, 10s.

Helianthemum, 7 .

Hellebore (green), 3.

Hellebore, 3 .

Helleborine (white), 76

Helleborus, 3.

Helinintha, 36 .

Helosciadium, 30.

Heinanthalia, 108 .

Hemlock, 29.

Hemp 64.

Hemip agrimony, 43.

Hemp nettle, 55 .

Henbane, 49

Heracleum, 32, 107.

Herb Rohert, 12 .

Herniaria, 59.

Hieracium, 37.

Holcus, 9u.

Hully, 46.

Holly fern, 93.

Hollyhock (Appendix), 108

Holm-tree, 67.

Holostea, 9

Honeysuckle, 34 .

Hop, 64.

Hop trefoil, 15

Hordeuin, 89.

Horehound, 54

Hornbeam, 68 .
Horse-chestnut, 69 .

Horse-radish, 5 .

Horse-tail, 5 .

Hounds-tongue, 56

House-leek, 27.

Hyacinth (wild), 80.

Hydrocotyle, 29.

Hyoseyamus, 49

Hypericum, 10.

Hyssop, 54.

Ilex, 46.

Inula, 42.

Iridaceæ, 76.

Iris, 76.

Isatis, 5 .

Ivy, 28, 106.

Jasione, 44

Juglans, 14.

Juncaceæ, 83

Juncus. 83.

Juniper, 74

Juniperus, 74 .

Kale, 5, 6 .

Kidney vetch, 15 .

Knapweed, 39 .

Knautia, 36.

Knot-grass, 61.

Labiatæ, 52.

Laburnum, 14

Lactuca, 36 .

Lady fern, 94.

Ladies' bedstraw, 35

I adies' fingers, 15.

Ladies' mantle, 22.

Ladies' smock, 6 .

Lammaria. 101.

Lamium, 54.

Lapsana, 37.

Larch, 73

Lastrea, 93.

Lathjrus, 15.

Laurel, 60 .

Lavender, 53.

Lecanora, 98.

Jeek 78.

Leguminosæ, 14

Lemon, 24.

Lemna, 81.

Lemnaceæ, 81 .

Lentiles, 16

Leontodon, 37 .

Lepturus, 88.

Lepidium, 54

Lettuce, 36 .

Lichens, 97.

Ligusticum, 31.

Lilac, 46

Liliaceæ, 78.

Lily-of-the-valley, 78 .

Lime, 10.

Linaceæ, 9.

Linden, 10.

Ling, 45.

Linum, 9.

Listera, 76.

Liverwort, 97 .

Lnbelia, 44.

Lolinm, 91

London Pride, 105.

Lonicera, 34.

Loosestrife (purple), 25.

Loosestrife (yellow), 57.

Loranthaceæ,

Lords and ladies, 82.

Lotus, 15. 
Louse-wort, 5 .

Lovage, 31 .

Lovage (conimon), 31.

Lunaria (moonwort), 95.

Lungwort, 98.

Luzula, 84 .

Lychnis, 8, 106.

Lycoperdon, 99.

Lycopodiaceæ, 96.

Lycopodium, 96.

Lycopos, 55.

Lysimachia, 57.

Lythracex, 25 .

I.y thrum, 25.

Madder, 34

Maiden-hair fern, 95 .

Male fern, 93

Mallow, 14.

Malva, 10.

Malvacege, 10

Mangel-wurzel, 59.

Maple, 11

Maram, 88.

Marchantiaceæ, 97

Marigold (corn), 42.

Marjoram, 53.

Iarrubium, 54

Marsh cinquefoil, 19.

Marsh-mallow, 10.

Marsh-marigold, 2

Marsh-pennywort, 29.

Marsh-thistle, 38

Mary's thistle, 33.

Marshwort, 30 .

Masterwort, 31

Mat-grass, 92.

Matricaria, 43.

May, 22.

Mayweed, 43.

Meadow-rue, 1.

Meadow saffron, $\pi$.

Meadow-sweet, 18.

Meadow saxifrage, 27.

Medlar, 22

Melancholy thistle, 38 .

Melon, 64.

Mentha, 52 .

Menyanthes, 48 .

Mercurialis, 63 .

Mercury, 63.

Mespilus, 22.

Meu, 31.

Meuin, 31, 113.

Mildews, 99.

Milfoil (water), 26.

Milkwort, 8

Millet, s7.

Mint, 52 .

Mistletoe, 33, 114

Molinia, 89 .

Monkshood, 3

Monk's rhuliarb, 22 .

Moonwort, 95.

Morus, 66.

Mosses, 97 .

Moulds, 69 .

Mountain-ash, 24, 112.

Mountain-sorrel, 62

Mucedo, 99.

Mugwort, 39

Mulberry, 66.

Mullein, 49.

Mushrooms, 99

Mustard (wild), 7 .

Myosotis, 56 .

Myrica, 71, 105.

Myriophyllum, 26

Myrrhis, 33 .
Myrtle, 25.

Naiad family, 81 .

Nareissus, 77 .

Nard (Celtic), 67.

Nardus, 92, 106, 107.

Narthecium, 80

Nasturtium, 6, 109

Navelwort, $2 \bar{i}, 107$.

Nepeta, 54

Nettle, 64 .

Nigella, 3

Nightshade, 49.

Nipplewort, 37 .

Nuphar, 4

Nyinphæaceæ, 3 .

Oak, 66, 114

Oak fern, 93.

Oats, 88.

Olea, 46.

Olive, 46.

Onion, 78.

Ononis, 14, 169 .

Onopord (Aplendix), notes, 114.

Ophioglossum, 95.

Ophrys, 75.

Orache, 60.

Orange, 24.

Orchidacea, 75

Orchid fain., 75

Origanum, 53 .

Orobanche, 51.

Orolus, 16, 108, 114

Orvine, 27.

Osier, 71

Osmunda, 95.

Oxalis, 12.

Ox-eye daisy, 43

Ox-tongue, 55.

Pxonia, 3.

Pæony, 3, 1.8

Pansy (dppendix), 107, 109.

Papaver, 4.

Papaveraceæ, 4.

Papilionaceæ, 14.

Parietaria

Parmelia, 98.

Parnassia, 28.

Parsley, 30.

Parsnip, 32, 113.

Pastinaca, ๖2, 113.

Pea, 15.

Peach, 18.

Pear, 23.

Pedicularis,

Pellitory, 64 .

Pellitory of Spain, 43

Peltidea, 97.

Pennyroyal, 52

Penny wort, 29.

Pennycress, 5 .

Peplis (Euphorbia), 63.

Pepperwort, 54 .

Persicaria, 61.

Petasites, 41.

Petroselinum, 30.

Phleum, 87.

Phœnix, 106.

Pignut, 30.

Pinupernel, 58.

Pinguicula, 56.

Pine, 72

Pine family, 72.

Pinus, 72.

Pisun, 15.

Plane, 11.
Plantaginaceæ, 58.

Plantago, 58.

Platanus, 11.

Plum, 17.

Plumbagineæ, 58.

Porphyra, 102.

Polyanthus, 57,

Polygalaceæ, 8.

Polygonaceæ, 61 .

Polygonum, 61.

Poly podium, 9?.

Polypody, 92.

Polyporus, 99.

Polysiphonia, 102.

Polystichum, 93.

Pomegranate, 25.

Pond-weed, 81.

Poplar, 70.

Poppy, 4.

Poppy (horned), 4.

Poppy (somniferum), 4.

Populus, 70.

Potamogreton, 81.

Potato, 49.

Potentil, 19, 1( 5 .

Primrose, 56.

Primrose fam., 56.

Primula, 56.

Primulaceæ, 56.

Privet, 46

Prunella, 55.

Prunus, 17,107

Psamina, 88.

Pteris, 94.

Puff-ball, 99.

Pulmonaria, 98 .

Punica, 25.

Purple lonsestrife, 25.

Purslane-like orache, 60.

Pyrus, 23.

Quick beam, 107.

Queen of the meadow, 1s, 105.

Quaking-grass, 90.

Quercus, 66, 114.

Quince, $2 \pm$.

Radish, 5, 108.

Ragged rolin, 8 .

Ragwort, 42.

Ranunculaceæ, 1.

Rauunculus family, 1 .

Raphanus, 5.

Raspberry, 20.

Rattle (yeilow), 50, 107.

Red campion, 8.

Red rattle, 50 .

Reed, S7.

Reed-grass, $s 8$.

Reed-1nace, 82 .

Reseda, 7.

Resedaceæ, 7.

Rest-harrow, 14.

Rhamnus, 13.

Rhinanthus, $50,1(i$.

Rhodiola, 26.

Rhodymenia, 101.

Rhubarb (Monk's), + 2

Ribes family, 26.

Ribwort, $5 \mathrm{~S}$.

Rocket, 6.

Rocambole, 79 .

Rock-rose, 7 .

Rosaceæ, 17.

Rosebay, 25.

Rosemary, 52.

Roseroot, 26.

Rowan-tree, 24, 112 
Royal fern, 95.

Rubia, 34.

Rubiaceæ, 34.

Rubus, 20 .

Rue, 1.

Rue fern, 94.

Rumex, 61 .

Rupture-wort, 59.

Ruscis, 80.

Rush family, 83, 84 .

Ruta (graveolens), 1.

Rye, 89.

Rye-grasจ, 91.

Saffron, 77 .

Sage, 53

St John's wort, 1', 110.

Salicaria, 25.

Salicornia, 59.

Salix, 70.

Sallow, 71 .

Salt-wort, 59 .

Sambncus nigra, 34, 113.

Samplire, 31.

Sandalwood (Appendix), 106.

Sandwort, 9.

Sanguisorba, 22.

Sanicle (wood), 29.

Santalum, 106 .

Saponaria, 8, 110.

Sargassum, 103

Sarothamnis, 14

Sauce-alone, 6, 105.

Savin, 74

Savory, 53

Saxifraga, 27.

Saxifrage, 27.

Scabiosa, 36

Scabious, 36

Sclwenus, 85, 120.

Seilla, 80.

Seirpus, 85 .

Scolopendrimn, 94.

Scouring rush, 97.

Scrophularia, 49, 106

Scrophulariacex, 49 .

Scurvy-grass, 5, 105.

Sea gilly-flower rocket, 6 .

Sea liolly, 29, 94 .

Sea-kale or cabbage, $5,108$.

Sea matweed, 88 .

sea rocket, 6 .

Sea spurge, 63.

Seaweeds, 100.

Sea wheat-grass, 91 .

Seaware, 100

Secale, 89 .

Sedige, 87.

Sedum, 26.

Selago, 96 .

Self-heal. 55

Sempervivum, 27, 109.

Senecio, 41

Serrated seaweed, 100.

Shallot, 79 .

Shamrock, 12.

Sheep's-bit, 44.

Sheep sorrel, 62

Shepherd's-purse, 5

Shepherd's weatherglass, 58 .

Shieldfern, 93.

Silverweed, 19, 106.

Sinajis, $7,105$.

Sisymbrium, 6.

Sium, 32.

Skirrets, 32, 106

Sloe, 17, 109, 115

Sinallage, 30

Snakeweed, 61 .

Sneezewort, 41
Snowdrop, 77

Soapwort, 8, 110 .

Soft tinder, 99.

Solanaceæ, 49.

Solanum, 49.

Solidago, 44.

Sonchus, 36 .

Sorrel, 62

Southernwood, 40.

Sow-bread (cyclamen), 57 .

Sow-fennel, 31 .

Sow-thistle, 36.

Sphagnum, 97.

Sparganium, 83.

Spearwort, 2.

Speedwell, 50

Spergula, 9, 106.

Spignel, 31 .

Spinage, 59.

Spindle-tree, 13

Spiræea, 18.

Spleenwort, 94.

Spurge, 63.

Spurry, 9, 106.

Squill, $8 \%$.

Stacliys, 55 .

Stellaria, 9.

Sticta, 98 .

Stitehwort, 9 .

Stonebramble, 20.

Stonecrop, 26.

Strawberry, 20.

Strawberry-tree, 45 .

Suæda, 59.

Succisa (eabiosa), 36 .

Succory, 37

Sundew, 8, 106.

Sunflower, 39

sweet hriar, 21.

Sweet flag, 82.

sweet mountain fern, 93 .

Sweet violet, $T$.

Sweet woodruff, 35.

Sycamore, 11.

Symphytum, 56 .

Syringa, 45.

Tanacetum, 43.

Tansey, 43.

Taraxacum, 37, 105.

Taxus, 74.

Teasel, 36

Telephium, 27.

Teucrium, 53.

Thalictrum, 1.

Thistle, 38 .

Thlaspi, 5 .

Thrifr, 58.

Thuga, 73.

Thyme, 53.

Thymus, 53 .

Tilia, 10.

Tiliacere, 10

Timothy grass, 87.

Tormentilla, 19, 197.

Trefoil, 14

Trichomanes. 94.

Trigonella, 14.

Trifolium, 14

Triglochin, 81 .

Tritieum, 90.

Trollius, 16.

Truffle, 99.

Tufted vetch, 15 .

Tuber, 99.

Tulip, 80.

Turnip, 6.

Tussilago, 41.

Tutsan 11

Twayblade, 76 .
Typha, 82.

Typhaceæ, 82

Ulex, 14.

Ulmus, 65 .

Ulva, 102.

Umbelliferæ, 29.

Urtica, 64 .

Urticaceæ, 64.

Vaccinium, 45, 106.

Valerian, 35.

Valerian dwarf, 35.

Valeriana, 35

Verbascum, 49 .

Verbena, 51, 116.

Verbenacee, 51.

Vernal-grass, 87.

Veronica, 50, 107.

Vervain, 51, 116.

Vetch, 15 .

Viburnum opulus, 34, 106.

Vicia, 15, 108

Viola family, 7 .

Violaceæ, 7

Viper's bugloss, 56 .

Viscum album, 33.

Vitis, 11.

Vine, 12 .

Wake-robin, 82.

Wall hawkweed, 37.

Wallflower, 6.

Wall pepper, 26.

Wall pennywort, 27.

Wall rue, 94.

Walnut, 14.

Water crow foot, 2.

Warteress, 6.

Water elder, 34

Water hemlock, 29.

Water-lily, 3 .

Water-milfoil, 26.

Water parsnip, 32.

Water pepper, 61 .

Water plantain, 81 .

Water avens, 19

Way faring-tree, 34 .

Weld, 7.

Wheat, 90 .

Whin, 14.

White tansy, 19.

White thorn, 22.

Whortleberry, 45 .

Wild navew, 6

Willow, 70 .

Willow herb, 25.

Winherry (bilberry),

Wind-flower, 1.

Winter cress, 109.

Woad, 5

Wolfsbane, 3 .

Woodbine, 34

Woodruff, 35.

Wood sage, 53.

Wood sorrel, 12

Wood strawberry, 19.

Wormwood, 40.

Woundwort, 54.

Yarrow, 44, 115.

Yellow flag, 76 .

Yellow bedstraw, 35

Yellow-weed, 7.

Yellow rattle, 50, 107.

Yellow vetchling, 15.

Yellow-wort, 48 .

Yew, 74.

Zostera, $\mathbf{8 1 .}$ 


\section{A T A L O G U E}

OF

MESSRS BLACKWOOD \& SONS'

P U B L I C A T I 0 N S. 


\section{PHILOSOPHICAL CLASSICS FOR ENGLISH READERS.}

\section{Edited By WILLIAM KNIGHT, LL.D.,}

Professor of Moral Philosophy in the University of St Andrews.

In crown 8vo Volumes, with Portraits, price $3^{\text {s. } 6 \mathrm{~d} .}$

\section{Now ready-}

I. Descartes. By Professor Maraffy, Dublin.

II. Butler. By Rev. W. Lucas Colurss, M.A.

III. Berkeley. By Professor Fraser, Edinburgh.

IV. Fichte. By Professor Adamson, Owens College, Manchester.

V. Kant. By William Wallace, M.A., LL.D., Merton College, Oxford.

The Volumes in preparation are-

Hamiton. By Professor Veitch, Glasgow. Hoвbes. By Professor Croom Robertson,

HuMe. By the Editor.

Bacon. By Professor Nichol, Glasgow.

Hegel. By Professor Edward Caird, Glas-

\section{London.}

Spinoza. By Dr Martineau, Principal of Manchester New College.

Vrco. By Professor Flint, Edinburgh.

In COURSE of Publication.

\section{FOREIGN CLASSICS FOR ENGLISH READERS.}

\section{Edited BX Mrs OLIPHANT.}

In Crowu 8vo, 28. $6 \mathrm{~d}$.

The Volumes published are-

Dante. By the Editor.

Voltaire. By Major-General Sir E. B. Hamley, K.C.M.G.

Pascal. By Principal Tulloch.

Petrarch. By Henry Reeve, C. B.

Gorthe. By A. Hayward, Q.C.

Molik̀re. By the Editor and F. Tarver, M.A.

Montaigne. By Rev. W. L. Collins, M.A.

Rabelais, By Walter Besant, M.A.
Calderon. By E. J. Hasell.

Saint Simon. By Clifton W. Collins, M.A. Cervantes. By the Editor.

Corneille and Racine. By Henry M. Trollope.

Madame de SEvigné. By Miss Thackeray. La Fontaine, and other French FabuLIsts. By Rev. W. Lucas Collins, M.A. Schiller. By James Sime, M.A., Author of 'Lessing : his Life and Writings.'

\section{In preparation-}

Roussead. By Henry Graham.-Tasso. By E. J. Hasell.

Now COMPLete.

\section{ANCIENT CLASSICS FOR ENGLISH READERS.}

\section{Edited bY the Rev. W. LUCAS COLLINS, M.A}

Complete in 28 Vols. crown $8 \mathrm{vo}$, cloth, price $2 \mathrm{~s}$. $6 \mathrm{~d}$. each. And may also be had in

$x_{4}$ Volumes, strongly and neatly bound, with calf or vellum back, $£_{3}$, ros.

Saturday Review. - "It is difficult to estimate too highly the value of such a series as this in giving 'English readers' an insight, exact as far as it goes, into those olden times which are so remote and yet to many of us so close." 


\section{A T A L O G U E}

OF

\section{MESSRS BLACKWOOD \& SONS'}

\section{PUBLICATIONS.}

ALISON. History of Europe. By Sir Archibald Alison, Bart.,

D.C.L.

I. From the Commencement of the French Revolution to the Battle of Waterloo.

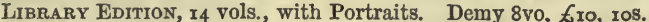

ANOTHER EDITION, in 20 vols. crown 8vo, $£ 6$.

People's Edition, 13 vols. crown 8vo, Ł2, iss.

2. Continuation to the Accession of Louis Napoleon.

LIBRARY EDITION, 8 vols. 8 vo, $£ 6,7$ s. $6 \mathrm{~d}$.

PEOPLE's Edition, 8 vols. crown 8vo, 34s.

3. Epitome of Alison's History of Europe. Twenty-ninth Thousand, 7s. $6 \mathrm{~d}$.

4. Atlas to Alison's History of Europe. By A. Keith Johnston. LIBRARY EDITION, demy 4 to, $£_{3}, 3$ s.

PeOple's Edition, 3is. 6d.

Some Account of my Life and Writings: an Autobiography of the late Sir Archibald Alison, Bart., D.C.L. Edited by his Daughter-inlaw. 2 vols. 8vo, with Portrait engraved on Steel.

[In the Press.

Life of John Duke of Marlborough. With some Account of his Contemporaries, and of the War of the Succession. Third Edition, 2 vols. 8vo. Portraits and Maps, $30 \mathrm{~s}$.

Essays : Historical, Political, and Miscellaneous. 3 vols. demy $8 \mathrm{vo}, 45$ s.

Lives of Lord Castlereagh and Sir Charles Stewart, Second and Third Marquesses of Londonderry. From the Original Papers of the Family. 3 vols. 8 vo, $£ 2$, 2 s.

Principles of the Criminal Law of Scotland. 8vo, 18s.

Practice of the Criminal Law of Scotland. 8vo, cloth boards, I8s.

The Principles of Population, and their Connection with Human Happiness. 2 vols. 8 vo, 30 s.

ALISON. On the Management of the Poor in Scotland, and its Effects on the Health of the Great Towns. By William Pulteney Alison, M.D. Crown 8vo, 5s. 6d.

ADAMS. Great Campaigns. A Succinct Account of the Principal Military Operations which have taken place in Europe from $x_{796}$ to 1870 . By Major C. ADAMs, Professor of Military History at the Staff College. Edited by Captain C. COOPER KING, R.M. Artillery, Instructor of Tactics, Royal Military College. 8vo, with Maps. I6s. 
AIRD. Poetical Works of Thomas Aird. Fifth Edition, with Memoir of the Author by the Rev. JARDINE WALLACE, and Portrait. Crown 8vo, 7s. 6d.

The Old Bachelor in the Old Scottish Village. Fcap. 8vo, 4s.

ALLARDYCE. The City of Sunshine. By Alexander AllarDrce. Three vols. post 8vo, $6 \mathrm{x}, 5 \mathrm{~s} .6 \mathrm{~d}$.

Memoir of the Honourable George Keith Elphinstone, K.B., Viscount Keith of Stonehaven Marischal, Admiral of the Red. One vol.

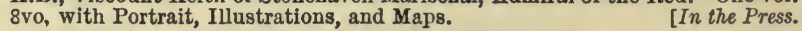

ANCIENT CLASSICS FOR ENGLISH READERS. Edited by Rev. W. LuCAs Collins, M.A. Complete in 28 vols., eloth, 28. 6 d. each; or in $I_{4}$ vols., tastefully bound, with calf or vellum back, $£_{3}$, Ios.

Contents of the Series.

Homer: The Illad. By the Editor.

Homer: The ODYssey, By the Editor.

Herodotus. By George C. Swayne, M.A.

XENOPHON, By Sir Alexander Grant,

Bart., LL. D.

Euripides. By W. B. Donne.

Aristophanes. By the Editor.

Plato. By Clifton W. Collins, M.A.

LuCian. By the Editor.

EEsch Ylus. By the Right Rev. the Bishop of Colombo.

SophocLes, By Clifton W. Collins, M.A.

Hesiod and Theocis. By the Rev. J. Davies, M.A.

Greek Anthology. By Lord Neaves.

Virall. By the Editor.

HORACE. By Sir 'Theodore Martin, K.C.B.

Juvierat Lucretius. By W. H. Mallock, M.A.

AYLWARD. The Transvaal of To-day: War, Witcheraft, Sports, and Spoils in South Africa. By ALFred AyLward, Commandant, Transvaal Republic; Captain (late) Lydenberg Volunteer Corps. Second Edition. Crown 8vo, with a Map, 6s.

AYTOUN. Lays of the Scottish Cavaliers, and other Poems. By W. Edmondstoune Aytoun, D.C.I., Professor of Rhetoric and Belles-Lettres in the University of Edinburgh. Twenty-eighth Edition. Fcap. 8vo, 78. 6d.

An Illustrated Edition of the Lays of the Scottish Cavaliers. From designs by Sir Noel PATON. Small 4 to, 2 rs., in gilt cloth.

Bothwell : a Poem. Third Edition. Fcap., 7s. 6d.

Firmilian; or, The Student of Badajoz. A Spasmodic Tragedy. Fcap., 5s.

Poems and Ballads of Goethe. Translated by Professor A YToun and Sir Theodore MArTin, K.C.B. Third Edition. Fcap., 6s.

Bon Gaultier's Book of Ballads. By the SAME. Thirteenth Edition. With Illustrations by Doyle, Leech, and Crowquill. Post 8vo, gilt edges, $8 \mathrm{~s} .6 \mathrm{~d}$.

The Ballads of Scotland. Edited by Professor Artoun. Fourth Edition. 2 vols. fcap. 8 vo, i2s.

Memoir of William E. Aytoun, D.C.L. By Sir Theodore Martin, K.C.B. With Portrait. Post 8vo, x2s.

BAGOT. The Art of Poetry of Horace. Free and Explanatory Translations in Prose and Verse. By the Very Rev. Daniel Bacot, D.D. Third Edition, Revised, printed on papier vergé, square 8vo, 58. 
BAIRD LECTURES. The Mysteries of Christianity. By T. J. Crawrord, D.D., F.R.S.E., Professor of Divinity in the University of Edinburgh, \&c. Being the Baird Lecture for 1874 . Crown 8 vo, $7 \mathrm{~s} .6 \mathrm{~d}$.

Endowed Territorial Work: Its Supreme Importance to the Church and Country. By William Smiti, D.D., Minister of North Leith. Being the Baird Lecture for 1875 . Crown $8 \mathrm{vo}$, $6 \mathrm{~s}$.

Theism. By Robert Flint, D.D., LL.D., Professor of Divinity in the University of Edinburgh. Being the Baird Lecture for 1876 . Third Edition. Crown 8vo, 78. 6d.

Anti-Theistic Theories. By the Same. Being the Baird Lecture for 1877 . Second Edition. Crown 8vo, ros. 6d.

BATTLE OF DORKING. Reminiscences of a Volunteer. From 'Blackwood's Magazine.' Second Hundredth Thousand. 6d.

By the SAME AUTHOR.

The Dilemma. Cheap Edition. Crown 8vo, 6s.

BEDFORD. The Regulations of the Old Hospital of the Knights of St John at Valetta. From a Copy Printed at Rome, and preserved in the Archives of Malta; with a Translation, Introduction, and Notes Explanatory of the Hospital Work of the Order. By the Rev. W. K. R. BEDFORD, one of the Chaplains of the Order of St John in England. Royal 8vo, with Frontispiece, Plans, \&c., 7 s. 6d.

BESANT. Readings from Rabelais. By Walter Besant, M.A. In one volume, post 8vo. [In the press.
[I

BLACKIE. Lays and Legends of Ancient Greece. By JoHN STUART Blackie, Professor of Greek in the University of Edinburgh. Second Edition. Feap. 8vo. 5s.

BLACKWOOD'S MAGAZINE, from Commencement in 1817 to June r880. Nos. I to 776 , forming 127 Volumes.

Index to Blackwood's Magazine. Vols. I to $50.8 \mathrm{vo}$, I $5 \mathrm{~s}$.

Tales from Blackwood. Forming Twelve Volumes of Interesting and Amusing Railway Reading. Price One Shilling each in Paper Cover. Sold separately at all Railway Bookstalls.

They may also be had bound in cloth, r8s., and in half calf, richly gilt, 305 . or 12 volumes in 6 , Roxburghe, 2Is., and half red morocco, $28 \mathrm{~s}$. Tales from Blackwood. New Series. Complete in Twentyfour Shilling Parts. Handsomely bound in 12 vols., cloth, 30 s. In leather back, Roxburghe style, $37 \mathrm{~s} .6 \mathrm{~d}$. In half calf, gilt, $52 \mathrm{~s} .6 \mathrm{~d}$. In half morocco, $55 \mathrm{~s}$.

Standard Novels. Uniform in size and legibly Printed. Each Novel complete in one volume.

Florin Series, Illustrated Boards.

Tom Cringle's Log. By Michael Scott. $\quad$ Pen Owen. By Dean Hook.

The Cruise of the Midge. By the Same. Adam Blair. By J. G. Lockhart.

Cyril Thornton. By Captain Hamilton. Lady LeE's Widowhood. By General

AnNals of the Parish. By John Galt.

The Provost, \&c. By Johu Galt.

Sir ANDREw Wyite. By John Galt.

The EntarL. By John Galt.

Miss Molly. By Beatrice May Butt. Sir E. B. Hamley.

Salem Chapel. By Mrs Oliphant.

The Perpetual Curate. By Mrs Oliphant.

Miss Maruoribanks. By Mrs Oliphant.
John: A Love Story. By Mrs Oliphant. Or in Cloth Boards, 2s. $6 \mathrm{~d}$.

Shilling Series, Illustrated Cover.

The Rector, and The Doctor's Family. Sir Frizzle Pumpkin, Nights at Mess, By Mrs Oliphant.

The Lire of Mansie Wauch. By D. M. Moir.

Peninsular Scenes and Sketches. By \&c.

The Subaltern.

Life in the FAR WhSt. By G. F. Ruxton.

VALERIUS: A Roman Story. By J. G. Lockhart.

F. Hardman.

Or in Cloth Boards, is. $6 \mathrm{~d}$. 
BLACKMORE. The Maid of Sker. By R. D. Buackmone, Author of ' Lorna Doone,' \&c. Eighth Edition. Crown 8vo, 78. 6d.

BOSCOBEL TRACTS. Relating to the Escape of Charles the Second after the Battle of Worcester, and his subsequent Adventures. Edited by J. HuGHEs, Esq., A.M. A New Edition, with additional Notes and Illus. trations, including Communications from the Rev. R. H. BARHAM, Author of the 'Ingoldsby Legends.' 8v0, with Engravings, 168.

BRACKENBURY. A Narrative of the Ashanti War. Prepared from the official documents, by permission of Major-General Sir Garnet Wolseley, K.C.B., K.C.M.G. By Major H. BrackenbURY, R.A., Assistant Military Secretary to Sir Garnet Wolseley. With Maps from the latest Surveys made by the Staff of the Expedition. 2 vols. 8vo, 25 s.

BROADlEY. Tunis, Past and Present. By A. M. Broadley. With numerous Illustrations and Maps. 2 vols. post 8vo. [In the Press.

BROOKE, Life of Sir James, Rajah of Sarāwak. From his Personal Papers and Correspondence. By Spenser St JoHN, H.M.'s Minister-Resident and Consul-General Peruvian Republic; formerly Secretary to the Rajah. With Portrait and a Map. Post 8vo, 12s. 6d.

BROUGHAM. Memoirs of the Life and Times of Henry Lord Brougham. Written by Hrasselr. 3 vols. $8 v^{\circ}, £_{2}, 8 \mathrm{~s}$. The Volumes are sold separately, price 16 s. each.

BROWN. The Forester: A Practical Treatise on the Planting, Rearing, and General Management of Forest-trees. By JAMES Brown, WoodSurveyor and Nurseryman. Fifth Edition, revised and enlarged. Royal 8vo, with Engravings.

BROWN. The Ethics of George Eliot's Works. By Joнn Crombie Brown. Third Edition. Crown 8vo, 2s. 6d.

BROWN. A Manual of Botany, Anatomical and Physiological. For the Use of Students. By RoBErt Brown, M.A., Ph.D., F.L.S., F.R.G.S. Crown 8vo, with numerous Illustrations, 228 . 6d.

BUCHAN. Introductory Text-Book of Meteorology. By AlExANDER Buchan, M.A., F.R.S.E., Secretary of the Scottish Meteorological Society, \&c. Crown 8vo, with 8 Coloured Charts and other Engravings, pp. 218 . 4 s. $6 \mathrm{~d}$.

BURBIDGE. Domestic Floriculture, Window Gardening, and Floral Decorations. Being practical directions for the Propagation, Culture, and Arrangement of Plants and Flowers as Domestic Ornaments. By F. W. BURBidae. Second Edition. Crown 8vo, with numerous Illustrations, 7s. 6d.

Cultivated Plants: Their Propagation and Improvement. Including Natural and Artifcial Hybridisation, Raising from Seed, Cuttings, and Layers, Grafting and Budding, as applied to the Families and Genera in Cultivation. Crown 8vo, with numerous Illustrations, 12s. $6 \mathrm{~d}$.

BURN. Handbook of the Mechanical Arts Concerned in the Construction and Arrangement of Dwelling-Houses and other Buildings; with Practical Hints on Road-making and the Enclosing of Land. By ROBERT SCOTT Burs, Engineer. Second Editiun. Crown 8vo, 6s. 6d.

BUR'TON. The History of Scotland : From Agricola's Invasion to the Extinction of the last Jacobite Insurrection. By JoHN HILl BURTon, D.C.L., Historiographer-Royal for Scotland. New and Enlarged Edition, 8 vols., and Index. Crown 8 vo, $£_{3}, 35$.

History of the British Empire during the Reign of Queen Anne. In 3 vols. 8 vo. $36 \mathrm{~s}$.

The Cairngorm Mountains. Crown 8vo, 3s. $6 \mathrm{~d}$.

The Scot Abroad. Second Edition. Complete in One volume. Orown 8vo, ros. 6d.

The Book-Hunter. A New and Choice Edition. With a Memoir of the Anthor, a Portrait etched by Mr Hole, A.R.S.A., and other Illustrations. In small 4 to, on hand-made paper.

[In the Press. 
BUTE. The Roman Breviary: Reformed by Order of the Holy Ecumenical Council of Trent; Published by Order of Pope St Pius V.; and Revised by Clement VIII. and Urban VIII.; together with the Offices since granted. Translated out of Latin into English by JoHs, Marquess of Bute, K.T. In 2 vols. crown 8 vo, cloth boards, edges uncut. $£ 2,2 \mathrm{~s}$.

The Altus of St Columba. With a Prose Paraphrase and Notes. In paper cover, $2 \mathrm{~s} .6 \mathrm{~d}$.

BUTT. Miss Molly. By Beatrice Mar Butr. Cheap Edition, 2s.

- Delicia. By the Author of 'Miss Molly.' Fourth Edition. Crown 8vo, 7s. 6d.

CAIRD. Sermons. By JoHn CAIRD, D.D., Principal of the University of Glasgow. Fourteenth Thousand. Fcap. 8vo, 58 .

Religion in Common Life. A Sermon preached in Crathie Church, October 14,1855 , before Her Majesty the Queen and Prince Albert. Published by Her Majesty's Command Cheap Edition, 3d.

CAMPBELL, Life of Colin, Lord Clyde. See General Shadweld, at page 20.

CAMPBELL. Sermons Preached before the Queen at Balmoral. By the Rev. A. A. CAMpbelL, Minister of Crathie. Published by Command of Her Majesty. Crown 8vo, 4s. $6 \mathrm{~d}$.

CARLYLE. Autobiography of the Rev. Dr Alexander Carlyle, Minister of Inveresk. Containing Memorials of the Men and Events of his Time. Edited by John Hill BurTon, 8vo. Third Edition, with Portrait, 14s.

CARRICK. Koumiss ; or, Fermented Mare's Milk : and its Uses in the Treatment and Cure of Pulmonary Consumption, and other Wasting Diseases. With an Appendix on the best Methods of Fermenting Cow's Milk. By Georae L. Carrick, M.D., L.R.C.S.E. and L.R.C.P.E., Physician to the British Embassy, St Petersburg, \&c. Crown 8vo, ros. 6d.

CAUVIN. A Treasury of the English and German Languages. Compiled from the best Authors and Lexicographers in both Languages. Adapted to the Use of Schools, Students, Travellers, and Men of Business; and forning a Companion to all German-English Dietionaries. By JosEPH CAUvin, LL.D. \& Ph.D., of the University of Göttingen, \&c. Crown 8vo, 7s. $6 \mathrm{~d}$.

CAVE-BROWN. Lambeth Palace and its Associations. By J. CAVE-BRown, M.A., Vicar of Detling, Kent, and for many years Curate of Lambeth Parish Church. With an Introduction by the Archbishop of Canterbury. In One volume, with Illustrations.

[In the Press.

CHARTERIS. Canonicity; or, Early Testimonies to the Existence and Use of the Books of the New Testament. Based on Kirchhoffer's 'Quellensanimlung.' Edited by A. H. Charteris, D.D., Professor of Biblical Criticism in the University of Edinburgh. 8 vo, 18s.

Life of the Rev. James Robertson, D.D., F.R.S.E., Professor of Divinity and Ecclesiastical History in the University of Edinburgh. By Professor Charteris. With Portrait. 8vo, ros. 6d.

CHEVELEY NOVELS, THE.

I. A MODERN Minister. 2 vols. bound in cloth, with Twenty-six Illustrations.

II. SAUL WeIR. 2 vols. bound in cloth. With Twelve Illustrations by F. Barnard. $16 \mathrm{~s}$.

CHIROL. 'Twixt Greek and Turk. By M. Valentine Chirol. Post 8vo. With Frontispiece and Map, ros. 6d.

CHURCH SERVICE SOCIETY. A Book of Common Order : Being Forms of Worship issued by the Church Service Society. Fourth Edition, $5 \mathrm{~s}$. 
COLQUHOUN. The Moor and the Loch. Containing Minute Instructions in all Highland Sports, with Wanderings over Crag and Corrie, Flood and Fell. By JoHN ColquHoux. Fifth Edition, greatly enlarged. With Illustrations. 2 vols. post $8 \mathrm{vo}, 26 \mathrm{~s}$.

COTTERILL. The Genesis of the Church. By the Right. Rer. HenRy Cotrerilu, D.D., Bishop of Edinburgh. Demy 8vo, I6s.

CRANSTOUN. The Elegies of Albius Tibullus. Translated into English Verse, with Life of the Poet, and Illustrative Notes. By JAMEs CraNsTOUN, LL.D., Author of a Translation of 'Catullus.' Crown 8vo, 6s. 6d.

The Elegies of Sextus Propertius. Translated into English Verse, with Life of the Poet, and Illustrative Notes. Crown 8vo, 7s. 6d.

CRAWFORD. The Doctrine of Holy Scripture respecting the Atonement. By the late Thomas J. Crawford, D.D., Professor of Divinity in the University of Edinburgh. Third Edition. 8vo, 128.

The Fatherhood of God, Considered in its General and Special Aspects, and particularly in relation to the Atonement, with a Review of Recent Speculations on the Subject. Third Edition, Revised and Enlarged. 8vo, 9 s.

The Preaching of the Cross, and other Sermons. 8vo, 78. $6 \mathrm{~d}$.

The Mysteries of Christianity; being the Baird Lecture for 1874. Crown 8vo, 7s. 6d.

CROSSE. Round about the Carpathians. By Andrew F. Crosse, F.C.S. 8vo, with Map of the Author's route, price 12s. 6d.

DESCARTES. The Method, Meditations, and Principles of Philosophy of Descartes. Translated from the Original French and Latin. With a New Introductory Essay, Historical and Critical, on the Cartesian Philosophy. By JoHN VerTCH, LL. D., Professor of Logic and Rhetoric in the University of Glasgow. A New Edition, being the Eighth. Price 6s. 6d.

DICKSON. Japan; being a Sketch of the History, Government, and Officers of the Empire. By WaLter Dickson. 8vo, $15 \mathrm{~s}$.

DU CANE. The Odyssey of Homer, Books I.-XII. Translated into English Verse. By Sir Charles Du Cane, K.C.M.G. 8vo, ros. 6d.

DUDGEON. History of the Edinburgh or Queen's Regiment Light Infantry Militia, now Third Battalion, The Royal Scots; with an Account of the Origin and Progress of the Militia, and a Brief Sketch of the old Royal Scots. By Major R. C. DuDaEon, Adjutant 3d Battalion The Royal Scots. Post $8 \mathrm{vo}$, with Illustrations, ros. 6 d.

EAGLES. Essays. By the Rev. John Eagles, A.M. Oxon. Originally published in 'Blackwood's Magazine.' Post 8vo, ros. $6 \mathrm{~d}$.

The Sketcher. Originally published in 'Blackwood's Magazine.' Post 8vo, 1os. 6d.

ELIOT. Impressions of Theophrastus Such. By GeORgE Eliot. New and cheaper Edition. Crown 8vo, 5 s.

Adam.Bede. Illustrated Edition. 3s. 6d, cloth.

The Mill on the Floss. Illustrated Edition. 3s. 6d., cloth. Scenes of Clerical Life. Illustrated Edition. 3s., cloth.

Silas Marner: The Weaver of Raveloe. Illustrated Edition. 2s. 6d., eloth.

Felix Holt, the Radical. Illustrated Edition. 3s.6d., cloth.

Romola. With Vignette. 3s. 6d., cloth.

Middlemarch. Crown 8vo, 7s. 6d.

- Daniel Deronda. Crown 8vo, 7s. 6d. 


\section{WILLIAM BLACKWOOD AND SONS.}

ELIOT. Works of George Eliot (Cabinet Edition). Complete and Uniform Edition, handsomely printed in a new type, 20 volumes, crown 8vo, price $6_{55}$. The Volumes are also sold separately, price 58. e2ch, viz. :-

Romola. 2 vols. - Silas Marner, The Lifted Veil, Brother Jacob. I vol Adam Bede. 2 vols. - Scenes of Clerical Life. 2 vols. -The Mill on the Floss. 2 vols.-Felix Holt. 2 vols. - Middlemarch. 3 vols. Daniel Deronda. 3 vols.-The Spanish Gypsy. I vol.-Jubal, and other Poems, Old and New. I vol.-Theophrastus Such. I vol.

- The Spanish Gypsy. Crown 8vo, $5 \mathrm{~s}$.

The Legend of Jubal, and other Poems, Old and New. New Edition. Fcap. 8vo, 5s., cloth.

Wise, Witty, and Tender Sayings, in Prose and Verse. Selected from the Works of GEORGe Eliot. Fifth Edition. Fcap. 8vo, 6s.

The George Eliot Birthday Book. Printed on fine paper, with red border, and handsomely bound in cloth, gilt. Fcap. 8vo, cloth, 3s. 6d. And in French morocco or Russia, $5 \mathrm{~s}$.

ESSAYS ON SOCIAL SUBJECTS. Originally published in the 'Saturday Review.' A New Edition. First and Second Series. 2 vols. crown 8vo, 6s. each.

EWALD. The Crown and its Advisers ; or, Queen, Ministers, Lords, and Commons. By Alexander Charles Ewald, F.S.A. Crown 8vo, ${ }^{5} \mathrm{~s}$.

THE FAITHS OF THE WORLD. A Concise History of the Great Religious Systems of the World. By various Authors. Being the St Giles' Lectures-Second Series. Complete in One Volume, Crown 8vo, $5 \mathrm{~s}$. Sold separately, price $4 \mathrm{~d}$.

FERGUSSON. The Honourable Henry Erskine, Lord Advocate for Scotland. With Notices of certain of his Kinsfolks and of his Time Compiled from Family Papers, and other sources of Information. By. LievTenant-Colonel Alex. Fergusson, late of the Staff of her. Majesty's Indian Army. In One volume, large 8vo. With Portraits and other Illustrations.
[Shortly.

FERRIER. Philosophical Works of the late James F. Ferrier, B.A. Oxon., Professor of Moral Philosophy and Political Economy, St Andrews. New Edition. Edited by Sir ALEX. GRANT, Bart., D.C.L., and Professor LUSHINGTON. 3 vols, crown 8 vo, 34s. $6 \mathrm{~d}$.

_ Institutes of Metaphysic. Third Edition. Ios. $6 \mathrm{~d}$.

Lectures on the Early Greek Philosophy. Third Edition. ros. 6 d.

- Philosophical Remains, including the Lectures on Early Greek Philosophy. 2 vols., 24s.

FERRIER. George Eliot and Judaism. An Attenıt to appreciate 'Daniel Deronda.' By Professor David Kaufmann, of the Jewish Theological Seminary, Buda-Pesth. Translated from the German by J. W. FERrier. Second Edition. Crown 8vo, 2s. 6d.

FLINT. The Philosophy of History in Europe. Vol. I., containing the History of that Philosophy in France and Germany. By ROBERT FLinT, D.D., LL.D., Professor of Divinity, University of Edinburgh. 8vo, ${ }_{5} \mathrm{~s}$.

Theism. Being the Baird Lecture for 1876. Third Edition. Crown 8vo, 7s. 6d.

Anti-Theistic Theories. Being the Baird Lecture for 1877 . Second Edition. Crown 8vo, ros. 6 d.

FORBES. The Campaign of Garibaldi in the Two Sicilies : A Personal Narrative. By CHarles StUART Forbes, Commander, R.N. Post 8vo; with Portraits, r2s. 
FOREIGN CLASSICS FOR ENGLISH READERS. Edited by Mrs Oliphant. Price 2s. 6 d.

\section{Now published :-}

Dante. By the Editor.
Voltaire. By General Sir E. B. Hamley,

K.C.M.G.

PASCAL By Principal Tulloch.

Petrarch. By Henry Reeve, C.B.

GoEthe. By A. Hayward, Q.C.

Molizere. By the Editor and F. Tarver, M.A.

Montaigne. By Rev. W. L. Collins, M.A.

RABELAIS. By Walter Besant, M.A.

Calderon. By E. J. Hasell. Sarnt Simon. By Clifton W. Collins,
M.A.

Cervantes. By the Editor.

Corneille and Racine. By Henry M. Trollope.

Madame de SÉvigné. By Miss Thackeray.

La Fontaine, and other French FabULists. By Rev. W. L. Collins, M.A.

Schiller. By James Sime, M.A., Author of 'Lessing: his Life and Writings.'

In preparation :-Rousseav. By Henry Graham.-TAsso. By E. J. Hasell.

FRASER. Handy Book of Ornamental Conifers, and of Rhododendrons and other American Flowering Shrubs, suitable for the Climate and Soils of Britain. With descriptions of the best kinds, and containing Useful Hints for their successful Cultivation. By HUGH FrASER, Fellow of the Botanical Society of Edinburgh. Crown 8vo, 6s.

GaLT. Annals of the Parish. By JoHn Galt. Fcap. 8vo, 2s.

The Provost. Fcap. 8vo, 2s.

Sir Andrew Wylie. Fcap. 8vo, $2 \mathrm{~s}$.

The Entail ; or, The Laird of Grippy. Fcap. 8vo, 2s.

GARDENER, THE : A Magazine of Horticulture and Floriculture. Edited by David Thomson, Author of 'The Handy Book of the Flower-Garden,' \&c..; Assisted by a Staff of the best practical Writers. Published Monthly, 6 d.

GENERAL ASSEMBLY OF THE CHURCH OF SCOTLAND. Family Prayers. Authorised by the General Assembly of the Church of Scotiand. A New Edition, crown 8vo, in large type, 4s. 6d. Another Edition, crown 8vo, 28.

Prayers for Social and Family Worship. For the Use of Soldiers, Sailors, Colonists, and Sojourners in India, and other Persons, at home and abroad, who are deprived of the ordinary services of a Christian Ministry. Cheap Edition, Is. 6 d.

The Scottish Hymnal. Hymns for Public Worship. Published for Use in Churches by Authority of the General Assembly. Various sizes-viz. : I. Large type, for pulpit use, cloth, 3s. 6d. 2. Longprimer type, cloth, red edges, Is. 6d. ; French morocco, 28. 6d. ; calf, 6s. 3. Bourgeois type, cloth, red edges, rs. ; French morocco, $2 \mathrm{~s}$. 4. Minion type, limp cloth, 6d.; French morocco, Is. 6d. 5. Schoul Edition, in paper cover, 2d. 6. Children's Hymnal, paper cover, Id. No. 2, bound with the Psalms and Paraphrases, cloth, $3 \mathrm{~s}$.; French morocco, $4 \mathrm{~s} .6 \mathrm{~d}$.; calf, $7 \mathrm{~s}$. $6 \mathrm{~d}$. No. 3 , wound with the Psalms and Paraphrases, cloth, 2s. ; French morocco, $3 \mathrm{~s}$.

The Scottish Hymnal, with Music. Selected by the Committees on Hymns and on Psalmody. The harmonies arranged by W. H. Monk. Cloth, 1s. 6d. ; French morocco, 3s. 6d. The same in the Tunic Sol-fa Notation, Is. $6 \mathrm{~d}$. and 3 s. $6 \mathrm{~d}$.

The Scottish Hymnal, with Fixed Tune for each Hymn. Longprimer type, 3s. 6d.

GERARD. Reata: What's in a Name? By E. D. Gerard. New Edition. In one volume, crown $8 \mathrm{vo}, 6 \mathrm{~s}$.

Beggar my Neighbour. A Novel. New Edition, complete in one volume, crown $8 \mathrm{vo}, 6 \mathrm{~s}$. 
WILLIAM BLACKWOOD AND SONS.

GLEIG. The Subaltern. By G. R. Gleig, M.A., late ChaplainGeneral of Her Majesty's Forces. Originally published in 'Blackwood's Magazine.' Library Edition. Revised and Corrected, with a New Preface. Crown 8vo, 7s. 6d.

GOETHE'S FAUST. . Translated into English Verse by Sir TheoDORE MIARTIN, K.C.B. Second Edition, post 8vo, 6s. Cheap Edition, fcap., 3s. 6 d.

- Poems and Ballads of Goethe. Translated by Professor Aytoun and Sir Theodore MARTin, K.C.B. Third Edition, fcap. 8vo, 6s.

GORDON CUMMING. At Home in Fiji. By C. F. Gordon Cumming, Author of 'From the Hebrides to the Hinalayas.' Fourth Edition, complete in one volume post 8vo. With Illustrations and Map. $7 \mathrm{s.} 6 \mathrm{~d}$.

- A Lady's Cruise in a French Man-of-War. New and Cheaper Edition. In one volume, 8vo. With Illustrations and Map. 128.6d.

GRAHAM. Annals and Correspondence of the Viscount and First and Second Earls of Stair. By John Murray Grahas. 2 vols. demy 8vo, with Portraits and other Illustrations. $£_{1}, 8 \mathrm{~s}$.

- Memoir of Lord Lynedoch. Second Edition, crown 8vo, $5 \mathrm{~s}$.

GRANT. Bush-Life in Queensland. By A. C. Grant. New Edition In One volume crown 8 vo, $6 \mathrm{~s}$.

GRANT. Incidents in the Sepoy War of i 857-58. Compiled from the Private Journals of the late General Sir HoPE GRANT, G.C.B. ; together with some Explanatory Chapters by Captain HENRx KNoLlys, R.A. Crown 8vo, with Map and Plans, 12s.

GRANT. Memorials of the Castle of Edinburgh. By JAMES Grant. A New Edition. Crown 8vo, with 12 Engravings, 2s.

HAMERTON. Wenderholme : A Story of Lancashire and Yorkshire Life. By Philip Gilbert Hamerton, Author of 'A Painter's Camp.' A New Edition. Crown 8vo, 6s.

HAMILTON. Lectures on Metaphysics. By Sir William HamilTON, Bart., Professor of Logic and Metaphysics in the University of Edinburgh. Edited by the Rev. H. L. Mansel, B.D., LL.D., Dean of St Paul's; and JoHN VEITCH, M. A., Professor of Logic and Rhetoric, Glasgow. Sixth Edition. 2 vols. 8 vo, $24 \mathrm{~s}$.

Lectures on Logic. Edited by the SAME. Third Edition. 2 vols. 24 s.

Discussions on Philosophy and Literature, Education and University Reform. Third Edition, 8vo, 21s.

Memoir of Sir William Hamilton, Bart., Professor of Logic and Metaphysics in the University of Edinburgh. By Professor VeitcH of the University of Glasgow. 8vo, with Portrait, $18 \mathrm{~s}$.

HAMILTON. Annals of the Peninsular Campaigns. By Captain Thomas Hamilton. Edited by F. Hardman. 8vo, x6s. Atlas of Maps to illustrate the Campaigns, $12 \mathrm{~s}$.

HAMLEY. The Operations of War Explained and Illustrated. By General Sir EDWARD BRUCE HAMLEY, K.C.M.G. Fourth Edition, revised throughout. 4to, with numerous Illustrations, 30 s.

Thomas Carlyle: An Essay. Second Edition. Crown 8vo. 2s. 6d.

The Story of the Campaign of Sebastopol. Written in the Camp. With Illustrations drawn in Camp by the Author. 8vo, 2rs.

On Outposts. Second Edition. 8vo, $2 \mathrm{~s}$.

Wellington's Career; A Military and Political Summary. Crown 8vo, 2s.

— Lady Lee's Widowhood. Crown 8vo, 2s. 6 d. 
HAMLEY. Our Poor Relations. A Philozoic Essay. With Illustrations, chiefly by Ernest Griset. Crown 8vo, cloth gilt, 3s. 6d.

HAMLEY. Guilty, or Not Guilty? A Tale. By Major-General W. G. HAMLEX, late of the Royal Engineers. New Edition. Crown 8vo, 3s. 6d. The House of Lys : One Book of its History. A Tale. Second Edition. 2 vols. crown 8vo. $17 \mathrm{~s}$.

Traseaden Hall. "When George the Third was King." 3 vols., post 8 vo, 25 s. 6 d.

HANDY HORSE-BOOK; or, Practical Instructions in Riding, Driving, and the General Care and Management of Horses. By 'MAGENTA.' Ninth Edition, with 6 Engravings, 4s. 6d.

\section{By the Same.}

Our Domesticated Dogs: their Treatment in reference to Food, Diseases, Habits, Punishment, Accomplishments. Crown 8vo, 2s. 6d.

HARBORD. Definitions and Diagrams in Astronomy and Navigation. By the Rev. J. B. HARBord, M.A., Assistant Director of Education, Admiralty. xs.

Short Sermons for Hospitals and Sick Seamen. Fcap. 8vo, cloth, 4s. 6d.

HARDMAN. Scenes and Adventures in Central America. Edited by FredertcK HARDMAN. Crown 8vo, $6 \mathrm{~s}$.

HAWKEY. The Shakespeare Tapestry. Woven in Verse. By C. HAWKEY. Fcap. 8vo. 6s.

HAY. The Works of the Right Rev. Dr George Hay, Bishop of Edinburgh. Edited under the Supervision of the Right Rev. Bishop STraix. With Memoir and Portrait of the Author. 5 vols. crown 8vo, bound in extra cloth, $£ x$, is. Or, sold separately-viz.:

The Sincere Christian Instructed in the Faith of Christ from the Written Word. 2 vols., $8 \mathrm{~s}$.

The Devout Christian Instructed in the Law of Christ from the Written Word. 2 vols., $8 \mathrm{~s}$.

The Pious Christian Instructed in the Nature and Practice of the Principal Exercises of Piety. I vol., 4s.

HEATLEY. The Horse-Owner's Safeguard. A Handv Medical Guide for every Man who owns a Horse. By G. S. Heatuey, V.S In one volume, crown 8 vo.
[In the Press.

HEMANS. The Poetical Works of Mrs Hemans. Copyright Editions.

One Volume, royal 8vo, $5 \mathrm{~s}$.

The Same, with Illustrations engraved on Steel, bound in cloth, gilt edges, 7 s. $6 \mathrm{~d}$.

Six Volumes in Three, fcap., 128. 6 d.

Select Poems of Mrs Hzmans. Fcap., cloth, gilt edges, 38. Memoir of Mrs Hemans. By her Sister. With a Portrait, fcap. $8 \mathrm{vo}, 5 \mathrm{~s}$.

HOLE. A Book about Roses: How to Grow and Show Them. By the Rev. Canon HoLE. With coloured Frontispiece by the Hon. Mrs Francklin. Seventh Edition, revised. Crown 8vo, 7s. 6d.

HOMER. The Odyssey. Translated into English Verse in the Spenserian Stanza. By Philip Stanhope Worslex. Third Edition, 2 vols., feap., r2s.

The Iliad. Translated by P. S. Worslex and Professor Coninaton. 2 vols. crown 8vo, 2 rs. 
HOME PRAYERS. By Ministers of the Church of Scotland and Members of the Church Service Society. Fcap. 8vo, price $3 \mathrm{~s}$.

HOSACK. Mary Queen of Scots and Her Accusers. Containing a Variety of Documents never before published. Вy ЈонN HоsАCK, Barristerat-Law. A New and Enlarged Edition, with a Photograph from the Bust on the Tomb in Westmiuster Abbey. 2 vols. 8vo, $\mathrm{E}_{\mathrm{r}}, \mathrm{xs}$.

INDEX GEOGRAPHICUS : Being a List, alphabetically arranged, of the Principal Places on the Globe, with the Countries and Subdivisions of the Countries in which they are situated, and their Latitudes and Longitudes. Applicable to all Modern Atlases and Maps. Imperial 8vo, pp. 676, 2is.

JAMIESON. The Laird's Secret. By J. H. JAMIESon. In 2 vols., crown 8 vo.

JEAN JAMBON. Our Trip to Blunderland ; or, Grand Excursion to Blundertown and Back. By JEAN JAMBON. With Sixty Illustrations designed by Charles Doyle, engraved by Dalziel. Fourth Thousand. Handsomely bound in cloth, gilt edges, 6s. 6d. Cheap Edition, cloth, 3s. 6d. In boards, 28. $6 \mathrm{~d}$.

JOHNSON. The Scots Musical Museum. Consisting of upwards of Six Hundred Songs, with proper Basses for the Pianoforte. Originally published by JAMES JOHNSON; and now accompanied with Copious Notes and Illustrations of the Lyric Poetry and Music of Scotland, by the late WILLIAM STENhouse; with additional Notes and Illustrations, by DAVID LaING and C. K. SHARPE. 4 vols. 8vo, Roxburghe binding, £2, r2s. $6 \mathrm{~d}$.

JOHNSTON. The Chemistry of Common Life. By Professor J. F. W. Johnston. New Edition, Revised, and brought down to date. By ARTHUR HERBERT ChURCH, M.A. Oxon.; A A thor of 'Food: its Sources, Constituents, and Uses;' 'The Jabooratory Guide for Agricultural Students :' 'Plain Words about Water,' \&c. Illustrated with Maps and ro2 Engravings on Wood. Complete in One Volume, crown 8vo, pp. $618,7 \mathrm{~s} .6 \mathrm{~d}$.

Professor Johnston's Elements of Agricultural Chemistry and Geology. Twelfth Edition, Revised, and brought down to date. By Charles A. Cameron, M.D., F.R.C.S.I., \&c. Fcap. 8vo. 6s. 6d.

Catechism of Agricultural Chemistry and Geology. An entirely New Edition, revised and enlarged, by Charles A. Cameron, M.D., F.R.C.S. I. , \&c. Eighty-first Thousand, with numerous Illnstrations, Is.

JOHNSTON. Patrick Hamilton : a Tragedy of the Reformation in Scotland, 1528. By J. P. Johnston. Crown 8vo, with Two Etchings by the Author, $5 \mathrm{~s}$.

KEITH ELPHINSTONE. Memoir of the Honourable George Keith Elphinstone, K.B., Viscount Keith of Stonehaven Marischal, Admiral of the Red.-See ALEXANDER ALLARDYCE, at page 4.

KING. The Metamorphoses of Ovid. Translated in English Blank Verse. By Henry King, M.A., Fellow of Wadham. College, Oxford, and of the Inner Temple, Barrister-at-Law. Crown 8vo, ros. 6d.

KINGLAKE. History of the Invasion of the Crimea. By A. W. Kinglake. Cabinet Edition. Six Volumes, crown 8vo, at 6s. each. The Volumes respectively contain :-

I. The Origin of The WAR between the Czar and the Sultan.

II. Russia Met and Invaded. With 4 Maps and Plans.

III. The BatTle of the Alma. With 14 Maps and Plans.

IV. SeBastopol at Bay. With ro Maps and Plans.

V. The Battle of Balaclava. With ro Maps and Plans.

Vi. The BatTLe of INKerman. With II Maps and Plans.

VII. WINTER TROUBLES. With Map.

[In the Press.

History of the Invasion of the Crimea. Vol. VI. Winter Troubles. Demy 8vo, with a Map, r6s.

Eothen. A New Edition, uniform with the Cabinet Edition of the 'History of the Crimean War,' price 6s. 
KNOLLYS. The Elements of Field-Artillery. Designed for the Use of Infantry and Cavalry Officers. By HenRY Knollys, Captain Royal Artillery; Author of 'From Sedan to Saarbruck,' Editor of 'Incidents in the Sepoy War,' \&c. With Engravings. Crown 8vo, 7 s. 6 d.

LAKEMAN. What I saw in Kaffir-land. By Sir StepheN Lakeman (Mazhar Pacha). Post 8vo, 8s. 6d.

LAVERGNE. The Rural Economy of England, Scotland, and Ireland. By Leonce DE LAvergane. Translated from the French. With Notes by a Scottish Farmer. 8vo, 12S.

LEE. Lectures on the History of the Church of Scotland, from the Reformation to the Revolution Settlement. By the late Very Rev. JoHN LEE, D.D., LL. D., Principal of the University of Edinburgh. With Notes and Appendices from the Author's Papers. Edited by the Rev. WILLIAM LEE, D.D. 2 vols. $8 \mathrm{vo}, 2 \mathrm{Is}$.

LEE-HAMILTON. Poems and Transcripts. By Eugene LeeHamilton. Crown 8vo, $6 \mathrm{~s}$.

LEWES. The Physiology of Common Life. By Georae H. LEWEs, Author of 'Sea-side Studies,' \&c. Illustrated with numerous Engravings. 2 vols., 12s.

LOCKHART. Doubles and Quits. By Laurence W. M. LockHART. With Twelve Illustrations. Third Edition. Crown 8vo, 6s.

Fair to See : a Novel. Seventh Edition, crown 8vo, 6s.

- Mine is Thine : a Novel. Seventh Edition, crown 8vo, 6s.

LORIMER. The Institutes of Law : A Treatise of the Principles of Jurisprudence as determined by Nature. By JAMEs LORIMER, Regius Professor of Public Law and of the Law of Nature and Nations in the University of Edinburgh. New Edition, revised throughont, and nuch enlarged. $8 \mathrm{vo}, \mathrm{x} 8 \mathrm{~s}$.

The Institutes of the Law of Nations. A Treatise of the Jural Relation of Separate Political Communities. 8vo. [In the Press.

LYON. History of the Rise and Progress of Freemasonry in Scotland. By David Murray Lyon, Secretary to the Grand Lodge of Scotland. In small quarto. Illustrated with numerous Portraits of Eininent Members of the Craft, and Facsimiles of Aucient Charters and other Curious Documents. $6 \mathrm{x}, \mathrm{xrs} .6 \mathrm{~d}$.

M'COMBIE. Cattle and Cattle-Breeders. By William M'Combie, Tillyfour. A New and Cheaper Edition, 2s. 6d., cloth.

MACRAE. A Handbook of Deer-Stalking. By Alexander MACRAE, late Forester to Lord Henry Bentinck. With Introduction by Horatio Ross, Esq. Feap. 8vo, with two Photographs from Life. 3s. 6d.

M'CRIE. Works of the Rev. Thomas M'Crie, D.D. Uniform Edition. Four vols. crown $8 \mathrm{vo}, 24 \mathrm{~s}$.

Life of John Knox. Containing Illustrations of the History of the Reformation in Scotland. Crown 8vo, 68. Another Edition, 3s. 6d. Life of Andrew Melville. Containing Illustrations of the Ecclesiastical and Literary History of Scotland in the Sixteenth and Seventeenth Centuries. Crown $8 \mathrm{vo}, 6 \mathrm{~s}$.

History of the Progress and Suppression of the Reformation in Italy in the Sixteenth Century. Crown $8 \mathrm{vo}, 4 \mathrm{~s}$.

History of the Progress and Suppression of the Reformation in Spain in the Sixteenth Century. Crown 8vo, 3s. 6d.

Sermons, and Review of the 'Tales of My Landlord.' Crown $8 \mathrm{vo}, 6 \mathrm{~s}$.

Lectures on the Book of Esther. Fcap. 8vo, 5s. 
M'INTOSH. The Book of the Garden. By Charles M'INTOSH, formerly Curator of the Royal Gardens of his Majesty the King of the Belgians, and lately of those of his Grace the Duke of Buccleuch, K.G., at Dalkeith Palace. Two large vols. royal 8vo, embellished with 1350 Engravings. fo4, 78. 6d.

Vol. I. On the Formation of Gardens and Construction of Garden Edifices. 776 pages, and xo 73 Engravings, E2, xos.

Vol. II. Practical Gardening. 868 pages, and 279 Engravings, $£_{x}, 173.6 \mathrm{~d}$.

MACKAY. A Manual of Modern Geography; Mathematical, Physical, and Political. By the Rev. AlExander MACkAy, LL.D., F.R.G.S. New and Greatly Improved Edition. Crown 8vo, pn. 688. $7 \mathrm{~s}$. $6 \mathrm{~d}$.

Elements of Modern Geography. 47th Thousand, revised to the present time. Crown $8 \mathrm{vo}, \mathrm{pp} .300,3 \mathrm{~s}$.

The Intermediate Geography. Intended as an Intermediate Book between the Author' 'Outlines of Geography,' and 'Elements of Geography.' Eighth Edition, crown 8vo, pp. 224, 2s.

Outlines of Modern Geography. I42d Thousand, revised to the Present Time. $18 \mathrm{mo}, \mathrm{pp}$. II2, is.

First Steps in Geography. $82 \mathrm{~d}$ Thousand. $18 \mathrm{mo}$, pp. 56. Sewed, 4d.; cloth, 6d.

Elements of Physiography and Physical Geography. With Express Reference to the Instructions recently issued by the Science and Art Department. Igth Thousand. Crown 8vo, 18. 6d.

Facts and Dates; or, the Leading Events in Sacred and Profane History, and the Principal Facts in the various Physical Sciences. The Memory being aided throughout by a Simple and Natural Method. For Schools and Private Reference. New Edition, thoroughly Revised. Crown $8 \mathrm{vo}, 3 \mathrm{~s} .6 \mathrm{~d}$.

MACKENZIE. Studies in Roman Law. With Comparative Views of the Laws of France, England, and Scotland. By LoRd MACKEnzie, one of the Judges of the Court of Session in Scotland. Fifth Edition, Edited by John KIRKPATrick, Esq., M.A. Cantab. ; Dr Jur. Heidelb.; LI.B., Edin.; Advocate. 8vo, x2s.

MANNERS. Notes of an Irish Tour in 1846. By Lord JoHN Manners, M.P., G.C.B. New Edition, crown 8vo. 2s. 6 d.

MARMORNE. The Story is told by ADolphos SEgrave, the youngest of three Brothers. Third Edition. Crown 8vo, 6s.

MARSHALL. French Home Life. By Frederic Marshall,

Contents: Servants. - Children. - Furniture.-Food. - Manners. - Language.-Dress.-Marriage. Second Edition. $5 \mathrm{~s}$.

MARSHMAN. History of India. From the Earliest Period to the Close of the India Company's Government; with an Epitome of Subsequent Events. By John Clark Marshman, C.S.I. Abridged from the Author's larger work. Second Edition, revised.' Crown 8vo, with Map, 6s. 6d.

MARTIN. Goethe's Faust. Translated by Sir Theodore Martin, K.C.B. Second Edition, erown 8vo, 6s. Cheap Edition, 3s. 6d.

The Works of Horace. Translated into English Verse, with Life and Notes. In 2 vols. crown $8 \mathrm{vo}$, printed on hand-made paper, 2Is.

Poems and Ballads of Heinrich Heine. Done into English Verse. Second Edition. Printed on papier vergé, crown $8 \mathrm{vo}, 8 \mathrm{~s}$.

Catullus. With Life and Notes. Second Edition, post 8vo, 75. 6 d.

The Vita Nuova of Dante. With an Introduction and Notes. Second Edition, crown 8vo, 5s.

Aladdin: A Dramatic Poem. By Adam Oenlenschlaeger. Fcap. 8vo, 5s. 
MartiN. Correggio: A Tragedy. By Oehlenschlaeger. With Notes. Fcap. 8vo, 38 King Rene's Daughter: A Danish Lyrical Drama. By HENRIK Hertz. Second Edition, fcap., 2s. 6d.

MEIKLEJOHN. An Old Educational Reformer-Dr Bell. By J. M. D. Meiklejohn, M.A., Professor of the Theory, History, and Practice of Education in the University of St Andrews. Crown 8vo, 3s. 6d.

MICHEL. A Critical Inquiry into the Scottish Language. With the view of Illustrating the Rise and Progress of Civilisation in Scotland. By FrancisQUe-Michel, F.S.A. Lond. and Seot., Correspondant de l'Institut de France, \&c. In One handsome Quarto Volume, printed on hand-made paper, and appropriately bound in Roxburghe style. Price 66s. The Edition is strictly limited to 500 copies, which will be numbered and allotted in the order of application.

MICHIE. The Larch : Being a Practical Treatise on its Culture and General Management. By Christopher Young Michie, Forester, Cullen House. Crown 8vo, with Illustrations. 78. 6d.

MINTO. A Manual of English Prose Literature, Biographical and Critical : designed mainly to show Characteristics of Style. By W. MrNTo, M.A., Professor of Logic in the University of Aberdeen. Second Edition, revised. Crown 8vo, 7s. $6 \mathrm{~d}$.

Characteristics of English Poets, from Chaucer to Shirley. Crown 8vo, $9 \mathrm{~s}$.

MITCHELL. Biographies of Eminent Soldiers of the last Four Centuries. By Major-General Joнn Mrtcheld, Author of 'Life of Wallenstein,' With a Memoir of the Author. 8vo, gs.

MOIR. Poetical Works of D. M. Morr (Delta). With Memoir by Thomas AIRD, and Portrait. Second Edition, 2 vols. fcap. 8vo, r2s.

Domestic Verses. New Edition, fcap. 8vo, cloth gilt, 4s. 6d.

Lectures on the Poetical Literature of the Past Half-Century. Third Edition, fcap. 8vo, $5 \mathrm{~s}$.

Life of Mansie Wauch, Tailor in Dalkeith. With 8 Illustrations on Steel, by the late Georoz Croikshaxk. Crown 8vo. 3s. 6d. Another Edition, fcap. 8vo, rs. 6 d.

MOMERIE. The Origin of Evil ; and other Sermons. Preached in St Peter's, Cranley Gardens. By the Rev. A. W. Momerie, M.A., D.Sc., Fellow of St John's College, Cambridge; Professor of Logic and Metaphysics in King's College, London. Second Edition, enlarged. Crown 8vo, $5 \mathrm{~s}$.

Personality. The Beginning and End of Metaphysics, and the Necessary Assumption in all Positive Philosophy. Crown 8vo, $3^{s}$.

MONTAGUE. Campaigning in South Africa. Reminiscences of

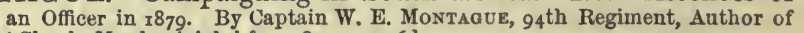
'Claude Meadowleigh,' \&c. 8vo, ros. 6 d.

MONTALEMBERT. Count de Montalembert's History of the Monks of the West. From St Benedict to St Bernard. Translated by Mrs OLIPHANT. 7 vols. $8 \mathrm{vo}, €_{3}, 178.6 \mathrm{~d}$.

Memoir of Count de Montalembert. A Chapter of Recent French History. By Mrs OLiphant, Author of the 'Life of Edward Irving,' \&c. 2 vols. crown 8 vo. $6 \mathrm{I}, 4 \mathrm{~s}$.

MORE THAN KIN. By M. P. One volume, crown 8vo, 7s. 6d.

MURDOCH. Manual of the Law of Insolvency and Bankruptcy : Comprehending a Summary of the Law of Insolvency, Notour Bankruptcy, Composition-contracts, Trust-deeds, Cessios, and Sequestrations; and the Winding-up of Joint-Stock Companies in Scotland; with Annotations on the various Insolvency and Bankruptcy Statutes; and with Forms of Procedure applicable to these Subjects. By JAMEs MURDoch, Member of the Faculty of Procurators in Glasgow. Fourth Edition, Revised and Enlarged, 8vo, £ I. 
NEAVES. A Glance at some of the Principles of Comparative Philology. As illustrated in the Latin and Anglican Forms of Speech. By the Hon. Lord Neaves. Crown 8vo, rs. $6 \mathrm{~d}$.

Songs and Verses, Social and Scientific. By an Old Contributor to 'Maga.' Fifth Edition, feap. 8vo, $4 \mathrm{~s}$.

The Greek Anthology. Being Vol. XX. of 'Ancient Classics for Isnglish Readers.' Crown 8vo, 2S. $6 \mathrm{~d}$.

NEW VIRGINIANS, THE. By the Author of 'Estelle Russell,' 'Junia,' \&c. In 2 vols., post $8 \mathrm{vo}$, 18s.

NICHOLSON. A Manual of Zoology, for the Use of Students. With a General Introduction on the Principles of Zoology. By HENRY AL LEYNE NICHOLSON, M.D., F.R.S.E., F.G.S., \&c., Professor of Natural History in the University of Aberdeen. Sixth Edition, revised and enlarged. Crown 8vo, pp. 866, with 452 Engravings on Wood, $14 \mathrm{~s}$.

Text-Book of Zoology, for the Use of Schools. Third Edition, enlarged. Crown 8vo, with 225 Engravings on Wood, 6s.

Introductory Text-Book of Zoology, for the Use of Junior Classes. Third Edition, revised and enlarged, with 136 Engravings, $3 \mathrm{~s}$.

Outlines of Natural History, for Beginners ; being Descriptions of a Progressive Series of Zoological Types. Second Edition, with Engravings, 1s. 6d.

A Manual of Palæontology, for the Use of Students. With a General Introduction on the Principles of Palæontology. Second Edition. Revised and greatly enlarged. 2 vols. 8vo, with 722 Engravings, $£ 2$, 2s.

The Ancient Life-History of the Earth. An Outline of the Principles and Leading Facts of Palæontological Science. Crown 8vo, with numerous Engravings, 1os. 6d.

On the "Tabulate Corals" of the Palæozoic Period, with Critical Descriptions of Illustrative Species. Illustrated with 15 Lithograph Plates and numerous Engravings. Super-royal 8vo, 21s.

On the Structure and Affinities of the Genus Monticulipora and its Sub-Genera, with Critical Descriptions of Illustrative Species. Illustrated with numerous Engravings on wood and lithographed Plates. Superroyal $8 \mathrm{vo}$, $18 \mathrm{~s}$.

Synopsis of the Classification of the Animal Kingdom. In one volume 8vo, with numerous lllustrations.

NICHOLSON. Communion with Heaven, and other Sermons. By the late Maxwell Nicholson, D.D., Minister of St Stephen's, Edinburgh. Crown 8vo, 5s. 6 d.

- Rest in Jesus. Sixth Edition. Fcap, 8vo, 4s. 6d.

OLIPHANT. The Land of Gilead. With Excursions in the Lebanon. By Laurence OLjphant, Author of 'Lord Elgin's Mission to China and Japan,' \&c. With Illustrations and Maps. Demy 8vo, 2rs.

The Land of Khemi. Post 8vo, with Illustrations, Ios. 6d. Traits and Travesties; Social and Political. Post 8vo, ros. 6 d.

Piccadilly: A Fragment of Contemporary Biography. With Eight Illustrations by Richard Doyle. Fifth Edition, 4s. 6d. Cheap Edition, in paper cover, $2 \mathrm{~s} .6 \mathrm{~d}$.

OLIPHANT. Historical Sketches of the Reign of George Second. By Mrs OLiphant. Third Edition, $6 \mathrm{~s}$.

The Story of Valentine; and his Brother. 5s., cloth.

- Katie Stewart. 2s. 6d. 
OLIPHANT. Salem Chapel. 2s. 6d., cloth.

- The Perpetual Curate. 2s. 6d., cloth.

Miss Marjoribanks. 2s. 6d., cloth.

The Rector, and the Doctor's Family. Is. 6d., cloth.

John : A Love Story. 2s. 6d., cloth.

OSBORN. Narratives of Voyage and Adventure. By Admiral Sherard Osborn, C.B. 3 vols. crown 8 vo, 12 s.

OSSIAN. The Poems of Ossian in the Original Gaelic. With a Literal Translation into English, and a Dissertation on the Authenticity of the Poems. By the Rev. ARChIBALD Clark. 2 vols. imperial $8 \mathrm{vo}$, $£$ I, Irs. $6 \mathrm{~d}$.

OSWALD. By Fell and Fjord; or, Scenes and Studies in Iceland. By E. J. OswaLd. One Volume, post 8vo, with Illustrations. [In the Press.

PAGE. Introductory Text-Book of Geology. By David PaGe, LL.D., Professor of Geology in the Durham University of Physical Science, Newcastle. With Engravings on Wood and Glossarial Index. Eleventh Edition, 2s. 6d.

_ Advanced Text-Book of Geology, Descriptive and Industrial. With Engravings, and Glossary of Scientific Terms. Sixth Edition, revised and enlarged, 7s. 6d.

Geology for General Readers. A Series of Popular Sketches in Geology and Paleontology. Third Edition, enlarged, 6s.

Chips and Chapters. A Book for Amateurs and Young Geologists. 58.

The Past and Present Life of the Globe. With numerous tllustrations. Crown 8 vo, $6 \mathrm{~s}$.

The Crust of the Earth: A Handy Outline of Geology. Sixth Edition, rs.

Economic Geology ; or, Geology in its relation to the Arts and Manufactures. With Engravings, and Coloured Map of the British Islands. Crown 8v0, 78. 6d.

Introductory Text-Book of Physical Geography. With Sketch-Maps and Illustrations. Edited by CHARLES LAPWORTH, F. G.S., \&c., Professor of Geology and Mineralogy in the Mason Science College, Birmingham. roth Edition, 28. 6d.

Advanced Text-Book of Physical Geography. Second Edition. With Engravings. 5s.

PAGET. Paradoxes and Puzzles: Historical, Judicial, and Literary. Now for the first time published in Collected Form. By JoHN PAGET, Barrister-at-Law. $870,128$.

PATON. Spindrift. By Sir J. Noer Paton. Fcap., cloth, 5 s.

- Poems by a Painter. Fcap., cloth, $5 \mathrm{~s}$.

PATTERSON. Essays in History and Art. By R. H. Patterson. 8vo, 12s.

PAUL. History of the Royal Company of Archers, the Queen's Body-Guard for Scotland. By JAMES BALFOUR PAUL, Advocate of the Scottish Bar. Crown 4to, with Portraits and other Illustrations. $£ 2,28$.

PAUL. Analysis and Critical Interpretation of the Hebrew Text of the Book of Genesis. Preceded by a Hebrew Grammar, and Dissertations on the Genuineness of the Pentateuch, and on the Structure of the Hebrew Language. By the Rev. WrLliaM PAVL, A.M. 8vo, 18s.

PETTIGREW. The Handy Book of Bees, and their Profitable Management. By A. PETriGrew. Fourth Edition, Enlarged, with Engravings. Crown 8 vo, 3 s. $6 \mathrm{~d}$. 
PHillimore. Uncle Z. By Greville Phillimore, Rector of Henley-on-Thames. Crown 8vo, 78. 6d.

PHILOSOPHICAL CLASSICS FOR ENGLISH READERS. Companion Series to Ancient and Foreign Classics for English Readers. Edited by WrlliaM KNight, LL. D., Professor of Moral Philosophy, University of St Andrews. In crown 8vo volumes, with portraits, price $3^{\mathrm{s}}$. $6 \mathrm{~d}$.

1. Descartes. By Professor Mahaffy, Dublin.

2. Butcer. By the Rev. W. Lucas Collins, M.A., Honorary Canon of Peterborough.

3. Berkelex, By Professor A. Campbell Fraser, Edinburgh.

4. Fichte. By Professor Adamson, Owens College, Manchester.

5. Kant. By William Wallace, M.A., LL.D., Merton College, Oxford.

POLLOK. The Course of Time: A Poem. By RoBert Pollok, A.M. Small feap. 8vo, cloth gilt, 2s. 6d. The Cottage Edition, $32 \mathrm{mo}$, sewed, 8d. The Same, cloth, gilt edges, rs. 6 d. Another Edition, with Illustrations by Birket Foster and others, fcap., gilt cloth, 38. 6d., or with edges gilt, 48.

PORT ROYAL LOGIC. Translated from the French : with Introduction, Notes, and Appendix. By Thomas Spencrr Baynes, LL. D., Professor in the University of St Andrews. Eighth Edition, r2mo, 48.

POST-MORTEM. Third Edition, Is.

BY THE SAME AUTHOR.

The Autobiography of Thomas Allen. 3 vols. post 8vo, 25s. $6 \mathrm{~d}$.

POTTS AND DARNELL. Aditus Faciliores: An easy Latin Construing Book, with Complete Vocabulary. By A. W. Potrs, M.A., LL.D., Head-Master of the Fettes College, Edinburgh, and sometime Fellow of St John's College, Cambridge; and the Rev. C. DARnel., M.A. Head-Master of Cargilfield Preparatory School, Edinburgh, and late Scholar of Pembroke and Downing Colleges, Cambridge. Seventh Edition, fcap. 8vo, 3s. 6d.

- Aditus Faciliores Graeci. An easy Greek Construing Book, with Complete Vocabulary. Third Edition, fcap. 8vo, 3 s.

PRINGLE. The Live-Stock of the Farm. By Robert O. Pringle. Third Edition, crown 8 vo.

[In the press.

PRIVATE SECRETARY. 3 vols. post $8 \mathrm{vo}, 25 \mathrm{~s} .6 \mathrm{~d}$.

PUBLIC GENERAL STATUTES AFFECTING SCOTLAND, from $x 707$ to 1847 , with Chronological Table and Index. 3 vols. large 8vo, $\epsilon_{3}, 33$.

PUBLIC GENERAL STATUTES AFFECTING SCOTLAND, COLLECTION OF. Published Annually with General Index.

RAMSAY. Rough Recollections of Military Service and Society. By Lieut.-Col. Balcarres D. Wardlaw Ramsay. Two vols. post $8 \mathrm{vo}$.

RANKINE. A Treatise on the Rights and Burdens Incident to the Ownership of Lands and other Heritages in Scotland. By JoHN RANKINE, M.A., Advocate. Large 8vo, 4 os.

REID. A Handy Manual of German Literature. By M. F. REId. For Schools, Civil Service Competitions, and University Local Examinations. Fcap. 8vo, 3s.

REVOLT OF MAN. Post 8vo, 7s. 6d.

ROBERTSON. Orellana, and other Poems. By J. Logie RoBertson. Fcap. 8vo. Printed on hand-made paper. 6s.

Our Holiday Among the Hills. By JAMES and JANET LOGIE ROBBRTSON. Fcap. 8vo, 3s. 6 d.

RUSSELL. The Haigs of Bemersyde. A Family History. By JoHN Rugsecr. Large octavo, with Illustrations. 2 rs. 
RUSTOW. The War for the Rhine Frontier, 1870: Its Political and Military History. By Col. W. Rustow. Translated from the German, by JOHN LAYLAND NEEDHAM, Lieutenant R.M. Artillery. 3 vols. 8vo, with Maps and Plans, $£$ I, ris. 6d.

SANDFORD AND TOWNSEND. The Great Governing Families of England. By J. LANGton SANDFord and Meredith Townsend. 2 vols. 8 vo, 15 s., in extra binding, with richly-gilt cover.

SCHETKY. Ninety Years of Work and Play. Sketches from the Public and Private Career of John Christian Schetky, late Marine Painter in Ordinary to the Queen. By his DaUGHTER. Crown 8vo, $7 \mathrm{~s}$. $6 \mathrm{~d}$.

SCOTCH LOCH FISHING. By "Black Palmer." Crown 8vo, interleaved with blank pages, $4 \mathrm{~S}$.

SCOTTISH NATURALIST, THE. A Quarterly Magazine of Natural History. Edited by F. Buchanan White, M.D., F.L.S. Annual Subscription, free by post, 4 s.

SELLAR. Manual of the Education Acts for Scotland. By Alexander Crayg Sellar, Advocate. Seventh Edition, greatly enlarged, and revised to the present time. $8 \mathrm{vo}, 15 \mathrm{~s}$.

SELLER AND STEPHENS. Physiology at the Farm; in Aid of Rearing and Feeding the Live Stock. By WiLLIAM SELLER, M.D., F.R.S.E., Fellow of the Royal College of Physicians, Edinburgh, formerly Lecturer on Materia Medica and Dietetics; and HenRy STEPHENs, F.R.S.E., Author of 'The Book of the Farm,' \&c. Post 8vo, with Engravings, 168 .

SETON. Memoir of Alexander Seton, Earl of Dunfermline, Seventh President of the Court of Session, and Lord Chancellor of Scotland. By GEORge SETON, M.A. Oxon.; Author of the 'Law and Practice of Heraldry in 'Scotland,' \&c. 'In I vol. 8vo.
[In the Press.

SHADWELL. The Life of Colin Campbell, Lord Clyde. Illustrated by Extracts from his Diary and Correspondence. By LieutenantGeneral SHADWELL, C.B. 2 vols. 8vo. With Portrait, Maps, and Plans. $36 \mathrm{s.}$

SIMPSON. Dogs of other Days: Nelson and Puck. By Eve Blantyre Simpson. Fcap. 8vo, with Illustrations, 4s. 6d.

SMITH. The Pastor as Preacher; or, Preaching in connection with Work in the Parish and the Study; being Lectures delivered at the Universities of Edinburgh, Aberdeen, and Glasgow. By HENRY WALLIS SMrTH, D.D., Minister of Kirknewton and East Calder; one of the Lecturers on Pastoral Theology appointed by the General Assembly of the Church of Scotland. Crown 8 vo, 58 .

SMITH. Italian Irrigation: A Report on the Agricultural Canals of Piedmont and Lombardy, addressed to the Hon. the Directors of the East India Company ; with an Appendix, containing a Sketch of the Irrigation System of Northern and Central India. By Lieut.-Col. R. BAIRD SMITH, F.G.S., Captain, Bengal Engineers. Second Edition, 2 vols. 8vo, with Atlas in folio, 3os.

SMITH. Thorndale; or, The Conflict of Opinions. By WiLliam Sмrтh, Author of 'A Discourse on Ethics,' \&c. A New Edition. Crown 8vo, ros. 6 d.

Gravenhurst; or, Thoughts on Good and Evil. Second Edition, with Memoir of the Anthor. Crown 8vo, 8s.

A Discourse on Ethics of the School of Paley. 8vo, 4s.

Dramas. I. Sir William Crichton. 2. Athelwold. 3. Guidone. $24 \mathrm{mo}$, boards, $3 \mathrm{~s}$.

SOUTHEY. Poetical Works of Caroline Bowles Southey. Fcap. $8 \mathrm{vo}, 5 \mathrm{~s}$.

The Birthday, and other Poems. Second Edition, $5 \mathrm{~s}$.

Chapters on Churchyards. Fcap., 2s. 6 d. 
SPEKE. What led to the Discovery of the Nile Source. Вy Јонм Hanning SPEkE, Captain H,M. Indian Army. 8vo, with Maps, \&ce., 14s.

Journal of the Discovery of the Source of the Nile. By J. H. SPERE, Captain H.M. Indian Army. With a Map of Eastern Equatorial Africa by Captain SPEKE; numerous illustrations, chiefly from Drawings by Captain GraNT; and Portraits, engraved on Steel, of Captains SpEKE and Grant. 8vo. 2rs.

SPROTT. The Worship and Offices of the Church of Scotland; or, the Celebration of Public Worship, the Administration of the Sacraments, and other Divine Otfices, according to the Order of the Church of Scotland. Being Lectures Delivered at the Universities of Aberdeen, Glasgow, St Andrews, and Edinburgh. By George W. Sprotr, D.D., Minister of North Berwick; one of the Lecturers on Pastoral Theology appointed by the General Assembly of the Church of Scotland. Crown 8vo, 6s.

STARFORTH. Villa Residences and Farm Architecture : A Series of Designs. By John STARForTH, Architect. 102 Engravings. Second Edition, medium 4 to, $£_{2}, 17 \mathrm{~s} .6 \mathrm{~d}$.

STATISTICAL ACCOUNT OF SCOTLAND. Complete, with Index, 15 vols. 8vo, £16, 16s.

Each County sold separately, with Title, Index, and Map, neatly bound in cloth, forming a very valuable Manual to the Landowner, the Tenant, the Manufacturer, the Naturalist, the Tourist, \&c.

STEPHENS. The Book of the Farm ; detailing the Labours of the Farmer, Farm-Steward, Ploughman, Shepherd, Hedger, Farm-Labourer, FieldWorker, and Cattleman. By HeNRY SrePHENS, F.R.S.E. Illustrated with Portraits of Animals painted from the life; and with 557 Engravings on Wood, representing the principal Field Operations, Implements, and Animals treated of in the Work. A New and Revised Edition, the third, in great part Rewritten. 2 vols. large $8 \mathrm{vo}, £_{2}$, ros.

- The Book of Farm-Buildings; their Arrangement and Construction. By HenRy Stephens, F.R.S.E., Author of 'The Book of the
Farm;' and RoBert Scotr Burn. Illustrated with ro45 Plates and Engravings. Large 8vo, uniform with 'The Book of the Farm,' \&c. $£ \mathrm{x}$, ris. 6d. The Book of Farm Implements and Machines. By J. Suight and R. Scott Burn, Engineers. Edited by Henry Stephens. Large 8 vo, uniform with 'The Book of the Farm,' $£ 2$, 2s.

Catechism of Practical Agriculture. With Engravings. Is.

STEWART. Advice to Purchasers of Horses. By John Stewart, V.S. Author of 'Stable Economy.' 2s. 6d.

Stable Economy. A Treatise on the Management of Horses in relation to Stabling, Grooming, Feeding, Watering, and Working. Seventh Edition, fcap. 8vo, 6s. 6d.

STIRLING. Missing Proofs : a Pembrokeshire Tale. By M. C. Stirisva, Author of 'The Grahams of Invermoy.' 2 vols. crown 8vo, $17 \mathrm{~s}$.

The Minister's Son; or, Home with Honours. 3 vols. post 8vo.

[In the Press.

STORMONTH. Etymological and Pronouncing Dictionary of the English Language. Including a very Copious Selection of Scientific Terms. For Use in Schools and Colleges, and as a Book of General Reference. By the Rev. JAMEs Stormonth. The Pronunciation carefully Revised by the Rev. P. H. Phelp, M.A. Cantab. Sixth Edition, with enlarged Supplement, containing many words not to be found in any other Dictionary. Crown 8vo, pp. 800 . $7 \mathrm{~s} .6 \mathrm{~d}$.

The School Etymological Dictionary and Word-Book. Combining the advantages of an ordinary pronouncing School Dictionary and an Etymological Spelling-book. Fcap. 8vo, pp. 254. 2S.

STORY. Graffiti D'Italia. By W. W. SToRY, Author of 'Roba di Roma.' Second Edition, fcap. 8vo, 7s. 6d. 
STORY. Nero; A Historical Play. Fcap. 8vo, 6s.

- Vallombrosa. Post 8vo, $5 \mathrm{~s}$.

STRICKLAND. Lives of the Queens of Scotland, and English Princesses connected with the Regal Succession of Great Britain. By AGNes STRICKLAND. With Portraits and Historical Vignettes. 8 vols. post $8 \mathrm{vo}$, $£_{4}, 4 \mathrm{~s}$.

STURGIS. John-a-Dreams. A Tale. By Julian Sturgis. New Edition, crown 8vo, 3s. 6 d.

Little Comedies, Old and New. Crown 8vo, 7s. 6d.

Dick's Wandering. 3 vols., post $8 \mathrm{vo}, 25 \mathrm{~s} .6 \mathrm{~d}$.

SUTHERLAND. Handbook of Hardy Herbaceous and Alpine Flowers, for general Garden Decoration. Containing Descriptions, in Plain Language, of upwards of 1000 Species of Ornamental Hardy Perennial and Alpine Plants, adapted to all classes of Flower-Gardens, Rockwork, and Waters; along with Concise and Plain Instructions for their Propagation and Culture. By Wrlliam Sutherla ND, Gardener to the Earl of Minto; formerly Manager of the Herbaceous Department at Kew. Crown 8vo, 7s. 6d.

TAYLOR. Destruction and Reconstruction: Personal Experiences of the Late War in the United States. By RICBARD TAYLOR, LieutenantGeneral in the Confederate Army. 8vo, ros. 6d.

TAYLOR. The Story of My Life. By the late Colonel Meadows TAYLOR, Author of 'The Confessions of a Thug,' \&c. \&c. Edited by his Daughter. New and cheaper Edition, being the Fourth. Crown 8vo, 6s.

THOLUCK. Hours of Christian Devotion. Translated from the German of A. Tholuck, D. D., Professor of Theology in the University of Halle. By the Rev. Robert Menzirs, D. D. With a Preface written for this Translation by the Author. Second Edition, crown $8 \mathrm{vo}, 7 \mathrm{~s}$. $6 \mathrm{~d}$.

THOMSON. Handy Book of the Flower-Garden : being Practical Directions for the Propagation, Culture, and Arrangement of Plants in FlowerGardens all the year round. Embracing all classes of Gardens, from the largest to the smallest. With Engraved and Coloured Plans, illustrative of the various systems of Grouping in Beds and Borders. By DAvid Tromson, Gardener to his Grace the Duke of Buccleuch, K.G., at Drumlanrig. Third Edition, crown 8 vo, 7s. 6d.

The Handy Book of Fruit-Culture under Glass : being a series of Elaborate Practical Treatises on the Cultivation and Forcing of Pines, Vines, Peaches, Figs, Melons, Strawberries, and Cucumbers. With Engravings of Hothouses, \&c., most suitable for the Cultivation and Forcing of these Fruits. Second Edition. Crown 8vo, with Engravings, 7s. 6d.

THOMSON. A Practical Treatise on the Cultivation of the GrapeVine. By WrLliam Trouson, Tweed Vineyards. Ninth Edition, $8 \mathrm{vo}, 5 \mathrm{~s}$.

TOM CRINGLE'S LOG. A New Edition, with Illustrations. Crown 8vo, cloth gilt, $5 \mathrm{~s}$. Cheap Edition, $2 \mathrm{~s}$.

TRAILL. Recaptured Rhymes. Being a Batch of Political and other Fugitives arrested and brought to Book. By H. D. Trarlu. Crown 8 vo, 5 s.

TRANSACTIONS OF THE HIGHLAND AND AGRICULTURAL SOCIETY OF SCOTLAND. Published annually, price ${ }_{5} \mathrm{~s}$.

TROLlope. The Fixed Period. By Anthony Trollope. 2 vols., fcap. 8vo, 12s.

TULLOCH. Rational Theology and Christian Philosophy in England in the Seventeenth Century. By JоHN TULLOCE, D.D., Principal of St Mary's College in the University of St Andrews; and one of her Majesty's Chaplains in Ordinary in Scotland. Second Edition. 2 vols. $8 \mathrm{vo}, 28 \mathrm{~s}$. 
TULLOCH. Some Facts of Religion and of Life. Sermons Preached before her Majesty the Queen in Scotland, r866-76. Second Edition, crown 8 vo, 7 s. 6 d.

The Christian Doctrine of Sin; being the Croall Lecture for 1876 . Crown $8 v 0,6 \mathrm{~s}$.

Theism. The Witness of Reason and Nature to an AllWise and Beneficent Creator. 8vo, ros. 6d.

TYTLER. The Wonder-Seeker; or, The History of Charles Douglas. By M. Fraser TytLer, Author of 'Tales of the Great and Brave,' \&c. A New Edition. Fcap., 3s. 6d.

VIRGIL. The Aneid of Virgil. Translated in English Blank Verse by G. K. Rickards, M.A., and Lord RAvensworth. 2 vols. fcap. 8vo, ros.

WALFORD. Mr Smith : A Part of his Life. By L. B. WALFord. Cheap Edition, 3s. 6d.

Pauline. Fifth Edition. Crown 8vo, 6s.

Cousins. Cheaper Edition. Crown 8vo, 6s.

- Troublesome Daughters. Cheaper Edition. Crown 8vo, 6s.

- Dick Netherby. Crown 8vo, 7s. 6d.

WARREN'S (SAMUEL) WORKS. People's Edition, 4 vols. crown $8 \mathrm{vo}$, cloth, $18 \mathrm{~s}$. Or separately :-

Diary of a Late Physician. 3s. 6d. Illustrated, crown 8vo, 7s. 6d.

Ten Thousand A-Year. 5s.

Now and Then. The Lily and the Bee. Intellectual and Moral Development of the Present Age. 4s. 6d.

Essays : Critical, Imaginative, and Juridical. $5 \mathrm{~s}$.

WARREN. The Five Books of the Psalms. With Marginal Notes. By Rev. Samuel L. Warren, Rector of Esher, Surrey; late Fellow, Dean, and Divinity Lecturer, Wadham College, Oxford. Crown 8vo, $5 \mathrm{~s}$.

WELLINGTON. Wellington Prize Essays on "the System of Field Mancuvres best adapted for enabling our Troops to meet a Continental Army." Edited by General Sir Edward Bruce HaMLey, K.C.M.G. 8vo, r2s. 6d.

WESTMINSTER ASSEMBLY. Minutes of the Westminster Assembly, while engaged in preparing their Directory for Church Government, Confession of Faith, and Catechisms (November 1644 to March 1649). Printed from Transcripts of the Originals procured by the General Assembly of the Church of Scotland. Edited by the Rev. Alex. T. Mitchell, D.D., Professor of Ecclesiastical History in the University of St Andrews, and the Rev. JонкStruthers, LL.D., Minister of Prestonpans. With a Historical and Critical Introduction by Professor Mitchell. 8vo, $15 \mathrm{~s}$.

WHITE. The Eighteen Christian Centuries. By the Rev. James WHITE, Author of 'The History of France.' Seventh Edition, post 8vo, with Index, $6 \mathrm{~s}$.

History of France, from the Earliest Times. Sixth Thousand, post 8vo, with Index, $6 \mathrm{~s}$. 
WHITE. Archæological Sketches in Scotland-Kintyre and Knapdale. By Captain T. P. WhiтE, R.E., of the Ordnance Survey. With numerous Illustrations. 2 vols. folio, $£_{4}, 4$ s. Vol. I., Kintyre, sold separately, $£ 2,2 \mathrm{~s}$.

WILLS AND GREENE. Drawing-room Dramas for Children. By W. G. Wills and the Hon. Mrs GreENe. Crown 8vo, 6 s.

WILSON. The "Ever-Victorious Army:" A History of the Chinese Campaign under Lieut.-Col. C. G. Gordon, and of the Suppression of the Tai-ping Rebellion. By ANDREW WILSON, F.A.S.L. 8vo, with Maps, 158.

The Abode of Snow: Observations on a Journey from Chinese Tibet to the Indian Caucasus, through the Upper Valleys of the Himalaya. New Edition. Crown 8vo, with Map, ros. 6d.

WILSON. Works of Professor Wilson. Edited by his Son-in-Law, Professor FERrier. 12 vols, crown 8vo, £2, 8s.

- Christopher in his Sporting-Jacket. 2 vols., 8s.

- Isle of Palms, City of the Plague, and other Poems. 49.

- Lights and Shadows of Scottish Life, and other Tales. 4s.

- Essays, Critical and Imaginative. 4 vols., $16 \mathrm{~s}$.

- The Noctes Ambrosianæ. Complete, 4 vols., I4s.

The Comedy of the Noctes Ambrosianæ. By Christopher Nortr. Edited by John Skelton, Advocate. With a Portrait of Professor Wilson and of the Ettrick Shepherd, engraved on Steel. Crown 8vo, 78. 6d.

Homer and his Translators, and the Greek Drama. Crown $8 \mathrm{vo}, 4 \mathrm{~s}$.

WiNGate. Annie Weir, and other Poems. By David Wingate. Feap. 8vo, 5s.

- Lily Neil. A Poem. Crown 8vo, 4s. 6d.

WORSLEY. Poems and Translations. By Philip Stanhope WORSLEr, M.A. Edited by EDWARD Worsley. Second Edition, enlarged. Fcap. 8vo, 6s.

WYLDE. A Dreamer. By Katharine WxLde. In 3 vols., post 8vo, 25s. 6d.

YOUNG. Songs of Béranger done into English Verse. By William Young. New Edition, revised. Fcap. 8vo, 4s. 6d.

YULE. Fortification: for the Use of Officers in the Army, and Readers of Military History. By Col. YULE, Bengal Engineers. 8vo, with numerous Illustrations, ros. $6 \mathrm{~d}$. 


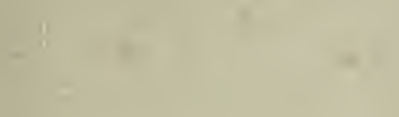


QK Cameron, John

13

C3

Gaelic names of plants

BioMed

\section{PLEASE DO NOT REMOVE}

CARDS OR SLIPS FROM THIS POCKET

UNIVERSITY OF TORONTO LIBRARY 
